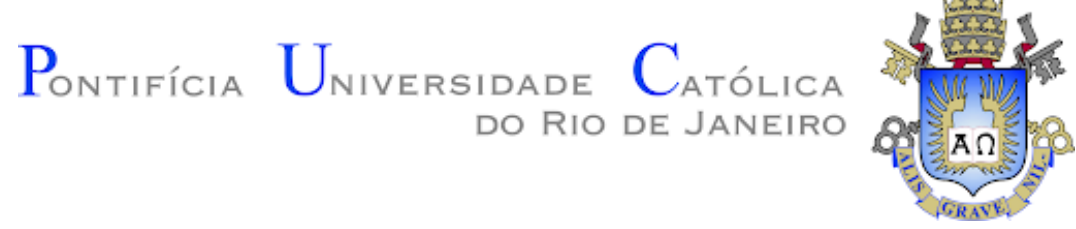

Clara de Melo Araujo

\title{
O YouTube como um lugar possível para se pensar as infâncias
}

Dissertação de Mestrado

Dissertação apresentada como requisito parcial para obtenção do grau de Mestre em Educação pelo Programa de Pós-Graduação em Educação, do Departamento de Educação do Centro de Teologia e Ciências Humanas da PUC-Rio.

Orientadora: Prof. Zena Eisenberg

Rio de Janeiro, fevereiro de 2021 


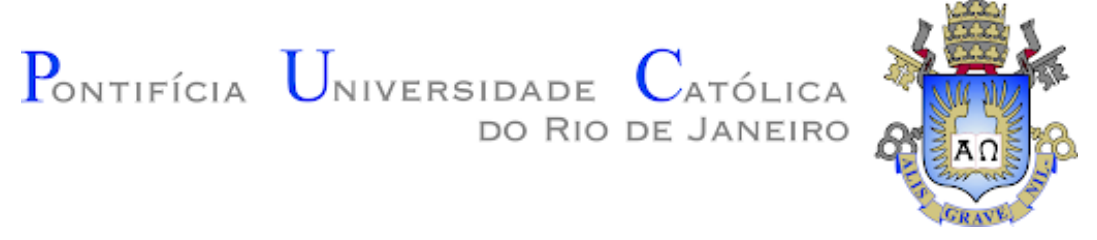

Clara de Melo Araujo

\section{"O YouTube como um lugar possível para se pensar as infâncias"}

Dissertação apresentada como requisito parcial para obtenção do grau de Mestre pelo Programa de Pós-graduação em Educação do Departamento de Educação do Centro de Teologia e Ciências Humanas da PUC-Rio. Aprovada pela Comissão Examinadora abaixo assinada.

Prof ${ }^{a}$. Zena Winona Eisenberg

Orientadora

Departamento de Educação - PUC-Rio

Profa. Maria Cristina Monteiro Pereira de Carvalho

Departamento de Educação - PUC-Rio

Prof ${ }^{a}$. Renata Cristina de Oliveira Tomaz

UFF

Profa. Monah Winograd

Coordenadora Setorial do Centro

de Teologia e Ciências Humanas

PUC-Rio

Rio de Janeiro, fevereiro de 2021 
Todos os direitos reservados. A reprodução, total ou parcial, do trabalho é proibida sem autorização da universidade, da autora e do orientador.

\section{Clara de Melo Araujo}

Mestre em Educação pelo Programa de Pós Graduação da Pontifícia Universidade Católica do Rio de Janeiro, com bolsa do Programa de Bolsas Aluno Nota 10 da Faperj. Pedagoga pela PUC-Rio, formada em 2018. Foi Bolsista de Iniciação Científica do Grupo de Pesquisa Desenvolvimento Humano e Educação (GRUDHE) de 2016 a 2018. Ganhou bolsa pela PUC-Rio para realizar o curso de verão "Experiencing Modern Digital Media Technology" na Birmingham City University, na Inglaterra em 2018. Tem interesse principalmente nos seguintes temas: tecnologia e educação, relação da criança com o YouTube e diversidade no ensino superior. Professora de Educação Infantil.

Ficha Catalográfica

Araujo, Clara de Melo

O YouTube como um lugar possível para se pensar as infâncias / Clara de Melo Araujo ; orientadora: Zena Eisenberg. - 2021.

218 f. : il. color. ; $30 \mathrm{~cm}$

Dissertação (mestrado)-Pontifícia Universidade Católica do Rio de Janeiro, Departamento de Educação, 2021. Inclui bibliografia

1. Educação - Teses. 2. YouTube. 3. Infância. 4. Crianças. 5. Tecnologia. 6. Sociologia da infância. I. Eisenberg, Zena Winona. II. Pontifícia Universidade Católica do Rio de Janeiro. Departamento de Educação. III. Título. 


\section{Agradecimentos}

À minha família que entendeu minha ausência em determinados momentos e que vibrou comigo a cada conquista. Agradeço especialmente à Luísa, minha mãe, que é a pessoa que mais me apoia em todo esse mundo, e ao Luiz, meu vô, que sempre foi minha inspiração e que carinhosamente corrigiu toda esta dissertação.

À Lalinha e Davi, irmã e afilhado, que foram as crianças que me ajudaram a navegar pelo universo do YouTube e alegraram em toda essa trajetória.

Ao Pablo, meu namorado, que me acolheu nos momentos de desespero, me fez rir nos momentos em que mais precisava e me ajudou em cada etapa desta dissertação.

À todas as minhas amigas que me proporcionaram suspiros de alívio e diversão ao longo desses anos. Especialmente à Clarisse, Júlia, Naima, Maria, Clara e Fiona que são essenciais em cada etapa da minha vida. E também Duda e Dani, que me apoiaram desde o comecinho dessa caminhada acadêmica.

A todo mundo que acompanha meu trabalho nas redes sociais. Sou muito grata por termos formado essa rede de apoio e troca tão maravilhosa.

Às crianças incríveis que aceitaram participar desta pesquisa e me encantaram com suas falas e sabedorias, assim como seus responsáveis, que confiaram no processo. E também agradeço à escola que me recebeu de forma tão solícita.

À todas as professoras que compõem minha banca de defesa. Em especial Cristina Carvalho e Rosália Duarte, por me inspirarem desde a graduação e terem contribuído com meu projeto de pesquisa; Silvia Brilhante, por ter me ajudado em toda a etapa quantitativa; e Renata Tomaz por ter aceitado conhecer meu trabalho e fazer parte dessa jornada.

À Zena Eisenberg, que foi a melhor orientadora que eu poderia ter. Acreditou em mim em momentos que nem eu acreditava, me apresentou ao mundo da pesquisa e me fez me apaixonar por tudo isso. 
Aos integrantes do Grudhe, meu grupo de pesquisa querido, que me proporcionou as melhores trocas e aprendizagens de todos esses anos. Cada conselho, cada risada e cada conversa ficarão guardados para sempre comigo.

À toda minha turma de mestrado, que tem pessoas incríveis que estão sempre dispostas a ajudar. Em especial, à Manu e Grazi, com quem compartilhei de pertinho todas as alegrias e desesperos dessa trajetória.

A todo o Departamento de Educação da PUC-Rio, que me acolheu tão bem desde que escolhi a Pedagogia. Profissionais e pessoas incríveis que levarei pra toda minha vida.

Ao CNPQ e à FAPERJ pelas bolsas de incentivo durante a realização do curso que me permitiram ter dedicação exclusiva e aproveitar ao máximo essa jornada.

O presente trabalho foi realizado com apoio da Coordenação de Aperfeiçoamento de Pessoal de Nível Superior - Brasil (CAPES) - Código de Financiamento 001. 


\section{Resumo}

ARAUJO, Clara de Melo. EISENBERG, Zena. O YouTube como um lugar possível para se pensar as infâncias. Rio de Janeiro, 2021. 215p. Dissertação de Mestrado - Departamento de Educação, Pontifícia Universidade Católica do Rio de Janeiro.

Atualmente, muito se fala sobre o uso do YouTube pelas crianças e as influências que youtubers podem ter em suas vidas, mas menos se discute academicamente. A presente pesquisa teve como objetivo conhecer os conteúdos a que as crianças assistem no YouTube e discutir de que forma eles nos permitem pensarmos as infâncias atuais. Utilizaram-se métodos mistos, que consistiram em duas etapas: um levantamento respondido por 344 crianças e entrevistas semiestruturadas coletivas e individuais com 30 crianças. Os participantes tinham de 8 a 10 anos de idade e pertenciam a diferentes grupos sociais no município do Rio de Janeiro. Os dados foram analisados levando em consideração as variáveis de gênero e nível socioeconômico e utilizou-se o método de Análise Temática para olhar as entrevistas. Os achados apontam para uma preferência das crianças pelos vídeos engraçados, de desafios e trollagens - todos com fortes aspectos lúdicos. Constata-se que as culturas infantis estão presentes nos conteúdos a que as crianças assistem e nos usos que fazem do YouTube. Elas assistem aos vídeos para se divertirem, compartilham com seus pares suas preferências e veem os youtubers como pessoas muito diferente delas. As crianças constroem hipóteses ricas sobre o funcionamento da plataforma, se apropriando de formas únicas e mostrando um olhar crítico aos conteúdos a que assistem. Ressalta-se a importância de incluir as crianças nas conversas sobre o YouTube, entendendo o quão apropriadas elas estão desse espaço. Assim pode-se pensar em uma educação midiática e produção de conteúdos que levem a infância em consideração.

\section{Palavras-chave:}

YouTube, Infância, Crianças, Tecnologia, Sociologia da Infância 


\section{Abstract}

ARAUJO, Clara de Melo. EISENBERG, Zena Winona. YouTube as a possible place to think about childhoods. Rio de Janeiro, 2021. 215p. Dissertação de Mestrado - Departamento de Educação, Pontifícia Universidade Católica do Rio de Janeiro.

Lately, much is said about the use of YouTube by children and the influences that youtubers can have on their lives, but little is discussed about it academically. This research aimed to investigate the content that children watch on YouTube, and to discuss how that material allows us to think about different childhoods. Mixed methods were used, which consisted of two stages: a survey answered by 344 children and semi-structured collective and individual interviews with 30 children. The participants were 8 to 10 years old and belonged to different social classes in the city of Rio de Janeiro. The data were analyzed considering the variables of gender and social group. Thematic analysis method was used to look at the interviews. The findings point to children's preference for funny videos, challenges and trolling videos - all with strong playful aspects. It appears that kids' cultures are present in the content that children watch and in the uses that they make of YouTube. They watch videos for fun, share their preferences with their peers, and see youtubers as very different from them. Children build rich hypotheses about how the platform works, appropriating themselves in unique ways and showing a critical look at the content they watch. The importance of including children in conversations about YouTube is emphasized, considering their appropriation of this space. Thus, one can think about media education and content production that take childhood(s) into account.

\section{Keywords:}

YouTube, Childhood, Children, Technology, The Sociology of Childhood 


\section{Sumário}

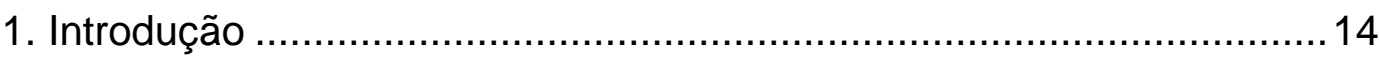

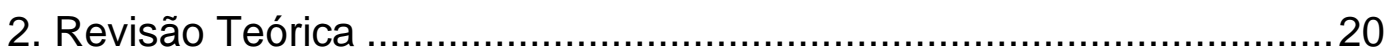

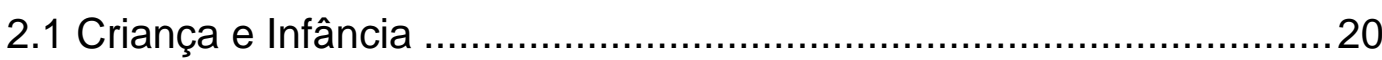

2.1.1 Cultura de pares e culturas infantis ...........................................24

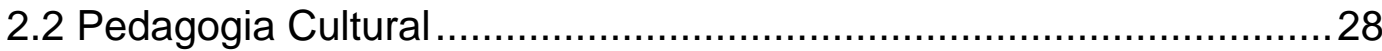

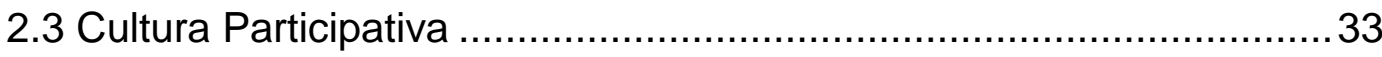

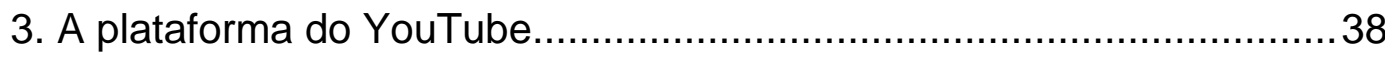

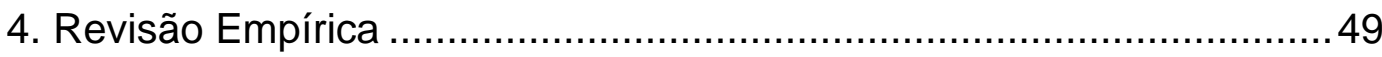

4.1 Os estudos sobre as crianças e a televisão …………………......... 49

4.2 Os estudos sobre as crianças e os conteúdos online ........................56

4.3 Os estudos sobre as crianças e o YouTube ........................................63

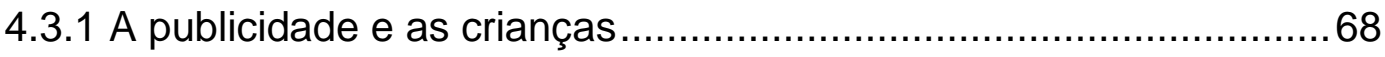

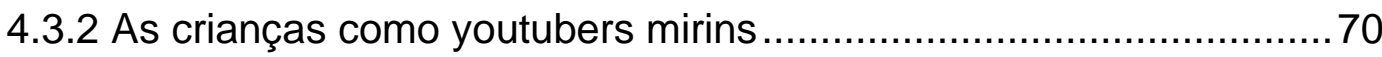

4.3.3 As crianças e os conteúdos do YouTube .....................................76

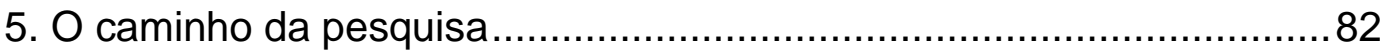

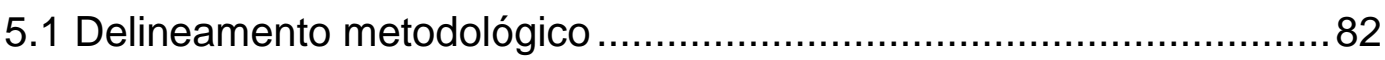

5.2 Etapa I - Levantamento das preferências das crianças ........................83

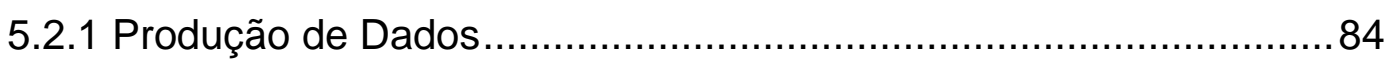

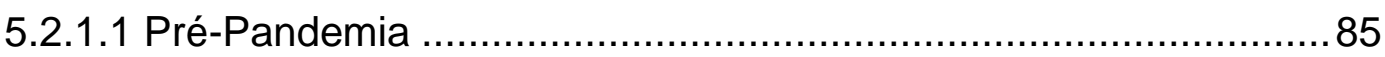

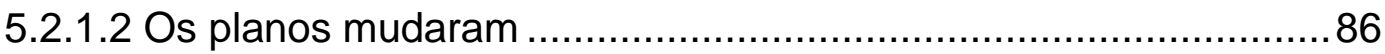

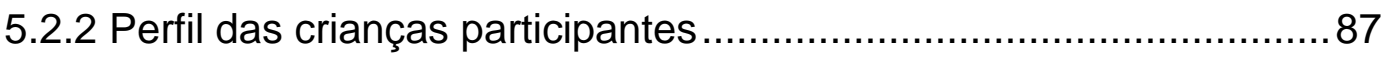

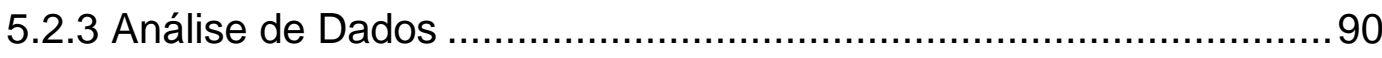

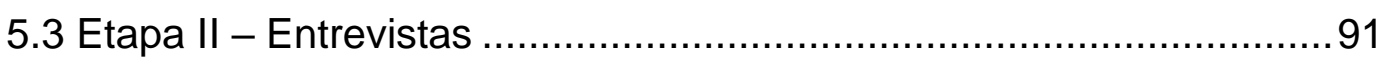

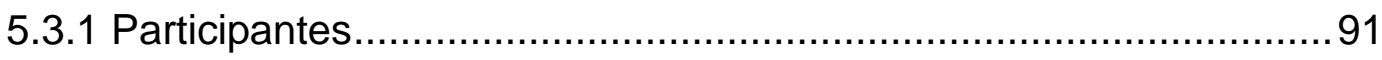

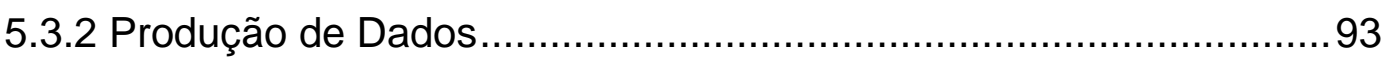

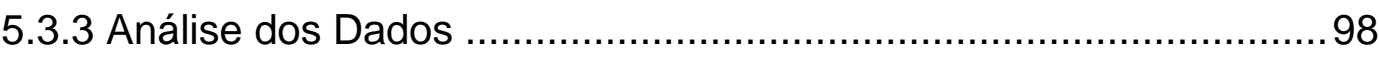




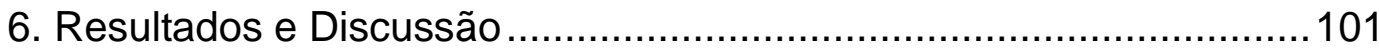

6.1 O que as crianças mais gostam de assistir no YouTube? .................101

6.1.1 Os tipos de vídeos preferidos pelas crianças ................................ 102

6.1.2 Os canais preferidos das crianças ...............................................114

6.2 A Plataforma do YouTube e as Crianças ........................................124

6.2.1 O Uso e a Navegação das Crianças ............................................125

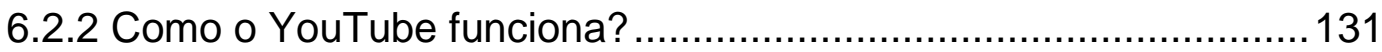

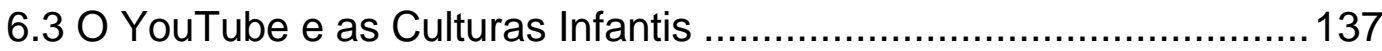

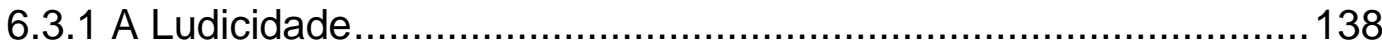

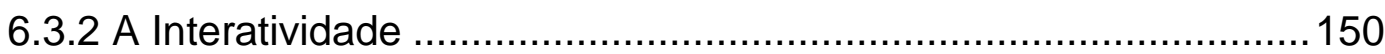

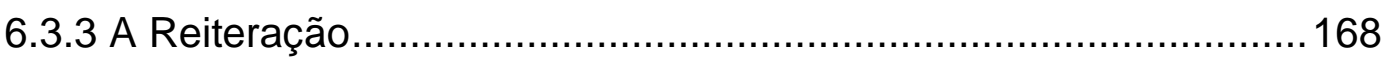

6.3.4 Do que as crianças não gostam no YouTube? ............................. 181

6.3.5 "Vocês gostariam de ser youtubers?"............................................186

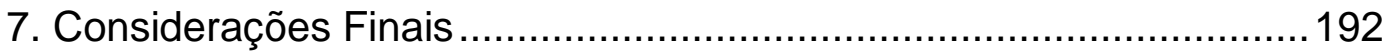

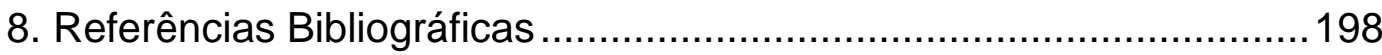

9. Apêndices

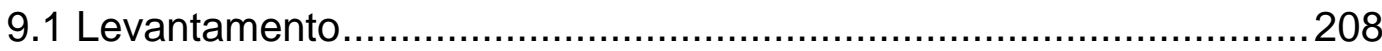

9.2 Convite divulgado nas redes sociais para levantamento...................209

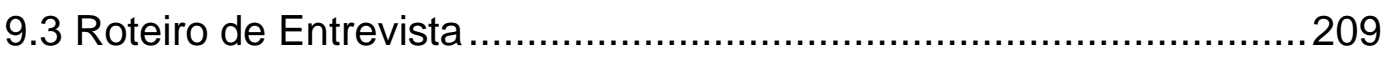

9.4 Convite divulgado nas redes sociais para entrevista........................211

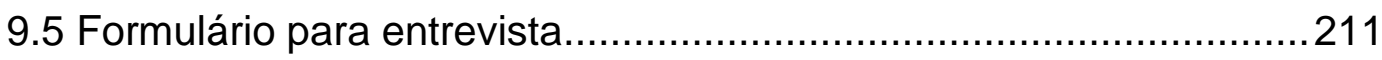

9.6 Termo de Consentimento Livre e Esclarecido ...................................212

9.7 Termo de Assentimento Livre e Esclarecido ..................................215

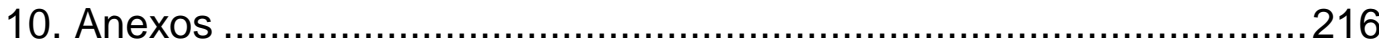

10.1 Parecer da Secretaria Municipal de Educação do Rio de Janeiro..216

10.2 Parecer da Câmara de Ética em Pesquisa da PUC-Rio..................218 


\section{Lista de Figuras}

Figura 1 - Possibilidades de interação com vídeo ....................................41

Figura 2 - Comentário relevante........................................................... 41

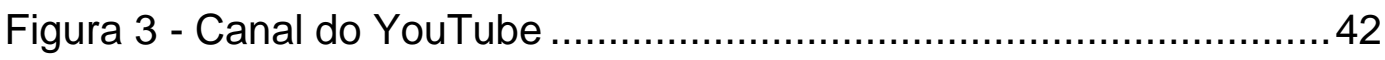

Figura 4 - Qualificação para verificação de canal...................................42

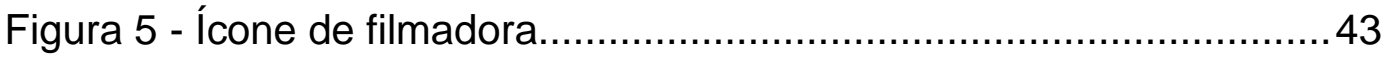

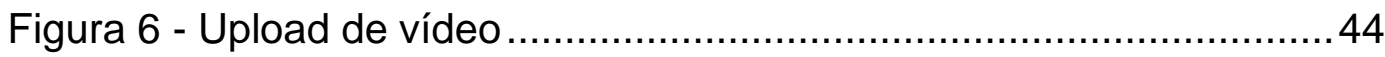

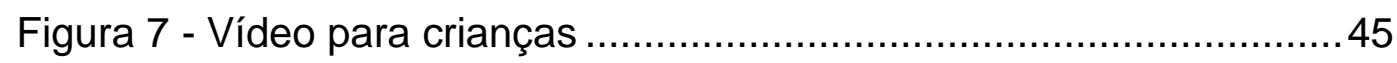

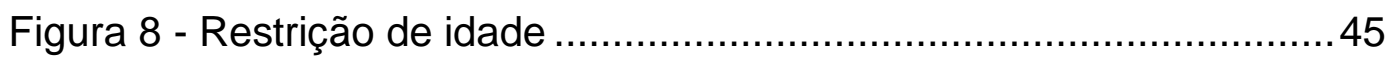

Figura 9 - Penalização de criadores de conteúdos ................................47

Figura 10 - Mapa temático das categorias de análise .............................99 


\section{Lista de Tabelas}

Tabela 1 - Distribuição de crianças por turma ........................................ 85

Tabela 2 - Perfil das crianças participantes......................................... 88

Tabela 3 - Qui-Quadrado por gênero ……………......................... 107

Tabela 4 - Qui-Quadrado por idade...................................................111 


\section{Lista de Quadros}

Quadro 1 - Quadro de levantamento de textos nas plataformas .............64

Quadro 2 - Quadro de levantamento por tipos de textos.......................65

Quadro 3 - Quadro de levantamento por temática dos textos .................67

Quadro 4 - Quadro de youtubers mirins de maior número de inscritos no

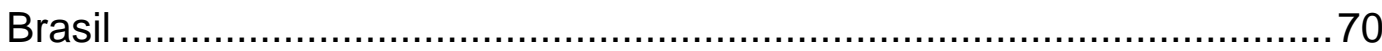

Quadro 5 - Crianças participantes da entrevista ................................92

Quadro 6 - Distribuição de renda das crianças participantes das

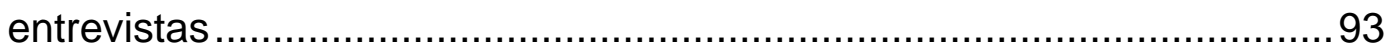

Quadro 7- Perfil das crianças participantes das entrevistas....................96

Quadro 8 - Tipos de vídeos preferidos das crianças ............................ 102

Quadro 9 - Tipos de vídeos preferidos por gênero ............................. 106

Quadro 10 - Tipos de vídeos por gênero e perfil de escola.................... 106

Quadro 11 - Tipos de vídeos preferidos por idade ..............................110

Quadro 12 - Tipos de vídeos preferidos por perfil da escola .................112

Quadro 13 - Canais preferidos das crianças ..................................... 115

Quadro 14 - Perfil dos canais preferidos das crianças .........................116

Quadro 15 - Canais preferidos por gênero .........................................119

Quadro 16 - Canais preferidos por idade ....................................... 121

Quadro 17 - Canais preferidos por perfil da escola ............................. 122 


\section{Lista de Gráficos}

Gráfico 1 - Gráfico de levantamento de publicações por ano.....................66

Gráfico 2 - Perfil das escolas das crianças participantes ..........................89

Gráfico 3 - Gênero das crianças participantes ....................................... 89

Gráfico 4 - Idade das crianças participantes .........................................

Gráfico 5 - Tipos de vídeos com diferenças significativas por gênero....108 


\section{1}

\section{Introdução}

Vivemos em uma época em que as mídias digitais estão cada vez mais presentes na vida de crianças. Apesar de o acesso à internet ainda não estar democratizado, considerando que 4,8 milhões de crianças e adolescentes vivem em casas sem acesso à internet (CETIC.BR, 2020), a grande maioria das crianças estão acessando conteúdos online. A luta pela democratização do acesso anda em paralelo com as preocupações que a sociedade tem em relação ao uso das tecnologias pelos mais jovens.

Para além da preocupação com os possíveis efeitos negativos que o uso de telas pode trazer para as crianças pequenas (DOMINGUES-MONTANARI, 2017), atualmente vemos surgindo uma importante preocupação em relação à forma como os dados dos usuários são coletados pelas grandes indústrias. Tal preocupação foi explorada em documentários recentes, como Privacidade Hackeada (AMER; NOUJAIM, 2019) e Dilema das Redes (JEFF ORLOWSKI, 2020), ainda que as tramas apresentem um teor bastante apocalíptico. Livingstone (2020) aponta para a importância de as pesquisas acadêmicas sobre a temática não caírem no alarmismo, determinismo e pânico, muitas vezes trazidos pelas grandes mídias e pelo senso comum. Quando pensamos nas crianças na internet, devemos sempre pensar em maximizar as oportunidades online enquanto minimizamos os riscos (LIVINGSTONE, 2009), algo que pode ser realizado com a responsabilização do Estado, das empresas e com a presença da mídia-educação nas escolas (BUCKINGHAM, 2019).

Esta pesquisa surge em um momento em que o nosso grupo de pesquisa, GRUDHE (Grupo de Pesquisa Desenvolvimento Humano e Educação), vinha se dedicando a estudar os diferentes aspectos das relações entre as crianças e as tecnologias. Isto, em conjunto com minhas indagações como pedagoga e produtora de conteúdo, nos levaram a querer explorar especificamente a relação com o YouTube 
- que vem se popularizando entre as crianças e gerando novas perguntas e desafios para a temática.

A plataforma, fundada em 2005 e comprada pelo Google um ano depois, chegou à marca dos 98 milhões de usuários no último levantamento realizado (PACETE, 2017). O YouTube é um grande símbolo da era da Cultura da Convergência (JENKINS, 2015), onde as mídias estão cada vez mais se fortalecendo como um meio de Cultura Participativa, na qual os usuários "são convidados a participar ativamente da criação e da circulação de novos conteúdos." (JENKINS, 2015, p. 378). Apesar de a empresa dizer que o YouTube é recomendado para jovens acima dos 13 anos, sabemos que as crianças, além de consumirem conteúdos na plataforma, também estão produzindo vídeos. Com o fenômeno dos youtubers crescendo cada vez mais, surgem novas preocupações acerca dos conteúdos a que as crianças assistem no YouTube. No senso comum, ouvimos muitas famílias reclamarem sobre tais conteúdos, principalmente com o argumento do medo de que tenham acesso a conteúdos inapropriados para sua idade, como palavrão, pornografia ou violência. Também é comum que adultos digam que os youtubers seguidos pelas crianças são influências ruins por ensinarem, por exemplo, pegadinhas de mau gosto, incentivarem o consumismo e até mesmo a não fazer as tarefas da escola (LISAUSKAS, 2018; LUZ, 2018; MATTOS, 2018).

O YouTube, neste trabalho, é visto como uma das muitas instâncias culturais que são pedagógicas, ou seja, que constitui um sistema de significação que também ensina coisas às pessoas (SILVA, 2005), assim como a escola, a igreja, o museu etc. Silva (2005) aponta que, mesmo sem um currículo explícito por trás, as grandes mídias estão formando valores e distribuindo ensinamento às pessoas, mas, muitas vezes, com um grande objetivo de lucro por trás disso. Assim, por mais que enxerguemos o YouTube como uma importante instância na sociedade atual, não podemos deixar de lado seus interesses comerciais, ainda mais quando pensamos nas crianças ali presentes como produtoras e consumidoras.

$\mathrm{Na}$ literatura, ainda são poucos os trabalhos, tanto nacionais como internacionais, que se debruçam especificamente sobre a temática das crianças e o YouTube. O grande foco das produções são os youtubers mirins, ou seja, crianças que têm canais na plataforma. A preocupação é especialmente com relação às questões de publicidade e consumo, como é o caso, por exemplo, nas pesquisas de Oliveira (2019), Marôpo, Sampaio e Miranda (2018), Lemes, Lopes e Rabaiolli (2017), 
Bragaglia e Ferreira (2016) e Papini (2016). Outras pesquisas, como a de Tomaz (2017) e Dalethese (2017) buscam abordar a discussão dos youtubers mirins dando às crianças uma posição de produtoras de sentidos e saberes, olhando para suas criações como uma forma de agência e protagonismo infantil.

São poucos os trabalhos acadêmicos que se dedicam a explorar os conteúdos a que as crianças assistem no YouTube, tanto no âmbito quantitativo quanto no qualitativo. São menos ainda aqueles que utilizam metodologias em que as crianças sejam as protagonistas, ou seja, em que haja espaço para que elas expressem seus pensamentos e opiniões sobre a plataforma. Alguns trabalhos nessa linha que podemos citar são os de Moraes (2017), Satler e Carrijo (2019), Bezerra (2018) e Ribeiro (2020). Ainda assim, a pesquisa de Ribeiro foi a única que contou com uma amostra mais diversificada de crianças e um caminho metodológico mais rigoroso.

Vemos, então, a necessidade de trazer mais as crianças para esse debate, pois aqui acreditamos em uma infância que também é produtora de cultura, que não assiste aos conteúdos de forma passiva, mas que constrói os sentidos e percepções de acordo com suas vivências e interações com outras instâncias. Para apoiar essa concepção de criança e de infância, utilizamos o campo de Sociologia da Infância como base teórica para este trabalho, trazendo principalmente as contribuições de Corsaro (1990; 2002, 2003, 2009a) e Sarmento (1997; 2003a, 2003b).

Assim, podemos nos perguntar: A quais conteúdos as crianças estão assistindo no YouTube e como esses conteúdos nos permitem pensarmos as infâncias atuais? E, mais especificamente: De que forma as culturas infantis, marcadas pelos eixos de ludicidade, reiteração, interatividade e fantasia do real, estão presentes nos conteúdos a que as crianças assistem e na experiência que elas têm com a plataforma do YouTube?

Antes de tentarmos entender o que esses conteúdos significam para as crianças, precisamos conhecê-los de forma mais ampla. Como o YouTube restringe a abertura de conta para adolescentes a partir dos 13 anos, não temos como saber a que as crianças em diferentes idades estão assistindo na plataforma, o que resulta em pensarmos outras formas de ter acesso a essa informação. Nesta pesquisa, optou-se por perguntar diretamente a elas. Esse foi objetivo da primeira etapa, onde fizemos um levantamento com 344 crianças de 8 a 10 anos de escolas particulares que atendem níveis socioeconômicos baixos e altos do município do Rio de Janeiro sobre suas preferências na plataforma. Assim, descobrimos quais são os tipos de 
vídeos e canais preferidos pelas crianças e traçamos hipóteses de como as variáveis de gênero e perfis de escola podem influenciar nessa preferência.

Após essa primeira etapa, foram realizadas entrevistas individuais e coletivas com 30 crianças, quando pudemos explorar mais a fundo os motivos de suas preferências, entender melhor como elas navegam pela plataforma, como escolhem aquilo de que gostam, e quais são suas percepções sobre os vídeos e youtubers a que assistem. A partir dessas respostas e dos achados da primeira etapa, pudemos entender como o YouTube é um lugar possível para pensarmos nas infâncias atuais, que são múltiplas, mas que convergem de certas formas. Optamos por utilizar a palavra "lugar" no título desta dissertação justamente por termos percebido que o YouTube é visto pelas crianças como um ambiente muito familiar, com ricos significados e repleto de afeto e valores, o que, segundo Tuan (1983), são as principais características que transformam um espaço em um lugar.

Dito isso, de uma forma sintetizada, nossos objetivos principais nessa pesquisa, foram:

I) Discutir sobre o lugar do YouTube na sociedade atual e no cotidiano das crianças;

II) Conhecer quais são os tipos de vídeos e canais favoritos das crianças no YouTube e o porquê da preferência;

III) Relacionar os conteúdos favoritos das crianças e os sentidos que atribuem a eles com as culturas da infância;

Essas questões são importantes para potencializarmos o debate e sairmos do senso comum, para que possamos realmente compreender as potências e os limites dos vídeos a que as crianças estão assistindo. Discutir assuntos tão complexos sem dar lugar de fala às crianças é excluí-las mais uma vez de nossa sociedade, ainda mais quando se fala de algo tão presente em suas vidas, como é o YouTube.

É nosso dever como educadores e pedagogos garantir que as crianças tenham acesso a conteúdos positivos e interessantes, sem deixar de considerar a dimensão de entretenimento dos mesmos. Por outro lado, o objetivo não é censurar e/ou proibir aquilo a que assistem, mas sim trazer a discussão para dentro de sala de aula e outras instâncias da sociedade, colaborando, assim, para a formação de um senso crítico.

Isto posto, dividimos esta dissertação em sete capítulos, sendo o primeiro esta introdução. O segundo capítulo é dedicado a apresentar em profundidade os três 
referenciais teóricos utilizados para embasar a pesquisa, a saber: as concepções de criança e infância com base na Sociologia da Infância; os estudos da Pedagogia Cultural e o conceito de Cultura Participativa. Após isso, acrescentamos um capítulo (o terceiro) para tratar exclusivamente das especificidades da plataforma do YouTube, buscando elucidar para o leitor as principais funções da plataforma, assim como o processo por trás da publicação de um vídeo.

Já o quarto capítulo foi dedicado à apresentação da revisão empírica sobre a temática. Primeiramente, apresentamos uma breve revisão dos estudos sobre televisão e infância e sobre conteúdos online e as crianças, buscando contextualizar o leitor no cenário maior. Em seguida, trouxemos um levantamento dos trabalhos específicos sobre as crianças e o YouTube, utilizando as principais bases de dados ${ }^{1}$.

O quinto capítulo trata de todo o caminho da pesquisa, incluindo o percurso metodológico, a escolha por utilizar métodos mistos e os procedimentos de produção e análise de dados. Esta pesquisa foi uma das muitas no mundo todo que teve sua metodologia afetada pela quarentena iniciada com a pandemia do Covid-19, então nesse capítulo explicaremos as adaptações e mudanças que foram realizadas, a fim de adotar procedimentos seguros e possíveis que não comprometessem a qualidade e validade da pesquisa.

No sexto capítulo, dedicamo-nos a apresentar os resultados da pesquisa, assim como discutir tais achados com base na literatura escolhida e nos trabalhos empíricos anteriores a este. Primeiramente, relatamos e discutimos os resultados da primeira etapa da pesquisa, que foi essencialmente quantitativa, e, depois, nos debruçamos sobre os dados qualitativos (segunda etapa da pesquisa), concluindo com uma costura entre ambas análises.

Por último, elaboramos um capítulo de considerações finais que retoma os principais achados do trabalho, assim como aponta para perspectivas futuras em termos acadêmicos, práticos e sociais.

\footnotetext{
${ }^{1}$ Foram utilizadas as plataformas: Google Acadêmico, Scielo, Catálogo de Teses e Dissertações da Capes, Portal da Capes e ERIC.
} 


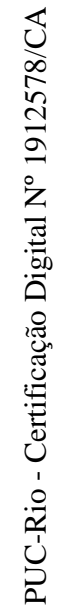




\section{2}

\section{Revisão Teórica}

Neste capítulo, apresentaremos quais foram os referenciais teóricos escolhidos para discutir sobre o lugar do YouTube nas vidas das crianças e sobre os conteúdos a que elas estão assistindo na plataforma. Na primeira seção, apresenta-se a visão de criança e de infância que optamos por adotar nesse trabalho, com base na Sociologia da Infância. Traremos os principais conceitos e abordaremos cada um dos eixos que compõem as culturas infantis.

Após esta primeira parte, será abordado o campo dos Estudos Culturais, mais especificamente, da Pedagogia Cultural, visando situar o trabalho dentro dessa perspectiva. Por último, falaremos especificamente sobre a plataforma do YouTube a partir da visão da mesma como um lugar de promoção de cultura participativa.

\section{1}

\section{Criança e Infância}

As concepções de criança e de infância foram se transformando ao longo dos séculos, e, até os dias de hoje, podemos ver em nossa sociedade diferentes compreensões convergindo. Por esse motivo, é importante deixar claro qual a concepção que escolhemos adotar neste trabalho, que teve como base os autores da Sociologia da Infância.

Entendemos aqui a criança como um sujeito ativo, protagonista de sua própria história e situada em um determinado tempo e espaço. Ariès (1981a) percorre a história para nos mostrar que nem sempre as crianças foram vistas dessa forma. Inclusive, até por volta do século XII, a infância não aparecia representada nas artes medievais, e, quando apareciam crianças nas pinturas, elas eram sempre homens em tamanhos reduzidos, sem expressões particulares desse período da vida (ARIÈS, 
1981a). O autor explica que era como se o sentimento de infância não existisse, pois não havia uma consciência da particularidade infantil. As crianças muito pequenas eram menos consideradas ainda, por conta da alta taxa de mortalidade. Assim, quando elas superavam esse período crítico de sobrevivência, era como se já pudessem ser confundidas com um adulto (ARIÈS, 1981b).

Ariès (1981b) aponta que a partir do século XVI as crianças - das camadas altas da sociedade - começaram a ganhar trajes especiais que as distinguiam dos adultos. A partir de então, começou a surgir um novo sentimento de infância - o de "paparicação". As crianças eram vistas como fonte de distração e relaxamento para os adultos, por conta de sua ingenuidade, gentileza e graça. Entretanto, ao final do século XVI e começo do XVII, já apareciam algumas pessoas de fora do meio familiar que achavam insuportável toda essa atenção que era dada às crianças, surgindo, assim, um novo sentimento que convivia e se contrapunha com aquele da paparicação. Esse novo sentimento veio principalmente de moralistas e educadores e influenciou fortemente as concepções de educação do século XX. O foco eram os interesses psicológicos e a preocupação moral, visando conhecer a infância e entrar na mente das crianças para então poder corrigi-las nas suas imperfeições, torná-las racionais e adaptá-las ao mundo real (ARIÈS, 1981b).

Apesar de esses sentimentos de infância terem surgido há séculos, eles ainda coexistem em nossa sociedade. Pinto (1999) ressalta como é comum as pessoas irem para um dos dois caminhos: ou da criança como alguém que é incompleto, que carece de competências e poderá vir a ser alguém no futuro, ou da valorização da criança como que ela já é, de suas características e capacidades. A interpretação biológica, e até mesmo a psicológica, algumas vezes, tende a olhar para a criança como ainda incompleta, deficiente, e de uma forma reducionista. A infância e a criança são muitas vezes entendidas como homogêneas e universais, como fases de transição com expectativas já traçadas - o que levava a uma patologização quando essas expectativas não são atendidas (WARTOFSKY, 1999).

Em contraposição a essa interpretação biológica, Wartofsky (1999) propõe uma interpretação histórico-cultural, que entende a infância como uma construção, como um atributo cultural, historicamente situada. $\mathrm{O}$ autor entende a criança como um ser agente, protagonista, com um papel ativo na construção de sua infância. E essa construção é um processo dialético, que inclui as representações que a sociedade tem sobre a criança, as teorias e os discursos, e também as representações que 
as próprias crianças constroem, uma vez que elas não apenas imitam, mas também criam e reinterpretam. Essa concepção de criança e infância vai de encontro com o que Pinto (1999) chama de "dimensões sociais da infância", que leva em consideração os processos sociais, nos quais a infância emerge a partir dessa realidade social e ao mesmo tempo a produz.

Nessa pesquisa, será levada em consideração essa concepção da Sociologia da Infância, expressa principalmente a partir dos trabalhos de Manuel Jacinto Sarmento e William Corsaro. Foram elencados 3 conceitos-chaves para serem discutidos que nos ajudarão a olhar para os dados desta pesquisa a partir perspectiva sociológica. São eles: culturas da infância (SARMENTO, 2003a), cultura de pares (CORSARO, 1997) e reprodução interpretativa (CORSARO, 2009b).

Culturas da infância refere-se à "capacidade das crianças em construírem de forma sistematizada modos de significação do mundo e de acção intencional, que são distintos dos modos adultos de significação e acção" (SARMENTO, 2003a, p. 3). E o termo é no plural justamente para marcar as diferenças de, por exemplo, classe, gênero e raça que existem em cada uma das culturas e que se refletem na produção e sentido das infâncias - que são sociais e históricas. Apesar de as características culturais serem múltiplas e heterogêneas, Sarmento (2003b) argumenta que a condição comum das infâncias é o fato de as crianças serem uma geração dependente de cuidados e que está sob o controle da geração adulta. Para o autor, esse denominador comum faz com que alguns elementos simbólicos e materiais estejam sempre presentes, assinalando o lugar das culturas infantis.

Sarmento (2003b) diferencia as formas culturais que são produzidas para as crianças, muitas vezes por uma indústria que visa o lucro, e aquelas que são produzidas pelas crianças, como os jogos infantis que são transmitidos de gerações para gerações. As primeiras são formas culturais criadas por adultos e direcionadas às crianças, como, por exemplo, literatura infantil, jogos e brinquedos, sites, serviços, festas de aniversário, entre outras (SARMENTO, 2003b). O autor aponta, no entanto, que esses produtos e serviços só conseguem se estabelecer no mercado e se difundir entre as culturas infantis quando são compatíveis com as condições de recepção das crianças, pois são elas, as consumidoras, que vão demonstrar empatia ou não com essas formas culturais. Esses produtos industriais têm suas universalizações explicadas por conta da conformidade com o imaginário infantil, mesmo que 
muitas vezes o valor simbólico de um produto se sobreponha ao potencial lúdico como é o caso da boneca Barbie, por exemplo (SARMENTO, 2003b).

Veremos mais adiante como os estudos mostram, de fato, que as crianças não são receptoras passivas dos produtos industriais e midiáticos, mas que reinterpretam aquilo que está sendo visto. Por isso mesmo, é importante, para a compreensão das culturas infantis, a conjugação da "análise da produção das formas culturais para a infância com a recepção efetiva dessas formas pelas crianças" (SARMENTO, 2003b, p. 7). Por conta da falta de estudos que levam em consideração as vozes das crianças espectadoras de vídeos do YouTube, esse estudo se dedicará à segunda parte dessa conjugação, mais especificamente, aos sentidos que as crianças atribuem aos vídeos a que assistem na plataforma - vistos aqui como importantes produções culturais para a infância.

Outro fator necessário de ser considerado é o de que, atualmente, podemos entender que essas barreiras entre o que é produzido para as crianças e pelas crianças estão cada vez menos delimitadas. Quando pensamos no universo do YouTube, por exemplo, muitas crianças são youtubers mirins, que ao mesmo tempo em que estão produzindo e compartilhando culturas da infância, também ganham dinheiro para fazer propaganda de grandes marcas, contribuindo assim, possivelmente, para um maior consumismo infantil (BRAGAGLIA; FERREIRA, 2016). Mais adiante nesta dissertação, discutiremos de forma mais profunda essa questão, mas é um apontamento importante de já ser levantado.

Sabemos, inclusive, que as mídias e o YouTube não são os únicos fatores importantes para pensarmos as mudanças nas culturas das infâncias contemporâneas. É essencial ressaltar que $30 \%$ da população brasileira ainda não tem acesso à internet em suas casas (LAVADO, 2019). Por outro lado, não podemos deixar de ver a revolução que as novas tecnologias trouxeram para a vida de muitas crianças. Em relação a isso, Sarmento e Barra (2008) trazem que:

As crianças hoje em dia encontram mudanças, operadas por elas ou para elas, que modificaram as condições sociais para a aquisição do "seu" capital cultural e para a construção das suas próprias concepções sobre o mundo. Será necessário que os adultos tentem penetrar neste novo universo da infância, que apesar de ter sido construído por eles, não é do seu domínio. (SARMENTO; BARRA, 2008, p. 7)

Sarmento e Barra (2008) entendem que as crianças aprendem umas com as outras em espaços de partilha comum, e é justamente assim que se estabelece a 
cultura de pares. Discutiremos neste trabalho como podemos entender o YouTube como um desses espaços de partilha comum, de trocas de saberes e experiências entre as crianças, a partir dos vídeos que as mesmas produzem, assistem e compartilham. Entretanto, antes de falarmos especificamente sobre a plataforma do YouTube, precisamos entender um pouco mais as características das culturas infantis e das culturas de pares.

\subsection{1}

\section{Cultura de pares e culturas infantis}

Corsaro (1990) define a cultura de pares como "um conjunto de atividades ou rotinas, artefatos, valores e preocupações que as crianças produzem e partilham na interação com os seus pares." (CORSARO; DONNA, 1990). É por meio dessa convivência e troca que as crianças podem se apropriar e reinventar tudo que existe à sua volta. Ou seja, as crianças não simplesmente imitam o mundo adulto, mas sim o apreendem criativamente, visando produzir suas próprias culturas (CORSARO, 2009a).

Para entendermos melhor essa ideia, é importante trazer o conceito de reprodução interpretativa, também definido por Corsaro. O termo reprodução traz a ideia de que as crianças não internalizam a sociedade e a cultura das quais são membros de uma forma direta e linear, mas também contribuem de forma ativa para sua produção e mudança (CORSARO, 2009a). Já a interpretação aborda o modo como a criança participa e produz a própria cultura de pares, a partir da sua criatividade, ao se apropriar das informações do mundo adulto e buscar significados para suas culturas infantis (CORSARO, 2009a).

Resumidamente, podemos então dizer que "as crianças apreendem criativamente informações do mundo adulto para produzir suas culturas próprias e singulares” (CORSARO, 2009a, p. 31). Como já apontado por Sarmento (2003b), essas culturas são múltiplas no que se refere às variações regionais, de gênero, classe etc, mas possuem um denominador comum que faz com que haja certos aspectos que podem ser considerados universais (CORSARO; DONNA, 1990; CORSARO, 2009a). 
Corsaro e Donna (1990) realizaram uma revisão de estudos empíricos que apontaram para três grandes temas presentes nas culturais infantis: 1) a importância do compartilhamento e de participação social; 2) a tentativa de lidar com confusões, preocupações, medos e conflitos no cotidiano e 3) a resistência e o desafio às regras do mundo adulto e à autoridade. Esses foram aspectos encontrados nas culturas de pares em diferentes lugares do mundo, entre diferentes idades, classes sociais e gêneros. Segundo os autores, as crianças estão, basicamente, querendo ganhar controle sobre suas vidas e dividir esse controle com outras crianças, mesmo que, ao longo dos anos, haja a tendência à necessidade de diferenciação do grupo, principalmente por meio da separação por gênero (CORSARO; DONNA, 1990). A cultura de pares, como já dito anteriormente, é justamente o conjunto de atividades, rotinas, valores e preocupações produzidos e compartilhados entre as crianças que vão ajudá-las a entender o mundo e lidar com suas necessidades e vontades.

Duas brincadeiras, por exemplo, que foram encontradas de diferentes formas nas culturas de pares e que podem ser consideradas aspectos universais dessa cultura são as de aproximação-evitação e as de dramatização de papéis (CORSARO, 2009a). A primeira se configura em torno de as crianças terem que identificar um monstro ou agente ameaçador, se aproximarem dele e depois terem que fugir de seu ataque - aqui no Brasil seriam brincadeiras como "Cabra-Cega", "Polícia e Ladrão" ou outros tipos de "Pique-pega" comuns na infância brasileira. Corsaro (2009a) explica a importância de tais brincadeiras para as crianças:

As crianças produzem coletivamente uma rotina na qual compartilham a acumulação de tensão, a excitação da ameaça, e o alívio e a alegria da fuga. As representações sociais de perigo, mal, desconhecido e outras ambiguidades, que estão se desenvolvendo nas crianças, são mais firmemente apreendidas e controladas. (CORSARO, 2009a, p. 33)

A segunda brincadeira comum nas culturas infantis é a de dramatizações de papéis, também importantes para o desenvolvimento social e emocional das crianças. Corsaro (2009a) explica que essas brincadeiras não podem ser vistas como uma simples imitação dos modelos adultos, mas sim uma apropriação, elaboração e enriquecimento dos mesmos (i.e., reprodução interpretativa). $\mathrm{O}$ autor aponta que essas experiências possibilitam às crianças adquirirem poder, status e controle de modo temporário, assim como possibilita que elas testem e experimentem os diferentes 
papéis sociais, descobrindo como as pessoas das sociedades agem e se relacionam - e, muitas vezes, desconstruindo e desafiando tais papéis impostos.

Sarmento (2003a) aponta também, nessa perspectiva de características universais, para quatro eixos estruturadores das culturas da infância, sendo eles: a interatividade, a ludicidade, a fantasia do real e a reiteração.

A interatividade é representada pelo contato que as crianças têm com as várias realidades do cotidiano, com sua família, seus professores, seus vizinhos e, principalmente, com outras crianças. É a partir dessas experiências e trocas que a criança aprende sobre o mundo, se apropria dele e o reinventa, formando sua identidade pessoal e social (SARMENTO, 2003a). A interatividade é marcada principalmente pela cultura de pares, explicada anteriormente, na qual as crianças se identificam como "amigos" para, juntas, serem companheiras de atividades, compartilharem rituais e brincadeiras, construírem fantasias, representarem cenas do cotidiano, criarem estratégias para contornar as regras adultas e, dessa forma, lidarem com as experiências do mundo (SARMENTO, 2003b). Sarmento (2003b) explica que é a partir dessa interatividade com outras crianças que elas também vão passar por processos de identificação social, com o estabelecimento de fronteiras de inclusão e exclusão em seus grupos de amigos, seja por gênero, por subgrupos etários ou por status - este último mais frequente em crianças mais velhas e adolescentes, segundo Corsaro e Dona (1990).

A ludicidade é outro eixo essencial das culturas infantis, mas não exclusivo delas. Sarmento (2003a) explica que adultos também brincam, pois essa é uma atividade inerente do ser humano, mas não da mesma forma que as crianças. $\mathrm{O}$ autor ressalta que, diferentemente dos adultos, as crianças não separam o "brincar" do “fazer coisas sérias", elas brincam de forma contínua e isso é uma das coisas mais sérias que elas fazem.

Brougère (1998) argumenta a importância de ver o jogo como o lugar de emergência e enriquecimento da cultura lúdica, que seria, antes de tudo "um conjunto de procedimentos que permitem tornar o jogo possível" (BROUGÈRE, 1998, p. 107). Assim, o autor argumenta que as crianças possuem certos elementos, esquemas e referências que lhes permitem jogar e brincar, possibilitando, inclusive, que as crianças interpretem como jogos atividades que não seriam interpretadas dessa forma por adultos. Brougère ressalta que essa cultura lúdica é diversificada de acordo com alguns fatores, como, por exemplo, a cultura "maior" em que a 
criança está inserida, o meio social, a idade e o gênero. A cultura lúdica é construída a partir da brincadeira, e a experiência para essa brincadeira pode ser adquirida a partir da participação nela própria, da observação de outras crianças ou das brincadeiras da televisão e da manipulação dos objetos de jogo (BROUGÈRE, 1998). Essa ideia de ludicidade será importante mais adiante quando formos discutir os conteúdos que as crianças gostam de assistir nos canais do YouTube.

O brincar e a brincadeira estão atrelados a outro fator importante nas culturas da infância: a fantasia do real. A cultura lúdica da infância se expressa muitas vezes a partir do jogo simbólico e a característica de fantasia presente nele vai além da dicotomia realidade-fantasia, em um fazer de conta que é processual e que extrapola as noções de literalidade (SARMENTO, 2003a). Sarmento (2003a) ilustra tal processo trazendo o exemplo da criança que acredita que uma estrela no céu é uma pessoa querida que se foi, ou que imagina uma narrativa a fim de explicar uma falha que cometeu - são tentativas de resistência que fazem frente a situações difíceis de lidar, o que "permite continuar o jogo da vida em condições aceitáveis para a criança" (SARMENTO, 2003a, p. 106).

A não literalidade desse processo se complementa com a não linearidade temporal, caracterizada pela reiteração, pela continuidade de processos que podem ser reinventados, reiniciados e repetidos (SARMENTO, 2003a). Sarmento (2003a) explica que é a partir desse tempo não linear que a criança constrói seus fluxos de ação, de interação com o outro, suas rotinas e suas propostas e rupturas, possibilitando encontrar as ligações entre as brincadeiras passadas que vão se repetir no futuro, mas também que se renovam e incorporam o novo. $\mathrm{O}$ autor completa dizendo que:

O tempo recursivo da infância tanto se exprime no plano sincrónico, com a contínua recriação das mesmas situações e rotinas, como no plano diacrónico, através da transmissão de brincadeiras, jogos e rituais das crianças mais velhas para as crianças mais novas, de modo continuado e incessante, permitindo que seja toda a infância que se reinventa e recria, começando tudo de novo. (SARMENTO, 2003a, p. 18)

Com isso, o autor deixa claro que não há possibilidade de se falar em um possível desaparecimento da infância, como apontado, por exemplo, pelo polêmico livro "O Desaparecimento da Infância” de Neil Postmam (2006). Sarmento (2003a) defende que o lugar da criança é essencialmente o lugar das culturas da infância, 
que é reestruturado e reconfigurado pelas próprias crianças, a partir dos fatores e condições históricas de cada geração.

Neste trabalho, o intuito é considerar todas essas dimensões das culturas infantis para justamente olharmos para o YouTube como um desses lugares contemporâneos em que as crianças estão presentes, tanto como produtoras quanto como consumidoras. Será que os conteúdos dos vídeos a que as crianças gostam de assistir e os sentidos que elas atribuem a eles se distanciam ou se aproximam desses eixos e dimensões que foram apontadas como presentes em todas as culturas infantis? Para discutirmos isso em mais profundidade, precisamos antes entender um pouco mais sobre o YouTube como uma instância pedagógica e como promotor de uma cultura participativa.

\section{2}

\section{Pedagogia Cultural}

O campo chamado de Estudos Culturais teve sua origem na criação do Centro de Estudos Culturais Contemporâneos, na Universidade de Birmingham, na Inglaterra, em 1964. O motivo da fundação do grupo foi questionar o porquê de a cultura - especialmente da literatura britânica - ser acessada apenas por um grupo restrito e privilegiado de pessoas, se distanciando assim da democracia (SILVA, 2005).

Giroux (1994) explica que os estudos culturais podem ser definidos pela:

(...) análise de cultura e poder, particularmente no que diz respeito a mudança de terreno da cultura em direção ao popular, enquanto simultaneamente expande a leitura crítica da produção, recepção, uso e efeitos dos textos populares (...) tais textos são frequentemente tomados como uma parte da tentativa de analisar como as identidades individuais e sociais são mobilizadas, engajadas e transformadas nesse circuito de poder informado pelos problemas de raça, gênero, classe, etnia e outras formações sociais." (GIROUX, 1994, p. 281) (tradução nossa)

Ao longo dos anos, diversas vertentes dos Estudos Culturais foram surgindo ao redor do mundo, mas sempre tendo como foco a análise da cultura, entendida como uma experiência vivida por um grupo social que se configura como campo de luta por significações (SILVA, 2005).

Silva (2005) explica que, em outras palavras, a cultura seria um espaço onde as diferentes camadas, com seus diferentes poderes, vão lutar para que seu modo de vida, seus valores e ideais sejam aqueles prevalentes. Assim, a cultura definiria a 
forma como as pessoas e os grupos devem ser, como devem se comportar e agir. Nessa lógica, não há sentido em estabelecer uma separação rígida entre um saber tradicional, acadêmico e escolar e um conhecimento do cotidiano das pessoas ambos são objetos culturais que expressam significados e lutam para influenciar a sociedade. $\mathrm{O}$ autor aponta que podemos entender que tanto o conhecimento dito científico quanto o popular estabelecem tipos de subjetividade e identidade social.

Esse conceito de cultura, sendo tudo que constitui em um sistema de significações (SILVA, 2005), possibilitou com que fosse possível equiparar a educação a outras instâncias e instituições, como, por exemplo, ao cinema, aos museus, à indústria etc. Atualmente, a internet e os novos meios de comunicação são também fontes de pesquisas dos Estudos Culturais, assim como a plataforma do YouTube.

Silva (2005) aponta que o interessante é perceber que essas outras instâncias também podem ser consideradas pedagógicas, uma vez que elas também estão ensinando coisas às pessoas. $\mathrm{O}$ autor defende que, assim como a pedagogia pode ser uma forma cultural, a cultura geral também é pedagogia. Nessa perspectiva, é possível afirmar que essas instituições possuem, assim como a escola, um currículo. Esse currículo, por sua vez, pode ser explícito, como é o caso de programas educativos, por exemplo, ou não explícito, quando não há o objetivo declarado de ensinar algo. Entretanto, sabemos que, mesmo sem esse objetivo, todas as manifestações culturais, instituições e instâncias ensinam alguma coisa e geram conhecimento em algum momento. E, mais do que transmitir informações, desse ponto de vista de uma Pedagogia Cultural, essas instâncias estão influenciando maneiras de se comportar e de viver.

Fischer (1997) entende os produtos midiáticos como jornais, novelas e desenhos animados como uma materialidade discursiva, como geradores e veiculadores de um discurso, uma tecnologia de comunicação e informação. Entretanto, a autora aponta que a mídia não é apenas veiculadora e transmissora, mas também produtora de saber e significados, contribuindo para a formação do sujeito - e por isso pode ser considerada pedagógica.

A questão importante é que, apesar de agora existir essa equiparação entre as pedagogias e instâncias, a luta de poder baseada nos recursos financeiros faz com que haja uma grande diferença entre a pedagogia escolar e as pedagogias mais amplas: os objetivos comerciais por trás (SILVA, 2005). Grandes empresas e indústrias sempre visam lucro, e, por isso, fazem de tudo para deixar aquilo que estão 
apresentando o mais sedutor possível - focando principalmente nas crianças. O famoso documentário "Criança: A Alma do Negócio" (RENNER; NISTI, 2007) nos mostra o que há por trás das cortinas do mundo do marketing, as técnicas e psicologias aplicadas a partir de estudos feitos para que as crianças desejem consumir determinado produto.

Silva (2005) explica que é um enorme mercado visando lucro que está disposto a fazer de tudo para que seus ideais prevaleçam. Nesse sentido é que será abordada, mais adiante, a questão das publicidades nos vídeos infantis. É uma temática extremamente importante e relevante merecendo um estudo, não apenas no campo da Comunicação, como acontece atualmente, mas também da Educação. O foco nos canais do YouTube ainda apresentará uma variável importante: muitas das vezes são crianças falando com outras crianças. Dessa forma, as crianças são as protagonistas desse processo cultural, mas que não deixa de estar permeado também por grandes marcas que pouco se preocupam com a infância da mesma forma que nós, educadores, nos preocupamos.

Giroux (1994) ressalta essa importância de que os teóricos da Educação também se interessem e se preocupem com os Estudos Culturais, assim como, inversamente, aponta a contribuição fundamental que a Pedagogia tem para esse campo de estudo. O autor enfatiza a necessidade de nos apropriarmos dos Estudos Culturais, principalmente para entendermos de que forma o conhecimento é produzido nessas instâncias fora da escola.

Henry Giroux foi um dos pioneiros a associar a educação aos Estudos Culturais de forma tão clara, sendo fundamental para a construção do conceito que hoje chamamos de Pedagogias Culturais (ANDRADE; COSTA, 2017). Andrade e Costa (2017) fizeram um estudo buscando delinear esse conceito, problematizando e dialogando sobre como ele é utilizado, à luz das teorizações que diversos autores fizeram em cima dele.

As autoras encontraram que esse conceito foi visto pela primeira vez no livro de David Trend Cultural Pedagogy: arts, education, politic (Pedagogia cultural: artes, educação, políticas), em 1992, apesar de não com o sentido exato que é adotado nos dias de hoje. É interessante ressaltar que esse livro se encontra na coleção Critical Studies in Education and Culture Series, organizada por Henry Giroux e Paulo Freire, mostrando a importância que a temática assumiu nas últimas décadas. Andrade e Costa (2017) apontam, no entanto, que foram as pesquisas dos norte- 
americanos Shirley Steinberg e Joe Kincheloe que fizeram o conceito de Pedagogia Cultural se consolidar no campo acadêmico, inclusive aqui no Brasil.

No livro Kinderculture: The Corporate construction of childhood (2011), publicado pela primeira vez em 1997, Steinberg e Kincheloe discutem diversas temáticas abordando como a cultura do consumismo e da propaganda molda a infância das crianças. Na edição mais recente, de 2011, podemos encontrar temáticas como a febre dos filmes de vampiros como Crepúsculo e o fenômeno da série Hannah Montana. Os autores (2011) argumentam que todos esses artefatos midiáticos são pedagogias culturais que estão criando gerações de crianças com infâncias pré-fabricadas. Seguindo essa mesma visão crítica, Giroux (1999) também se dedicou durante anos a analisar essas pedagogias da mídia, tendo como foco principal os filmes da Disney. Abordarei a seguir algumas contribuições teóricas que esses estudos trouxeram.

Giroux (1999) aponta como os contos da Disney, por exemplo, influenciam as crianças de forma semelhante a outras instâncias como família, escola e igreja. Os filmes infantis trazem uma série de valores, papéis sociais e ideais que são tão legítimos quanto outros com que a criança tem contato, o que os torna também uma fonte de aprendizagem. $\mathrm{O}$ autor aponta que um dos motivos de os filmes serem tão fascinantes para as crianças é justamente por apresentarem um mundo de fantasia, imaginação e diversão. A escola, muitas vezes vista como chata e maçante, seria o contrário desse universo tecnológico, cheio de cores e histórias de aventura-e com um grande apelo comercial.

Giroux acredita que a Disney é uma das primeiras instituições que constroem as culturas infantis nos Estados Unidos, e, por isso, defende que é necessário que as famílias e escolas debatam sobre o impacto desses filmes nas vidas das crianças. Ressalta que é importante não subestimar ou se enganar pelo caráter de diversão e inocência que a empresa carrega, pois, por trás disso, há uma transmissão de valores para as crianças.

O autor alerta, entretanto, que o caminho não é condenar a Disney como uma empresa que apenas propaga ideologias e conservadorismo sob o pretexto do entretenimento. É importante reconhecer que os filmes trazem um mundo fantástico para as crianças, com músicas atrativas, personagens impactantes e muita diversão, dando aos pequenos algo que corresponde aos seus desejos e que produz grandes 
significados para a cultura infantil. Entretanto, é necessário ter a visão crítica ao mesmo tempo em que se reconhece isso. Em relação a isso, o autor aponta que:

Se educadores e outros profissionais culturais querem incluir a cultura das crianças como um importante lugar de contestação e luta, então é imperativo analisar como os filmes animados da Disney influenciam a forma com que a paisagem cultural americana é imaginada (...) Isso é particularmente importante pois os filmes animados da Disney provocam e dão substância à imaginação, aos desejos, papéis e sonhos das crianças, enquanto simultaneamente sedimentam afeto e significado (GIROUX, 1999, p. 91) (tradução nossa)

Assim, seria necessário discutir tais filmes como qualquer outra esfera pública de significantes culturais, analisando esses ideais e valores que são transmitidos, mas também discutindo sobre como esses filmes narram a cultura infantil.

O contato com os trabalhos de Giroux, Steinberg e Kincheloe pode nos levar a questionar a noção de construção e transmissão de valores, pois, por vezes, parece que tais autores apresentam as crianças em uma perspectiva um pouco passiva nesse processo de recepção do conteúdo. Pouco se discute em seus trabalhos sobre as percepções que as próprias crianças têm ou poderiam ter sobre os filmes. Por se embasar na teoria crítica, os três autores operam muito a partir da visão de como essa produção cultural pode alienar ou oprimir os sujeitos, diferentemente, por exemplo, de Elizabeth Ellsworth (COSTA; DE ANDRADE, 2016).

Ellsworth (2001) veio da área do Cinema e se interessou pela Educação ao pensar nas possíveis articulações que os dois campos poderiam ter. A autora entende que alguns dos conceitos que os estudiosos do Cinema usam sejam valiosos para também pensar a sala de aula, principalmente no que diz respeito às diferenças entre aquilo que o professor deseja alcançar e o que ele realmente alcança. A ideia principal seria a de que, assim como nos filmes, há sempre a intenção de atingir um determinado público de uma determinada forma, mas que isso nunca é totalmente possível, justamente por conta da variedade de vivências, personalidades e contextos que existem (ELLSWORTH, 2001).

Ellsworth (2005) também argumenta, assim como os outros autores já citados, que há vários espaços na sociedade que também são lugares de aprendizagem, não apenas a escola. Porém, afasta-se um pouco da ideia de currículo abordada anteriormente ao dizer que agentes como artistas, arquitetos e produtores de mídia têm intenção pedagógica ao pensar em suas obras (ELLSWORTH, 2005). Ao enfatizar 
que o carácter pedagógico é algo intencional, a autora, de certa forma, aproxima mais ainda essas instâncias midiáticas da sala de aula, por exemplo.

Entende-se aqui que o campo das Pedagogias Culturais é importantíssimo para pensarmos nas novas mídias também como pedagógicas, sendo elas instâncias culturais repletas de lutas de poderes e de significados. Esses autores mais clássicos do campo, citados ao longo desta seção, nos ajudam a compreender do que se trata essa relativamente nova área de conhecimento. No entanto, conforme apontam Andrade e Costa (2017), esse campo ainda está em construção e são necessárias pesquisas empíricas com essa articulação teórica para podermos discutir de forma mais concreta o que essas instâncias têm de pedagógicas e de que formas elas constroem significados na cultura.

Neste trabalho, optamos por fazer dialogar o campo da Pedagogia Cultural com a área da Sociologia da Infância, pois acreditamos que esta última possa nos ajudar a entender as culturas infantis de uma forma em que as crianças sejam protagonistas de suas histórias. Assim, discutiremos os conteúdos dos vídeos do YouTube entendendo-os como uma instância pedagógica e falaremos sobre as crianças e suas culturas a partir dos conceitos da Sociologia da Infância.

\section{3}

\section{Cultura Participativa}

Nesta seção do texto, nos dedicaremos a explicar como o YouTube pode ser visto como um espaço de cultura participativa, principalmente a partir dos trabalhos de Henry Jenkins (2015), Jean Burgess (2018), Joshua Green (2018) e Clement Chau (2010).

Antes de entrar especificamente na plataforma do YouTube, é necessário entendermos o panorama mais geral das mídias nos dias de hoje, para depois situar a plataforma nesse contexto. Henry Jenkins (2015) é um pesquisador norte americano que se dedica há mais de 30 anos a estudar as mídias, e, mais especificamente, suas mudanças ao longo do tempo. Em 2006, lançou a primeira edição do livro "Convergence Culture: Where Old and New Media Collide" (JENKINS, 2006), onde traz para público o conceito de cultura da convergência pela primeira vez. Em 2009, o livro foi traduzido e lançado no Brasil, sendo considerado uma obra 
essencial quando se fala de comunicação. Em sua edição mais atual, de 2015, o livro conta ainda com um capítulo dedicado a falar sobre a política na era do YouTube, mostrando a relevância social que a plataforma foi ganhando ao longo dos $\operatorname{anos}^{2}$.

Henry Jenkins (2015) define cultura da convergência como um momento em que "as velhas e as novas mídias colidem, onde a mídia corporativa e mídia alternativa se cruzam, onde o poder do produtor de mídia e o poder do consumidor interagem de maneiras imprevisíveis" (JENKINS, 2015, p. 29). O autor aponta três conceitos chave para entendermos esse momento.

O primeiro é o conceito de convergência, que abrange transformações de âmbitos tecnológicos, mercadológicos, culturais e sociais. É um momento em que é necessária uma presença ativa do consumidor, que se depara a todo momento com diferentes sistemas midiáticos oferecendo conteúdos e precisa criar conexões entre esses conteúdos dispersos. O segundo conceito é o de cultura participativa, visando romper com a ideia de que o consumidor é um receptor passivo e que se separa completamente do produtor de conteúdo - ele argumenta que é algo muito mais fluido e interativo. Por último, o autor aborda o conceito de inteligência coletiva de Pierre Lévy (1997 apud JENKINS, 2015) para dizer que essa convergência ocorre não por meio de aparelhos sofisticados, mas dentro de cada uma de nossas mentes, que, juntas, podem se configurar como uma fonte alternativa de poder midiático. Sobre isso, Jenkins explica que:

"Cada um de nós constrói a própria mitologia pessoal a partir de pedaços e fragmentos de informações extraídas do fluxo midiático e transformadas em recursos através dos quais compreendemos nossa vida cotidiana. Por haver mais informações sobre determinado assunto do que alguém possa guardar na cabeça, há incentivo extra para que conversemos entre nós sobre a mídia que consumimos. Essas conversas geram um burburinho cada vez mais valorizado pelo mercado das mídias. (JENKINS, 2015, p. 30)

Outro ponto que o autor levanta é o de que não concorda com esse argumento, muitas vezes visto no senso comum, de que as velhas mídias vão morrer e serão substituídas por novas. Ele explica que o que muda são as tecnologias de distribuição, como, por exemplo, as fitas cassete, ou os CDs, mas não os meios de

\footnotetext{
${ }^{2}$ O YouTube foi criado em 2005. As especificidades da plataforma serão abordadas mais à frente nesse capítulo e também no Capítulo 3.
} 
comunicação de fato. Nós não deixamos de usar o som gravado ou as palavras impressas desde que essas começaram a existir, assim como o cinema não eliminou o teatro - ou, para um exemplo mais atual, a Netflix não acabou com o cinema. O autor defende que esses meios de comunicação são sistemas culturais, que são sim transformados através do tempo, mas não são substituídos, eles convergem com as tecnologias atuais.

Esse argumento é semelhante ao que Buckingham (2019) apresenta em obra recente, apontando que, até nos dias de hoje, temos a tendência em separar totalmente as "mídias velhas" das "mídias novas", mas que isso não é válido, uma vez que elas, em diversos casos, se sobrepõem. O autor traz o exemplo de um serviço de streaming de vídeo como a Netflix, que é uma mídia nova, mas que está distribuindo filmes, que é uma mídia mais antiga, por exemplo. Na visão de Jenkins (2015) poderíamos dizer que o serviço de streaming seria a tecnologia de distribuição, que antes podia ser a televisão, mas que o meio de comunicação (filme) não deixa de existir.

Em termos conceituais, é importante ressaltar que Jenkins (2015) deixa claro em seu glossário que utiliza os termos "mídia" e "meio de comunicação" como sinônimos. Ele adota a definição de Lisa Gitelman, na qual os meios de comunicação seriam: "estruturas de comunicação realizadas socialmente, em que estruturas incluem tanto as formas tecnológicas quanto seus protocolos concomitantes, e em que a comunicação é uma prática cultural" (JENKINS, 2015, p. 383) . Neste trabalho, optamos também por utilizar ambos os termos com esse mesmo significado.

Outra definição importante de esclarecer é a de cultura participativa, um dos conceitos mais importantes para pensarmos o YouTube e que explica o contraste entre essa plataforma e as mídias tradicionais. Segundo Jenkins (2015), podemos defini-la como: "cultura em que fãs e outros consumidores são convidados a participar ativamente da criação e da circulação de novos conteúdos." (JENKINS, 2015, p. 378). Como já abordado anteriormente, a cultura participativa é uma das características da cultura da convergência, e, pensando especificamente sobre o YouTube, ela se torna a característica principal da plataforma (BURGESS; GREEN, 2018).

O livro "YouTube: Online Video and Participatory Culture" foi lançado em 2009 nos Estados Unidos, pela pesquisadora de estudos em mídia Jean Burgess e pelo jornalista Joshua Green. A obra foi traduzida para o português no mesmo ano 
com o título "YouTube e a Revolução Digital: como o maior fenômeno da cultura participativa transformou a mídia e a sociedade”. Em 2018, após 13 anos da criação do YouTube, os autores decidiram fazer uma nova edição do livro, atualizando e contextualizando o texto original e trazendo reflexões sobre as mudanças e o espaço da plataforma nos dias de hoje. Essa segunda edição ainda não foi traduzida para o português, por isso, li e usei como referência a versão de língua inglesa.

Uma das primeiras mudanças que os autores adotaram foi passar a chamar o YouTube de plataforma e não mais de site, uma vez que atualmente ele possibilita acesso através de aplicativo para celular e smart $T V$, por exemplo. Outro apontamento é que, antes, um dos capítulos do livro tinha como título "YouTube and the Mainstream Media" (traduzido como "O YouTube e a mídia de massa"); na edição de 2018, foi substituído por "Youtube and the Media", uma vez que não fazia mais sentido separar o YouTube dos outros meios de comunicação mais populares.

No próximo capítulo, explicaremos de forma mais aprofundada o funcionamento da plataforma do YouTube. Por ora, vamos apenas contextualizar o surgimento do YouTube e como ele se configura como espaço de cultura participativa, tendo como base a última edição do livro de Burgess e Green (2018) e alguns outros artigos que abordam tal temática.

O YouTube foi fundado em 2005 por três ex-funcionários da empresa PayPal, Chad Hurley, Steve Chen e Jawed Karim e tinha como objetivo quebrar as barreiras tecnológicas para que qualquer pessoa pudesse publicar seus próprios vídeos online. O site foi comprado um ano depois pelo Google, pela quantia de 1.65 bilhões de dólares. Burgess e Green (2018) apontam que a proposta inicial dos fundadores do YouTube se aproximava mais de criar uma rede social do que uma plataforma de mídia, e que desde o início não havia muita preocupação com o tipo de conteúdo que era publicado nem com quem o publicava, contanto que os números de usuários continuassem crescendo.

Sobre isso, Gillespe (2017) ressalta que todas essas plataformas, como o YouTube, o Facebook e o Twitter, têm como proposta hospedarem e organizarem conteúdos criados pelo público, sem produzirem seus próprios conteúdos. Entretanto, o autor salienta que, apesar de essa ser a proposta, precisamos ter em mente que essas plataformas escolhem o que vão distribuir ou não, de que forma esse conteúdo vai chegar para as pessoas e para quem ele vai ser entregue. Assim, é importante 
levantarmos o diálogo sobre o que é ou não da responsabilidade de tais plataformas na produção, distribuição e consumo dos conteúdos.

Esse é um ponto importante para prestarmos atenção. Atualmente, muito se discute na mídia sobre o posicionamento do YouTube (ou a falta dele) quando se trata dos conteúdos infantis, principalmente no que se refere às publicidades que são veiculadas. Discutiremos agora como funciona o básico do algoritmo do YouTube e quais são as medidas e políticas que a empresa tem adotado nos últimos anos em relação aos conteúdos infantis. 


\section{3}

\section{A plataforma do YouTube}

Desde 2008 o YouTube pode ser encontrado na maior parte das listas de sites mais visitados do mundo, aparecendo em segundo lugar em 2017, perdendo apenas para o próprio Google (BURGESS; GREEN, 2018). No Brasil, o YouTube chegou à marca dos 98 milhões de usuários no último levantamento realizado em 2017, tendo o adicional de 35 milhões desses usuários nos últimos 2 anos (PACETE, 2017). Por conta de todo esse impacto na vida dos usuários, é essencial entendermos qual é o lugar que o YouTube ocupa em nossa sociedade, principalmente como um espaço de cultura participativa.

Na plataforma do YouTube, o segredo do sucesso parece ser conseguir equilibrar autenticidade, intimidade e senso de comunidade, mesmo quando se está ganhando dinheiro por trás disso (BURGESS; GREEN, 2018). Burgess e Green (2018) apontam que essa é uma das principais características que afasta o YouTube das mídias tradicionais, assim como o fato de que são pessoas "normais" criando conteúdo, muitas vezes que começaram de forma amadora e sem pretensão de sucesso. Essa proposta inclusiva e aberta de que qualquer pessoa pode criar conteúdo na plataforma é justamente o valor central do YouTube - e é o que faz a cultura participativa ser sua característica mais marcante.

Os autores apontam que o YouTube pode ser considerado um grande sistema cultural, não apenas pelas funções que ele apresenta, mas principalmente pela forma com que ele foi apropriado pelos usuários, a partir dos conteúdos que são postados, do que é mais assistido e das interações que se estabelecem ali. Os youtubers aqueles que produzem os conteúdos - são de fato quem faz o trabalho criativo na plataforma, moldando, contestando e negociando a cultura que emerge do YouTube como um espaço de comunidade (BURGESS; GREEN, 2018). 
Clemente Chau (2010), assim como Burgess e Green (2018), argumenta que a plataforma do YouTube pode ser vista como um espaço de cultura participativa, onde é possível interagir com outras pessoas, se desenvolver e aprender através dos vídeos. O autor defende que o YouTube oferece para a juventude a possibilidade de serem criadores de mídias únicas e ao mesmo tempo interagirem com outros criadores e telespectadores. Chau (2010) ressalta que a cultura participativa é geralmente definida por 5 características, e demonstra como cada uma delas está presente na plataforma. As características apontadas por ele são:

1) Poucas barreiras para a expressão artística e participação;

2) Forte suporte para criar e compartilhar os projetos;

3) Mentoria informal;

4) Crença de que a contribuição importa;

5) A percepção de conexão social.

Esse capítulo do texto tem dois objetivos. O primeiro é tentar explicar, de maneira acessível, quais são as possibilidades de recursos e ações que a plataforma do YouTube oferece, mesmo pra quem não é usuário da mesma. Eu, como criadora de conteúdo na plataforma, consigo ver o que tem por trás das cortinas na hora de postar um vídeo ou de analisar seus resultados. Falaremos então da minha experiência como usuária, há mais de 5 anos, mas também traremos dados de pesquisas realizadas nos últimos tempos. Ilustraremos algumas das explicações com imagens, para que esse entendimento fique mais claro, principalmente para quem não tem contato frequente com o YouTube. O segundo objetivo dessa seção é abordar algumas das mudanças que o YouTube tem realizado ao longo dos anos que impactam diretamente na produção de conteúdo pelos youtubers e no consumo dos vídeos pelas crianças. Começaremos explicando um pouco do surgimento e funcionamento da plataforma.

Como já mencionado anteriormente, o YouTube foi lançado em 2005, visando quebrar barreiras técnicas e facilitar que qualquer pessoa pudesse compartilhar vídeos na internet, a partir de uma interface simples de uso (BURGESS et al., 2009). A plataforma conta com o slogan atual "Broadcast yourself', que, traduzindo para o português, seria algo como "transmita-se", passando uma ideia de exposição pessoal. 
Qualquer pessoa consegue acessar a plataforma de forma gratuita e assistir aos vídeos sem precisar de um cadastro na mesma. Porém, para conseguir interagir com os vídeos por meio de curtidas (os famosos likes) e para se inscrever em canais, desde que o YouTube foi adquirido pelo Google, é preciso ter uma conta gmail. Criar a conta é fácil e rápido, com uma única restrição - ter acima de 13 anos. Retomaremos a questão da idade mais à frente. Após a conta criada, todos os usuários têm a possiblidade, com poucos cliques, de abrir um canal na plataforma. Segundo o próprio YouTube, ter um canal significa sua presença pública na plataforma, sendo a única forma de você poder fazer comentários nos vídeos de outras pessoas, criar listas de vídeos favoritos (playlists) ou publicar seu próprio vídeo. Isso significa que, para você ter uma experiência completa na plataforma, você precisa criar um canal seu, mesmo que você não deseje produzir conteúdo.

Dessa forma, assim que um vídeo é carregado publicamente para o YouTube, outros usuários podem interagir através das curtidas e comentários. Além disso, é possível se inscrever no canal daquela pessoa, o que significa basicamente que você deseja continuar vendo os conteúdos que ela posta. Assim, os vídeos são sempre de um determinado canal, que conta com um número de inscritos, representando as pessoas que "seguem" aquele criador de conteúdo.

A navegação na plataforma pode ser considerada simples e intuitiva mesmo nos dias de hoje, seguindo a proposta inicial dos criadores do YouTube. Quando você entra na página inicial do YouTube, você se depara com uma série de vídeos recomendados. Se você entra nessa página inicial sem estar logado (cadastrado) em sua conta Google, o YouTube lhe recomenda vídeos que já estão em alta na plataforma, mas sem estarem ligados necessariamente a sua preferência, pois ele não tem seu histórico de navegação registrado para isso.

Se você estiver logado em sua conta, esses vídeos serão uma mistura de vídeos de canais em que você já é inscrito e outros vídeos aleatórios que o algoritmo entende que podem the agradar. Isso significa que é nessa tela, principalmente, que você descobre novos vídeos e canais para seguir. Estando na sua conta, é possível também acessar uma janela chamada "inscrições" onde estão apenas os vídeos dos canais em que você é inscrito - nessa janela, eles aparecem por ordem de postagem, estando os mais recentemente postados em cima.

Ao escolher um vídeo para assistir, você encontra todas as possibilidades de interação mostradas na Figura 1. As principais ações possíveis são: dar like (凸) ou 
dislike (『) no vídeo, compartilhá-lo em outras redes sociais, salvá-lo em uma playlist e denunciar o vídeo (opção que aparece quando você aperta nos “...” da direita). Você também pode se inscrever no canal apertando no botão vermelho "inscreverse" e, depois que aperta, pode ativar o sininho $(\Omega)$ de notificações, que faz com que você receba uma notificação toda vez que aquele canal postar um vídeo novo. Existe também o espaço de descrição do vídeo, onde o youtuber pode falar sobre o que é aquele conteúdo ou deixar links para você clicar.

Figura 1 - Possibilidades de interação com vídeo

\section{REAGINDO AOS TIK TOKS DA FAMÍLIA LOURES !!!}

128.035 visualizações $\cdot 25$ de mai. de 2020

$$
\text { If } 31 \mathrm{MIL} \text { I } 150 \rightarrow \text { COMPARTILHAR } \equiv+\text { SALVAR } \ldots
$$

LINK DO LIVRÃO CAMILA LOURES : https://www.camilaloureslivros.com.br...

MOSTRA ESSE CANAL PRA ALGUEM, UM DIA TEREMOS 50 MILHÕES DE INSCRITOS!! MOSTRAR MAIS

1.966 comentários $\equiv$ CLASSIFICAR POR

Adicionar um comentário público...

Fonte: Canal Camila Loures

Abaixo desse espaço, é o lugar dos comentários, onde é possível deixar uma mensagem pública para o youtuber e todos aqueles que assistem ao vídeo. Os comentários aparecem, por definição, por ordem de mais relevantes - geralmente aqueles com maior interação ou de contas grandes. Interação em um comentário é deixar likes ou dislikes ou responder ao comentário deixado. Segue exemplo de um comentário entendido como relevante para o YouTube, aparecendo como primeiro na lista de determinado vídeo:

Figura 2 - Comentário relevante

Duda Varela 51 minutos atrás

vídeos que precisam de outra parte:

1-salão da camis

2-oque tem na banheira

3-jogo de tabuleiro gigante

4-Polícia e ladrão na mansão loures

5-coisa,coisinha,coisão

6-pique esconde na mansão loures

7-quem faz a melhor foto na mansão loures

Mostrar menos

I 420 RESPONDER

- Ver 20 respostas

Fonte: Canal Camila Loures 
É importante também sabermos o que acontece ao entrarmos em algum canal do YouTube. A Figura 3 ilustra um exemplo. Todos os canais contam como um banner, que seria a capa do canal. Em cima desse banner geralmente existem links para outras redes socais do youtuber. Logo abaixo do banner, podemos ver a foto de perfil e o número de inscritos com um sinal de "verificado". Esse sinal é conseguido por canais com mais de 100 mil inscritos e que seguem as condições descritas na Figura 4, retirada do próprio YouTube.

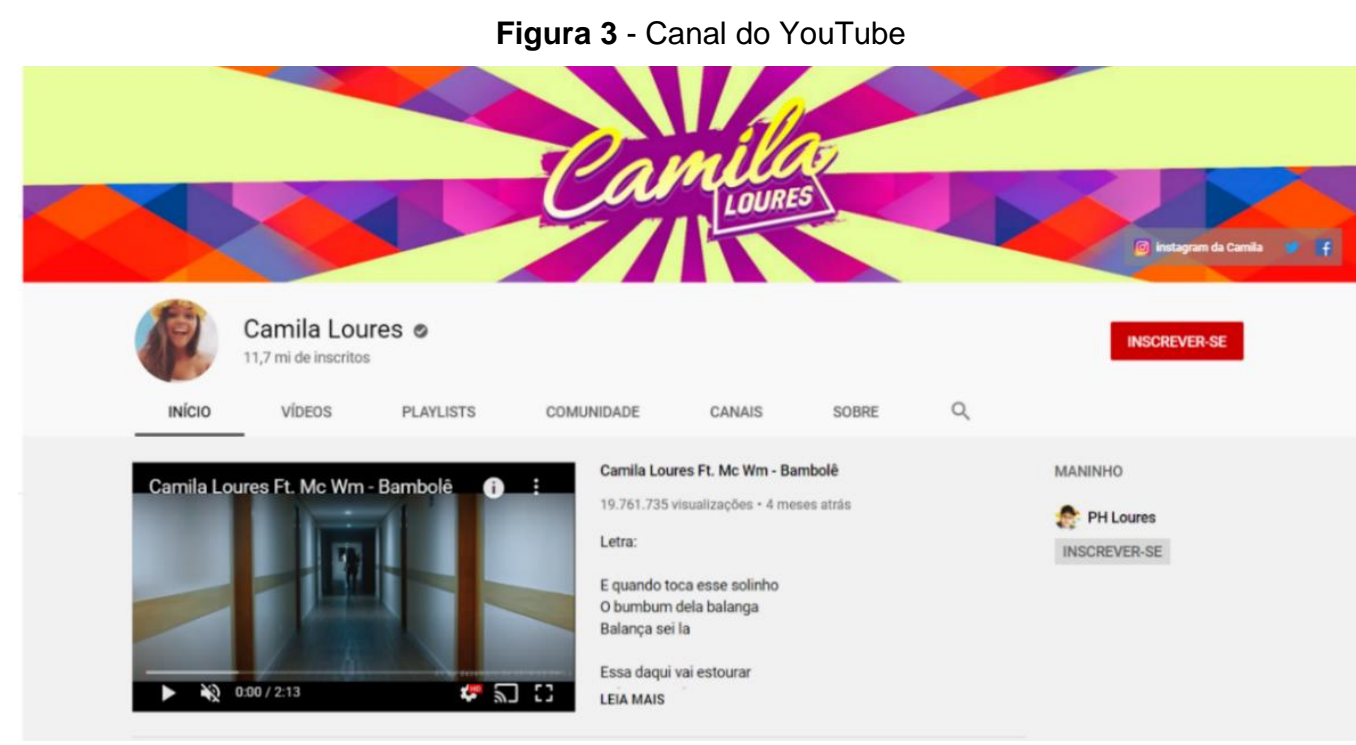

Fonte: Canal Camila Loures

Figura 4 - Qualificação para verificação de canal

\section{Qualificação para verificação de canal}

Você precisa ter 100 mil inscritos para solicitar a verificação.

Depois disso, analisaremos seu canal. Para ser verificado, o canal precisa ter as seguintes características:

- Ser autêntico: representar o verdadeiro criador de conteúdo, marca ou entidade que afirma ser. Vários fatores diferentes serão analisados para confirmar a identidade, como a idade do canal. Também poderemos solicitar mais informações ou documentos.

- Ser completo: ele precisa ser público e ativo no YouTube, além de ter descrição, banner, ícone e conteúdo.

Em alguns casos, o YouTube também verificará de maneira proativa os canais com menos de 100 mil inscritos que sejam conhecidos fora da plataforma.

Fonte: YouTube

A primeira aba (Figura 3), "início", mostra um vídeo em destaque que foi escolhido pelo youtuber - geralmente um clipe de uma música feita por ele ou algum vídeo de apresentação, algumas vezes chamado de trailer do canal. Ao lado, é possível ver também canais que o youtuber elegeu para ficar em destaque - no caso da figura, o canal do irmão dela. É comum deixarem nesse espaço outros canais do 
mesmo dono, por exemplo um canal de $v \log ^{3}$ e outro de jogos, ou um canal pessoal e outro só de maquiagem. Embaixo dessa primeira parte, é possível escolher se você deseja mostrar suas playlists de vídeos ou simplesmente os envios mais recentes, algo que fica a critério de cada criador de conteúdo.

$\mathrm{Na}$ aba "vídeos" você consegue ver todos os vídeos daquele canal, por ordem de postagem, estando os mais recentes no início da lista. A parte de "playlist" é onde os vídeos estão geralmente agrupados por categorias, como por exemplo vídeos de slime $^{4}$, vídeos de desafios etc. A aba "comunidade" é mais recente no YouTube, foi lançada em 2016 e possibilita que os youtubers interajam ainda mais com os inscritos, deixando recados e postando fotos para toda a comunidade de seguidores. Na aba "canais" é possível ver novamente o canal em destaque e em "sobre" você consegue ver a descrição daquele canal, o número total de visualizações e desde quando o canal existe.

Essas são as principais formas de interação que um usuário pode ter com a plataforma e com o youtuber. Talvez não esteja tão clara qual a importância de entenderem esses detalhes "técnicos", mas consideramos que conhecer a plataforma a fundo seja imprescindível para debatermos os usos que as crianças fazem da mesma, assim como as possibilidades que um youtuber tem na hora de postar um conteúdo. Entenderemos agora um pouco mais o processo de postagem de vídeo no YouTube.

Com um canal criado, qualquer pessoa tem a possibilidade de postar um vídeo: basta ir ao ícone de filmadora que fica no canto superior direito da tela, conforme mostrado na Figura 5.

Figura 5 - Ícone de filmadora

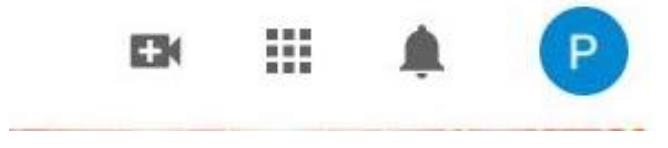

Fonte: YouTube

\footnotetext{
${ }^{3}$ A categoria vlog será mais explorada nos próximos capítulos, mas basicamente consiste em vídeos em que o youtuber mostra seu dia a dia, sua rotina, viagens etc, conversando com os espectadores de forma mais descontraída.

${ }^{4}$ Slime é uma massinha gelatinosa e colorida que virou febre entre as crianças, sendo bastante parecida com as antigas "gelecas" ou "amoebas", o diferencial do slime é a possibilidade de fazer o seu em casa, usando diversos tipos de ingredientes.
} 
Você então escolhe o arquivo desejado em seu computador (ou celular) e, enquanto espera carregar (fazer upload), você precisa preencher algumas informações sobre aquele conteúdo. Além do básico (Figura 6), que é o título, descrição e miniatura (capa do vídeo), uma importante atualização do YouTube em 2019 foi incluir a seguinte pergunta: Este vídeo é para crianças? Essa pergunta é obrigatória de ser respondida sempre que alguém posta um vídeo. Se a pessoa seleciona a opção "Sim, é conteúdo para criança", você se depara com a mensagem da Figura 7. Além dessa pergunta, também tem a opção de restringir o seu vídeo a espectadores maiores de 18 anos (Figura 8), proibindo que aqueles com idade entre 13 e 18 anos assistam ao vídeo.

Figura 6 - Upload de vídeo

Salvando rascunho... $\times$
A Detalhes
Elementos do vídeo
Visibilidade

\section{Detalhes}

Título (obrigatório)

Adicione um título que descreva seu vídeo

Descrição (?)

Fale sobre seu vídeo para os espectadores

Fale so
$0 / 100$

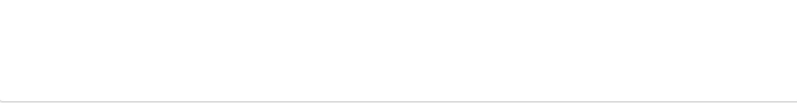

Miniatura

Selecione ou faça upload de uma imagem que mostre o que há no seu vídeo. Uma boa

miniatura se destaca e chama a atenção dos espectadores. Saiba mais

+ ค

Fonte: YouTube 
Figura 7 - Vídeo para crianças

\section{Público}

Este vídeo é para crianças? (Obrigatório)

Não importa sua localização, é obrigatório obedecer à Lei de Proteção da Privacidade Online das Crianças (COPPA, na sigla em inglês) e/ou a outras leis. É obrigatório informar se o conteúdo é para crianças. 0 que é conteúdo para crianças?

Sim, é conteúdo para crianças

Recursos como anúncios personalizados e notificações não estarão mais

disponiveis em vídeos de conteúdo para crianças. É mais provável que vídeos

(i) com essa configuração sejam recomendados em conjunto com outros vídeos de conteúdo para crianças. Saiba mais

Não, não é conteúdo para crianças

Fonte: YouTube

Figura 8 - Restrição de idade

^ Restrição de idade (avançado)

Quer restringir seu vídeo apenas para o público adulto?

Esse tipo de conteúdo é ocultado em determinadas seções do YouTube. Por padrão, vídeos com restrição de idade não exibem anúncios e não geram receita. Saiba mais

Sim, restringir meu vídeo a espectadores maiores de 18 anos

Não restringir meu vídeo a maiores de 18 anos

\section{MAIS OPÇÕES}

Promoção paga, tags, legendas e mais

Fonte: YouTube

Se a pessoa clica na opção "O que é conteúdo para criança?” (Figura 7) é possível ver quais critérios o YouTube indica para ajudar o criador de conteúdo a decidir se seus vídeos são ou não para essa faixa etária. Esta é uma ação que pode ser feita no canal como um todo ou em vídeos específicos. Abaixo podemos ver os principais pontos a serem observados nessa decisão, que estão elencados de forma mais completa nas orientações da plataforma:

É preciso considerar vários fatores ao decidir se o seu canal ou vídeo tem conteúdo para crianças, incluindo: 
- o tema do vídeo (por exemplo: conteúdo educativo para crianças em idade préescolar);

- $\quad$ se as crianças são apenas o público-alvo ou os espectadores reais do seu vídeo;

- $\quad$ se o vídeo apresenta atores ou modelos infantis;

- $\quad$ se o vídeo mostra personagens, celebridades ou brinquedos infantis, incluindo aqueles que aparecem em filmes e desenhos animados;

- $\quad$ se a linguagem do vídeo é adequada para crianças;

- se o vídeo mostra atividades que são do interesse de crianças, como teatrinhos, músicas ou jogos de fácil assimilação ou relacionados à educação infantil;

- $\quad$ se o vídeo contém músicas, histórias ou poemas para crianças;

- outras informações que possam ajudar a determinar o público do seu vídeo, como evidências empíricas de quem são os espectadores do conteúdo;

- $\quad$ se a promoção dos vídeos é feita para atrair crianças.

O fato do seu vídeo se encaixar em alguns desses fatores não faz com que ele seja conteúdo para crianças. É preciso pensar com cuidado em qual público você está tentando alcançar com os vídeos quando for analisar seu conteúdo e os fatores acima. (YOUTUBE, 2020a)

Antes de falarmos sobre as mudanças que ocorrem em canais com conteúdo para criança, precisamos entender a questão da idade dos usuários na plataforma. Como já explicamos, a restrição de idade para se criar uma conta do Google, e, consequentemente do YouTube, é que se tenha 13 anos. Então, as crianças que ainda não têm essa idade teriam três opções: 1) assistir aos vídeos sem uma conta e não conseguir interagir com os conteúdos; 2) usar contas de seus familiares, ou 3) colocar uma idade falsa - acima de 13 anos - na hora de criar a conta. Por causa dessa regra, não há dados disponíveis que apontem quantas crianças menores de 13 anos estão assistindo ao YouTube.

O YouTube criou em 2015 (OFFICIAL YOUTUBE BLOG, 2015) um aplicativo dedicado ao uso das crianças, chamado YouTube Kids, visando protegê-las de conteúdos inapropriados e garantindo mais possibilidades de supervisão por parte da família. Sabemos, entretanto, tanto pelos dados encontrados nessa pesquisa quanto pela observação no dia a dia, que muitas crianças não acessam o YouTube Kids, mas sim a plataforma regular. Por isso o foco desse trabalho será o YouTube, não descartando a necessidade e importância de o YouTube Kids também ser fonte de pesquisas acadêmicas.

O próprio YouTube demonstra em suas ações saber que as crianças menores de 13 anos estão acessando a plataforma regular, e não apenas o YouTube Kids. Isso fica claro justamente quando se aplica uma política de indicação classificativa dos vídeos mesmo havendo a restrição de se obter uma conta somente a partir dos 13 anos. Levando em consideração esse cenário, vamos falar um pouco sobre o 
motivo dessa indicação de faixa etária dos vídeos e das consequências que isso tem para um canal.

A opção de classificar um vídeo ou canal como "para crianças" começou a ser implementada no final de 2019, a partir de um contrato que o YouTube assinou com a Comissão Federal do Comércio dos Estados Unidos (FTC), responsável por verificar o cumprimento da Lei de Proteção da Privacidade On-line nas Crianças (COPPA). A COPPA basicamente visa proteger as informações pessoais das crianças que são coletadas online, dando aos pais ferramentas para controlar quais informações serão, ou não, coletadas. A partir do dia 6 de janeiro de 2020, algumas mudanças começaram a ser realizadas nos canais ou vídeos sinalizados como "para crianças", visando cumprir com a lei de privacidade online.

O vídeo Features impacted by COPPA: Made for Kids content (2020) aponta os recursos que são ou podem ser desativados dos vídeos sinalizados como "para crianças", justamente por necessitarem de coletas de dados pessoais: anúncios personalizados, recursos específicos de monetização, comentários, bate papo ao vivo, sino de notificação, playlists e miniplayer. Se você classificar o seu canal inteiro como dedicado para crianças, ainda serão desativados os recursos de criar stories e a aba de comunidade.

Nesse primeiro momento, o YouTube está confiando que os produtores de conteúdos são aqueles que melhor podem avaliar e informar se fazem ou não conteúdos para crianças, podendo penalizar aqueles que classificarem seus vídeos de forma errada (Figura 9).

Figura 9 - Penalização de criadores de conteúdos

Observação: como criador de conteúdo, ninguém conhece seus vídeos e seu público tão bem quanto você. Por isso, é sua responsabilidade legal garantir a conformidade do seu canal com a COPPA e/ou outras leis aplicáveis, além de classificar seu conteúdo corretamente. Se você não categorizar seu conteúdo corretamente, poderemos aplicar penalidades à sua conta do YouTube. Além disso, poderá haver consequências legais de acordo com a Lei de Proteção da Privacidade On-line das Crianças (COPPA) $\square$ ou outras legislações locais aplicáveis.

Fonte: YouTube

Essas mudanças não foram recebidas bem por parte da comunidade de youtubers, alguns até estão migrando de plataforma (GOMES, 2020), principalmente 
por afetar a monetização dos vídeos - algo que, para muitos, é a única fonte de renda ${ }^{5}$.

O acesso à plataforma no Brasil teve um grande crescimento nos últimos 2 anos, chegando à marca de 98 milhões de usuários mensais (PACETE, 2017). Por conta da restrição de idade e das formas de burlar isso, é difícil chegarmos a dados exatos e relatórios sobre o uso da plataforma pelas crianças menores de 13 anos. Talvez futuramente tenhamos dados a partir dos vídeos que estão sendo classificados como "para crianças", mas, como isso é algo muito recente e atualmente fica sob responsabilidade do youtuber, ainda não é possível utilizar esse critério. Assim, resta-nos entender quais canais as crianças estão assistindo a partir do tipo de conteúdo que é produzido, da forma como os vídeos são apresentados e dos tipos de comentários que são deixados. Na última sessão do capítulo seguinte traremos alguns estudos realizados sobre o uso da plataforma pelas crianças, tanto como produtoras quanto como consumidoras dos vídeos.

${ }^{5}$ A monetização do YouTube é um assunto complexo, que precisaria de páginas para ser explicada. Mas, resumidamente, um youtuber ganha dinheiro a partir das visualizações e cliques em propagandas que são exibidas antes, durante e depois de seus vídeos, além dos banners que ficam abaixo e ao lado do player. O conteúdo dessas propagandas não pode ser escolhido pelo youtuber, mas, em geral, se relaciona com o tema do vídeo e com os dados coletados do usuário. Uma das limitações dos vídeos destinados às crianças é justamente não permitir mais essas propagandas personalizadas a partir de seus dados, o que pode significar que menos anunciantes vão querer estar presente naquele vídeo, afetando, assim, a monetização do canal. 


\section{4}

\section{Revisão Empírica}

Esta seção está dividida em três partes. Na primeira, recorremos aos estudos sobre a recepção dos conteúdos televisivos pelas crianças. Como os estudos sobre o YouTube ainda são muito recentes e há pouca produção acadêmica, decidimos revisitar estudos sobre a relação das crianças com a televisão, até mesmo para pensarmos nas possíveis diferenças e semelhanças que essas mídias apresentam. A segunda parte é dedicada a falar dos estudos que estão sendo realizados sobre as crianças e os conteúdos a que elas têm acesso na internet, discutindo o que a literatura aponta como fatores de risco e o que define como conteúdos positivos. Por fim, na terceira parte, iremos apresentar e articular os trabalhos empíricos que existem sobre a temática do YouTube, seu lugar na infância contemporânea e os conteúdos que as crianças produzem e assistem na plataforma.

\section{1}

\section{Os estudos sobre as crianças e a televisão}

Nos anos 60 e 70, estudos estavam sendo feitos, principalmente nos Estados Unidos, alertando sobre o perigo da violência transmitida pela televisão, vista como sendo uma das maiores influências para atos e comportamentos violentos de crianças e adolescentes (WARTELLA; OLIVAREZ; JENNINGS, 1999). Vindo de uma tradição behaviorista, os estudos iniciais de Bandura (1978) buscavam entender essa influência da TV nos comportamentos das crianças. $\mathrm{O}$ autor desenvolveu a partir de seus experimentos a chamada Teoria da Aprendizagem Social, que tem como pressuposto que nós podemos aprender não somente vivenciando diretamente uma experiência, mas também observando aquilo que o outro faz, o que se configura em uma aprendizagem observacional. Seus primeiros estudos com crianças e televisão mostraram que através dos processos de atenção, representação, 
reprodução e simbolização, ocorreria essa aprendizagem pela observação. Os estudos que Bandura realizou foram de grande impacto para a argumentação de que conteúdos televisivos violentos possuiriam influência nos comportamentos agressivos das crianças (RANGEL, 2004), mesmo que o autor ao longo dos anos tenha ressaltado cada vez mais a importância de se considerarem outros fatores externos e internos nessa influência.

Apesar de Bandura ter sido um autor que apontou a agência dos sujeitos, o foco dos estudos sobre televisão continuou durante muitos anos sendo em identificar quais influências essa mídia tinha sobre as crianças, muitas vezes com um viés reducionista e bastante crítico. Gunter e McAleer (1997) apontam que houve uma tendência em focarem apenas no lado negativo dos efeitos da televisão, pois isso renderia notícias muito mais impactantes do que falar sobre as boas influências que essa mídia poderia ter. Os autores ressaltam que é muito comum que façam a televisão de "bode expiatório", atribuindo a ela várias causas para os problemas que a sociedade enfrenta, sem adotar um olhar mais amplo para o cenário. Falar de influência é algo bastante delicado e com muitas variáveis, então há de se ter um cuidado muito grande ao fazer afirmações generalistas e alarmistas, ainda mais quando os estudos empíricos, apesar de numerosos, são questionáveis quanto a sua robustez e confiabilidade nos achados (GUNTER; MCALEER, 1997).

Esses autores ingleses, Berrie Gunter e Jill McAleer, lançaram em 1990 a primeira edição do livro Children and Television: The One-Eyed Monster? O objetivo da obra era responder a perguntas frequentemente realizadas sobre a relação das crianças com a televisão, a partir de resultados empíricos de pesquisas acadêmicas. Cada capítulo do livro corresponde a uma dessas perguntas, como por exemplo: o porquê de as crianças assistirem à televisão, o quanto elas conseguem entender do que estão assistindo, se a televisão ensina sobre papeis sociais, se influencia em comportamentos agressivos, se encoraja um bom comportamento ou até mesmo se afeta o desempenho na escola. O livro teve sua segunda edição em 1997 (edição aqui usada) e terceira em 2020, na qual os autores deixam claro no prefácio que poucas mudanças ocorreram nas respostas a tais perguntas, apesar de o cenário midiático estar completamente transformado.

O livro (GUNTER; MCALEER, 1997) é bastante cuidadoso ao apontar algumas lacunas das pesquisas acadêmicas, principalmente no que diz respeito aos métodos utilizados e à não compreensão de uma criança como ativa em seu processo 
de recepção televisiva. Os autores ressaltam que, após a revisão bibliográfica que foi realizada, é possível afirmar que as crianças não sentam passivamente frente às telas e simplesmente absorvam aquele conteúdo, mas que são ativas ao selecionar aquilo que desejam assistir de acordo com seus desejos e necessidades e ao dar seus próprios significados para aqueles conteúdos, a partir de suas personalidades e vivências (GUNTER; MCALEER, 1997). Além disso, Gunter e McAleer (1997), ao longo do livro, trazem diversas pesquisas que abordam os possíveis efeitos positivos que a televisão pode ter, como, por exemplo, ajudar a desenvolver habilidades intelectuais e influenciar positivamente no comportamento. Os autores deixam claro, entretanto, que isso não significa abrir mão do cuidado que devemos ter com os conteúdos a que as crianças assistem, principalmente no que se refere aos conteúdos considerados impróprios para a idade. A conclusão de Gunter e McAleer (1997) é de que tudo depende de como a televisão é utilizada, da mediação que é feita e de como esses conteúdos se relacionam com os outros aspectos da vida das crianças, influenciando, assim, a forma com que elas entendem e interpretam os mesmos.

Na América Latina, têm-se produzido muitas pesquisas nas últimas décadas que também levam em consideração uma criança que é agente de sua própria história, se aproximando mais da concepção que escolhi trabalhar nessa pesquisa. Dessa forma, priorizarei para essa revisão artigos Latino-Americanos que entendam que a criança é ativa em seu processo de recepção televisiva. A maior parte desses artigos se aproxima mais do campo dos Estudos Culturais e da Teoria da Recepção, utilizando como metodologia a análise dos conteúdos de programas televisivos e/ou entrevistas com as próprias crianças.

Valerio Fuenzalida $(1987,1995,1996,2008,2011)$ é um autor chileno que se dedicou a estudar a relação das crianças com a televisão, tendo como foco as motivações que as mesmas têm para assistir aos conteúdos. Fuenzalida (1987, 1996), assim como Gunter e McAleer (1997), ressalta o reducionismo que muitas pesquisas cometem ao apontar a televisão como grande vilã da violência nas últimas décadas, ainda mais quando pensamos na América Latina. $\mathrm{O}$ autor diz que é comum quererem transpor essas preocupações que surgiram nos Estados Unidos e na União Europeia para a América Latina, mas que não se pode fazer isso de maneira ingênua, sem deixar de considerar os reais problemas de cada cultura. Fuenzalida (1996) enfatiza que os países da América Latina sofrem com uma forte violência sócio- 
política, que as crianças crescem inseridas em uma cultura violenta dentro de suas casas e que a violência contra mulher tem números alarmantes.

Os dados de pesquisas realizadas no Chile na década de 90, mostraram também que a televisão não estava tão saturada assim de programas e cenas violentas como se argumentava, com um índice de 5,17\% de cenas com elementos conflitivos em programas adultos e apenas 3,57\% na programação infantil (FUENZALIDA, 1996). Fuenzalida (1996) aponta que a ideia de uma televisão boa para crianças ser simplesmente uma televisão sem violência, faz com que a discussão se empobreça, ao invés de avançar para propostas e orientações práticas para os produtores de televisão, sobre como criar programas que estimulem a criatividade, que sejam atrativos e interessantes para as crianças.

Pode parecer ultrapassado olharmos dados e pesquisas da década de 90 que falem sobre televisão, mas iremos argumentar aqui que os apontamentos e as preocupações que foram levantadas nessa época são bastante parecidos com as das discussões que vemos hoje em dia sobre a Internet e o YouTube. O foco do discurso do senso comum é do medo dos conteúdos a que as crianças estão tendo acesso e da possível influência que esses conteúdos podem ter nos valores, hábitos e atitudes das crianças, muitas vezes em tons alarmistas. Essa tendência de ir para uma visão ou bastante pessimista ou totalmente positiva é comum sempre que uma nova mídia surge, como já apontado pelo famoso livro "Apocalípticos e Integrados" de Umberto Eco (1984). O interesse em trabalhar com esses estudos que vêm sendo realizados na América Latina sobre o tema é justamente pela opção dos autores de adotar uma visão menos dualista e mais consciente do universo infantil.

Fuenzalida (1996), nesse sentido, ressalta a importância de se conhecer e respeitar as motivações que as crianças têm para assistir televisão, ao invés de pensar apenas em objetivos didáticos e escolares a partir de uma visão adulta. Em geral, as pesquisas apontam que as crianças gostam mais de programas com conteúdos lúdicos, subversivos, com humor ou personagens fortes que enfrentam os problemas cotidianos, algo que vai muito mais para o lado do afeto, se afastando da escola e de conteúdos escolares (FUENZALIDA, 1996). Foram encontradas nas pesquisas, resumidamente, as seguintes motivações que as crianças têm para assistir televisão:

a) A necessidade de compartilhar em família os programas televisivos, tanto para distração pelo humor quanto para reconhecer o entorno social e ecológico com os problemas que afetam a vida cotidiana; 
b) Ao espreitar sobre os conflitos afetivos (vedados e ocultos) dos adultos através da ficção de novelas;

c) Necessidade de confirmar a autoestima e a capacidade de realização, o fortalecimento para superar fraquezas, cansaço, temores, fracassos; frequentemente tal confirmação é fruto do humor que desdramatiza as situações estressantes;

d) Vivências simbólicas-lúdicas de "maldades e loucuras";

e) Motivações à ação épica e ao protagonismo; curiosidade e motivação ao descobrimento, à aventura, ao mistério; frequentemente tal ação é mais motivante "em equipe" ou "em gangue";

f) Motivações de manipulação lúdica de objetos e brinquedos;

g) Interesse pelo futuro, simbolizado em relatos espaciais.

(FUENZALIDA, 1997, p. 251)

Fuenzalida (1997) aponta que é preciso levar tais motivações em consideração quando se pensa em criar conteúdos infantis televisivos. Acrescenta ainda que é preciso não infantilizar as crianças de modo pejorativo, mas sim tratá-las como sujeitos criativos, ativos e capazes de entender o mundo. Outro aspecto importante mencionado pelo autor é a incorporação de novas tecnologias da época como vídeo games e vídeos nos programas infantis, assim como avançar na criação de conteúdos interativos e trabalhar com múltiplas mídias e plataformas. Essas constatações realizadas no final da década de 90 já ajudam a explicar o porquê de as crianças passarem horas de seus dias entretidas assistindo vídeos no YouTube - discutiremos isso nos próximos capítulos.

Ao longo das pesquisas etnográficas sobre a recepção dos conteúdos pelas crianças também foi possível perceber que muitas vezes elas voltam de longas horas na escola cansadas, sentindo-se tristes com seu rendimento ou fracasso escolar e encontram nos programas televisivos uma oportunidade para descasarem, rirem e se divertirem (FUENZALIDA, 2008). Fuenzalida (2008) ressalta que esse é um possível motivo para as crianças terem preferência pelos desenhos de humor e comédia, pois esses desenhos ajudam-nas, por meio da risada, a relaxar e enfrentar os desafios do cotidiano.

O autor aponta que muitos dos desenhos de sucesso são os que apresentam: personagens infantis fortes e criativos, como "Bob, o construtor" e "Dora a aventureira", personagens adultos bobos e engraçados, como "Pato Donald" e em "Os Simpsons" e personagens medrosos que enfrentam os temores infantis, como em "Scooby Doo" e "Coragem, o cão covarde". Essas preferências ilustram justamente como esses esquemas lúdicos e dramáticos dos desenhos animados não são simplesmente uma distração fútil para a criança como muitos podem pensar, mas sim 
uma oportunidade para elas entenderem o mundo e poderem lidar com seus desejos e frustações (FUENZALIDA, 2008).

Orozco-Gómez (1991), outro importante pesquisador latino-americano, explora a fundo a questão da recepção dos conteúdos televisivos pelas crianças, tendo como foco principal as mediações que são feitas durante esse processo. Um dos pressupostos do autor é de que o telespectador não é um receptor passivo nesse processo de recepção televisiva. Não entende que quem está diante da tela simplesmente internaliza e reproduz tudo aquilo que está vendo. Ao contrário, existe uma série de diferentes envolvimentos e processamentos possíveis daquele conteúdo que está sendo consumido. É um processo que ele diz ser essencialmente sociocultural. A pessoa que está ali tem emoções, histórias sobre aquilo que já viveu e expectativas sobre aquilo a que está assistindo. Tudo isso influencia em como esse processo de recepção vai ocorrer para cada um. Para explicar melhor como isso ocorre e o que pode influenciar o processo, o autor apresenta os conceitos de mediação situacional, institucional e de referência.

A mediação situacional diz respeito à situação em que a pessoa está enquanto assiste ao programa - ou seja, se está sozinha naquele momento ou tendo a opinião de um outro sobre aquilo a que está assistindo, se está prestando atenção somente à televisão ou brincando, comendo, falando ao mesmo tempo, se a televisão fica em um cômodo central da casa e está sempre ligada etc. Já a mediação institucional se refere à ideia de que aquela pessoa que está assistindo à televisão não é apenas um telespectador, mas também é filho, aluno, vizinho ou amigo de pessoas de uma determinada cultura, por exemplo. Dessa forma, pertence também a todas essas outras instituições e é influenciada também por elas. Por fim, vários referentes culturais daquele telespectador também agem como mediadores no processo de recepção. As pesquisas apontam (OROZCO-GÓMEZ, 1991) que o gênero é um fator de importância para a determinação dos gostos de cada pessoa, os horários em que ela assiste à televisão e a forma de se apropriar do que está assistindo. A etnia e a origem social e geográfica também são referentes apontados como importantes, assim como a idade do telespectador - este último principalmente quando estamos falando de crianças e adolescentes.

Em estudo realizado por Duarte, Leite e Migliora (2007) as autoras trazem apontamentos interessantes sobre a relação das crianças com a televisão. O estudo tinha como objetivo descrever e compreender essa relação, a partir do ponto de vista 
das próprias crianças. A metodologia utilizada foi a análise de mais de quatrocentos textos e desenhos de crianças da região sudeste do Brasil, com idades entre 8 e 12 anos. Nesses textos e desenhos, as crianças expressavam o que pensavam sobre aquilo a que assistiam na televisão.

Alguns achados interessantes caminham na linha de que as próprias crianças apontam a educação como uma das principais atribuições da televisão, dizendo que em todos os canais é possível aprender um pouco. Por outro lado, elas diziam que essa função de educação não vinha sendo tão bem cumprida, já que muitas vezes a televisão mostra conteúdos que elas não consideram adequados. Ou seja, as crianças reconhecem que sim, a televisão ensina, mas não necessariamente coisas boas, pois há vários programas com “coisas que não prestam” ou que "prejudicam as crianças" (DUARTE; LEITE; MIGLIORA, 2007, p. 502).

Com a análise dos textos e desenhos, as autoras também perceberam que as crianças consideram que a televisão ensina mostrando, com uma associação bem forte entre mostrar e ensinar. Apesar disso, elas relataram que nem todo mundo se deixa influenciar por aquilo a que está assistindo, pois é possível identificar o que é ruim e "faz mal" e separar daquilo que é bom. Para as crianças participantes da pesquisa, são as crianças bem pequenas e os adolescentes que teriam maior dificuldade em conseguir não se deixar ser influenciado por aquilo que está sendo mostrado, diferentemente deles mesmos, que dizem saber escolher o melhor caminho para seguir.

As principais conclusões do estudo são de que as crianças analisam a televisão com bastante competência, pois esse é um tema que é familiar e interessante para elas, construindo opiniões sofisticadas, críticas pertinentes e bem elaboradas. Justamente por assistirem muita televisão, as crianças mostram conhecê-la também pelo lado de dentro, relatando sua lógica interna, sua estrutura de produção e linguagem específica. Tudo isso sugere que as crianças não são espectadoras idiotizadas, com percepções ingênuas sobre o que assistem, mas sim verdadeiras especialistas sobre o tema e que acreditam no papel social de educação que a televisão desempenha (DUARTE; LEITE; MIGLIORA, 2007).

Por mais que esses estudos que usam a teoria da recepção tenham como foco a televisão, seus conceitos e ideias também podem se estender para outras tecnologias da comunicação (TEODORO DA SILVA; CARDOSO, 2016). Pensando especificamente no YouTube, esse processo conta ainda com vários fatores 
diferenciados e atraentes, como a maior identificação com a pessoa por trás da tela e a facilidade de interação com o telespectador. Nesse sentido, foi importante realizar uma revisão empírica tanto dos estudos focados em televisão - que são inúmeros - quanto dos mais atuais, que têm como foco a internet e, mais especificamente, o YouTube.

\section{2}

\section{Os estudos sobre as crianças e os conteúdos online}

Antes de falarmos especificamente sobre o YouTube, é importante conhecermos o cenário mais amplo em relação ao acesso à internet no Brasil e aos estudos que vêm sendo realizados sobre a relação das crianças com os conteúdos online.

O Centro Regional de Estudos para o Desenvolvimento da Sociedade da Informação (CETIC.br) tem o objetivo de monitorar, desde 2005, a adoção das tecnologias de informação e comunicação (TIC) no Brasil. O CETIC.br realiza desde 2012 a pesquisa TIC Kids Online Brasil, que visa gerar dados acerca das oportunidades e riscos que crianças e adolescentes de 9 a 17 anos podem ter relacionados à navegação online. A pesquisa é feita anualmente de forma amostral, a partir de entrevistas presenciais em domicílios de áreas urbanas e rurais do Brasil. Utilizaremos aqui os dados mais recentes da pesquisa, coletados entre outubro de 2019 e março de 2020 e apresentados para a imprensa em junho de 2020.

Os resultados da pesquisa apontam que 3 milhões de crianças e adolescentes não são usuárias de internet no Brasil, o que representa aproximadamente $11 \%$ da população nessa faixa etária. Dessas, 1.4 milhões nunca acessaram a internet. Os números de não-usuárias aumentam quando olhamos para a zona rural, para as crianças mais novas e para as classes sociais mais baixas. Nas classes AB, 100\% das crianças e adolescentes usaram a internet nos 3 meses anteriores à coleta de dados, enquanto na classe DE apenas $80 \%$ relatam ter usado. Alguns dos principais motivos relatados para não usarem a internet são: não terem internet em casa (6\%), a internet não ser para pessoas da sua idade (5\%), não saberem usar a internet (4\%), não terem vontade de usar (4\%), seus responsáveis não deixarem (4\%) e não poderem usar internet nas escolas (4\%). 
É essencial considerarmos que o acesso à internet não está democratizado como se pode pensar no senso comum. No Brasil, 4,8 milhões de crianças e adolescentes vivem em casas sem acesso à internet, o que representa $18 \%$ dessa população. Na região sudeste, onde foi realizada a pesquisa apresentada nesta dissertação, esse número cai para $4 \%$. No entanto, é importante considerar que ter acesso à internet não significa ter uma qualidade de conexão constante e estável, como ficou claro no período de COVID-19 em que várias pessoas precisavam usar a internet ao mesmo tempo e muitas vezes até no mesmo dispositivo.

Focaremos agora nas oportunidades e práticas que as crianças de 9 e 10 anos têm na internet, uma vez que essa é aproximadamente a mesma faixa etária dos participantes da pesquisa desta dissertação. Em relação às atividades de educação e busca de informação, $64 \%$ das crianças disseram ter realizado pesquisas online para fazer trabalhos escolares e $46 \%$ por curiosidade ou vontade própria (CETIC.BR, 2020). O uso de rede sociais foi indicado por apenas $28 \%$ das crianças dessa idade, mas não foi possível achar dados sobre se o YouTube seria ou não considerado uma rede social pelas crianças ou pelos próprios formuladores da pesquisa. Uma hipótese é de que as crianças (ou os formuladores) não estão considerando o YouTube como uma rede social, pois $82 \%$ delas relatam assistir a vídeos, programas, filmes ou séries online mais de uma vez por dia - ou seja, caso considerassem o YouTube como rede social, a porcentagem de uso de redes provavelmente seria mais alta.

Em uma ampla pesquisa (LIVINGSTONE et al., 2019) realizada de forma comparativa em três países (Bulgária, Chile e África do Sul), foi percebido que há uma certa "escada" na participação das crianças online, significando que as mais novas, de 9 a 11 anos fazem menos atividades online do que as de 12 a 14 anos e menos ainda do que as de mais de 15 anos. Tanto na Bulgária quanto no Chile, as atividades preferidas das crianças de 9 a 11 anos são assistir a vídeos (83\% e 81\% respectivamente) e jogar jogos online (78\% e $77 \%$ respectivamente). Já na África do Sul, apenas $25 \%$ das crianças dessa idade relataram assistir a vídeos semanalmente. Uma hipótese que as pesquisadoras apontam para explicar esse resultado é o fato de as crianças do país terem mais dificuldade em acessar uma internet rápida, o que dificultaria atividades que consomem muito do pacote de dados.

No Brasil, 43\% das famílias de classes DE que têm acesso à internet dizem usar exclusivamente o wifi, enquanto $13 \%$ usam exclusivamente o $3 \mathrm{G}$ e o $4 \mathrm{G}$ e $36 \%$ 
das famílias dessa classe utilizam tanto os dados de internet móvel quanto o wifi (CETIC.BR, 2020). Talvez essa possibilidade de acesso via wifi por $79 \%$ da população das classes mais baixas explique a alta frequência (82\%) em que as crianças assistem a vídeos online, mesmo em um país com condições de acesso desiguais.

Livingstone (2020) ressalta que as pesquisas das últimas décadas, tanto no Brasil quanto fora, vêm apontando que quanto mais participação online a criança tem, mais em contato com as oportunidades ela está, mas, ao mesmo tempo, também mais exposta aos riscos. Assim, a autora defende que quando se trata de crianças na internet, o movimento sempre deve ser de maximizar as oportunidades a que ela tem acesso ao mesmo tempo em que se minimiza os possíveis riscos e danos. Esse movimento de maximizar oportunidades e minimizar riscos basicamente depende de: letramento midiático nas escolas, conteúdos positivos públicos sem marketing por trás, responsáveis confiantes e não apenas restritivos e efetiva regulação pelo estado (LIVINGSTONE, 2020).

Em relação aos riscos e danos que a participação online pode gerar, os dados da pesquisa do TIC KIDS Brasil 2020 apontam que: 22\% das crianças e adolescentes de 11 a 17 anos relataram ter tido contato nos últimos 12 meses com cenas de violência ou com muito sangue, $15 \%$ com conteúdos apontando formas de emagrecer, $15 \%$ com formas de cometer suicídio, $12 \%$ com formas de machucar a si mesmo e $10 \%$ com experiências ou uso de drogas. Já em relação aos conteúdos sexuais, $15 \%$ das crianças e adolescentes de 9 a 17 anos disseram ter visto na internet imagem ou vídeo de conteúdo sexual e $6 \%$ se sentiram incomodadas após o contato com esse conteúdo. Outro fator questionado é se a criança ou adolescente foi tratado de forma ofensiva na internet, e os números apontam uma maior frequência desse tipo de relato em meninas ( $31 \%$ contra $24 \%$ nos meninos) e em adolescentes mais velhas (37\% nos adolescentes de 15 a 17 anos e $12 \%$ nas crianças de 9 e 10 anos). A discriminação na internet foi testemunhada por $43 \%$ das crianças e adolescentes de 9 a 17 anos, sendo vista por metade delas mais de uma vez por dia e tendo seus principais motivos a cor ou raça, a aparência física da pessoa, o gosto por pessoas do mesmo sexo e a religião.

Livingstone et al. (2014) agruparam os riscos relatados por crianças na internet em três grandes categorias: conteúdo, conduta e contato. O risco de conteúdo pode ser encontrado em sites, imagens, mensagens e se referem principalmente a conteúdos pornográficos e violentos. O risco de conduta em geral é a partir da 
interação de crianças e adolescentes com seus pares, como, por exemplo, os xingamentos e as mensagens agressivas, o cyberbullying ou o compartilhamento de imagens ou mensagens pessoais. Por fim, o risco de contato é realizado principalmente por adultos, como os contatos inapropriados de pedófilos ou outras pessoas estranhas, contas falsas ou tentativas de encontros presenciais.

Nogueira (2016), em sua dissertação de mestrado, optou por acrescentar as categorias de percepção de sexo, risco tecnológico e percepção de violência para classificar os riscos online. Após analisar as respostas de 1.071 crianças brasileiras sobre o que as incomoda na internet, a autora constatou que as mais novas (de 9 a 12 anos) relatam se preocupar mais com agressões verbais e conteúdos de terror, enquanto as adolescentes parecem se incomodar mais com os conteúdos pornográficos.

Outro fator relevante para pensarmos o uso das crianças é em relação à permissividade para o uso da internet. Os dados do TIC KIDS Brasil 2019 apontam que as crianças relatam ter maior permissividade de uso do que os pais ou responsáveis dizem permitir. Por exemplo: 18\% das crianças e adolescentes de 9 a 17 anos dizem poder dar informações pessoais para outras pessoas, enquanto $7 \%$ dos pais ou responsáveis relatam permitir isso. Usar as redes sociais sozinhos é visto como permitido por $70 \%$ das crianças e adolescentes dessa faixa etária, mas apenas $53 \%$ dos responsáveis confirmam essa permissividade, assim como assistir a vídeos, programas, filmes ou séries, que $78 \%$ das crianças afirmam poder e $58 \%$ dos responsáveis dizem deixar. Esse resultado possivelmente aponta para uma falta de conversa, mediação e de regras claras pré-estabelecidas entre adultos e crianças.

Os resultados do TIC KIDS Brasil 2019 também apontam que, quanto maior a escolaridade dos responsáveis, mais eles relatam dar orientações para as crianças sobre o uso da internet. Entre os responsáveis com ensino médio completo ou escolaridade maior: $61 \%$ sentam junto enquanto a criança usa internet, $68 \%$ ajudam em alguma coisa quando ela não entende, $82 \%$ ensinam jeitos de usar a internet de forma segura e $84 \%$ conversam sobre o que fazem na internet. Esses números caem para, respectivamente $48 \%, 33 \%, 68 \%$ e $72 \%$ para responsáveis com escolaridade até o ensino fundamental I. Seria interessante ter esses dados relatados também pelas crianças, para podermos ver qual é a percepção delas acerca dessa mediação parental. 
Como defendido por Livingstone (2020) e Buckingham (2019) o acesso à internet não garante uma participação crítica das crianças no ambiente online. Ambos os autores, referências no assunto, defendem o letramento midiático através da mídia-educação nas escolas, além de políticas públicas que garantam um uso seguro e proveitoso das tecnologias.

Livingstone (2009) defende que maximizar as oportunidades online e pensar em conteúdos positivos na internet é uma questão de direito da criança. Para elaborar sua defesa, a autora aponta para uma série de direitos das crianças em termos legislativos, como, por exemplo, de se expressar de maneira livre, de ter sua privacidade protegida e do direito de receber informações e materiais que as beneficiem socialmente e culturalmente. Usar os direitos das crianças também no mundo digital pode ter como base argumentos sobre vulnerabilidade das crianças ou o fato de elas serem “o futuro na nação", mas esses argumentos esvaziam um pouco a agência da criança e fogem do pensamento da criança como alguém que está aqui e agora, não apenas nas consequências para o futuro (LIVINGSTONE, 2020). Dessa forma, a proposta de Livingstone em olhar a criança como agente pode ser considerada coerente com a concepção de criança e de infância que acreditamos e escolhemos para esse trabalho, já explicitada ao longo da seção 2.1.

Livingstone (2009) propõe uma série de princípios para pautar a relação das crianças com a internet, tendo como base o "Children's Television Charter" (ANNA HOME, 1995). Alguns desse princípios são:

1. Crianças devem ter conteúdos e serviços online de alta qualidade, que são feitos especificamente para elas e que não as explorem. Além de entretê-las, eles devem permitir que as crianças se desenvolvam fisicamente, mentalmente e socialmente em seu potencial máximo

2. Crianças devem escutar, ver e se expressar, expressar sua cultura, linguagem e experiências de vida através de conteúdos e serviços online que afirmem seu senso de self, de comunidade e de pertencimento.

3. Conteúdos e serviços online para crianças devem promover consciência e apreciação de outras culturas em paralelo com o capital cultural da própria criança.

4. Conteúdos e serviços online para crianças devem ter uma vasta opção de conteúdos e gêneros, mas não devem incluir cenas gratuitas de violência e sexo.

(LIVINGSTONE, 2009, p. 13, traduação nossa)

Nessa mesma lógica, Wartella e Jennings (2000) também propõem um conjunto de critérios que deveriam ser levados em consideração quando se está criando novo conteúdo para as crianças. As autoras ressaltam a importância de se fazerem algumas perguntas para refletir sobre aquele conteúdo que está sendo criado, como, 
por exemplo, se é relevante para crianças de diferentes grupos raciais, se apresenta modelos femininos empoderados, se cria ou reforça estereótipos de gêneros ou raça, se é divertido, e se o conteúdo apresenta algo para dizer ou é apenas para vender um produto.

Buckingham (2019) aponta que, no momento em que estamos vivendo, os consumidores têm, online, cada vez mais chances e oportunidades de uso, mas, ao mesmo tempo, as grandes empresas estão cada vez coletando e analisando mais dados desses consumidores. Essas grandes empresas, atualmente, formam um monopólio que basicamente controla todas as plataformas e serviços que são oferecidos. Por outro lado, como ressalta Livingstone (2020), quando se trata das crianças na internet, enfrentamos um grande dilema: ou elas ficam invisíveis online e não conseguimos mapear suas atividades, oportunidades e riscos, ou elas estão sujeitas a essa coleta perversa de dados pelo mercado.

Apesar de a preocupação com as crianças no ambiente online ter se tornado um tópico nas grandes mídias, nas famílias e nas escolas, é importante que as pesquisas acadêmicas não caiam no alarmismo, determinismo e no pânico que há em torno desse assunto no senso comum (LIVINGSTONE, 2020). Sobre isso, Livingstone (2020) relembra que as crianças ainda amam jogar bola no parque e brincar com os colegas, e que o maior perigo que elas enfrentam ainda está no mundo offline, como por exemplo nas situações de pobreza, discriminação e abusos. A autora ainda destaca que a internet apenas deixou mais explícito como os direitos das crianças não vêm sendo cumpridos nas últimas décadas: o cyberbullying atraiu a atenção de todos, mesmo o bullying tendo sido ignorado por anos nas escolas; a educação sexual é um tópico do qual os adultos fogem, mas que agora estão preocupados por conta da pornografia online; a culpa da saúde mental fragilizada seria mesmo da internet ou a internet serve apenas para divulgar o pedido de ajuda das crianças e jovens que estão sofrendo (LIVINGSTONE, 2020)? Esses são alguns questionamentos importantes de serem levantados quando pensamos no assunto.

É também necessário observar de que forma as crianças estão se apropriando dos espaços online, nessa perspectiva de que não são passivas em seus usos, mas reinterpretam e ressignificam tais espaços. Sarmento e Barros (2008) observaram como as crianças se apropriam de certos aspectos da internet e constatam que, apesar de esse ser um espaço de produção exclusivamente feito pelos adultos, elas se apropriam e incorporam criativamente modos únicos de pensar e agir naquele 
espaço. Na época em que foi realizada a pesquisa, eram raros os sites ou jogos que foram criados pelas próprias crianças. Atualmente, no entanto, o YouTube conta com um expressivo número de canais feitos e protagonizados por crianças, e isso será discutido na próxima seção.

Becker (2017) encontrou em pesquisa recente, realizada a partir de um questionário online com 46 crianças de 5 a 12 anos, que aproximadamente 50\% delas acreditam que o entretenimento e a diversão são vantagens de ter a tecnologia digital em seus cotidianos. O desenvolvimento de habilidades foi citado por $33 \%$ das crianças e o estímulo à interação/conexão por $10 \%$ delas. Já os respondentes adultos, 198 no total, acreditam que o desenvolvimento de habilidades é a grande vantagem da tecnologia, sendo esse fator relatado por $69 \%$ deles. Apenas $8 \%$ citaram o acesso à informação como vantagem e $8 \%$ mencionaram esse ser um espaço de diversão segura no cotidiano das crianças. Em uma segunda fase da pesquisa, 9 crianças-investigadoras levantaram hipóteses sobre esses dados. Becker (2017) explica que crianças acreditam que os adultos não consideram que a brincadeira com a tecnologia digital possa ter como vantagem simplesmente divertir e entreter, pois isso é visto por eles como uma perda de tempo. Seria como se só fosse uma vantagem se de fato alguma habilidade cognitiva estivesse sendo desenvolvida, ou algum conteúdo visto como escolar estivesse sendo aprendido, sendo que as crianças relatam, sim, aprender diversas curiosidades e fatos por meio da internet (BECKER, 2017).

Essa pesquisa foi importante para demonstrar como o olhar do adulto é diferente do olhar da criança em relação à tecnologia. O foco para as crianças é o brincar, e a tecnologia é um dos muitos artefatos que elas estão utilizando para isso, principalmente associada à brincadeira entre pares - seja no âmbito virtual ou não (BECKER, 2017). Dessa forma, Becker aponta que é importante perceber os usos lúdicos e criativos que as crianças estão fazendo das tecnologias, não caindo em um discurso raso de apenas rotulá-las como algo que está "destruindo" a infância, fala que muitas vezes está associada a um sentimentalismo de uma infância em um tempo em que as tecnologias digitais não faziam parte das culturas infantis. Apresentarei a seguir os estudos que abordam especificamente as crianças e a plataforma do YouTube. 


\section{3}

\section{Os estudos sobre as crianças e o YouTube}

Como já relatado anteriormente, os estudos envolvendo as crianças e a plataforma do YouTube ainda são recentes na literatura, tanto no Brasil quanto em outros países. Para demostrar isso e apresentar o que está sendo produzido, optamos por realizar um levantamento dos artigos empíricos encontrados nas principais plataformas de buscas e organizá-los de acordo com: 1) o tipo de trabalho (monografias, dissertações, teses, artigos e apresentações em congressos); 2) as temáticas pesquisadas e 3) a metodologia utilizada.

Para realizar essa revisão empírica, utilizamos as plataformas Google Acadêmico, Scielo, Portal da Capes e ERIC. Inicialmente, procuramos trabalhos que abordassem especificamente o YouTube, e utilizamos o próprio descritor youtube sozinho, para ter uma noção do que estava sendo produzido academicamente em relação à plataforma. Encontramos muitos trabalhos na área da Saúde e da Tecnologia e Comunicação.

Em seguida, pesquisamos por youtube + criança, youtube + infância e seus equivalentes em inglês, como mostrado no Quadro 1. Adaptamos os termos utilizados e os filtros de acordo com cada uma das plataformas de buscas. No quadro abaixo, mostramos quantos artigos encontrei em cada uma das plataformas, e, dentre esses, quantos estavam relacionados especificamente às crianças e à plataforma do YouTube.

Pesquisamos primeiramente no Google Acadêmico, plataforma onde encontrei o maior número de artigos, e, posteriormente, nas outras plataformas, eliminando aqueles artigos que já tinham sido achados anteriormente. É importante ressaltar também que, no Google Acadêmico, a quantidade de resultados que aparece é enorme, apesar de poucos corresponderem ao tema desejado. Então, após filtrar por ano e mudar as palavras-chaves, optamos por olhar as 50 primeiras páginas de buscas, totalizando 500 resultados de artigos. Na maior parte das plataformas, os resultados relevantes estavam nas primeiras páginas, sendo as outras com resultados que não correspondiam ao tema das crianças e do YouTube. 
Quadro 1 - Quadro de levantamento de textos nas plataformas

\begin{tabular}{|c|c|c|c|c|c|}
\hline Base de Dados & Descritores & $\begin{array}{c}\text { Quantidade } \\
\text { Total }\end{array}$ & Filtro & $\begin{array}{l}\text { Quantidade } \\
\text { com filtro }\end{array}$ & $\begin{array}{l}\text { Relevantes } \\
\text { para o tema }\end{array}$ \\
\hline \multirow{5}{*}{$\begin{array}{l}\text { Google Acadê- } \\
\text { mico }\end{array}$} & youtube & 4.470 .000 & $\begin{array}{l}\text { data: últi- } \\
\text { mos } 5 \\
\text { anos }\end{array}$ & 956.000 & - \\
\hline & $\begin{array}{c}\text { youtube + } \\
\text { criança }\end{array}$ & 27.200 & $\begin{array}{l}\text { data: últi- } \\
\text { mos } 5 \\
\text { anos }\end{array}$ & 16.300 & 25 \\
\hline & $\begin{array}{l}\text { youtube + } \\
\text { infância }\end{array}$ & 24.500 & $\begin{array}{l}\text { data: últi- } \\
\text { mos } 5 \\
\text { anos }\end{array}$ & 15.900 & - \\
\hline & $\begin{array}{c}\text { youtube + } \\
\text { children }\end{array}$ & 945.000 & $\begin{array}{l}\text { data: últi- } \\
\text { mos } 5 \\
\text { anos }\end{array}$ & 141.000 & - \\
\hline & $\begin{array}{l}\text { youtube + } \\
\text { childhood }\end{array}$ & 422.000 & $\begin{array}{l}\text { data: últi- } \\
\text { mos } 5 \\
\text { anos }\end{array}$ & 42.600 & - \\
\hline \multirow{5}{*}{ Scielo } & youtube & 156 & - & - & - \\
\hline & $\begin{array}{c}\text { youtube + } \\
\text { criança }\end{array}$ & 0 & - & - & - \\
\hline & $\begin{array}{c}\text { youtube + } \\
\text { infância }\end{array}$ & 2 & - & - & - \\
\hline & $\begin{array}{l}\text { youtube + } \\
\text { children }\end{array}$ & 12 & - & - & 1 \\
\hline & $\begin{array}{l}\text { youtube + } \\
\text { childhood }\end{array}$ & 2 & - & - & - \\
\hline \multirow{2}{*}{$\begin{array}{l}\text { Catálogo de Te- } \\
\text { ses e Disserta- } \\
\text { ções da Capes }\end{array}$} & \multirow[b]{2}{*}{ youtube } & \multirow[b]{2}{*}{464} & $\begin{array}{l}\text { área: edu- } \\
\text { cação }\end{array}$ & 32 & 2 \\
\hline & & & $\begin{array}{l}\text { área: co- } \\
\text { munica- } \\
\text { ção }\end{array}$ & 118 & 6 \\
\hline \multirow{3}{*}{ Portal da Capes } & youtube & 96.566 & - & - & - \\
\hline & $\begin{array}{l}\text { youtube }+ \\
\text { criança }\end{array}$ & 67 & - & - & 1 \\
\hline & $\begin{array}{l}\text { youtube + } \\
\text { infância }\end{array}$ & 214 & - & - & 2 \\
\hline \multirow{3}{*}{ ERIC } & youtube & 620 & - & - & 2 \\
\hline & $\begin{array}{c}\text { youtube + } \\
\text { children }\end{array}$ & 57 & - & - & 1 \\
\hline & $\begin{array}{l}\text { youtube + } \\
\text { childhood }\end{array}$ & 13 & - & - & - \\
\hline & & & & & 40 \\
\hline
\end{tabular}

Fonte: Elaboração da autora 
Além dos 40 artigos encontrados nas plataformas, essa revisão conta com mais 3 artigos que foram encontrados por outros meios, como indicação de pesquisadoras ou referências bibliográficas de outros trabalhos, e um livro que relata uma pesquisa empírica também relevante para a temática. Assim, utilizamos um total de 44 trabalhos para compor esse levantamento. Ressalta-se aqui que privilegiamos os trabalhos realizados no Brasil, optando por um recorte cultural específico, mas não excluímos do levantamento algumas pesquisas realizadas em outros países que podem complementar os achados brasileiros ou até mesmo ser usadas para comparar resultados.

Em relação ao tipo de texto, os 44 trabalhos podem ser divididos da seguinte forma: 14 artigos publicados em revistas acadêmicas, 11 artigos publicados em anais de eventos, 9 dissertações de mestrado, 5 trabalhos de conclusão de curso, 3 teses de doutorado, 1 relatório e 1 livro. O Quadro 2 abaixo mostra a distribuição das fontes.

Quadro 2 - Quadro de levantamento por tipos de textos

\begin{tabular}{|c|c|c|}
\hline Tipo de trabalho & $\begin{array}{l}\text { Quanti- } \\
\text { dade }\end{array}$ & Trabalhos \\
\hline $\begin{array}{l}\text { Artigos publicados } \\
\text { em revistas acadê- } \\
\quad \text { micas }\end{array}$ & 14 & $\begin{array}{l}\text { TUR-VIÑES, V.; NÚÑEZ-GÓMEZ, P.; GONZÁLEZ-RÍO, } \\
\text { 2018; LÓPEZ-VILLAFRANCA, P. et al., 2019; BRAGA- } \\
\text { GLIA, A. P.; FERREIRA, A. L. do N., 2016; MELO, D. R. } \\
\text { De; GUIZZO, B. S., 2019; TOMAZ, R., 2017; MARTÍNEZ, } \\
\text { C.; OLSSON, T., 2019; MARÔPO, L.; SAMPAIO, I. V.; } \\
\text { MIRANDA, N. P. de., 2018; RENÉS ARELLANO, P.; } \\
\text { GOZÁLVEZ PÉREZ, V.; BERLANGA FERNÁNDEZ, I., } \\
\text { 2020; DEWI, S. K. S. M. D. H., 2018; ARAN-RAMSPOT, } \\
\text { S.; FEDELE, M.; TARRAGO, A., 2018; SATLER, L. L.; } \\
\text { CARRIJO, A. J., 2019; MORAES, H. J. P., 2017; EI- } \\
\text { CKHOFF, C.; DE VRIES, A. P., 2010; CASTRO, G. G. S.; } \\
\text { ANDRADE, M. 2020. }\end{array}$ \\
\hline $\begin{array}{l}\text { Artigos publicados } \\
\text { em anais de con- } \\
\text { gressos }\end{array}$ & 11 & $\begin{array}{l}\text { LEMES, B. M.; LOPES, T. A. C.; RABAIOLLI, J., 2017; } \\
\text { JORGE, G. M. dos S., 2018; GUEDES, W.; VIEIRA, P.; } \\
\text { CALAZANS, F., 2017; LEÃO, D.; PRESSLER, N., 2017; } \\
\text { MCROBERTS, S. et al., 2016; TOMÉ, H. L.; BORGES, G., } \\
\text { 2019; CORRÊA, L., 2015; MONTEIRO, M. C. S., 2018; } \\
\text { BUZZI, M., 2012; RIBEIRO, A. L. F.; LORDELO, L. da } \\
\text { R., 2019; PAPADAMOU, K. et al., } 2020\end{array}$ \\
\hline $\begin{array}{l}\text { Dissertações de } \\
\text { mestrado }\end{array}$ & 9 & $\begin{array}{l}\text { OLIVEIRA, R. A. D. C., 2019; FERREIRA, A. L. do N., } \\
\text { 2017; OLIVEIRA, J. D. S., 2018; MELO, D. R. de., 2018; } \\
\text { BALBO PAPINI, A., 2016; PASSOS, G. dos., 2016; RI- } \\
\text { BEIRO, A. L. F., 2020; DALETHESE, T. R., 2017; BE- } \\
\text { ZERRA, L. D. G. L. D. C., } 2018\end{array}$ \\
\hline $\begin{array}{l}\text { Trabalhos de con- } \\
\text { clusão de curso }\end{array}$ & 5 & $\begin{array}{l}\text { BENN, J. F., 2019; SILVA, T. T. DA., 2019; GIRÃO, L. V. } \\
\text { D. O., 2018; ARAÚJO, D. K. C., 2019; LUZ, M. D. DA., } \\
2018\end{array}$ \\
\hline
\end{tabular}




\begin{tabular}{|c|c|c|}
\hline Teses de doutorado & 3 & $\begin{array}{c}\text { SANTOS, J. N. DOS., 2018; TOMAZ, R., 2017; MON- } \\
\text { TEIRO, M. C. S., 2018; }\end{array}$ \\
\hline Relatório & 1 & CORREAA, L., 2016 \\
\hline Livro & 1 & LANGE, P. G., 2014 \\
\hline \multicolumn{2}{|c|}{ Fonte: Elaboração da autora } \\
\hline
\end{tabular}

É importante ressaltar também como essa se mostra ser uma temática nova na área acadêmica, pois, apesar do grande número de resultados encontrados nas plataformas de buscas, poucos se encaixam no recorte da relação das crianças com o YouTube. No gráfico abaixo podemos ver a distribuição por ano desses 44 trabalhos encontrados:

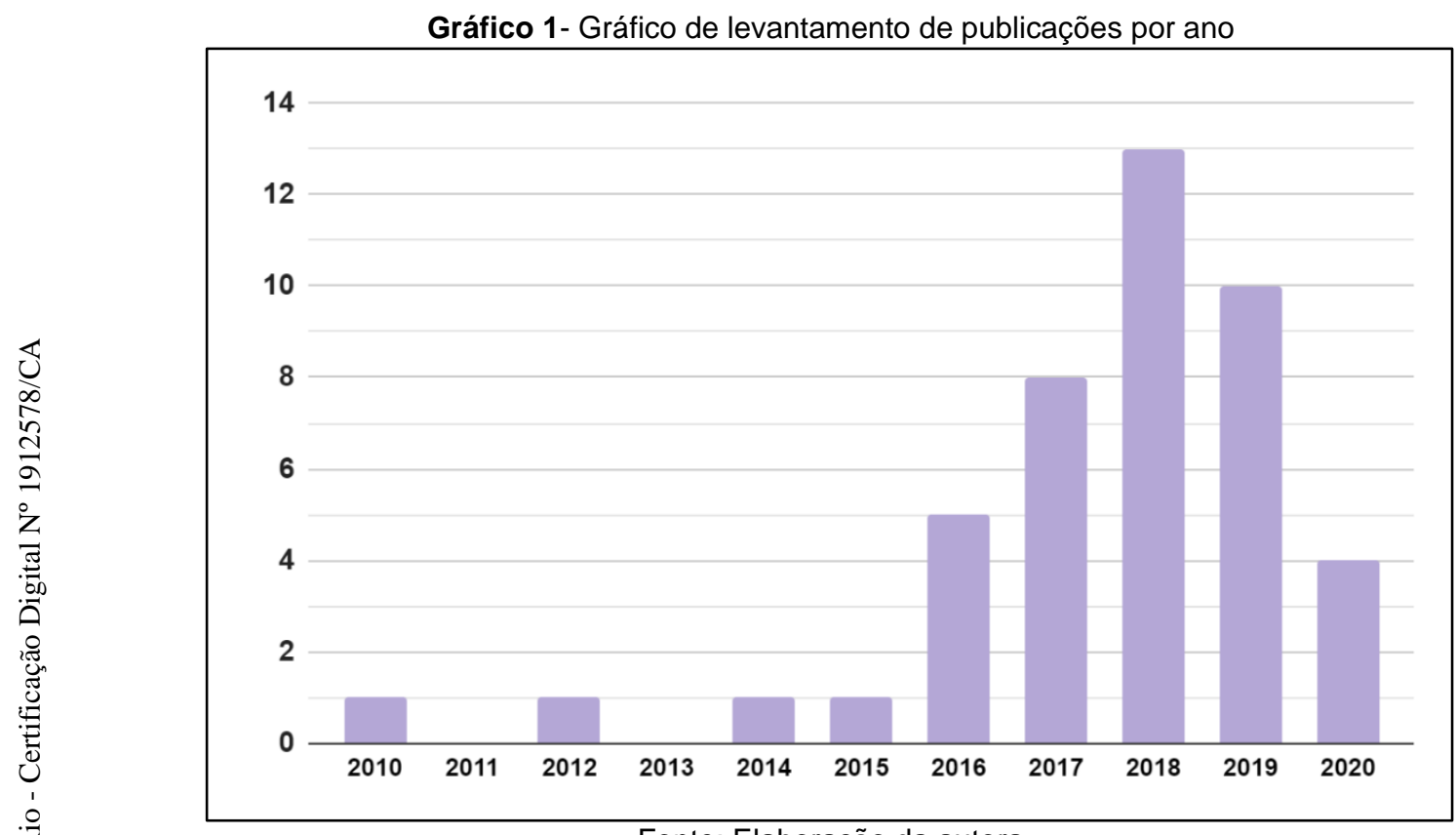

Fonte: Elaboração da autora

A plataforma do YouTube foi criada em 2005, mas o primeiro artigo encontrado que aborda a temática das crianças no YouTube foi apenas em 2010. Ainda assim, esse artigo, assim como o de 2012 e o livro de 2014 são internacionais. No Brasil, o primeiro trabalho dedicado a pensar nos conteúdos que as crianças assistem na plataforma foi o de Corrêa (2015). A partir de 2016, as produções se intensificaram consideravelmente, atingindo seu pico em 2018.

A distribuição acima e a quantidade de trabalhos de conclusão de curso, dissertações e teses recentes que vêm sendo produzidas, e que ainda não se transformaram em artigos acadêmicos, nos mostra como essa é uma temática que ainda está em crescimento. 
Em relação às temáticas desses trabalhos, optamos por separar em 6 grandes temas que são os predominantes nas pesquisas, conforme mostrado no Quadro 3. A temática mais frequente que aparece nos textos é em relação aos youtubers mirins, ou seja, crianças que são produtoras de conteúdos na plataforma. Em segundo lugar, aparecem os trabalhos que abordam especificamente as questões de publicidade e/ou incentivo ao consumismo nos vídeos do YouTube. Essas duas temáticas mais frequentes se entrelaçam algumas vezes, por isso alguns textos estão repetidos em ambas as categorias. Em segundo lugar, temos as duas temáticas que mais se aproximam desse trabalho que estou construindo, que são as pesquisas que focam especificamente nos conteúdos a que as crianças assistem, tendo como objetivo mapear e/ou discutir sobre os conteúdos, e as pesquisas que se propõe a explorar e discutir as culturas infantis no YouTube, abordando os usos e sentidos que as crianças atribuem à plataforma. Por último, existem trabalhos que abordam as influências e/ou impactos que o YouTube pode ter na vida das crianças e trabalhos internacionais em que o foco são os conteúdos inapropriados da plataforma. No Quadro 3, é possível ver essa separação dos artigos por temáticas predominantes.

Quadro 3 - Quadro de levantamento por temática dos textos

\begin{tabular}{|c|c|c|}
\hline $\begin{array}{c}\text { Temática do } \\
\text { trabalho }\end{array}$ & Quantidade & Trabalhos \\
\hline $\begin{array}{c}\text { Youtubers Mi- } \\
\text { rins }\end{array}$ & 28 & \begin{tabular}{|l} 
TUR-VIÑES, V.; NÚÑEZ-GÓMEZ, P.; GONZÁLEZ-RÍO, M. \\
J., 2018; TOMÉ, H. L.; BORGES, G., 2019; LÓPEZ-VILLA- \\
FRANCA, P. et al., 2019; LEMES, B. M.; LOPES, T. A. C.; RA- \\
BAIOLLI, J., 2017; BRAGAGLIA, A. P.; FERREIRA, A. L. do \\
N., 2016.; OLIVEIRA, R. A. D. C., 2019; SANTOS, J. N. DOS., \\
2018; JORGE, G. M. dos S., 2018; GUEDES, W.; VIEIRA, P.; \\
CALAZANS, F., 2017; BENN, J. F., 2019; FERREIRA, A. L. do \\
N., 2017; OLIVEIRA, J. D. S., 2018; MELO, D. R. De; \\
GUIZZO, B. S., 2019; MELO, D. R. de., 2018; BALBO PAPINI, \\
A., 2016; TOMAZ, R., 2017; SILVA, T. T. DA., 2019; LEÃO, \\
D.; PRESSLER, N., 2017; MARTÍNEZ, C.; OLSSON, 2019; \\
MCROBERTS, S. et al., 2016; MCROBERTS, S. et al., 2016; \\
CORRÊA, L., 2015; TOMAZ, R., 2017; MARÔPO, L.; SAM- \\
PAIO, I. V.; MIRANDA, N. P. de., 2018; GIRÃO, L. V. D. O., \\
2018; DALETHESE, T. R., 2017; LANGE, P. G., 2014; CAS- \\
TRO, G. G. S.; ANDRADE, M. 2020.
\end{tabular} \\
\hline $\begin{array}{c}\text { Publicidade / } \\
\text { Consumo }\end{array}$ & 14 & $\begin{array}{l}\text { LÓPEZ-VILLAFRANCA, P. et al., 2019; MONTEIRO, M. C. } \\
\text { S., 2018; MONTEIRO, M. C. S., } 2018 \text { (2); LEMES, B. M.; LO- } \\
\text { PES, T. A. C.; RABAIOLLI, J., 2017; BRAGAGLIA, A. P.; } \\
\text { FERREIRA, A. L. do N., 2016; OLIVEIRA, R. A. D. C., 2019; } \\
\text { FERREIRA, A. L. do N., 2017; OLIVEIRA, J. D. S., 2018; } \\
\text { BALBO PAPINI, A., 2016; SILVA, T. T. DA., 2019; LEÃO, D.; } \\
\text { PRESSLER, N., 2017; TUR-VIÑES, V.; NÚÑEZ-GÓMEZ, P.; } \\
\text { GONZÁLEZ-RÍO, M., 2018; MARÔPO, L.; SAMPAIO, I. V.; }\end{array}$ \\
\hline
\end{tabular}




\begin{tabular}{|c|c|c|}
\hline & & MIRANDA, N. P. de., 2018; CASTRO, G. G. S.; ANDRADE, \\
M. 2020. \\
$\begin{array}{c}\text { Conteúdos as- } \\
\text { sistidos }\end{array}$ & 5 & $\begin{array}{c}\text { ARAÚJO, D. K. C., 2019; CORREA, L., 2016; RENÉS AREL- } \\
\text { LANO, P.; GOZÁLVEZ PÉREZ, V.; BERLANGA FER- } \\
\text { NÁNDEZ, I., 2020; LUZ, M. D. DA., 2018; PASSOS, G. dos., } \\
\text { 2016. }\end{array}$ \\
\hline $\begin{array}{c}\text { Culturas In- } \\
\text { fantis }\end{array}$ & 4 & $\begin{array}{c}\text { RIBEIRO, A. L. F., 2020; RIBEIRO, A. L. F.; LORDELO, L. da } \\
\text { R., 2019; SATLER, L. L.; CARRIJO, A. J., 2019; MORAES, H. } \\
\text { J. P., 2017. }\end{array}$ \\
\hline $\begin{array}{c}\text { Impactos e in- } \\
\text { fluências do } \\
\text { YT }\end{array}$ & 3 & $\begin{array}{c}\text { DEWI, S. K. S. M. D. H., 2018; ARAN-RAMSPOTT, S.; FE- } \\
\text { DELE, M.; TARRAGÓ, A., 2018; BEZERRA, L. D. G. L. D. C., } \\
\text { 2018 }\end{array}$ \\
\hline $\begin{array}{c}\text { Conteúdos } \\
\text { Inapropriados }\end{array}$ & 3 & $\begin{array}{c}\text { PAPADAMOU, K. et al., 2020; EICKHOFF, C.; DE VRIES, A. A. } \\
\text { P., 2010; BUZZI, M., 2012 }\end{array}$ \\
\hline
\end{tabular}

Fonte: Elaboração da autora

Em relação às metodologias utilizadas nas pesquisas, a grande predominância é da abordagem netnográfica e/ou análise do conteúdo dos vídeos postados no YouTube. São 28 pesquisas que utilizam esse tipo de metodologia, em contraposição a apenas 11 que optam pelas entrevistas ou grupos focais com as crianças produtoras e/ou espectadoras dos vídeos do YouTube. As outras 5 pesquisas utilizam métodos exclusivamente quantitativos, sendo a maioria delas com base em coleta de dados realizada a partir de questionários fechados. Esse levantamento mostra uma lacuna nas pesquisas que contemplam as vozes das crianças para além daquilo que elas estão relatando nos vídeos.

Vamos nos debruçar agora sobre alguns dos achados mais relevantes desses estudos que vêm sendo realizados, passando de forma mais rápida primeiramente por aqueles que focam na questão da publicidade no YouTube, depois indo para a temática dos youtubers mirins, e, por fim, aprofundando nos achados de pesquisas que se assemelham mais à temática deste estudo.

\subsection{1}

A publicidade e as crianças 
A preocupação com as publicidades encontradas na internet é o grande foco das pesquisas dedicadas em estudar as crianças na plataforma do YouTube; principalmente as pesquisas nas áreas de Marketing e de Direito, que apontam que crianças ganham dinheiro para fazer propaganda de grandes marcas, possivelmente contribuindo para um maior consumismo infantil, ao fazer a associação entre o consumo do produto com o sentimento de felicidade (BRAGAGLIA; FERREIRA, 2016; FERREIRA, 2017).

Lemes, Lopes e Rabaiolli (2017) e Papini (2016) ressaltam que nem sempre há uma clareza sobre a criança estar ou não sendo paga em dinheiro para fazer propaganda daquele produto, muitas vezes mencionado como um "presente" que a marca enviou. Além disso, em geral, não são encontrados nos vídeos sinalizações explícitas de publicidade (LEMES; LOPES; RABAIOLLI, 2017; OLIVEIRA, 2019), algo que é mais comum nos canais dos youtubers adultos. Oliveira (2018) argumenta que as marcas estão fortemente presentes no cotidiano das crianças, e, por isso, muitas vezes aparecem de uma forma natural nos vídeos, pois estamos todos inseridos na lógica capitalista. Entretanto, o autor ressalta que propagandas realizadas de forma velada vão contra o regimento da CONAR e não podem ser vistas como práticas éticas, devendo ser mais bem fiscalizadas. O grande problema é que as regras em relação às publicidades direcionadas para as crianças em canais do YouTube ainda não são claras, o que dificulta a regulação das mesmas (PAPINI, 2016).

Maria Clara Sidou Monteiro (2018) aponta que os vídeos produzidos por youtubers que apresentam publicidade de experiência (quando mostram produtos ao longo do vídeo de forma mais natural, contando seu relato) são mais aceitos pelas crianças do que as publicidades tradicionais, e também são mais persuasivos, por conta da relação de afetividade e confiança que se estabelece entre quem está assistindo e quem está por trás das câmeras - a linha entre o que é publicidade e o que é entretenimento fica mais tênue.

Analisando os vídeos dos youtubers mirins, os pesquisadores vêm identificando que, muitas vezes, as crianças brincam com os produtos recebidos frente às câmeras, ora de forma natural e espontânea, ora seguindo um roteiro mais estruturado e alterando seu tom de voz (BRAGAGLIA; FERREIRA, 2016; FERREIRA, 2017; OLIVEIRA, 2018; TUR-VIÑES; NÚÑEZ-GÓMEZ; GONZÁLEZ-RÍO, 2018; LÓPEZ-VILLAFRANCA et al., 2019). Leão e Pressler (2017) apontam para 
uma diferente relação com a marca, que agora é apresentada de uma maneira mais próxima, como uma amiga que enviou um presente para a criança brincar, tornando a publicidade muito mais "real" de certa forma.

\subsection{2}

\section{As crianças como youtubers mirins}

Outras pesquisas que investigam os youtubers mirins vão além da preocupação com a publicidade nos canais infantis e o possível incentivo ao consumismo, visando explorar os modos com que essas crianças estão se apropriando do espaço do YouTube. Antes de entrarmos nas pesquisas em si, é importante traçarmos um breve perfil de quem são os youtubers mirins de sucesso atualmente. Após analisarmos a lista dos 250 youtubers com mais inscritos do site Social Blade (SOCIAL BLADE, 2020) ${ }^{6}$ e montarmos o quadro 4, pudemos constatar que: 17 canais são de youtubers mirins (considerando crianças de até 13 anos), sendo 12 canais de meninas, 4 de meninos e 1 de um casal de irmãos. Além da predominância de crianças do gênero feminino, também chama a atenção que todas as crianças aparentam ser brancas e de classes sociais mais elevadas. O canal da MC Divertida chama atenção por ser o único da lista protagonizado por uma criança com nanismo, fugindo do padrão normativo dos outros canais. Esse perfil dos youtubers mirins de sucesso se reflete nas pesquisas, justamente por muitas vezes os pesquisadores selecionarem para a análise os canais mais famosos da plataforma.

Quadro 4 - Quadro de youtubers mirins de maior número de inscritos no Brasil

\begin{tabular}{|c|c|c|c|}
\hline $\begin{array}{c}\text { Posição na lista dos } 250 \text { ca- } \\
\text { nais com mais inscritos }\end{array}$ & Nome do canal & $\begin{array}{c}\text { Quantidade de } \\
\text { inscritos }\end{array}$ & $\begin{array}{c}\text { IDADE DA CRI- } \\
\text { ANÇA }\end{array}$ \\
\hline $9^{\circ}$ & Maria Clara \& JP & $22.9 \mathrm{M}$ & 8 e 11 anos \\
\hline $10^{\circ}$ & Valentina Pontes & $20.7 \mathrm{M}$ & 8 anos \\
\hline $29^{\circ}$ & $\begin{array}{c}\text { Planeta das } \text { Gê- } \\
\text { meas }\end{array}$ & $13.7 \mathrm{M}$ & 12 anos \\
\hline $46^{\circ}$ & Bela Bagunça & $11.9 \mathrm{M}$ & 13 anos \\
\hline $52^{\circ}$ & Juliana Baltar & $11.1 \mathrm{M}$ & 13 anos \\
\hline $81^{\circ}$ & $\begin{array}{c}\text { Brincando com } o \\
\text { Rafael }\end{array}$ & $9.1 \mathrm{M}$ & $\begin{array}{c}\text { aproximadamente } \\
5,6 \text { anos }\end{array}$ \\
\hline
\end{tabular}

\footnotetext{
${ }^{6}$ Acessado em 20 de outubro de 2020.
} 


\begin{tabular}{|c|c|c|c|}
\hline $84^{\circ}$ & $\begin{array}{c}\text { Crescendo com } \\
\text { Luluca }\end{array}$ & $8.95 \mathrm{M}$ & 11 anos \\
\hline $110^{\circ}$ & BEL & $7.68 \mathrm{M}$ & 13 anos \\
\hline $111^{\circ}$ & Isaac do VINE & $7.66 \mathrm{M}$ & 10 anos \\
\hline $123^{\circ}$ & Mundo da Vivi & $7.2 \mathrm{M}$ & 13 anos \\
\hline $131^{\circ}$ & MC Divertida & $7.02 \mathrm{M}$ & 11 anos \\
\hline $139^{\circ}$ & Julia MineGirl & $6.91 \mathrm{M}$ & 13 anos \\
\hline $159^{\circ}$ & $\begin{array}{c}\text { Família Paulinho } \\
\text { e Toquinho }\end{array}$ & $6.32 \mathrm{M}$ & $10 \mathrm{e} 6$ anos \\
\hline $161^{\circ}$ & $\begin{array}{c}\text { Hoje é dia de Ma- } \\
\text { rias }\end{array}$ & $6.3 \mathrm{M}$ & 10 e11 anos \\
\hline $203^{\circ}$ & Sarah de Araújo & $4.41 \mathrm{M}$ & 8 anos \\
\hline $228^{\circ}$ & Bia Lobo & $4.97 \mathrm{M}$ & 8 anos \\
\hline $233^{\circ}$ & Piero Start & $4.92 \mathrm{M}$ & 8 anos \\
\hline
\end{tabular}

Fonte: Elaboração da autora com base nas informações do site Social Blade, acessado em novembro de 2020

Maropô, Sampaio e Miranda (2018) optaram por investigar 4 canais de meninas youtubers que se encaixam nesse recorte mencionado anteriormente. $\mathrm{Na}$ época da pesquisa, em 2016, os canais escolhidos eram os maiores canais protagonizados por meninas de até 12 anos no YouTube. Após uma criteriosa seleção de corpus de vídeos, foram observados de maneira qualitativa os aspectos relacionados aos conteúdos dos vídeos, à comunicação mercadológica e às práticas das youtubers. Os achados apontam para uma cultura comum compartilhada entre as 4 youtubers, principalmente no que se refere aos formatos e temáticas dos vídeos. A brincadeira é apontada como eixo central das produções das youtubers mirins, assim como foi constatado nos trabalhos de Tomaz (2017), Girão (2018) e Benn (2019). Apesar de o lúdico estar fortemente presente, Maropô, Sampaio e Miranda (2018) ressaltam uma padronização nos tipos de brincadeiras, como, por exemplo, através dos formatos de desafios ou encenações. Para as youtubers pesquisadas, o brincar parece vir antes do ganhar, sem que haja um incentivo a competitividade nos vídeos analisados. Outro aspecto presente nas produções são as temáticas que apresentam morais com valores e/ou ensinamentos, como por exemplo os ciúmes entre irmãos e o bullying.

Em relação ao gênero, Maropô, Sampaio e Miranda (2018) observaram performances de feminilidades emergentes nos vídeos das youtubers mirins, que compartilham suas vidas de modos confessionais, incluindo suas rotinas de moda, 
beleza e decoração. As autoras ressaltam: "Esta valorização da intimidade produz discursos que se projetam como autênticos e que são capazes de promover a identificação das youtubers como modelos perante os seus pares e consequentemente como influenciadoras para hábitos de consumo" (MARÔPO; SAMPAIO; MIRANDA, 2018, p. 192).

Esse compartilhamento de rotinas é encarado de uma forma mais crítica por Jorge (2018), que constata a partir de sua pesquisa que as youtubers mirins reproduzem em seus vídeos estereótipos de uma sociedade machista, sexista e racista. A autora aponta nos vídeos as reflexões de violências simbólicas a que as mulheres são submetidas, principalmente a partir das frequentes temáticas de maternidade, compras, maquiagem e beleza, onde as meninas se comportam como "mini adultas". É comum que as meninas se apresentem nos vídeos a partir de um certo padrão de comportamento e vestimenta, utilizando acessórios, roupas arrumadas e maquiagem (TOMAZ, 2017; SILVA, 2019). Benn (2019) acrescenta nessa discussão de gênero os vídeos em que a temática central é a conquista de meninos, nos quais as youtubers mirins enfatizam precisar estarem bonitas para serem notadas por eles, novamente reproduzindo os estereótipos vistos em nossa sociedade.

Ainda em relação aos estereótipos, as pesquisas ressaltam uma categoria de sucesso no YouTube, que consiste em vídeos nos quais se comparam explicitamente dois extremos, como por exemplo "menina comportada versus menina funkeira" e até mesmo "ricos versus pobres". Apresentados como uma simples brincadeira que não visa desrespeitar ninguém, os vídeos contêm narrativas que reforçam estereótipos de gênero e de classe social de forma bastante evidente (JORGE, 2018; ARAÚJO, 2019; BENN, 2019; TOMÉ; BORGES, 2019).

O recorte racial, como já mencionado acima, é importante de ser considerado. De todo o levantamento bibliográfico realizado, apenas a pesquisadora Santos (2018) traz a temática racial como pauta principal e, por isso, se debruça a analisar especificamente canais de youtubers mirins negras. Ela encontra que duas, das quatro youtubers de 7 a 11 anos pesquisadas, abordam temas em seus vídeos especificamente sobre empoderamento, diversidade, preconceito e outros assuntos que perpassam a temática racial. Apesar de apenas duas abordarem diretamente essas temáticas, 3 delas sofreram episódios de racismo anteriormente ou ao longo da pesquisa, mais especificamente direcionados a suas aparências físicas e/ou falta de poder aquisitivo. Esses ataques em geral foram protagonizados por outras (supostas) 
crianças que assistiam ao canal, verbalizados nos comentários por meios de xingamentos como "macaca", "cabelo feio", "pobre", entre outros. Após vivenciarem os episódios de racismo, duas das crianças fizeram vídeos demostrando descontentamento com a atitude dos seguidores, mas nenhuma delas passou a abordar a temática racial em seus vídeos. As outras duas crianças, uma tendo relatado caso de racismo e a outra não, abordaram a temática da negritude em seus canais, com falas sobre empoderamento para meninas negras e recorte racial na indicação de produtos para cabelos, por exemplo. Em relação às semelhanças e diferenças entre os canais de meninas negras e brancas, Santos encontrou que variam, de acordo com as vivências e desejos individuais de cada uma das crianças. Sobre isso, a autora conclui:

Ao mesmo tempo que as quatro meninas apresentam slimes, histórias, roteiros de viagem, ou ainda apresentam os seus quartos, tal qual faz a grande maioria das youtubers mirins, o fato de participarem dessa mídia digital, contribui para que outras meninas negras percebam que esse, também é um espaço a ser ocupado por elas (SANTOS, 2018, p. 199)

Renata Tomaz (2017) é uma pesquisadora da área de Comunicação que vem se dedicando nos últimos anos a estudar a plataforma do YouTube, tendo realizado em seu doutorado na UFRJ uma pesquisa ampla sobre a temática de youtubers mirins. Por também ter escolhido a área da Sociologia da Infância como principal referencial teórico, suas concepções e achados dialogam bastante com as visões de criança e infância defendidas neste trabalho. $O$ título de sua tese "O que você vai ser antes de crescer? Youtubers, Infância e Celebridade" já aponta para um lugar de protagonismo das crianças como atores sociais, que não mais precisam esperar crescerem para "serem alguém". A metodologia utilizada foi a etnografia, a partir do acompanhamento de 4 canais de famosas youtubers mirins, e da ida a "encontrinhos" que as mesmas organizavam, geralmente em shoppings da cidade - evento onde os seguidores podem conhecê-las. Indo de encontro com o que já foi apontado anteriormente, Tomaz também percebe o lúdico e a brincadeira como aspecto principal das produções infantis, entretanto, não apenas o simples brincar, mas o brincar associado à performance, uma vez que as crianças estão brincando para alguém no caso, para outras crianças. As youtubers dividem suas rotinas infantis e trazem para o público algo que antes era da esfera do privado, se apropriando do YouTube como uma plataforma que possibilita esse compartilhamento. Em relação a isso, Tomaz ressalta que: 
O fenômeno dos youtubers mirins não pode ser visto apenas como uma cooptação de crianças vulneráveis, narcisistas ou consumistas em um projeto puramente mercadológico. Em vez disso, precisa ser abordado dentro de uma dinâmica que comporta sensíveis alterações culturais na concepção da criança e da infância, bem como na formulação de determinados projetos subjetivos. Para além de geradores de conteúdo da plataforma de vídeos, os youtubers mirins se tornaram modelos do que ser e de como estar no mundo. Investigar sua emergência permitiu identificar novas ofertas de subjetividades infantis. (TOMAZ, 2017, p. 199)

Tomaz (2017), assim como López-Villafranca et al (2019), Jorge (2018), Girão (2018) e Marôpo (2018), aponta para o fato de as crianças, por mais que sejam as protagonistas dos canais, terem a presença forte de pelo menos um dos responsáveis, geralmente a mãe, por trás dos vídeos. Todas essas pesquisas citadas encontraram que, em alguns casos, os responsáveis participam diretamente dos vídeos junto com as crianças e, em outros, estão por trás das câmeras ou produções dos canais. Por mais que as pesquisas apontem que a maioria dos vídeos sejam gravados em cenários cotidianos, como os quartos das crianças (TOMAZ, 2017; MARÔPO; SAMPAIO; MIRANDA, 2018), e não apresentem elementos de edição tão avançados (MCROBERTS et al., 2016; GIRÃO, 2018), muitas vezes os responsáveis de youtubers mirins de sucesso trabalham exclusivamente com o gerenciamento do canal da criança (TOMAZ, 2017), fato que demonstra que não é tudo tão simples quanto parece.

Lange (2014), que realizou a primeira pesquisa etnográfica acompanhando crianças produtoras de vídeos no YouTube logo que a plataforma foi criada, aponta como a habilidade técnica para as produções de vídeos se diferencia mesmo entre crianças youtubers de uma mesma classe social. A autora aponta que as oportunidades de aprendizagem surgem a partir da mediação de pares, responsáveis e até mesmo entre os youtubers e seus espectadores (LANGE, 2014).

Por trás dos vídeos descontraídos e do compartilhamento de rotinas infantis, existe a questão do sucesso e da fama que essas crianças vivenciam, visível nos comentários deixados nos vídeos e nos eventos de "encontrinhos" (TOMAZ, 2017). Tomaz (2017) aponta, no entanto, que essa fama difere daquela de grandes ídolos clássicos da televisão, por exemplo. Os youtubers mirins tratam seus espectadores menos como "fãs" ou "seguidores" e mais como uma comunidade de amigos, em que suas opiniões e desejos são fundamentais de serem contemplados. E as crianças que assistem aos youtubers, ao mesmo tempo que em alguns casos se veem como semelhantes a eles, também almejam ter a fama e o sucesso que eles têm (TOMAZ, 
2017; MELO; GUIZZO, 2019), principalmente para que possam "ter mais amigos", expandindo, assim, suas comunidades de pares (TOMAZ, 2017).

Essa construção de uma comunidade de pares seguidores de um canal é realizada a partir de uma série de fatores, incluindo estratégias de engajamento que são bastante comuns nos canais de youtubers mirins (TOMÉ; BORGES, 2019). Tais estratégias consistem principalmente em pedir para que os espectadores interajam com o conteúdo a partir de falas como: "se inscrevam no canal", "deixem likes" e "comentem no vídeo" (TOMAZ, 2017). Outras estratégias familiares são: ter um bordão definido como frase de abertura dos vídeos (MCROBERTS et al., 2016; LEÃO; PRESSLER, 2017; MARÔPO; SAMPAIO; MIRANDA, 2018; BENN, 2019; TUR-VIÑES; NÚÑEZ-GÓMEZ; MARTÍNEZ-PASTOR, 2019) ou até mesmo um "nome" para aquela comunidade de amigos, como, por exemplo, "amigos e amigas" ou "bagunceiros e bagunceiras" (BENN, 2019).

Em contraposição com as pesquisas que foram apresentadas até agora, Dalethese (2017), inspirada em Freire (2016), buscou em sua dissertação de mestrado seguir e acompanhar o percurso de 7 crianças que produzem vídeos para o YouTube, mas que são "crianças comuns" e não youtubers mirins de sucesso. A pesquisadora constata que essas crianças veem o ato de postar vídeos como uma brincadeira, e não com o peso de uma tarefa obrigatória ou um trabalho, algo que se manifesta nas constantes mudanças de rumo dos canais, que mudam de nome, de temáticas, têm vídeos apagados ou até mesmo são deletados inteiramente. As crianças brincam de ser youtubers, dentro e fora das telas, brincam de filmar e filmam suas brincadeiras. Sobre isso, a autora conclui: "Os canais, os vídeos e as postagens das crianças duram o tempo de uma brincadeira. Há um momento de acabar e o prazer está no próprio ato de produzir, encenar, em ter um canal. E a brincadeira só tem graça enquanto ela dura" (DALETHESE, 2017, p. 154)

Apesar dessa efemeridade, Dalethese (2017) relata que as crianças expressam desejo por crescerem, ficarem conhecidas na plataforma e terem fama, não somente para serem vistas, mas para se sentirem pertencentes àquela comunidade. Os tipos de vídeos mais frequentes dos canais são semelhantes aos das youtubers de sucesso, que são vistos como ídolos e inspiração para as crianças que postam vídeos na plataforma. Outra semelhança são as falas de início e fim dos vídeos, pedindo engajamento por meio de likes e comentários - prática que acontece inclusive entre as crianças que dizem ser youtuber mesmo sem postarem vídeos na plataforma, 
reforçando a ideia de que é algo que permeia fortemente essa cultura, se realizado de forma quase automática (DALETHESE, 2017).

Como já foi ressaltado anteriormente, existe sim uma certa padronização nos formatos e tipos de vídeos de youtubers mirins, famosos ou não, mas, como aponta Tomaz (2017) e Dalethese (2017), cada uma das crianças constrói seu caminho de forma diferente e consegue imprimir no canal a sua identidade e especificidade, sem deixar o caráter lúdico de lado.

Após ter apontado os principais achados das pesquisas que têm como foco os youtubers mirins, iremos agora nos dedicar a apresentar os trabalhos que mais se aproximam e dialogam com nosso tema específico, focando naqueles que exploram aquilo a que as crianças estão assistindo no YouTube, e quais sentidos elas atribuem a esses conteúdos e ao uso do YouTube como um todo.

Como apontado em capítulos anteriores, por conta da restrição de idade que o YouTube apresenta para a criação de conta na plataforma, é difícil chegarmos a dados sobre os conteúdos a que as crianças estão assistindo. Além de não podermos contar com tais dados, são raras as pesquisas que realizam algum tipo de levantamento em larga escala para analisar quais são os tipos de vídeos e canais a que as crianças mais assistem. Apresentaremos a seguir algumas das pesquisas que realizam tais levantamentos, mesmo alguns não sendo com grandes quantidades de participantes. Após esta primeira apresentação, tentaremos agrupar os achados mais relevantes das pesquisas que se relacionam ao nosso projeto de pesquisa.

\subsection{3}

\section{As crianças e os conteúdos do YouTube}

Luciana Corrêa (2016) da ESPM Media Lab realizou um dos únicos levantamentos de canais assistidos por crianças no YouTube de larga escala, encontrando 230 canais na plataforma com conteúdos direcionados ou consumidos por crianças, 120 a mais do que havia encontrado em 2015. Dentre esses 230 canais, a pesquisadora aponta que 48 estão na lista dos 100 canais com maior audiência no YouTube Brasil. Corrêa (2016) optou por separar os canais encontrados em categorias diversificadas, sendo assim classificados por ela: 58 canais de games, 35 de programação de TV, desenhos e novelas infantis, 35 de desenhos e músicas infantis, 26 de 
propagandas de brinquedos, unboxing ${ }^{7}$ e vídeos de brincadeiras, 61 de youtubers mirins, 14 de youtubers teen e apenas 1 canal educativo. Apesar de não deixar claro no relatório disponível online a metodologia utilizada para se chegar a esses canais, o levantamento demonstra como os canais para crianças vêm aumentando e se tornando populares na plataforma.

Ribeiro (2020) realizou em seu mestrado uma pesquisa exploratória que visava conhecer as práticas de produção e consumo de vídeos de crianças de 7 a 12 anos, com foco nas percepções das próprias crianças. Ancorada fortemente nos estudos das culturas infantis, essa é a pesquisa que mais se assemelha à proposta do meu trabalho, justamente por considerar a participação das crianças como foco principal. A pesquisa foi realizada em duas etapas: primeiramente foi aplicado um questionário a 65 crianças de 2 escolas (uma pública e uma particular) de Salvador - BA e, posteriormente, foram selecionadas 8 dessas crianças para serem entrevistadas e também observadas em suas práticas no YouTube. A metodologia contou ainda com a presença de uma criança-investigadora que participou de toda as etapas da pesquisa, desde a construção do questionário até a análise dos dados.

No levantamento de Ribeiro, foram citados ao todo 108 canais pelas 65 crianças, sendo os canais mais citados: Felipe Neto (10), Gato Galáctico (6), Luccas Neto (5), Rezendeevil (5), Camila Loures (4), Julia Minegirl (4), Lipão Gamer (3), Authentic Games (3) e Crescendo com a Luluca (3). Essa tendência de as crianças elencarem uma diversidade grande de canais também foi percebida por Araújo (2019) e Aran-Ramspott, Fedele e Tarragó.

Em relação aos tipos de canais preferidos das crianças, Ribeiro (2020) optou por deixar que as próprias crianças criassem categorias para agrupar os canais elencados, sendo assim as categorias com maiores números de canais: jogos (25), youtubers adultos (25), canais de youtubers mirins (11), canais de desenhos/programas da TV (11) e canais de futebol (7). Houve uma diferença de gênero entre categorias preferidas, sendo "jogos", "futebol” e "curiosidades" mais citadas por meninos e "youtubers mirins", "desenhos/programas da TV” e "artesanato/ideias" por meninas. Não foram apresentados testes estatísticos para sabermos se tais diferenças são de fato significativas, mas em outros momentos da pesquisa as crianças explicitam

\footnotetext{
${ }^{7}$ Vídeos em que as crianças abrem embalagens de presentes ganhados, geralmente por empresas.
} 
essa separação entre canais que são de meninas e de meninos, atribuindo adjetivos pejorativos aos conteúdos destinados ao gênero oposto (RIBEIRO, 2020).

Em outra pesquisa exploratória, realizada por Araújo (2019) a partir de questionários semiestruturados com 30 crianças do $4^{\circ}$ ano de escolas públicas e particulares de João Pessoa - PB, foi encontrado que os canais preferidos das crianças contêm prioritariamente temas relacionados a trollagens 8 , "pegadinhas", desafios, compras e ao jogo Minecraft ${ }^{9}$. Quando perguntadas quais eram seus canais preferidos, as crianças citaram um total de 96 canais, gerando, novamente, uma lista extensa de preferência. Os primeiros lugares foram ocupados, na escola pública, por Felipe Neto, Luccas Neto e Planeta das Gêmeas, enquanto na escola particular o topo da lista foi composto por Julia Minegirl, Ibighit e Felipe Neto.

A pesquisa "A influência do YouTube no universo infantil" (BEZERRA, 2018) foi realizada a partir de entrevista semiestruturada com 30 crianças de 8 a 12 anos, selecionadas a partir da rede de contato da pesquisadora em Fortaleza - CE. O objetivo principal consistiu em investigar o comportamento das crianças no YouTube, identificando se há influência dos youtubers no universo das crianças, principalmente em relação à compra de produtos. Em relação aos tipos de vídeos preferidos das crianças, os achados apontam que os meninos se interessam mais por conteúdos relacionados a games ou vídeos engraçados e as meninas manifestaram preferência por vídeos que tratam da produção de slime.

É importante ressaltar que as três últimas pesquisas apresentadas foram realizadas em diferentes estados da região Nordeste, refletindo um possível investimento maior em pesquisas com essa temática nessa região do que em outras. Seria importante que os dados encontrados fossem contrastados com os resultados de outras regiões, para sabermos se tais tendências podem ser consideradas nacionais. Nossa hipótese é que a questão do caráter lúdico dos vídeos e da função principal de entretenimento é algo que tem mais a ver com as culturas infantis do que com a região geográfica, uma vez que até mesmo pesquisas internacionais (ARANRAMSPOTT; FEDELE; TARRAGÓ, 2018; RENÉS ARELLANO; GOZÁLVEZ PÉREZ; BERLANGA FERNÁNDEZ, 2020) apontam para essa tendência.

\footnotetext{
${ }^{8}$ Vídeos bastante famosos no YouTube atualmente, que basicamente apresentam uma pegadinha com alguém, podendo ser com outras crianças ou com adultos.

${ }^{9}$ Jogo eletrônico popular entre as crianças, no qual elas podem construir objetos e cenários com blocos e também se aventurar com seus personagens.
} 
As crianças assistem ao YouTube primordialmente para se divertirem, por acharem os vídeos e/ou youtubers legais e engraçados (MORAES, 2017; ARANRAMSPOTT; FEDELE; TARRAGÓ, 2018; SATLER; CARRIJO, 2019; RENÉS ARELLANO; GOZÁLVEZ PÉREZ; BERLANGA FERNÁNDEZ, 2020; RIBEIRO, 2020). Ribeiro (2020) argumenta que as crianças, principalmente as de escolas particulares, também relatam utilizar o YouTube para aprenderem e se informarem sobre coisas que não sabem, como por exemplo tirarem dúvidas de alguma matéria ou até mesmo aprenderem um penteado novo. Na pesquisa de Bezerra (2018) também são citados entre os usos do YouTube: obter informações sobre brinquedos, materiais escolares, games e novas estratégias dos jogos. Quando perguntadas sobre o que aprendem na plataforma, as meninas citam fazer slime e montar looks e os meninos 'jogar Minecraft' e serem engraçados, assim como são seus youtubers preferidos (BEZERRA, 2018).

Em relação aos youtubers preferidos das crianças, é frequente que elas os associem a alguém "comum", que é espontâneo e natural frente às câmeras (BEZERRA, 2018; SATLER; CARRIJO, 2019). Apesar de o grande foco das pesquisas acadêmicas ser sobre youtubers mirins, os achados indicam que as crianças dessa faixa etária entre 7-12 anos estão assistindo a vídeos principalmente de youtubers mais velhos que elas (ARAÚJO, 2019; RENÉS ARELLANO; GOZÁLVEZ PÉREZ; BERLANGA FERNÁNDEZ, 2020; RIBEIRO, 2020), sendo geralmente adolescentes ou adultos. Ribeiro (2020) também encontra que, em geral, as crianças preferem youtubers do mesmo gênero que elas, principalmente os meninos, que citaram apenas um canal protagonizado por uma mulher. Essa questão da identificação, ou não identificação, com os youtubers é um tema pouco explorado nas pesquisas, discutido apenas por Bezerra (2018). Sobre isso, a autora relata:

As crianças percebem várias semelhanças com os youtubers. Não vislumbram semelhanças físicas, mas acham a forma de falar, a forma de se vestir e outras características da personalidade, como ser bagunceiro, parecidos com elas. Percebem, também, que os youtubers jogam como elas. Também assinalaram que possuem idades semelhantes. As crianças se acham próximas aos youtubers, em razão de um grande número de vídeos tratar da vida cotidiana dos seus ídolos. (BEZERRA, 2018, p. 45)

Diferentemente da pesquisa sobre televisão apresentada anteriormente (DUARTE; LEITE; MIGLIORA, 2007), Bezerra (2018) aponta que as crianças não mostram ter ideia da lógica de mercado por trás do YouTube. Apesar de algumas saberem que os youtubers ganham muito dinheiro, elas não evidenciam 
conhecimento de que eles estão sendo pagos para mostrar os produtos e fazer propaganda; acreditam que estão fazendo por vontade própria e por realmente gostarem daquilo. Da mesma forma, mostram não entender com profundidade o quão trabalhoso é fazer os vídeos, pensam que os youtubers mirins são crianças "comuns" como eles, sem se darem conta da rotina de gravações e da responsabilidade que vem atrelada a ter um canal na plataforma (BEZERRA, 2018).

Um outro aspecto relevante de ser mencionado é que, apesar de algumas crianças considerarem o YouTube como uma rede social (SATLER; CARRIJO, 2019), não necessariamente elas utilizam todas as funções de interação da plataforma, como, por exemplo, os comentários nos vídeos. Ribeiro (2020) encontrou que, em geral, as crianças de escolas públicas e as meninas têm mais costume de comentar em vídeos. Os motivos relatados por elas para deixarem comentários nos vídeos foram: dar suas opiniões e/ou sugestões sobre os vídeos, responder solicitação dos youtubers e buscar interação com eles. Em contraste com a pesquisa de Ribeiro (2020) em que a maioria das crianças comentam os vídeos, Satler e Carrijo (2019) encontram nas crianças pesquisadas uma certa resistência em deixar comentários, optando por fazê-lo apenas quando há uma meta de interação a ser atingida pelo youtuber. O "não comentar" os vídeos pode ser fruto de não ter o conhecimento para tal (RIBEIRO, 2020), impedimentos tecnológicos (RIBEIRO, 2020) ou até mesmo o fato de o campo dos comentários ser repleto de críticas aos queridos youtubers (SATLER; CARRIJO, 2019).

Continuando nesse tópico do que as crianças dizem não gostar no YouTube, Ribeiro (2020) aponta que elas, em geral, apresentam desagrados em relação a: o funcionamento da plataforma, por conta de mudanças realizadas ou dificuldade para encontrar conteúdos; a exposição de propagandas que atrapalham a visualização dos vídeos e os riscos de exposição a conteúdos que incomodam, principalmente os vídeos assustadores. Na pesquisa de Aran-Ramspott, Fedele e Tarragó (2018), com crianças espanholas de 11 e 12 anos, os incômodos citados também perpassam as questões técnicas e de propagandas, incluindo o clickbait $^{10}$, e acrescentam a falta de etiqueta online e os comportamentos rudes de determinados youtubers. Outros

\footnotetext{
${ }^{10}$ Clickbait poderia ser traduzido para o português como "isca de clique", que é quando fazem uma chamada falsa ou exagerada visando que o espectador clique no conteúdo. Esse é um termo pejorativo, pois as pessoas em geral se sentem enganadas quando apertam em um vídeo, por exemplo, que não corresponde ao que foi prometido no título ou mostrado na capa.
} 
conteúdos assistidos pelas crianças e considerados inadequados pelos pesquisadores são: os palavrões e linguagens impróprias (MORAES, 2017; RENÉS ARELLANO; GOZÁLVEZ PÉREZ; BERLANGA FERNÁNDEZ, 2020); os vídeos de trollagens perigosas (ARAÚJO, 2019) e os reforços de estereótipos e discriminações (LUZ, 2018).

Para encerrar esta seção, algumas pesquisas também perguntam às crianças espectadoras se elas têm vontade de ser youtubers. Bezerra (2018) encontrou que todos os 30 entrevistados desejam ter o próprio canal no YouTube, e três deles até mesmo se consideram youtubers, por gravarem vídeos de rotina no próprio celular. Eles relatam que estão apenas esperando ter a autorização dos pais para poderem criar um canal e divulgar os vídeos. É importante ressaltar, no entanto, que, na pesquisa de Bezerra, os entrevistados faziam parte de um mesmo grupo social e que muitos conviviam juntos, o que pode significar um compartilhamento de desejos e vontades mais parecidos.

Já na pesquisa de Ribeiro (2020), 43 das 65 crianças pesquisadas apresentaram o desejo de postar vídeos na plataforma. As crianças que disseram não terem vontade de postar vídeos alegaram timidez, "falta de jeito", falta de habilidade técnica ou impedimento por parte dos responsáveis. Dessas 65 crianças, 29 responderam já terem postado algum vídeo na plataforma, mas, quando indagadas sobre isso, algumas apresentaram dificuldade em saber se haviam postado mesmo ou em qual canal havia sido, apontando novamente para uma fluidez e percepção do "ser youtuber" como uma brincadeira, e não como um trabalho (RIBEIRO, 2020).

Após ter realizado esse levantamento e diante das lacunas encontradas, optamos por desenhar a metodologia a partir de duas etapas, sendo a primeira um levantamento quantitativo dos tipos de vídeos e canais preferidos das crianças e a segunda entrevistas semiestruturadas com 30 crianças de 8 a 10 anos de diferentes faixas de renda familiares. Como vimos, é preciso investir em mais pesquisas quantitativas para mapearmos o consumo de vídeos das crianças, assim como privilegiar as metodologias que contemplem as vozes das mesmas, visando um entendimento mais profundo de suas práticas na plataforma do YouTube. Na próxima seção, explicaremos o caminho metodológico de forma mais detalhada. 


\section{O caminho da pesquisa}

Este capítulo vai explicar e detalhar quais foram as fases da pesquisa, os procedimentos metodológicos utilizados e as análises de dados realizadas para responder à seguinte pergunta de pesquisa: “A quais conteúdos as crianças estão assistindo no YouTube e como esses conteúdos nos permitem pensarmos as infâncias atuais?”

\section{1}

\section{Delineamento metodológico}

Com base na pergunta de pesquisa a que se desejava responder e nos objetivos traçados, optamos por utilizar métodos mistos, que se caracterizam pela combinação de técnicas quantitativas e qualitativas em um mesmo estudo. Creswell (2010) define essa estratégia metodológica da seguinte forma:

Essa técnica emprega estratégias de investigação que envolvem coleta de dados simultânea ou seqüencial para melhor entender os problemas de pesquisa. A coleta de dados também envolve a obtenção tanto de informações numéricas (por exemplo, em instrumentos) como de informações de texto (por exemplo, em entrevistas), de forma que o banco de dados final represente tanto informações quantitativas como qualitativas. (CRESWELL, 2010, p. 35)

Por se tratar de uma temática com pouca produção acadêmica, como foi visto no capítulo anterior, os métodos mistos foram relevantes para dar robustez aos achados desta pesquisa, que pode ser organizada em duas etapas distintas, mas complementares. Gatti (2004) aponta que a combinação de métodos quantitativos e qualitativos em uma mesma pesquisa pode enriquecer a compreensão dos objetos investigados, desde que haja reflexão teórica do pesquisador para dar sentido ao material analisado.

A primeira fase se constitui a partir de um levantamento quantitativo que visou elencar a quais canais e tipos de vídeos as crianças de 8 a 10 anos residentes no município do Rio de Janeiro estavam assistindo no YouTube. Os métodos quantitativos, quando claros em seus alcances e alinhados com uma boa base teórica, 
podem ser muito úteis para a compreensão de diversos aspectos educacionais (GATTI, 2004). Como ressalta a autora, é importante, entretanto, saber que resultados quantitativos, depois de uma boa análise, fornecem indícios, semelhanças e proximidades, não certeza e verdades absolutas.

Já a segunda etapa da pesquisa teve como metodologia entrevistas individuais e coletivas com crianças da mesma faixa etária - 8 a 10 anos -, nas quais buscamos entender mais a fundo quais sentidos as mesmas atribuíam aos conteúdos assistidos, e quais eram os motivos para suas preferências de vídeos e de canais. Segundo Duarte (2004), as entrevistas são uma boa escolha metodológica quando se visa mapear práticas, crenças e valores de universos sociais específicos, possibilitando um mergulho profundo nas formas como aquele grupo constrói suas lógicas, percepções e significados. Vistas muitas vezes como algo subjetivo e pouco confiável, a autora defende que entrevistas precisam ser realizadas com o mesmo rigor metodológico que outros tipos de coleta, e dependem de bastante preparo teórico e competência técnica por parte do pesquisador.

Tendo em mente as possibilidades e limites de cada tipo de escolha metodológica, a combinação de métodos quantitativo e qualitativo possibilitou uma visão mais completa acerca de um fenômeno relativamente novo e inexplorado. É essencial ressaltar desde já que a coleta de dados se deu no ano de 2020, ano em que o mundo inteiro foi acometido pela pandemia do Sars-CoV-2 (ou COVID-19), que, em janeiro de 2021 já tinha acumulado mais de 2.000.000 de mortes. Por esse motivo, diversas adaptações tiveram que ser realizadas, principalmente em relação ao método de produção de dados. Na seção a seguir, explicarei em detalhes como ocorreu cada uma das duas etapas da pesquisa.

\section{2}

\section{Etapa I - Levantamento das preferências das crianças}

O objetivo desta etapa foi mapear quais os canais e tipos de vídeos preferidos pelas crianças de 8 a 10 anos de idade residentes no município do Rio de Janeiro, considerando possíveis diferenças de gênero, idade e perfil da escola que frequentam. Para isso, foi realizado um levantamento inicial (Apêndice 1) contendo, além da identificação de idade e gênero da criança, duas perguntas. Na primeira, a 
participante precisava assinalar, dentre as 25 opções de tipos de vídeos, todos que representavam seus favoritos. Havia também o espaço "outros", onde elas podiam preencher com um tipo de vídeo que não estava na lista ${ }^{11}$. Já na segunda pergunta, a criança precisava elencar seus 3 canais preferidos do YouTube, podendo colocar apenas um ou dois, se desejasse. Antes do momento de produção de dados, foi realizado um teste piloto na turma de $3^{\circ}$ ano regida por uma das integrantes do nosso grupo de pesquisa, para verificar se as questões e opções estavam claras para as crianças. Foram realizadas algumas modificações em relação à ordem das perguntas e também em relação às opções na pergunta sobre gênero.

É importante explicar que a variável gênero, que será discutida mais à frente, foi um ponto controverso na pesquisa. Nossa primeira ideia era deixar, além das opções "menino" e "menina", uma terceira opção que permitisse a criança escolher “outros/prefiro não dizer". Porém, no teste piloto do levantamento, a turma demonstrou bastante agitação por conta dessa terceira opção, fazendo piadas sobre e/ou não entendendo muito bem o que deveriam marcar. A professora que aplicou o levantamento disse que teve dificuldade em lidar com essa questão e fazer com que as crianças focassem no resto do questionário. Então, após conversas com pessoas que trabalham em escolas com crianças dessa faixa etária, incluindo diretores, nossa decisão foi retirar essa terceira opção no levantamento presencial e deixar a criança livre para assinalar "menino", "menina" ou deixar em branco. Já no levantamento online - que será apresentado em breve-, essa terceira opção foi acrescentada.

\section{2 .1}

\section{Produção de Dados}

A produção de dados da Etapa I foi a parte mais afetada pela pandemia. O planejamento inicial era que essa produção de dados seria realizada com crianças de escolas públicas e particulares do município do Rio de Janeiro durante o $1^{\circ}$ semestre de 2020. No início de março de 2020, foi solicitada a aprovação da SME para a realização da pesquisa nas escolas públicas. Enquanto isso, a produção de

\footnotetext{
${ }^{11}$ A lista foi construída pela autora a partir de uma análise flutuante do YouTube e de busca em sites que falam sobre a plataforma.
} 
dados se iniciou na primeira das escolas particulares selecionadas, localizada em um bairro de classe média baixa a baixa. Logo em seguida, no dia 17 de março, as escolas foram fechadas e teve início uma quarentena. Apenas em junho conseguimos o retorno da SME (ver Anexo 1), informando que seria necessário esperar que as escolas voltassem a abrir para a realização da pesquisa. Nesse momento, já havíamos optado por adaptar a metodologia a um novo formato. Então, os primeiros dados foram os únicos produzidos em escola, sendo os procedimentos posteriores adaptados ao formato online. Apresentarei a seguir cada um dos campos e procedimentos metodológicos de produção de dados.

\subsubsection{1}

\section{Pré-Pandemia}

O primeiro campo de produção foi uma escola particular de carácter filantrópico localizada em uma comunidade na Zona Sul do Rio de Janeiro. Segundo o diretor da escola, a grande maioria dos alunos possuem bolsa de $100 \%$ para estudarem lá e, os outros pagam apenas um valor simbólico. Assim, apesar de ser uma escola particular, os alunos atendidos possuem condições socioeconômicas menos favorecidas, sendo a maioria moradores da comunidade onde a escola se localiza.

Após diversas reuniões com a direção e coordenação da escola, que foram bastante acolhedoras, a produção de dados se deu durante duas idas à escola no começo do mês de março de 2020. A produção de dados foi toda realizada por mim. Tive a autorização para entrar em todas as turmas de $3^{\circ}, 4^{\circ}$ e $5^{\circ}$ anos do Ensino Fundamental I, sendo esses os anos que melhor correspondiam à faixa etária desejada para a pesquisa. No total, foram 252 crianças que participaram desse levantamento inicial. Na tabela a seguir, podemos ver a distribuição das crianças por ano/turma:

Tabela 1 - Distribuição de crianças por turma

\begin{tabular}{|c|c|c|c|}
\hline Anos & Turmas & Crianças & Total \\
\hline \multirow{3}{*}{30 ano } & Turma 1 & 17 & \multirow{2}{*}{ 82 } \\
\cline { 2 - 3 } & Turma 2 & 17 & \\
\cline { 2 - 3 } & Turma 3 & 24 & \\
\cline { 2 - 3 } & Turma 4 & 24 & \\
\hline
\end{tabular}




\begin{tabular}{|c|c|c|c|}
\hline \multirow{3}{*}{$4^{\circ}$ ano } & Turma 1 & 29 & \multirow{3}{*}{86} \\
\hline & Turma 2 & 30 & \\
\hline & Turma 3 & 27 & \\
\hline \multirow{3}{*}{$5^{\circ}$ ano } & Turma 1 & 27 & \multirow{3}{*}{84} \\
\hline & Turma 2 & 29 & \\
\hline & Turma 3 & 28 & \\
\hline \multicolumn{3}{|c|}{ Total de crianças } & 252 \\
\hline
\end{tabular}

Fonte: elaborado pela autora

Mediante autorização da coordenação e das professoras, eu entrei em cada uma das turmas e explicava para as crianças o meu trabalho como mestranda e o meu objetivo enquanto pesquisadora. Li em voz alta cada uma das questões do levantamento (Apêndice 1), explicando o procedimento e deixando claro que a participação de cada um era voluntária e que, se precisassem de ajuda, poderiam me chamar. É válido ressaltar que todas as crianças desejaram participar da pesquisa e a maioria demonstrou bastante animação de poder falar sobre um tema tão caro e familiar. Eu e as professoras das turmas auxiliamos algumas crianças que estavam com dificuldade de entender alguma pergunta ou de escrever o nome de seus canais preferidos. Ao me despedir de cada turma, muitas desejaram que eu tirasse uma boa nota em meu trabalho e perguntaram se eu iria novamente à escola fazer outra atividade com elas. $\mathrm{O}$ intuito era de voltar para realizar entrevistas com algumas das crianças, mas, como já dito, os planos tiveram que mudar.

\subsubsection{2}

\section{Os planos mudaram}

Depois de alguns meses na incerteza sobre quanto tempo duraria a quarentena e se daria ou não para continuar o procedimento nas escolas presencialmente, percebemos que a situação infelizmente iria se prolongar mais do que o imaginado. Diante disso, decidimos construir o mesmo levantamento, agora no formato online. Como já havia um bom quantitativo de crianças da escola de perfil de nível socioeconômico (NSE) mais baixo que responderam ao questionário, o foco seriam as escolas que atendessem crianças de NSE mais elevado. Pela impossibilidade de contar com as escolas para distribuírem tais levantamentos, uma vez que estavam 
tendo que se readaptar para o ensino online do dia para a noite, a solução foi disparar o levantamento nas redes sociais (WhatsApp, Facebook e Instagram).

O protocolo foi transposto para o Google Forms, sendo que a única diferença foi ter acrescentado 2 perguntas: sobre a escola em que a criança estudava e em qual ano escolar ela se encontrava. O levantamento foi disparado primeiramente dentro do meu perfil pessoal do Facebook e Instagram e para os contatos do meu WhatsApp. O pedido feito era para que meus "amigos" compartilhassem o formulário com famílias que tinham crianças matriculadas no $3^{\circ}, 4^{\circ}$ ou $5^{\circ}$ ano de escolas particulares de renda alta no município do Rio de Janeiro (Apêndice 2). O questionário podia ser preenchido pela própria criança e/ou com a ajuda de algum responsável.

Conforme explicaremos na Etapa II, os primeiros formulários disparados contavam com duas partes, sendo a primeira composta por esse levantamento anônimo e a segunda com um convite para participar de uma entrevista. Os responsáveis por crianças que demostraram interesse em participar assinalavam autorizando a participação e colocavam seu número de telefone ou email de contato. Desses primeiros formulários obtivemos um total de 112 respondentes. Após essa primeira distribuição, disparei o formulário novamente em minhas redes, visando alcançar ainda mais pessoas, mas, dessa vez sem o convite para a entrevista, pois o quantitativo de crianças que se interessaram em participar da entrevista já havia sido atingido. Dessa segunda vez, consegui mais 47 respostas, totalizando 159 crianças participantes.

\section{2 .2}

\section{Perfil das crianças participantes}

O processo de tabulação dos levantamentos presenciais para chegar às crianças que de fato participariam da pesquisa durou cerca de um mês. Após passar todos os dados dos levantamentos físicos para uma planilha no Excel e separar os que não entrariam na análise por causa da idade das crianças (algumas não corresponderam à faixa etária desejada), eliminei 16 dos 252 levantamentos, ficando com o total de 236 respostas válidas.

Com os dados do Google Forms, o trabalho de organização foi mais simples, mas precisei também fazer essa separação por idade e por escola. Como a pesquisa foi divulgada em redes sociais, algumas pessoas que preencheram tinham crianças 
matriculadas em escolas diferentes do perfil socioeconômico desejado. Para realizar essa seleção de escolas, foi preciso pesquisar cada uma e ter uma ideia do público que a frequenta. Isso foi feito por meio de diálogo com pessoas conhecidas que trabalhavam em escolas e também por meio de visita aos sites das mesmas. Eliminei também as escolas municipais e federais que apareceram, deixando apenas as particulares. Assim, das 159 respostas obtidas, 40 foram eliminadas por não atenderem ao perfil econômico desejado e 11 por não atenderem aos anos escolares e faixa etária escolhida, restando 108 levantamentos.

No total, somando os levantamentos da escola que atende NSE menos favorecidos com os das escolas que atendem NSE mais elevados, foram 344 crianças que participaram desta primeira etapa da pesquisa. Para facilitar, chamarei esses perfis socioeconômicos das escolas de Grupo 1 e Grupo 2, respectivamente.

Após tabular e organizar os dados, foi possível traçar o perfil das crianças participantes deste estudo. A Tabela 2 a seguir mostra a distribuição das 344 crianças por grupo de escola, gênero e idade.

Tabela 2 - Perfil das crianças participantes

\begin{tabular}{|c|c|c|c|c|c|c|}
\hline \multirow{2}{*}{$\begin{array}{l}\text { Escolas / } \\
\text { Idade }\end{array}$} & \multicolumn{3}{|c|}{ Grupo 1 (NSE menos favorecido) } & \multicolumn{3}{|c|}{ Grupo 2 (NSE mais favorecido) } \\
\hline & Meninos & Meninas & $\begin{array}{c}\text { Não decla- } \\
\text { rado }\end{array}$ & Meninos & Meninas & $\begin{array}{c}\text { Não decla- } \\
\text { rado }\end{array}$ \\
\hline 8 anos & 39 & 31 & 4 & 16 & 14 & 0 \\
\hline 9 anos & 43 & 36 & 1 & 13 & 20 & 0 \\
\hline 10 anos & 44 & 38 & 0 & 24 & 20 & 1 \\
\hline \multirow{2}{*}{ Total } & 126 & 105 & 5 & 53 & 54 & 1 \\
\hline & \multicolumn{3}{|c|}{236} & \multicolumn{3}{|c|}{108} \\
\hline
\end{tabular}

Fonte: elaborado pela autora

Ressaltamos novamente que o gênero foi um ponto controverso na elaboração do levantamento. O Grupo 1, que respondeu o levantamento presencialmente, poderia assinalar o gênero como "menino", como "menina" ou deixar a opção em branco. Já o Grupo 2, que respondeu online, tinha ainda a opção de assinalar "outros/prefiro não dizer". Assim, não temos como saber se as 5 crianças que não assinalaram o gênero nos levantamentos presenciais sem querer pularam essa opção ou se realmente não quiseram responder. Não houve nenhum comentário a respeito disso durante o processo. 
Nos gráficos a seguir, detalhamos a distribuição das crianças participantes por perfil da escola (considerando o Grupo 1 a escola que atende crianças com NSE mais baixos e Grupo 2 as escolas que atendem crianças com NSE mais elevado), gênero e idade.

Gráfico 2 - Perfil das escolas das crianças participantes

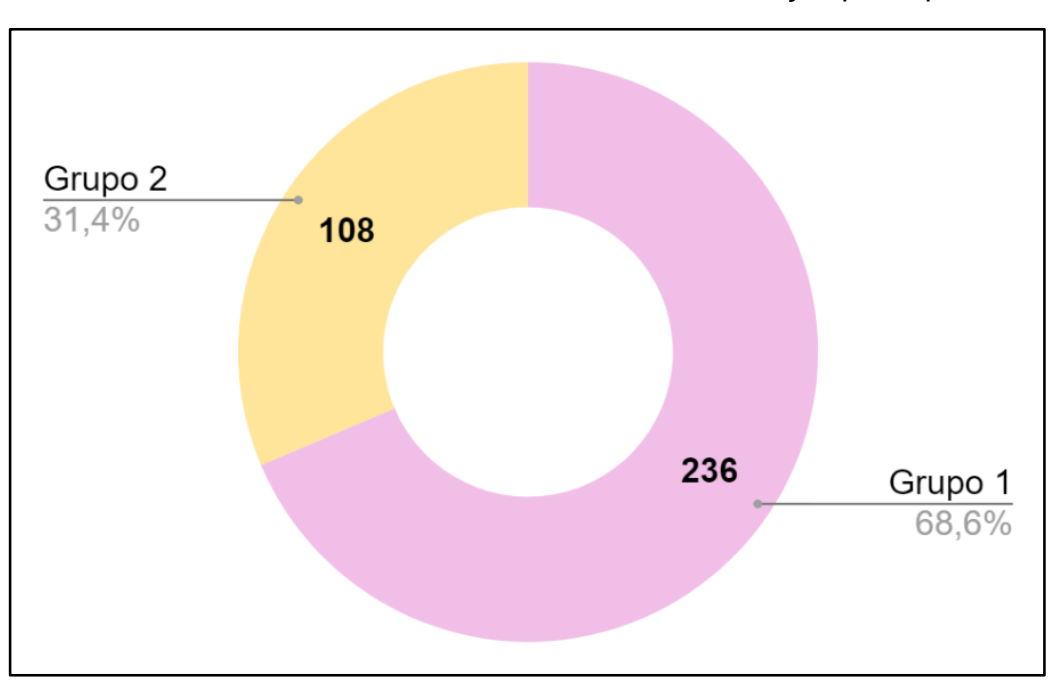

Fonte: elaborado pela autora

Gráfico 3 - Gênero das crianças participantes

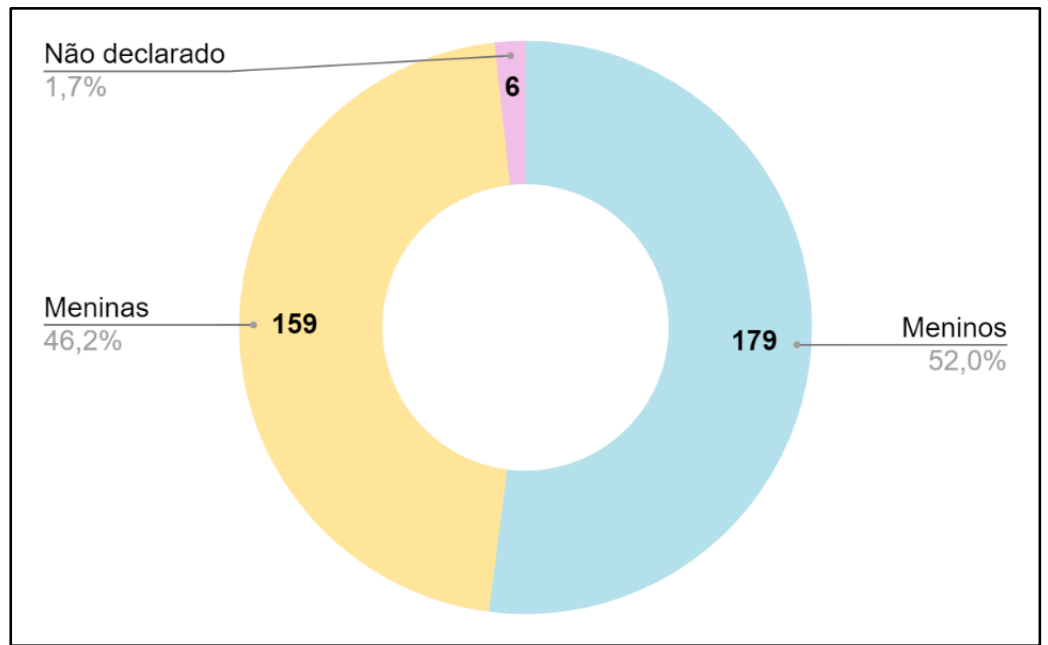

Fonte: elaborado pela autora 


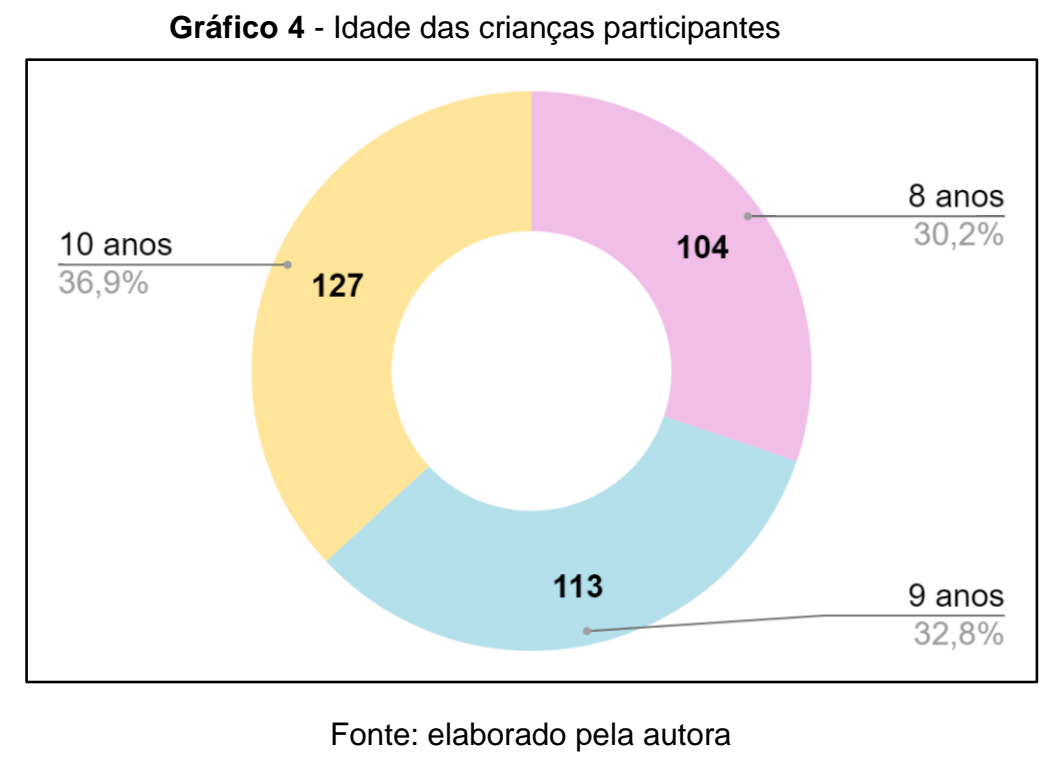

Os gráficos mostram que a distribuição entre idade e gênero das crianças participantes está bastante equilibrada. Entretanto, por causa da diferença metodológica, o quantitativo de crianças de escolas do Grupo 1 (NSE mais baixo) foi bem maior do que das escolas do Grupo 2 (NSE mais alto). Isso não será um problema, visto que a análise será feita em números percentuais, porém, é importante considerar a mudança de instrumento de produção de dados enfrentada quando isolamos a variável de perfil da escola. Essa discussão será retomada na apresentação dos resultados.

\section{2 .3}

\section{Análise de Dados}

A primeira parte da análise de dados consistiu na organização e padronização dos dados em tabelas do Excel. Precisei investigar os canais que as crianças apontaram como favoritos nos levantamentos, verificando se eles existiam na plataforma e padronizando a grafia dos nomes dos canais. Contabilizei e agrupei também os outros tipos de vídeos que as crianças mencionaram na pergunta aberta.

Após essa organização, foi utilizado primeiramente o Excel para a análise descritiva das variáveis de gênero, idade e perfil da escola, tanto em relação à pergunta sobre tipos de vídeo quanto à pergunta dos canais preferidos. Foi possível construir tabelas e gráficos de frequência da distribuição dos resultados. 
Posteriormente, foi realizado o teste de Qui-Quadrado usando o software SPSS 20.0 para verificar se as variáveis de gênero e idade tinham associações com os conteúdos a que as crianças assistem no YouTube.

\section{3}

\section{Etapa II - Entrevistas}

A segunda etapa da pesquisa visava conhecer mais a fundo as preferências das crianças no YouTube, os motivos de elas gostarem de certos tipos de vídeo e canais, e não de outros, e os usos e sentidos que elas atribuem à plataforma. Para isso, foi construído um roteiro de entrevista semiestruturada (ver Apêndice 3) que contemplou perguntas sobre o uso do YouTube em geral, sobre os tipos de vídeos e canais preferidos, incluindo aspectos relacionados à mediação parental e à cultura de pares, e, ao final, algumas perguntas sobre youtubers mirins.

Essa análise mais profunda a partir das falas das próprias crianças nos permitiu entender quais são as aproximações e afastamentos entre suas preferências no YouTube e as culturas infantis.

\section{3 .1}

\section{Participantes}

O convite para a participação da entrevista foi realizado de duas maneiras diferentes. Como não seria possível entrevistar as mesmas crianças da escola que responderam ao primeiro levantamento, visto que o retorno à escola não foi possível, precisei encontrar outras crianças que desejassem participar. Primeiramente, pedi para os integrantes do grupo de pesquisa, familiares e amigos divulgarem o convite (Apêndice 4) via WhatsApp para famílias de nível socioeconômico médiobaixo e/ou baixo, que tinham crianças na faixa etária de 8 a 10 anos.

Já o convite para as crianças de nível socioeconômico médio-alto ou alto foi realizado via formulário do Google Forms, ao final do levantamento. Esse processo será melhor detalhado na seção seguinte.

No total, foram 30 crianças que participaram das entrevistas, 8 crianças de 8 anos, 15 crianças de 9 anos e 7 de 10 anos. Em relação ao gênero, foram 13 meninos 
e 17 meninas. Elas foram distribuídas entre 17 entrevistas, sendo 6 individuais, 9 em dupla e 2 em trio, conforme o Quadro 5 a seguir.

Quadro 5 - Crianças participantes da entrevista

\begin{tabular}{|c|c|c|c|}
\hline Entrevista & Nome & Gênero & Idade \\
\hline \multirow{3}{*}{1} & Gabrielle & Menina & 8 anos \\
\hline & Gabo & Menino & 8 anos \\
\hline & Sophia & Menina & 10 anos \\
\hline 2 & Luana & Menina & 9 anos \\
\hline 3 & Supergamer & Menino & 9 anos \\
\hline \multirow{2}{*}{4} & Luiza & Menina & 9 anos \\
\hline & Camila & Menina & 8 anos \\
\hline \multirow{2}{*}{5} & Isadora & Menina & 10 anos \\
\hline & Daniel & Menino & 8 anos \\
\hline 6 & Dezembro & Menino & 9 anos \\
\hline \multirow{2}{*}{7} & Lulu & Menina & 8 anos \\
\hline & Ronaldo & Menino & 10 anos \\
\hline \multirow{3}{*}{8} & Sabrina & Menina & 9 anos \\
\hline & Anne & Menina & 9 anos \\
\hline & Miguel & Menino & 8 anos \\
\hline \multirow{2}{*}{9} & Bela & Menina & 9 anos \\
\hline & Kaique & Menino & 8 anos \\
\hline \multirow{2}{*}{10} & João & Menino & 9 anos \\
\hline & Davi & Menino & 9 anos \\
\hline \multirow{2}{*}{11} & Geremias & Menino & 9 anos \\
\hline & Nina & Menina & 8 anos \\
\hline \multirow{2}{*}{12} & Bruno & Menino & 9 anos \\
\hline & Micaele & Menina & 9 anos \\
\hline \multirow{2}{*}{13} & Games BR & Menino & 10 anos \\
\hline & Isabela & Menina & 9 anos \\
\hline 14 & Vitória & Menina & 9 anos \\
\hline 15 & Júlia & Menina & 10 anos \\
\hline 16 & Diego & Menino & 10 anos \\
\hline \multirow{2}{*}{17} & Amanda & Menina & 9 anos \\
\hline & $\mathrm{Li}$ & Menina & 10 anos \\
\hline
\end{tabular}


O perfil econômico das crianças participantes foi determinado com base na renda familiar declarada pelos responsáveis. As cinco opções de faixas salariais declaradas foram agrupadas em 3 grandes grupos, conforme mostra o Quadro 6.

Quadro 6 - Distribuição de renda das crianças participantes das entrevistas

\begin{tabular}{|c|c|c|}
\hline Renda Familiar & Faixa Salarial & Crianças \\
\cline { 1 - 1 } até 1 salário mínimo & \multirow{2}{*}{ faixa 1} & 14 \\
\cline { 1 - 1 } de 1 a 3 salários mínimos & & 4 \\
\cline { 1 - 1 } de 3 a 6 salários mínimos & faixa 2 & 12 \\
\cline { 1 - 1 } de 6 a 9 salários mínimos & \multirow{2}{*}{ faixa 3 } & \\
\cline { 1 - 2 } mais de 10 salários mínimos & & \\
\hline
\end{tabular}

Fonte: elaborado pela autora

\subsection{2}

\section{Produção de Dados}

Diante do cenário de Pandemia, as entrevistas, anteriormente planejadas para acontecerem nas escolas, precisaram ser realizadas virtualmente. A princípio, houve uma insegurança sobre se esse formato permitiria a profundidade e proximidade desejada com as crianças, mas, conforme será relatado aqui, tudo correu de forma bastante fluida e favorável.

Ao final das perguntas anônimas do levantamento, sobre tipos de vídeos e canais preferidos, eu acrescentei uma questão que perguntava se a criança desejava conversar mais comigo sobre aquele assunto. Caso ela selecionasse "não", o questionário era encerrado e enviado anonimamente. Caso ela selecionasse "sim", eu pedia então para ela chamar um responsável para que ele pudesse autorizar sua participação e deixar um meio de contato.

As crianças de cada faixa salarial foram entrevistadas com pares da mesma faixa. Na seção dos resultados e discussões, irei chamar a "faixa 1" de renda baixa, "faixa 2" de renda média e "faixa 3" de renda alta, apenas para simplificar a nomenclatura. 
Em ambas as formas de convite - diretamente por contato de pessoas conhecidas ou por preenchimento do levantamento -, após ter o WhatsApp ou email das famílias, eu entrava em contato com elas para enviar um novo formulário do Google Forms (ver Apêndice 5), dessa vez com o Termo de Consentimento Livre e Esclarecido (ver Apêndice 6) anexado, para que pudessem consentir com a participação das crianças. Além do termo, também tinha no formulário perguntas referentes à idade, gênero, nome da criança e faixa de renda mensal da família. Após o envio do formulário, eu explicava via WhatsApp ou email como a entrevista funcionaria e perguntava em quais horários a criança estava disponível.

A fim de deixar as famílias e crianças confortáveis, eu perguntava se existia alguma preferência entre realizar a entrevista coletivamente com outras crianças ou individualmente; se preferiam a chamada de vídeo no WhatsApp ou via Zoom; e se era melhor pelo celular da própria criança ou o do responsável. Também deixava claro que o responsável poderia ou não estar presente no momento da entrevista. Após coletadas essas informações, as crianças que concordaram em participar da entrevista coletiva foram agrupadas em duplas ou trios de acordo com sua disponibilidade de horário e renda familiar declarada.

As entrevistas duraram de 30 minutos a $1 \mathrm{~h}$ e 18 minutos, variando bastante em seu tempo de duração por conta das diferentes modalidades (individual, em dupla ou em trio). Todas as crianças e /ou responsáveis optaram por realizar a entrevista via chamada de vídeo no WhatsApp.

Ao iniciar a entrevista, primeiramente eu apresentava as crianças umas às outras, no caso de entrevistas coletivas. Destaco aqui que os participantes da entrevista número 9 eram primos, que quiseram fazer juntos, e da entrevista número 11 eram colegas da mesma sala da escola. Após me apresentar e explicar como a entrevista funcionaria, eu pedia o assentimento (Apêndice 7) das crianças para sua participação e para gravar a tela, dizendo que o anonimato seria preservado, que as gravações eram apenas para facilitar minha análise e que ninguém mais teria acesso a elas. Para a gravação das entrevistas, utilizei uma câmera externa posicionada para captar a imagem e o áudio, uma vez que o aplicativo do WhatsApp não permite a gravação de chamadas.

As primeiras perguntas da entrevista, conforme mostra o roteiro em Apêndice 3, eram referentes ao uso geral do YouTube. Nesse momento, as crianças podiam ainda estar tímidas e respondiam de forma mais curta e direta. Entretanto, nos 
blocos seguintes, que se referiam aos conteúdos e canais a que elas assistiam, a conversa ficou bem mais fluida comigo e com as outras crianças participantes. Como a entrevista era semiestruturada, tópicos novos surgiram ao longo das conversas e os tópicos previamente planejados foram mais ou menos explorados, de acordo com o fluxo da entrevista e o interesse das crianças.

Em geral, as crianças pareciam confortáveis e empolgadas em ter um espaço para falar de um tema que parecia ser interessante para elas. Apenas uma das 30 crianças demonstrou cansaço ao longo da entrevista, perguntando se ainda faltava muito para o final e expressando seu desejo de ir assistir aos seus vídeos no YouTube. Nesse caso, disse que não teria problema se ela quisesse interromper a entrevista, mas ela decidiu ficar até o final, acompanhando, assim, o colega participante.

Em relação aos responsáveis, 20 estiveram presentes no mesmo ambiente em algum momento da entrevista, mas apenas 8 ficaram sentados ao lado da criança, prestando atenção e interferindo de forma direta, seja explicando uma questão para ela ou até mesmo respondendo em seu lugar. Algumas crianças tinham suas casas bastante movimentadas por familiares, avós, irmãos, tios, primos, que passavam pelo cômodo em que a criança estava e algumas vezes até eram apresentados a mim. Isso não pareceu incomodar às crianças - pelo contrário, elas pareciam ficar mais à vontade com a presença de pessoas conhecidas.

Ao final da entrevista, eu agradecia a participação das crianças, explicava novamente no que consistia a preservação do anonimato delas, e solicitava que cada uma escolhesse um outro nome para que eu pudesse usar quando fosse "escrever meu trabalho". Apenas 3 crianças não quiseram escolher seus próprios nomes, então eu mesma escolhi posteriormente. Algumas crianças expressaram desejo de que seus nomes fossem os mesmos dos youtubers favoritos, mas eu expliquei que isso confundiria o texto na hora da escrita, então chegamos a um outro acordo ou fizemos uma adaptação. Exemplo: ao invés de usar o nome de Luluca, apelido de uma youtuber, a criança aceitou usar o nome de Lulu.

O Quadro 7, a seguir, detalha as características dos participantes e os procedimentos utilizados com eles. 
Quadro 7- Perfil das crianças participantes das entrevistas

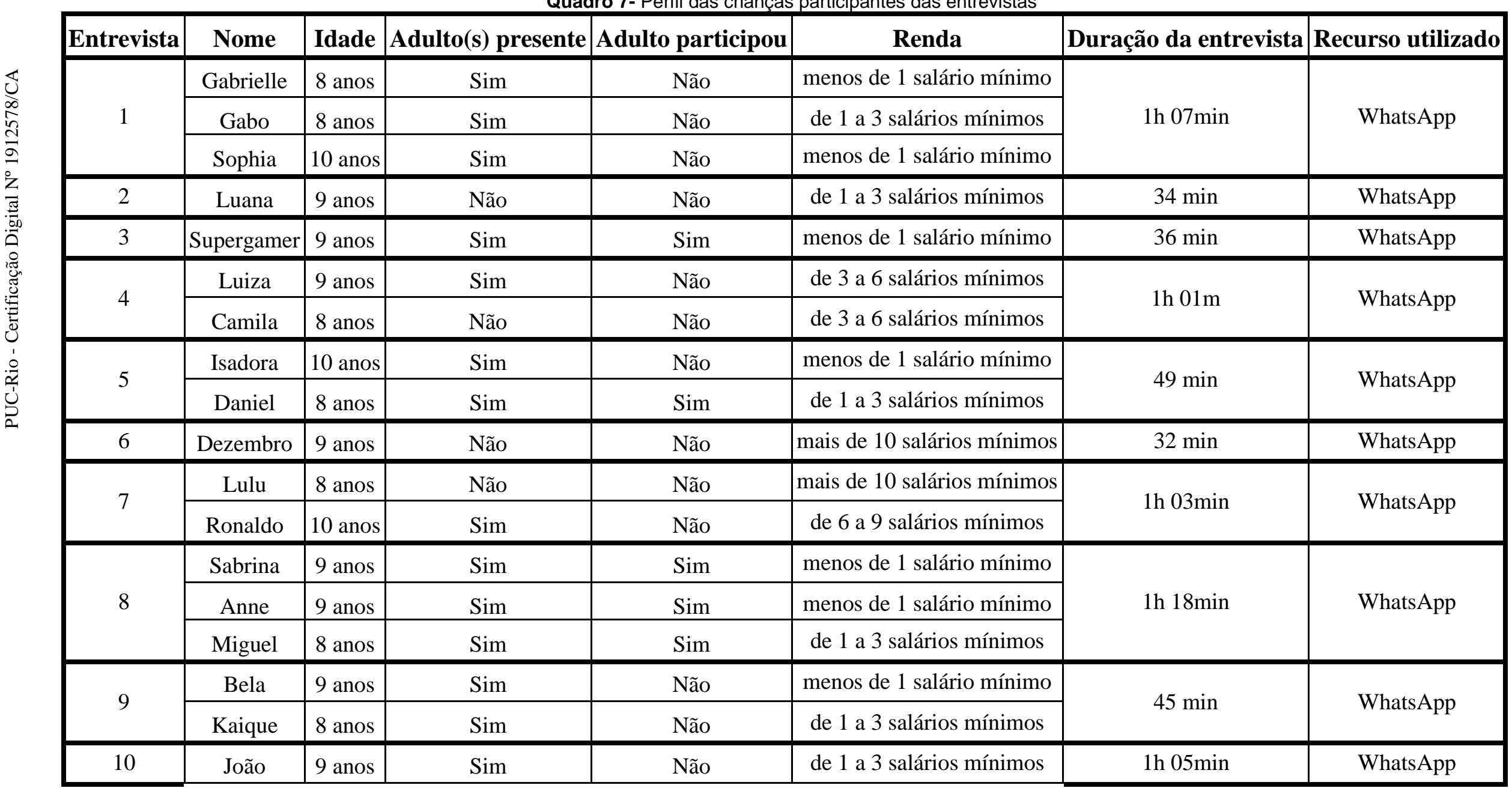




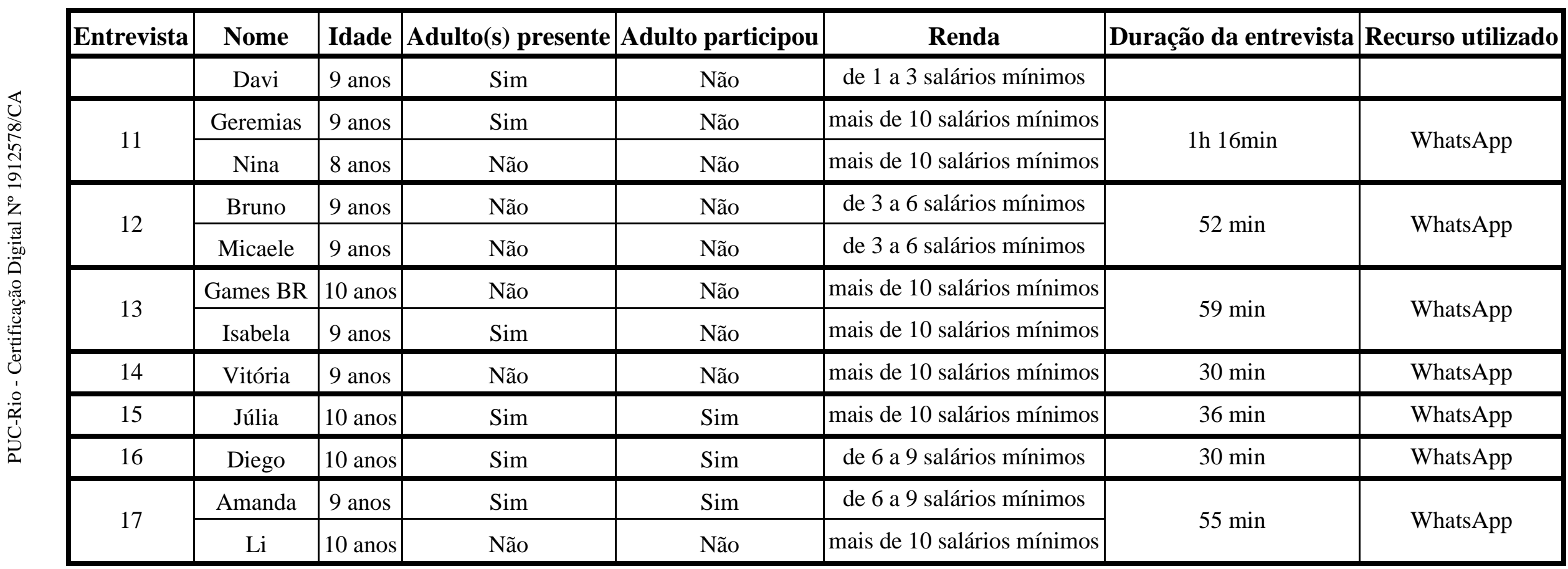




\subsection{3}

\section{Análise dos Dados}

A análise dos dados se iniciou com a organização das entrevistas no software ATLAS.ti (2002), em sua versão número 8. Duarte (2004) aponta a importância do uso de software para uma análise de entrevistas mais rigorosa e organizada, sobretudo quando são numerosas. As entrevistas não foram transcritas em um primeiro momento, pois o ATLAS.ti permite a análise de áudios gravados.

Foi utilizado o método de análise temática, segundo os princípios de Braun e Clark (2006). De acordo com os autores, a análise temática "é um método para identificar, analisar e relatar padrões (temas) dentro dos dados. Ela minimamente organiza e descreve o conjunto de dados em (ricos) detalhes." (BRAUN; CLARKE, 2006, p. 81). Apesar de os autores fornecerem diretrizes de etapas para auxiliar na realização da análise, eles ressaltam que uma de suas principais características é a flexibilidade, podendo ser adaptada de acordo com os fundamentos teóricos e metodológicos utilizados.

Os estágios da análise apresentados por Braun e Clarke são guias, mas não são lineares e exigem um processo de idas e vindas, conforme a necessidade do pesquisador. Os seis estágios descritos por eles são: 1) Familiarizando-se com seus dados; 2) Gerando códigos iniciais; 3) Buscando por temas; 4) Revisando temas; 5) Definindo temas; 6) produzindo relatório. Explicarei a seguir como realizamos o processo de análise, tendo como bases esses estágios, mas flexibilizando-os, de acordo com nossa necessidade teórica e metodológica.

Após a organização e familiarização com todo o material, foi realizada a codificação da primeira entrevista de forma indutiva - ou seja, os códigos foram criados de acordo com as temáticas vindas dos próprios dados. Cada código gerado foi definido e organizado em um mapa de códigos (ou manual de códigos).

A fim de verificar a fidedignidade dos códigos criados, foi realizado um teste de confiabilidade com uma aluna de graduação, integrante do grupo de pesquisa, que não teve contato prévio com os dados. Nesse teste, a integrante recebeu uma entrevista no ATLAS.ti com os trechos de áudio selecionados e nenhum código aplicado. A codificadora aplicou os códigos no próprio software e então verificarmos as concordâncias e divergências entre nossas codificações. Esse processo 
resultou em uma taxa de $81 \%$ de concordância, que, segundo Bauer e Gaskell (2008), pode ser considerada alta e, portanto, aceitável.

Em seguida, as demais entrevistas foram codificadas por mim. Nesse percurso, mais códigos foram sendo criados a partir dos dados. Posteriormente, a maior parte desses códigos foram agrupados em grandes categorias temáticas construídas a partir do referencial teórico utilizado nesta pesquisa. Assim, geramos o eixo temático central, que foi chamado de "As Culturas Infantis". Já os outros códigos foram agrupados em categorias provenientes dos próprios dados, formando o eixo chamado "O YouTube". Essa mistura de abordagem de códigos e categorias criados de formas indutivas e dedutivas é comum nas pesquisas que possuem um forte quadro teórico por trás (GIBBS, 2009).

Ao final dos estágios de revisão e definição de categorias temáticas, segue o mapa temático produzido:

Figura 10 - Mapa temático das categorias de análise

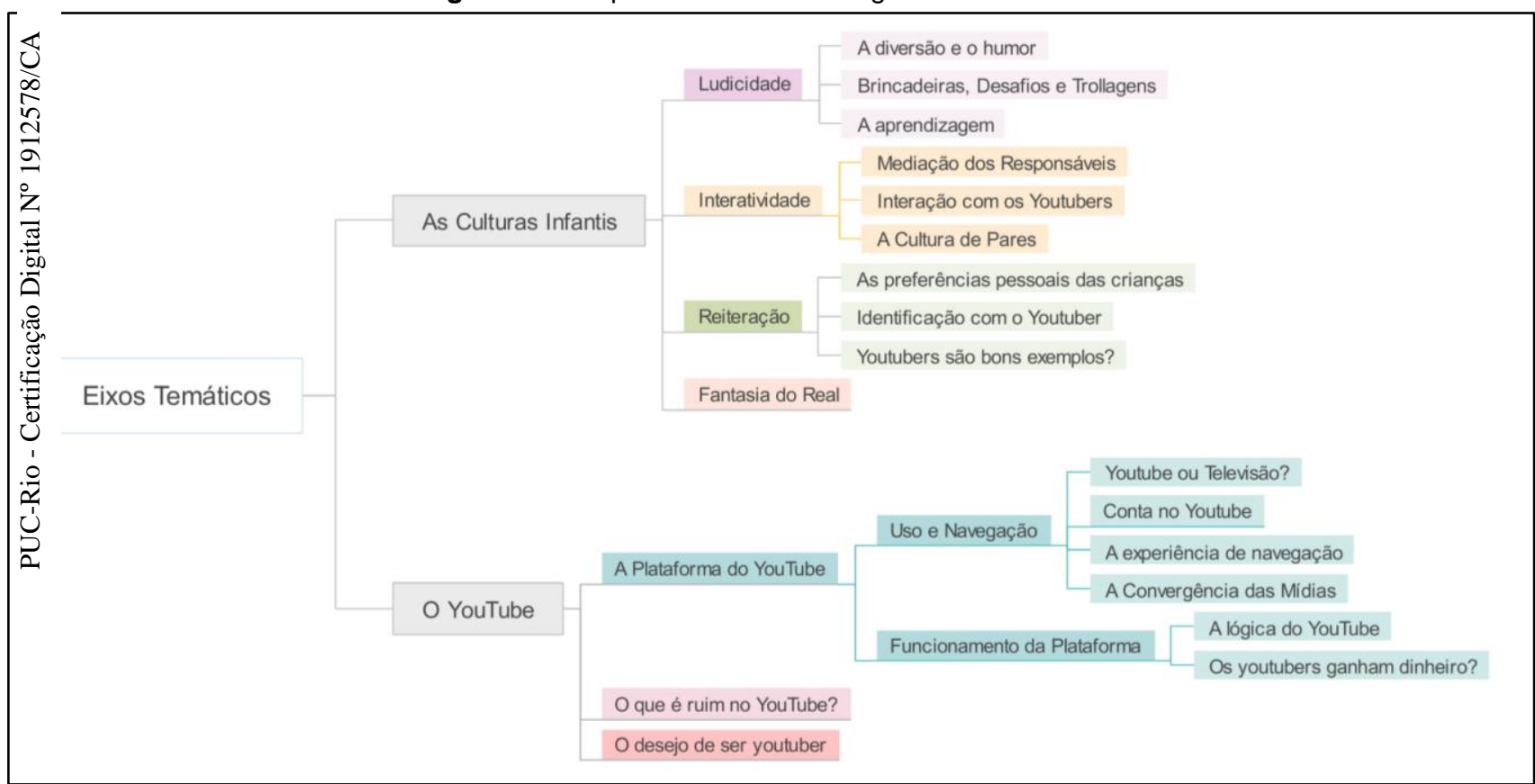

Fonte: elaborado pela autora

\section{4}

\section{Aspectos Éticos}

A presente pesquisa está de acordo com a Resolução 510/2016 (MINISTÉRIO DA SAÚDE, 1996, 2016), levando em consideração os princípios e cuidados 
éticos necessários nas pesquisas com humanos, em especial com as crianças. A pesquisa foi submetida à Câmara de Ética da Pontifícia Universidade Católica do Rio de Janeiro e foi protocolada sob o número 127/2019 (ver Anexo 2). Todos os aspectos éticos estão explicitados no Termo de Consentimento Livre e Esclarecido (Apêndice 3), contendo as informações completas sobre a pesquisa em uma linguagem clara e acessível para os pais ou responsáveis das crianças participantes.

A Resolução 510/2016 aponta também que o anonimato dos participantes seja garantido, preservando sua identidade e privacidade. Para isso, foi necessário, além do uso de códigos para falar das escolas e nomes fictícios para as crianças, imagens e sons apenas previamente autorizados, e a exclusividade do uso de dados apenas para a pesquisa.

Além da ética assegurada pelo pesquisador com o participante, essa pesquisa também assume a responsabilidade do compromisso com a verdade, sem manipulação de dados e se mantendo fiel ao que for encontrado. Sabemos que a neutralidade do pesquisador não existe, mas ter essa consciência é essencial para evitarmos um possível viés na construção da pesquisa e produção dos dados. 


\section{6}

\section{Resultados e Discussão}

Os achados desta pesquisa serão apresentados em 3 partes neste capítulo. A primeira parte será dedicada a apresentar os resultados encontrados da Etapa I da pesquisa, que se caracteriza como uma etapa quantitativa, tendo o levantamento como instrumento. A segunda e a terceira partes apresentarão os resultados da Etapa II da pesquisa, produzidos a partir das entrevistas com as crianças. A segunda parte será dedicada a discutir o uso e a navegação das crianças no YouTube e de que forma elas entendem a lógica por trás da plataforma e dos vídeos a que assistem. A terceira parte terá como foco aprofundar a discussão das culturas infantis, buscando perceber de que forma as escolhas e justificativas das crianças no YouTube nos possibilitam pensarmos nas infâncias atuais.

\section{1}

\section{O que as crianças mais gostam de assistir no YouTube?}

Nesta seção, serão apresentados os resultados que respondem a quais tipos de vídeos e canais do YouTube as crianças preferem assistir. É importante ressaltar aqui que sempre que nos referimos a "crianças", estamos falando dos participantes de 8 a 10 anos do município do Rio de Janeiro, não querendo generalizar para outras crianças de outras partes do Brasil e do mundo, como se houvesse uma categoria única de infância. Por esse motivo, serão sempre abordadas as variáveis de gênero, idade e perfil da escola para a discussão dos resultados, não visando rotular as crianças, mas sim entender suas especificidades contextuais, algo essencial ao analisarmos a infância (JAMES; PROUT, 2005). 


\subsection{1}

\section{Os tipos de vídeos preferidos pelas crianças}

Conforme já apresentado no capítulo anterior, no levantamento realizado, as 344 crianças participantes selecionaram seus tipos de vídeos favoritos dentre uma lista de 25 opções, podendo selecionar quantas desejassem. Em média, as crianças selecionaram 8 opções. Abaixo podemos ver o quadro completo com todos os tipos de vídeos e a porcentagem de crianças que apontou cada tipo como um de seus favoritos, além de uma breve descrição de cada um deles.

Quadro 8 - Tipos de vídeos preferidos das crianças

\begin{tabular}{|c|c|c|}
\hline Tipos de Vídeos & Descrição & $\begin{array}{l}\% \text { de crianças que } \\
\text { marcaram este tipo }\end{array}$ \\
\hline engraçados & $\begin{array}{l}\text { vídeos engraçados em geral, focados em } \\
\text { humor e/ou situações divertidas }\end{array}$ & $73 \%$ \\
\hline trollagem & $\begin{array}{l}\text { vídeos de pegadinhas, onde uma pessoa } \\
\text { geralmente faz uma pegadinha com outra, } \\
\text { como contar alguma informação falsa, en- } \\
\text { ganar de alguma forma e depois falar que } \\
\text { era só uma brincadeira }\end{array}$ & $70 \%$ \\
\hline gameplay (jogos) & $\begin{array}{c}\text { vídeos focados em jogos, geralmente jogos } \\
\text { de celular, computador e/ou videogame, } \\
\text { muitas vezes no estilo "gameplay", onde o } \\
\text { youtuber filma a tela enquanto joga o jogo e } \\
\text { conversa com os espectadores }\end{array}$ & $68 \%$ \\
\hline desafio & $\begin{array}{l}\text { vídeos que apresentam desafios diversifi- } \\
\text { cados, geralmente envolvendo brincadei- } \\
\text { ras, testes de quem consegue fazer mais } \\
\text { tempo/vezes alguma coisa e/ou situações } \\
\text { complicadas }\end{array}$ & $67 \%$ \\
\hline slime & $\begin{array}{c}\text { slime é uma massa gelatinosa maleável e } \\
\text { colorida como a geleca ou a amoeba; os ví- } \\
\text { deos consistem geralmente em ensinar a } \\
\text { como fazer diferentes tipos de slimes com } \\
\text { materiais diferentes }\end{array}$ & $44 \%$ \\
\hline memes & $\begin{array}{l}\text { meme é geralmente uma foto, vídeo ou } \\
\text { frase que viraliza na internet, se tornando } \\
\text { conhecido e geralmente contendo humor; } \\
\text { os vídeos de memes muitas vezes consis- } \\
\text { tem nos youtubers reagindo a diversos me- } \\
\text { mes, comentando e rindo }\end{array}$ & $44 \%$ \\
\hline top 10 & $\begin{array}{c}\text { vídeos que elencam } 10 \text { coisas de alguma } \\
\text { categoria, como por exemplo "os } 10 \text { luga- } \\
\text { res mais perigosos do mundo" ou "top } 10 \\
\text { animais fofos" }\end{array}$ & $44 \%$ \\
\hline paródia & $\begin{array}{l}\text { paródias geralmente são músicas conheci- } \\
\text { das que têm suas letras alteradas para al- } \\
\text { gum outro tema, geralmente contendo hu- } \\
\text { mor e/ou críticas de situações cotidianas }\end{array}$ & $43 \%$ \\
\hline curiosidades & $\begin{array}{l}\text { vídeos de curiosidades geralmente apre- } \\
\text { sentam fatos e/ou informações curiosas so- } \\
\text { bre a vida, podendo ser com teor histórico, } \\
\text { científico ou apenas humorístico }\end{array}$ & $42 \%$ \\
\hline
\end{tabular}




\begin{tabular}{|c|c|c|}
\hline Tipos de Vídeos & Descrição & $\begin{array}{l}\% \text { de crianças que } \\
\text { marcaram este tipo }\end{array}$ \\
\hline reação & $\begin{array}{l}\text { vídeos de reação são vídeos em que o you- } \\
\text { tuber reage à alguma coisa, como por } \\
\text { exemplo uma música, um vídeo, um jogo; o } \\
\text { vídeo consiste em assistir sua reação e opi- } \\
\text { niões sobre aquilo }\end{array}$ & $39 \%$ \\
\hline terror & $\begin{array}{c}\text { vídeos de terror variam bastante, podendo } \\
\text { ser realmente histórias de terror, como, por } \\
\text { exemplo, lendas urbanas, ou podem ter um } \\
\text { carácter mais de brincadeira, como alguém } \\
\text { fantasiado que persegue os youtubers, } \\
\text { dando sustos }\end{array}$ & $34 \%$ \\
\hline tutorial & $\begin{array}{c}\text { vídeos de tutoriais são aqueles que ensi- } \\
\text { nam a fazer alguma coisa, podendo ser por } \\
\text { exemplo de maquiagem, de como passar } \\
\text { uma fase no jogo ou mexer em algum apli- } \\
\text { cativo }\end{array}$ & $34 \%$ \\
\hline vlogs & $\begin{array}{c}\text { vlogs são vídeos que mostram principal- } \\
\text { mente o dia a dia do youtuber, sua rotina, } \\
\text { suas viagens etc; são vídeos geralmente } \\
\text { mais informais, em que o youtuber segura } \\
\text { a câmera com a mão e "leva" o espectador } \\
\text { para um dia com ele }\end{array}$ & $30 \%$ \\
\hline $\begin{array}{l}\text { perguntas e res- } \\
\text { postas (Q\&A) }\end{array}$ & $\begin{array}{c}\text { vídeos de perguntas e respostas consistem } \\
\text { no youtuber geralmente respondendo às } \\
\text { perguntas que os espectadores enviam; o } \\
\text { youtuber seleciona um número de pergun- } \\
\text { tas recebidas pelo YouTube, Instagram ou } \\
\text { outro meio e vai respondendo ao longo do } \\
\text { vídeo }\end{array}$ & $28 \%$ \\
\hline $\begin{array}{c}\text { faça você mesmo } \\
(D / Y)\end{array}$ & $\begin{array}{l}\text { DIY é uma sigla para "do it yourself", que } \\
\text { em português seria "faça você mesmo"; os } \\
\text { vídeos de DIY são ensinando a fazer algo } \\
\text { geralmente prático, como uma blusa custo- } \\
\text { mizada, uma capinha para o celular ou um } \\
\text { material escolar personalizado }\end{array}$ & $25 \%$ \\
\hline maquiagem & $\begin{array}{l}\text { vídeos de maquiagem geralmente são tuto- } \\
\text { riais, em que o youtuber ensina alguma } \\
\text { maquiagem; mas também pode ser apre- } \\
\text { sentando seus produtos de maquiagens } \\
\text { preferidos, fazendo resenhas de produtos, } \\
\text { ensinando truques etc. }\end{array}$ & $25 \%$ \\
\hline brinquedos & $\begin{array}{c}\text { vídeos de brinquedos geralmente consis- } \\
\text { tem em crianças brincando ou mostrando } \\
\text { alguns brinquedos - que podem ou não ter } \\
\text { sido enviados por empresas para a criança } \\
\text { fazer o vídeo }\end{array}$ & $24 \%$ \\
\hline videoaulas & $\begin{array}{c}\text { videoaulas são geralmente vídeos sobre te- } \\
\text { mas escolares, em que o youtuber de fato } \\
\text { dá uma aula sobre aquele tema, podendo } \\
\text { ser de matemática ou de inglês, por exem- } \\
\text { plo }\end{array}$ & $20 \%$ \\
\hline unboxing & $\begin{array}{l}\text { unboxing é um verbo em inglês que repre- } \\
\text { senta o ato de abrir, desembalar a embala- } \\
\text { gem de um produto; os vídeos de unboxing } \\
\text { consistem exatamente nisso, um youtuber } \\
\text { abrindo, por exemplo, uma caixa de pre- } \\
\text { sente, de brinquedo, de maquiagem, de um }\end{array}$ & $16 \%$ \\
\hline
\end{tabular}




\begin{tabular}{|c|c|c|}
\hline Tipos de Vídeos & Descrição & $\begin{array}{l}\% \text { de crianças que } \\
\text { marcaram este tipo }\end{array}$ \\
\hline & $\begin{array}{l}\text { jogo e mostrando tudo que vem na caixa e, } \\
\text { ao final, o produto }\end{array}$ & \\
\hline teatrinho & $\begin{array}{l}\text { vídeos de teatrinhos também são comu- } \\
\text { mente chamados de "vídeos de novelinhas" } \\
\text { ou "historinhas"; geralmente consistem nos } \\
\text { youtubers encenando alguma história de } \\
\text { determinada temática; pode ser em formato } \\
\text { de série, em que cada vídeo representa um } \\
\text { episódio daquela história }\end{array}$ & $10 \%$ \\
\hline favoritos do mês & $\begin{array}{c}\text { vídeos em que o youtuber apresenta suas } \\
\text { coisas favoritas daquele mês, podendo ser } \\
\text { produtos, maquiagens, jogos, roupas, fil- } \\
\text { mes, livres ou o que mais o youtuber quiser } \\
\text { mostrar; é um tipo de vídeo geralmente } \\
\text { feito mensalmente }\end{array}$ & $10 \%$ \\
\hline $\begin{array}{c}\text { perguntas fre- } \\
\text { quentes }\end{array}$ & $\begin{array}{c}\text { vídeos em que o youtuber responde às per- } \\
\text { guntas que são feitas com mais frequência } \\
\text { para ele, geralmente curiosidades e fatos } \\
\text { que os espectadores sempre perguntam e } \\
\text { querem saber }\end{array}$ & $8 \%$ \\
\hline $\begin{array}{c}\text { saúde, fitness e } \\
\text { bem-estar }\end{array}$ & $\begin{array}{c}\text { vídeos envolvendo as temáticas de dicas } \\
\text { de vida saudável, exercícios, dieta, medita- } \\
\text { ções ou outras práticas que envolvam esse } \\
\text { universo }\end{array}$ & $8 \%$ \\
\hline colaboração & $\begin{array}{c}\text { vídeos também chamados de "feat", que } \\
\text { consistem no youtuber convidando uma ou- } \\
\text { tra pessoa (youtuber ou não) para partici- } \\
\text { par daquele vídeo com ele; geralmente } \\
\text { quando o convidado é um outro youtuber, } \\
\text { saem vídeos de colaboração em ambos os } \\
\text { canais } \\
\end{array}$ & $7 \%$ \\
\hline review/resenha & $\begin{array}{c}\text { vídeos em que o youtuber faz uma resenha } \\
\text { de algum produto ou serviço, dizendo as } \\
\text { especificações e suas opiniões sobre um } \\
\text { jogo, um celular, uma maquiagem ou qual- } \\
\text { quer outra coisa }\end{array}$ & $7 \%$ \\
\hline
\end{tabular}

Fonte: elaborado pela autora

Esclareço que as crianças participantes não tiveram acesso a essas descrições. Durante o levantamento presencial na escola, poucas crianças apresentaram dúvidas sobre o que eram os tipos de vídeos, e assim que eu exemplificava para elas, a dúvida era esclarecida. A grande maioria das crianças pareciam já estar bastante familiarizadas com essas nomenclaturas. No levantamento online, as crianças que tivessem dúvidas poderiam perguntar para seus responsáveis ou até mesmo pesquisar aqueles tipos de vídeos.

Além dessas opções elencadas, as crianças também podiam escrever o nome de outros tipos de vídeos que não estavam na lista. No levantamento presencial, $30 \%$ das crianças acrescentaram alguma outra opção de tipo de vídeo, enquanto no levantamento online foram $37 \%$ das crianças. Os tipos mais citados foram os vídeos 
de futebol, citados por 26 crianças (8\% do total) e os vídeos de música, citados por 19 (6\%) crianças. Também foram trazidos: vídeos de desenhar (por 7 crianças), vídeos de esportes (6), vídeos de jogos específicos (6), como Freefire, por exemplo, e vídeos de desenhos e novelas (5).

Podemos observar no Quadro 8 que os únicos tipos de vídeos selecionados como preferidos pela maioria das crianças foram os vídeos engraçados, vídeos de trollagens, vídeo de jogos e vídeos de desafios - todos podendo ser caracterizados como vídeos com forte ênfase no lúdico. Fuenzalida (1997) em seus estudos sobre as motivações que as crianças têm para assistir televisão, já apontava para as preferências de programas lúdicos e humorísticos, tendência que vemos se repetindo agora no YouTube. A ludicidade é um dos eixos centrais que caracteriza as culturas infantis (BROUGÈRE, 1998; SARMENTO, 2003b), estando presente nas rotinas e lógicas das crianças independentemente da idade, gênero e grupos social.

Por conta da falta de estudos empíricos que propusessem levantamento semelhante, o diálogo com a literatura específica sobre o YouTube só pode ser feito em relação às temáticas mais presentes nos canais preferidos das crianças. Ribeiro (2020), por exemplo, encontra que a maior parte dos canais preferidos pelas crianças em sua pesquisa eram de jogos, enquanto na pesquisa de Araújo (2019) os canais mais citados tinham as temáticas trollagens, pegadinhas, desafios, compras e Minecraft.

A seguir, exploramos as variações de preferências das crianças por gênero, idade e perfil da escola; assim poderemos entender melhor as especificidades de cada grupo e aprofundar-nos nos tipos de vídeos mais citados.

\section{Gênero}

Conforme explicitado anteriormente, 6 das 344 crianças não declararam seu gênero no levantamento, então trabalharemos aqui com o total de 338 crianças que o fizeram, sendo elas 179 meninos e 159 meninas. O gênero é apontado por Corsaro (1990) como uma das primeiras variáveis responsáveis pela diferenciação entre os grupos de pares infantis. As crianças vivem em uma sociedade que tem expectativas sobre os comportamentos de meninas e meninos, que muitas vezes se refletem em papéis socialmente estereotipados, mas que são desafiados e ressignificados pelas crianças, e não absorvidos de forma passiva (CORSARO, 2009a). 
A fim de entender as diferenças e semelhanças nas preferências de tipos de vídeos do YouTube, elencamos os 10 tipos preferidos de cada um dos grupos, conforme mostra o quadro a seguir:

Quadro 9 - Tipos de vídeos preferidos por gênero

\begin{tabular}{|c|c|c|}
\cline { 2 - 3 } \multicolumn{1}{c|}{} & Meninos & Meninas \\
\hline $1^{\circ}$ & gameplay (jogos) & engraçados \\
\hline $2^{\circ}$ & engraçados & trollagem \\
\hline $3^{\circ}$ & trollagem & desafio \\
\hline $4^{\circ}$ & desafio & slime \\
\hline $5^{\circ}$ & paródia & maquiagem \\
\hline $6^{\circ}$ & memes & gameplay (jogos) \\
\hline $7^{\circ}$ & top 10 & top 10 \\
\hline $8^{\circ}$ & curiosidades & reação \\
\hline $9^{\circ}$ & terror & memes \\
\hline $10^{\circ}$ & reação & tutorial \\
\hline
\end{tabular}

Fonte: elaborado pela autora

Os tipos de vídeos coloridos na tabela são aqueles que aparecem em ambas as listas. Em relação aos meninos, podemos ver que os tipos de vídeos mais citados por eles como favoritos são os de jogos, que só vão aparecer na lista das meninas em $6^{\circ}$ lugar.

Porém, quando separamos as crianças por perfil da escola para uma análise mais profunda, vimos que as meninas do Grupo 2 (escolas de NSE mais elevado) têm os vídeos de jogos em $2^{\circ}$ lugar como preferidos, enquanto na lista das meninas do Grupo 1 (escola de NSE menos favorecido) ele só vai aparecer em $13^{\circ}$ lugar. $\mathrm{Ou}$ seja, o fato de os vídeos de jogos caírem de posição de $1^{\circ}$ para $6^{\circ}$ lugar quando comparamos os gêneros, parece acontecer mais em função das meninas de nível socioeconômico mais baixo do que das de NSE mais alto. O Quadro 10 ilustra essa diferença.

Quadro 10 - Tipos de vídeos por gênero e perfil de escola

\begin{tabular}{|c|c|c|c|c|c|}
\hline & \multicolumn{2}{|c|}{ Grupo 1} & & \multicolumn{2}{|c|}{ Grupo 2} \\
\hline & Meninos & Meninas & & Meninos & Meninas \\
\hline $1^{\circ}$ & gameplay (jogos) & desafio & 10 & gameplay (jogos) & engraçados \\
\hline $2^{\circ}$ & desafio & trollagem & $2^{\circ}$ & engraçados & gameplay (jogos) \\
\hline 3은 & engraçados & slime & 3응 & trollagem & trollagem \\
\hline $4^{\circ}$ & trollagem & engraçados & 49 & curiosidades & desafio \\
\hline
\end{tabular}




\begin{tabular}{|c|c|c|c|c|c|}
\hline $5^{\circ}$ & paródia & maquiagem & 5웅 & Top 10 & slime \\
\hline $6^{0}$ & memes & reação & 6은 & desafio & $D / Y$ \\
\hline $7^{0}$ & terror & Top 10 & $7^{0}$ & tutorial & curiosidades \\
\hline $8^{0}$ & Top 10 & vlogs & $8^{\circ}$ & paródia & Top 10 \\
\hline $9^{\circ}$ & curiosidades & memes & 9용 & memes & memes \\
\hline $10^{\circ}$ & reação & tutorial & $10^{\circ}$ & perguntas e respostas & maquiagem \\
\hline
\end{tabular}

Essa preferência por vídeos de jogos corrobora com os achados de pesquisas anteriores sobre os conteúdos dos canais preferidos por meninos (BEZERRA, 2018; RIBEIRO, 2020), mas ainda não tinha sido constatada em uma escala maior. Destacamos ainda os vídeos de paródia, de curiosidades e de terror, que aparecem exclusivamente na lista dos 10 tipos preferidos pelos meninos.

Por outro lado, na lista dos tipos preferidos das meninas, temos os vídeos de slime, maquiagem e tutorial, que não apareceram para os meninos. Os vídeos de slime tinham sido relatados como preferidos pelas meninas na pesquisa de Bezerra (2018), enquanto que aqui eles se encontram em $4^{\circ}$ lugar na lista. Uma hipótese para explicar essa diferença é de que os vídeos de slime estavam no auge de sua popularidade nos anos em que a pesquisa de Bezerra havia sido realizada, tendo perdido um pouco de destaque nos últimos anos.

Corsaro (1990) destaca a importância de olharmos não apenas para as diferenças entre os gêneros, mas também para o que os aproxima. Vimos que os vídeos engraçados, de trollagem e de desafios, aparecem nos primeiros lugares de ambas as listas, podendo ser apontados como os tipos de vídeos preferidos das crianças independentemente de gênero. Os vídeos de memes, top 10 e de reação também podem ser apontados como preferidos por ambos os gêneros.

Buscando uma análise mais robusta das diferenças de gêneros, foi realizado um teste estatístico de Qui-Quadrado (ver Tabela 3) para verificar quais preferências de tipos de vídeo estão de fato associadas com a variável de gênero.

Tabela 3 - Qui-Quadrado por gênero

\begin{tabular}{|c|c|c|c|c|c|c|}
\hline \multirow{2}{*}{ Tipos de vídeos } & \multicolumn{2}{|c|}{ Meninos } & \multicolumn{2}{|c|}{ Meninas } & \multirow{2}{*}{ Qui-Quadrado } & \multirow{2}{*}{ valor de $\mathrm{p}$} \\
\cline { 2 - 5 } & $\mathbf{n}(\mathbf{1 7 9})$ & $\%$ & $\mathbf{n}(\mathbf{1 5 9 )}$ & $\%$ & & \\
\hline gameplay (jogos) & 158 & $88 \%$ & 73 & $46 \%$ & 69,824 & $\mathrm{p}<0,001^{*}$ \\
\hline paródia & 92 & $51 \%$ & 55 & $35 \%$ & 9,676 & $\mathrm{p}=0,002^{*}$ \\
\hline tutorial & 51 & $28 \%$ & 65 & $41 \%$ & 5,734 & $\mathrm{p}=0,022^{*}$ \\
\hline vlogs & 42 & $23 \%$ & 61 & $38 \%$ & 8,825 & $\mathrm{p}=0,003^{*}$ \\
\hline
\end{tabular}




\begin{tabular}{|c|c|c|c|c|c|c|}
\hline slime & 38 & $21 \%$ & 110 & $69 \%$ & 78,666 & $\mathrm{p}<0,001^{*}$ \\
\hline brinquedos & 33 & $18 \%$ & 48 & $30 \%$ & 6,383 & $\mathrm{p}=0,015^{*}$ \\
\hline DIY & 27 & $15 \%$ & 56 & $35 \%$ & 18,429 & $\mathrm{p}<0,001^{*}$ \\
\hline maquiagem & 3 & $2 \%$ & 81 & $51 \%$ & 109,439 & $\mathrm{p}<0,001^{*}$ \\
\hline $\begin{array}{l}\text { df = 1 } \\
{ }^{*} \text { Probabilidade significativa a 5\% }\end{array}$ \\
\hline \multicolumn{7}{c|}{ Fonte: elaborado pela autora }
\end{tabular}

Os tipos que apresentaram diferenças significativas foram: jogos, paródias, tutorial, vlogs, slime, brinquedos, DIY e maquiagem. O Gráfico 5 - Tipos de vídeos com diferenças significativas por gênero

Gráfico 5213 demostra as diferenças percentuais entre os grupos de meninos e meninas.

Gráfico 5 - Tipos de vídeos com diferenças significativas por gênero

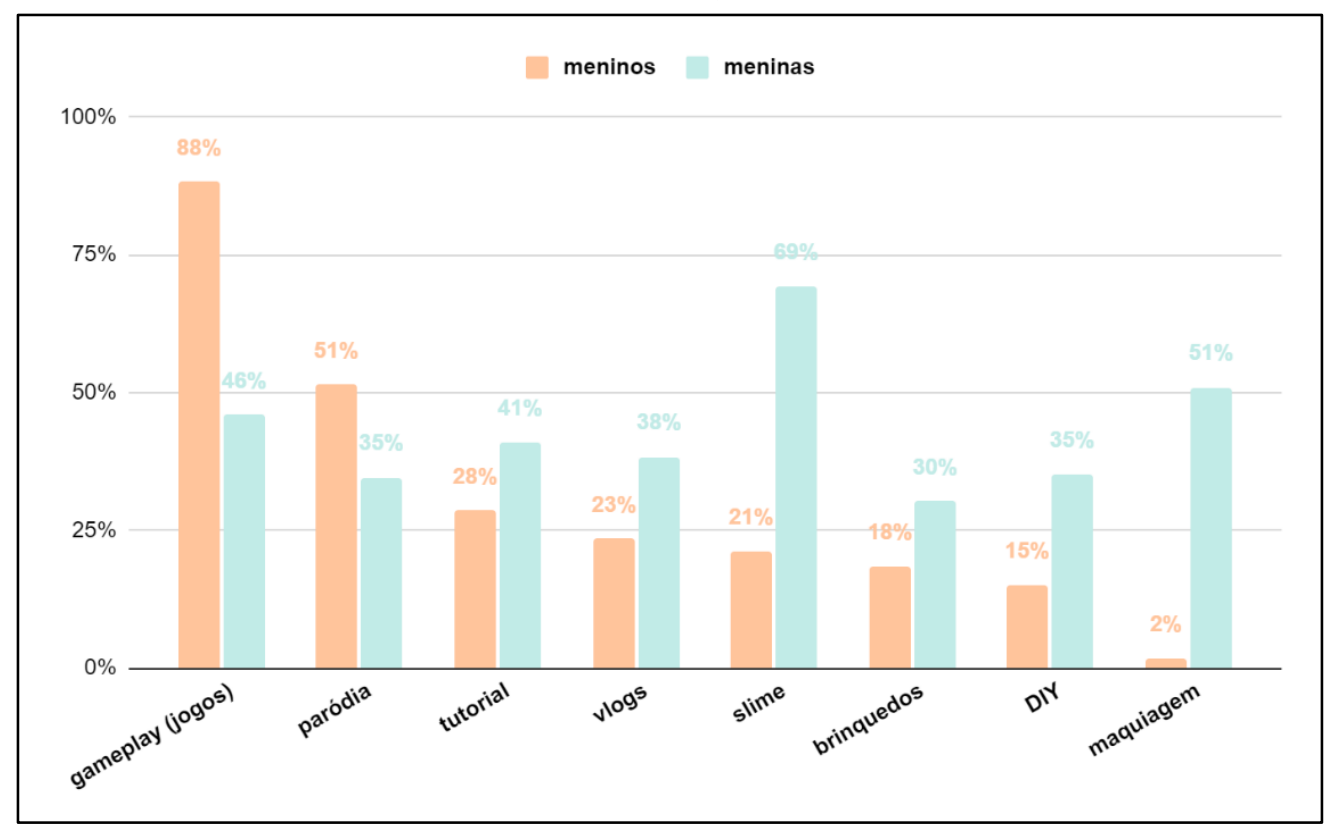

Fonte: elaborado pela autora

A partir da distribuição mostrada no gráfico, é possível constatar que os vídeos de jogos e de paródias são de fato mais citados como preferidos no grupo dos meninos. Conforme será discutido nos próximos capítulos, o fato de os vídeos de jogos serem preferidos pelos meninos corrobora com os estereótipos de que eles gostam mais de vídeo games, jogos de aventura e ação do que as meninas, que, por sua vez, se interessariam mais por maquiagem, por exemplo. No entanto, devemos notar que os youtubers que produzem vídeos sobre jogos parecem ser geralmente 
homens, o que talvez faça com que mais meninos se interessem pela temática do que as meninas.

Contudo, é importante ressaltar que os jogos aparecem também na lista dos 10 tipos de vídeos preferidos pelas meninas, enquanto maquiagem não aparece na dos meninos e apresenta uma variação percentual bem mais acentuada. A constatação de que meninas transitam mais por atividades ditas "de meninos" do que o inverso, também foi encontrada por Becker (2013) em sua pesquisa sobre atividades lúdicas online. Em geral, os meninos são mais julgados negativamente quando realizam atividades consideradas "de menina" do que o contrário (MARTIN, 1990), desafiando, assim, menos os estereótipos de gêneros do que as meninas (KARSTEN, 2003).

Novamente, há que se considerar a identidade de gênero - talvez existam mais mulheres compartilhando vídeos de maquiagem do que homens, o que pode gerar uma maior identificação das meninas e consequente preferência pela temática.

Ainda em relação às meninas, vimos que, com exceção dos $v \log s$, os outros tipos de vídeos que apresentaram diferenças significativas apresentam um caráter de atividades mais práticas. Maquiagem, DIY, brinquedos, slime e tutoriais são categorias de vídeos que muitas vezes se propõem a ensinar a fazer algo ou demonstrar algum tipo de uso daquele objeto. Paródias e $v \log s$, por outro lado, podem ser vistos como vídeos mais puramente de entretenimento, enquanto vídeos de jogos poderiam se encaixar em uma categoria ou em outra, dependendo da abordagem.

Outro apontamento importante sobre o gênero é que os meninos tendem a concentrar sua preferência em um mesmo tipo de vídeo, enquanto as meninas apresentam uma maior distribuição dentre as opções existentes. Este achado corrobora os resultados da pesquisa de Karsten (2003), que encontra que os meninos se concentram em torno de uma atividade principal, que no caso era o futebol, enquanto as meninas variavam mais suas preferências de brincadeiras. Dentre os meninos, 88\% apontaram ter os vídeos de jogos como um dos preferidos, demostrando uma forte preferência por essa temática. Já entre as meninas, houve um empate de preferência entre vídeos engraçados e de trollagem, cada um com $73 \%$ de frequência, e, logo em seguida, os vídeos de desafio, com $72 \%$. Assim, podemos entender que a variedade de preferência entre as meninas se encontra um pouco mais diluída.

\section{$\underline{\text { Idade }}$}


Corsaro (1990) também aponta a idade das crianças como uma variável importante de ser considerada nas análises da infância. Neste estudo, porém, a faixa etária das crianças participantes foi restrita, de 8 a 10 anos de idade. Possivelmente por esse motivo, os resultados não apresentaram grandes variações entre as idades. Retomando, foram 104 crianças de 8 anos, 113 de 9 anos e 127 de 10 anos. No quadro a seguir é possível ver os dez vídeos mais citados como preferidos por cada uma das faixas etárias:

Quadro 11 - Tipos de vídeos preferidos por idade

\begin{tabular}{|c|c|c|c|}
\hline & 8 anos & 9 anos & 10 anos \\
\hline $1^{\circ}$ & engraçados & engraçados & engraçados \\
\hline $2^{\circ}$ & trollagem & desafio & trollagem \\
\hline $3^{\circ}$ & gameplay (jogos) & gameplay (jogos) & gameplay (jogos) \\
\hline $4^{\circ}$ & desafio & trollagem & desafio \\
\hline $5^{\circ}$ & slime & curiosidades & top 10 \\
\hline $6^{\circ}$ & reação & memes & memes \\
\hline $7^{\circ}$ & curiosidades & slime & paródia \\
\hline $8^{\circ}$ & paródia & paródia & vlogs \\
\hline $9^{\circ}$ & top 10 & top 10 & reação \\
\hline $10^{\circ}$ & terror & tutorial & curiosidades \\
\hline
\end{tabular}

Novamente, estão coloridos apenas os tipos de vídeos que aparecem nas listas de vídeos preferidos de todas as idades. Podemos perceber primeiramente que os 4 primeiros vídeos preferidos são os mesmos entre todas as crianças, mudando apenas a ordem de preferência em alguns casos. Isso também acontece com os vídeos de curiosidades, paródias, e top 10, mostrando que a preferência por idade realmente não varia tanto dentro dessa faixa etária.

Entretanto, os vídeos de slime, que aparecem em $5^{\circ}$ lugar para as crianças de 8 anos, em $7^{\circ}$ para as de 9 e nem chegam a aparecer na lista dos preferidos das de 10 anos, mostram preferência entre as crianças mais jovens. Esse resultado foi corroborado com o teste estatístico de Qui-Quadrado (ver Tabela 4), que apontou a diferença de idade como significativa para a preferência por vídeos de slime entre as crianças. Assim também acontece com os vídeos de brinquedos, mostrando que as crianças possivelmente vão deixando de gostar de tais tipos de vídeos conforme 
crescem. Ambos são tipos de vídeos bastante lúdicos e práticos, que de fato podem atrair mais os mais novos.

Tabela 4 - Qui-Quadrado por idade

\begin{tabular}{|c|c|c|c|c|c|c|c|c|}
\hline \multirow{2}{*}{$\begin{array}{l}\text { Tipos de ví- } \\
\text { deos }\end{array}$} & \multicolumn{2}{|c|}{8 anos } & \multicolumn{2}{|c|}{9 anos } & \multicolumn{2}{|c|}{10 anos } & \multirow{2}{*}{$\begin{array}{c}\text { Qui-Qua- } \\
\text { drado }\end{array}$} & \multirow{2}{*}{$\begin{array}{c}\text { valor de } \\
\text { p }\end{array}$} \\
\hline & $\begin{array}{c}n \\
(104)\end{array}$ & $\%$ & $\begin{array}{c}\mathbf{n} \\
(113)\end{array}$ & $\%$ & $\begin{array}{c}\mathbf{n} \\
(127)\end{array}$ & $\%$ & & \\
\hline slime & 59 & $57 \%$ & 52 & $46 \%$ & 41 & $32 \%$ & 14,086 & $\mathrm{p}=0,001^{*}$ \\
\hline brinquedos & 39 & $38 \%$ & 26 & $23 \%$ & 18 & $14 \%$ & 17,111 & $\mathrm{p}<0,001^{*}$ \\
\hline$D / Y$ & 30 & $29 \%$ & 34 & $30 \%$ & 22 & $17 \%$ & 6,373 & $\mathrm{p}=0,041^{*}$ \\
\hline vídeo-aulas & 27 & $26 \%$ & 26 & $23 \%$ & 15 & $12 \%$ & 8,334 & $\mathrm{p}=0,016^{*}$ \\
\hline colaboração & 15 & $14 \%$ & 7 & $6 \%$ & 3 & $2 \%$ & 12,629 & $\mathrm{p}=0,002^{*}$ \\
\hline
\end{tabular}

Os outros tipos de vídeos que se mostraram associados com a variável de idade foram os vídeos de DIY, de colaboração e as videoaulas. Para esses, porém, não encontramos um padrão claro de variação, nem justificativas teóricas ou empíricas para tal relevância. Importante ressaltar novamente que aqui estamos trabalhando com a faixa etária de 8 a 10 anos, mas que outras pesquisas que envolvam crianças de idades mais diferentes seriam necessárias para explorar mais a variável de idade.

\section{$\underline{\text { Perfil de escola }}$}

Em relação à análise do perfil da escola, lembro o que já foi explicitado no capítulo de metodologia: o levantamento da escola que atende crianças de NSE mais baixo foi aplicado presencialmente em uma única escola, enquanto o das escolas que atendem NSE mais elevados foi distribuído de forma online. Por conta dessa divergência metodológica, serão feitos aqui apenas apontamentos e levantamentos de hipóteses, sendo também necessário futuras pesquisas para dar maior robustez a esses resultados.

A primeira divergência em função da metodologia está na quantidade de crianças participantes. Foram 236 crianças que estudam na escola de caráter filantrópico (Grupo 1) e 108 crianças de escolas de elite (Grupo 2). Outra diferença foi que as crianças que preencheram presencialmente na escola o levantamento marcaram uma média maior de opções de tipos de vídeos preferidos (média = 9,3 marcações) 
do que as crianças que preencheram virtualmente (média = 5,8 marcações). Uma hipótese para explicar esta discrepância é de que as crianças que preencheram o questionário presencialmente podiam tirar suas dúvidas comigo, além de talvez terem dedicado mais tempo para o preenchimento do levantamento.

Levando essas diferenças em consideração, vamos olhar os 10 tipos de vídeos preferidos de cada um dos grupos pesquisados:

Quadro 12 - Tipos de vídeos preferidos por perfil da escola

\begin{tabular}{|c|c|c|}
\hline & Grupo 1 & Grupo 2 \\
\hline $1^{\circ}$ & desafio & engraçados \\
\hline $2^{0}$ & trollagem & gameplay (jogos) \\
\hline $3^{0}$ & engraçados & trollagem \\
\hline $4^{\circ}$ & gameplay (jogos) & desafio \\
\hline $5^{0}$ & slime & curiosidades \\
\hline $6^{0}$ & paródia & Top 10 \\
\hline $7^{0}$ & memes & memes \\
\hline $8^{\circ}$ & Top 10 & tutorial \\
\hline $9^{\circ}$ & reação & slime \\
\hline $10^{\circ}$ & terror & $D / Y$ \\
\hline
\end{tabular}

Observando o quadro, podemos ver novamente que os quatro primeiros lugares são os mesmos, apesar de mudarem sua ordem de um grupo para o outro. Os vídeos de jogos apareceram em $2^{\circ}$ lugar para crianças do Grupo 2 e em $4^{\circ}$ para crianças do Gripo 1. Essa pequena variação talvez possa se justificar pela diferença no poder aquisitivo entre os dois grupos para comprar vídeo games ou jogos mais caros. Ribeiro (2020) encontrou em sua pesquisa que as crianças de escola pública mencionaram menos o jogo como uma atividade que realizam na internet do que as de escolas particulares, corroborando com o achado desta pesquisa. Mas, lembremos novamente que são as meninas do Grupo 1 que estão impactando essa queda, uma vez que só vão apresentar a preferência por jogos em $13^{\circ}$ lugar, enquanto os meninos deste grupo também têm os jogos como favoritos em $1^{\circ}$ lugar.

Por outro lado, os vídeos de slime podem apresentar uma possibilidade de entretenimento financeiramente mais acessível, uma vez que o slime pode ser feito tanto com materiais caros e difíceis de encontrar quanto com ingredientes caseiros e mais baratos. Apesar dessas divergências na posição desses tipos de vídeos na 
lista, o que chama mais nossa atenção é que ambos aparecem nos dois grupos, o que indica que as crianças de níveis socioeconômicos diferentes estão consumindo mais ou menos os mesmos tipos de vídeos.

As divergências maiores estão nos vídeos de paródia, reação e terror, que aparecem na lista das crianças do Grupo 1, mas não nas do Grupo 2. Paródia e reação irão aparecer logo em seguida, nas posições $11^{\circ}$ e $12^{\circ}$ respectivamente. Os vídeos de terror são os que chamam mais atenção, pois só aparecerão em $19^{\circ}$ lugar na lista das crianças do Grupo 2, indicando uma possível diferença na preferência. Uma explicação possível para esse fenômeno é que as crianças que responderam o levantamento na escola tiveram mais liberdade para responderem "terror" como um tipo de vídeo de que gostavam, já que não tinham a supervisão dos responsáveis no momento. Os vídeos de terror podem ser vistos como inapropriados para essa idade, o que poderia impedir as crianças de relatarem gostar desse tipo de vídeo na presença de seus responsáveis.

Já na lista das crianças do Grupo 2, aparecem os vídeos de curiosidade, de tutoriais e de DIY, todos se configurando como vídeos que podem ensinar alguma coisa de forma mais direta para as crianças. Os vídeos de curiosidades geralmente trazem informações sobre fatos curiosos e os vídeos de tutoriais e DIY podem ensinar a como fazer algo. Como não temos outros estudos similares que trabalharam com a variável de nível socioeconômico, uma hipótese é a de que talvez as crianças do Grupo 2 sejam mais direcionadas a assistirem vídeos considerados mais "relevantes" pelos seus responsáveis, que talvez prefiram que elas assistam a vídeos que ensinem algo para elas. Os responsáveis que possuem níveis mais altos de escolaridade relatam mediar de forma mais ativa o uso que as crianças fazem na internet, segundo as pesquisas do TIC KIDS Brasil (2020). Essas hipóteses e achados terão mais força quando articulados aos dados encontrados nas entrevistas com as crianças, onde de fato foi possível explorar os motivos declarados pelas crianças de preferirem ou não determinado tipo de vídeo.

Outro achado interessante nestes dados foi que, ao realizar alguns cruzamentos entre as variáveis de gênero, idade e perfil da escola, pudemos perceber que as crianças das escolas de NSE mais elevado parecem compartilhar mais preferências em comum independente de idade e gênero. Esse parece ser um resultado contra intuitivo, considerando que as crianças do Grupo 1 (NSE mais baixos) eram de uma mesma escola e, portanto, poderia se esperar que teriam maior compartilhamento 
de preferências entre elas, enquanto as do Grupo 2 (NSE mais elevado) nem mesmo se conheciam. Guardaremos esse dado para a discussão, que será realizada mais à frente sobre as preferências pessoais de cada criança, que independem da preferência de seus pares próximos. Além disso, os meninos também parecem ter essa cultura de compartilhamento de preferências mais forte do que as meninas, principalmente por conta dos vídeos de jogos, que é o tipo preferido deles independente de perfil da escola e idade.

Vimos, então, que aquilo que aproxima as crianças e que parece serem as categorias de vídeos que mais lhes agradam são os vídeos de desafios, engraçados e de trollagem, todos com forte aspecto lúdico. Os vídeos de jogos também se configuram como bastante apreciados pelas crianças, com exceção das meninas da escola de NSE mais baixo. Destaco também os vídeos de slime, que são trazidos como um dos preferidos principalmente pelas meninas mais novas e de escola de NSE menos favorecido. Os vídeos com características mais práticas como slime, DIY, maquiagem e tutoriais são mais trazidos como preferidos pelas meninas, enquanto os meninos parecem se interessar mais pelos vídeos de humor, como de paródia e reação. Por último, aponto de novo uma possível preferência das crianças de escolas de NSE mais elevado pelos vídeos mais informativos, como por exemplos os de curiosidade. A seguir, veremos quais são os canais preferidos das crianças, o que nos ajudará a ampliar essa análise.

\section{1 .2}

\section{Os canais preferidos das crianças}

Após entender quais são os tipos de vídeos a que as crianças mais gostam de assistir, vamos nos debruçar agora sobre seus canais preferidos no YouTube, onde geralmente assistem a esses tipos de vídeos. As crianças participantes poderiam escrever no levantamento até 3 canais preferidos. Assim, algumas escreveram apenas 1 canal, outras 2 ou 3 e ainda houve algumas que optaram por ultrapassar o limite proposto e escreveram 4 ou 5 canais. Oito das 344 crianças deixaram em branco essa opção. A média de canais citados por criança foi de 2,6 no levantamento Grupo 1 (NSE mais baixo) e de 2,3 no Grupo 2 (NSE mais alto), sendo a média total de 2,45 canais citados por criança. 
Nossa primeira observação é que aproximadamente $14 \%$ das crianças participantes fizeram algum tipo de confusão na hora de escrever seus canais preferidos, colocando, por exemplo, outros tipos de vídeos ou nomes de desenhos animados, e não nomes de canais. Algumas escreveram um canal e um tipo de vídeo, outras simplesmente repetiram aquelas opções que haviam marcado como tipos de vídeos preferidos. Isso pode indicar que algumas crianças talvez não estivessem tão familiarizadas com a plataforma do YouTube, não identificando tão bem a diferença entre canais e tipos de vídeos.

Houve ainda $12 \%$ das crianças que citaram nomes dos youtubers protagonistas do canal, e não o nome do canal em si. Por exemplo, o canal "Crescendo com Luluca" foi diversas vezes referido como simplesmente "Luluca", o que pode representar uma simples abreviação do nome ou indicar que a figura daquela youtuber talvez seja mais significativa para a criança do que o nome do canal.

Antes de apresentarmos os canais mais citados, é essencial apontar a enorme variedade de canais que foram trazidos pelas crianças. Isso já havia sido visto em pesquisas anteriores (ARAN-RAMSPOTT; FEDELE; TARRAGÓ, 2018; ARAÚJO, 2019; RIBEIRO, 2020) e é reforçado pelos achados desta. As 344 crianças participantes citaram ao todo 844 canais, sendo um total de 298 canais diferentes. Conforme será explorado nas entrevistas, isso indica que as crianças, por mais que assistam a vídeos de tipos semelhantes, têm suas preferências específicas em termos de quem gostam de acompanhar no YouTube.

$\mathrm{Na}$ lista do Quadro 13, estão agrupados os canais que foram citados por pelo menos 10:

Quadro 13 - Canais preferidos das crianças

\begin{tabular}{|c|c|c|c|}
\hline & Canais & \# de crianças & $\begin{array}{c}\text { \% de crianças que mar- } \\
\text { caram este canal }\end{array}$ \\
\hline 19 & Felipe Neto & 49 & $14 \%$ \\
\hline 2 o & Crescendo com Luluca & 36 & $10 \%$ \\
\hline 30 & Camila Loures & 28 & $8 \%$ \\
\hline $4^{\circ}$ & Nobru & 26 & $8 \%$ \\
\hline 5은 & Futparódia & 23 & $7 \%$ \\
\hline \multirow{2}{*}{60} & Rafa \& Luiz (Kids Fun) & 22 & $6 \%$ \\
\hline & Julia MineGirl & 22 & $6 \%$ \\
\hline \multirow{2}{*}{$7^{\circ}$} & Você Sabia & 20 & $6 \%$ \\
\hline & AuthenticGames & 20 & $6 \%$ \\
\hline
\end{tabular}




\begin{tabular}{|c|c|c|c|}
\hline $8^{\circ}$ & Gato Galactico & 18 & $5 \%$ \\
\hline \multirow{2}{*}{90} & Enaldinho & 17 & $5 \%$ \\
\hline & Planeta das Gêmeas & 17 & $5 \%$ \\
\hline $10^{\circ}$ & Flakes Power & 16 & $5 \%$ \\
\hline $11^{\circ}$ & LOUD & 15 & $4 \%$ \\
\hline $12^{\circ}$ & Luccas Neto - Luccas Toon & 13 & $4 \%$ \\
\hline \multirow{2}{*}{$13^{\circ}$} & Banheiristas & 12 & $3 \%$ \\
\hline & rezendeevil & 12 & $3 \%$ \\
\hline $14^{\circ}$ & Luluca Games & 10 & $3 \%$ \\
\hline
\end{tabular}

Fonte: elaborado pela autora

Apenas esses 18 canais foram citados por 10 ou mais crianças, sendo que mesmo o primeiro lugar, que é o canal do Felipe Neto, foi citado por menos de $15 \%$ dos participantes. Isso demonstra que o YouTube apresenta muitas opções de canais atrativos para as crianças, e que a preferência delas não está concentrada em poucos canais, mas sim bastante distribuída entre as opções.

Olhar a lista desta forma pode não significar muita coisa para quem não conhece os canais mencionados. Por isso, foi construído o Quadro 14 com um breve perfil de cada um desses canais, incluindo a quantidade de inscritos, de vídeos postados e a posição que ocupa no ranking de canais brasileiros por quantidade de inscritos. Essas informações foram extraídas do site Social Blade (2020), que fornece métricas sobre todos os canais da plataforma. Além disso, acrescentei também informações referentes à idade e ao gênero do youtuber protagonista desses canais e uma breve lista dos tipos de vídeos mais frequentes no canal, baseado nos vídeos postados durante o ano de 2020. O Quadro 14 agrupa essas informações:

Quadro 14 - Perfil dos canais preferidos das crianças

\begin{tabular}{|c|c|c|c|c|c|c|}
\hline & Canal & Youtuber & $\begin{array}{l}\text { Qnt. } \\
\text { Inscri- } \\
\text { tos }\end{array}$ & $\begin{array}{l}\text { Ranking } \\
\text { Brasi- } \\
\text { leiro }\end{array}$ & $\begin{array}{c}\text { Qnt. } \\
\text { Vídeos }\end{array}$ & Tipos de vídeo \\
\hline $1^{0}$ & Felipe Neto & $\begin{array}{c}\text { homem, } 32 \\
\text { anos }\end{array}$ & 40.3M & $3^{\circ}$ & 2,274 & $\begin{array}{c}\text { engraçados, } \\
\text { curiosidades e } \\
\text { gameplay }\end{array}$ \\
\hline $2^{0}$ & $\begin{array}{l}\text { Crescendo } \\
\text { com Luluca }\end{array}$ & $\begin{array}{c}\text { menina, } 11 \\
\text { anos }\end{array}$ & $9.13 \mathrm{M}$ & $83^{\circ}$ & 831 & $\begin{array}{l}\text { desafios, en- } \\
\text { graçados, } \\
\text { gameplay }\end{array}$ \\
\hline $3^{\circ}$ & Camila Loures & $\begin{array}{c}\text { mulher, } 25 \\
\text { anos }\end{array}$ & $12.5 \mathrm{M}$ & $44^{\circ}$ & 2,002 & $\begin{array}{c}\text { desafios, en- } \\
\text { graçados, ter- } \\
\text { ror }\end{array}$ \\
\hline $4^{\circ}$ & Nobru & $\begin{array}{c}\text { homem, } 19 \\
\text { anos }\end{array}$ & 11.2M & $53^{\circ}$ & 507 & gameplay \\
\hline
\end{tabular}




\begin{tabular}{|c|c|c|c|c|c|c|}
\hline $5^{\circ}$ & Futparódia & $\begin{array}{l}2 \text { homens, } \\
28 \text { e } 26 \\
\text { anos }\end{array}$ & $8.41 \mathrm{M}$ & $98^{\circ}$ & 430 & $\begin{array}{c}\text { paródias, fute- } \\
\text { bol }\end{array}$ \\
\hline \multirow[t]{2}{*}{$6^{\circ}$} & $\begin{array}{l}\text { Rafa \& Luiz } \\
\text { (Kids Fun) }\end{array}$ & $\begin{array}{l}\text { mulher e } \\
\text { homem, } 23 \\
\text { anos }\end{array}$ & $14.3 \mathrm{M}$ & $26^{\circ}$ & 1,247 & $\begin{array}{c}\text { desafios, en- } \\
\text { graçados, ter- } \\
\text { ror }\end{array}$ \\
\hline & Julia MineGirl & $\begin{array}{c}\text { menina, } 15 \\
\text { anos }\end{array}$ & $7.03 \mathrm{M}$ & $137^{\circ}$ & 1,952 & gameplay \\
\hline \multirow[t]{2}{*}{$7^{0}$} & Você Sabia & $\begin{array}{l}2 \text { homens, } \\
25 \text { e } 26 \\
\text { anos }\end{array}$ & $38 \mathrm{M}$ & $4^{\circ}$ & 1,148 & curiosidades \\
\hline & $\begin{array}{c}\text { AuthenticGa- } \\
\text { mes }\end{array}$ & $\begin{array}{l}\text { homem, } 24 \\
\text { anos }\end{array}$ & $19.5 \mathrm{M}$ & $14^{\circ}$ & 4,175 & gameplay \\
\hline $8^{\circ}$ & Gato Galactico & $\begin{array}{l}\text { homem, } 30 \\
\text { anos }\end{array}$ & $13.4 \mathrm{M}$ & $35^{\circ}$ & 1,417 & $\begin{array}{l}\text { gameplay, de- } \\
\text { safios e DIY }\end{array}$ \\
\hline \multirow{2}{*}{$9^{\circ}$} & Enaldinho & $\begin{array}{c}\text { homem, } 22 \\
\text { anos }\end{array}$ & $15.2 \mathrm{M}$ & $23^{\circ}$ & 1,219 & $\begin{array}{c}\text { desafios e trol- } \\
\text { lagens }\end{array}$ \\
\hline & $\begin{array}{l}\text { Planeta das } \\
\text { Gêmeas }\end{array}$ & $\begin{array}{c}2 \text { meninas, } \\
12 \text { anos }\end{array}$ & $13.8 \mathrm{M}$ & $30^{\circ}$ & 656 & $\begin{array}{c}\text { desafios, vlogs } \\
\text { e trollagens }\end{array}$ \\
\hline $10^{\circ}$ & Flakes Power & $\begin{array}{l}\text { homem, } 22 \\
\text { anos }\end{array}$ & $5.82 \mathrm{M}$ & $190^{\circ}$ & 1,196 & gameplay \\
\hline $11^{\circ}$ & LOUD & $\begin{array}{l}\text { equipe de } \\
12 \text { homens } \\
\text { e } 2 \text { mulhe- } \\
\text { res entre } 13 \\
\text { e } 26 \text { anos }\end{array}$ & $10.2 \mathrm{M}$ & $68^{\circ}$ & 622 & $\begin{array}{l}\text { desafios, en- } \\
\text { graçados e trol- } \\
\text { lagem }\end{array}$ \\
\hline $12^{\circ}$ & $\begin{array}{l}\text { Luccas Neto - } \\
\text { Luccas Toon }\end{array}$ & $\begin{array}{l}\text { homem, } 28 \\
\text { anos }\end{array}$ & $32.7 \mathrm{M}$ & $5^{\circ}$ & 1,158 & $\begin{array}{l}\text { teatrinho e en- } \\
\text { graçado }\end{array}$ \\
\hline \multirow[t]{2}{*}{$13^{\circ}$} & Banheiristas & $\begin{array}{l}2 \text { homens, } \\
\text { aproxima- } \\
\text { damente } 25 \\
\text { anos }\end{array}$ & $3.23 \mathrm{M}$ & $421^{\circ}$ & 741 & $\begin{array}{c}\text { futebol e desa- } \\
\text { fios }\end{array}$ \\
\hline & rezendeevil & $\begin{array}{l}\text { homem, } 24 \\
\text { anos }\end{array}$ & $28.3 \mathrm{M}$ & $7^{0}$ & 9,686 & $\begin{array}{c}\text { engraçados, } \\
\text { desafios e trol- } \\
\text { lagens }\end{array}$ \\
\hline $14^{\circ}$ & Luluca Games & $\begin{array}{l}\text { menina, } 11 \\
\text { anos }\end{array}$ & $3.3 \mathrm{M}$ & $409^{\circ}$ & 607 & gameplay \\
\hline
\end{tabular}

Fonte: elaborado pela autora a partir de dados do Social Blade (2020)

Podemos perceber que os tipos de vídeos produzidos por esses canais de fato correspondem às categorias mais citadas pelas crianças. Vale ressaltar que essa classificação dos vídeos dos tipos de vídeos presentes nos canais foi realizada por mim, com base na observação dos canais e conversas que eu tive com as crianças durante as entrevistas. Conforme já foi dito anteriormente, alguns tipos de vídeos podem se encaixar simultaneamente em diferentes categorias, como os desafios, trollagens, vídeos engraçados e até mesmo de terror, que muitas vezes consistem em uma grande brincadeira de aproximação-evitação (CORSARO, 2009a) realizada pelos youtubers.

Analisando o perfil dos youtubers desses canais, foi possível perceber que apenas 4 deles são youtubers mirins, todas meninas: Crescendo com Luluca, Julia 
Minegirl, Planeta das Gêmeas e Luluca Games - que é da mesma youtuber do "Crescendo com Luluca". Essa baixa presença de canais de youtubers mirins entre os preferidos dos participantes também foi constatada nas pesquisas de Ribeiro (2020) e de Araújo (2019), apontando possivelmente que as crianças dessa faixa etária possam preferir acompanhar youtubers mais velhos do que elas. Apesar de serem inúmeras as pesquisas sobre youtubers mirins, conforme apresentado no capítulo de revisão, é importante olharmos também para os conteúdos que os jovens e adultos estão produzindo e que estão sendo assistidos por crianças. Já o fato de todas serem meninas pode indicar uma possível falta de youtubers mirins meninos ou uma preferência mais forte ainda dos meninos por assistirem a conteúdos de youtubers mais velhos.

Os outros 14 canais são protagonizados por jovens e/ou adultos (com exceção da $L O U D$, que tem um único integrante de 11 anos). A média de idade aproximada desses youtubers é de 25 anos. Durante as entrevistas, que serão apresentadas na próxima seção, as crianças criaram o termo "jovens adultos" para se referirem aos youtubers dessa faixa etária, termo que será então utilizado para descrevê-los. Desses 14 jovens adultos, 11 são de youtubers homens, 1 de youtuber mulher e 2 são mistos. Na Espanha, Renés, Gozálvez e Berlanga (2020) também encontraram que os youtubers preferidos das crianças eram homens jovens adultos. É interessante observar então que, dentre os youtubers mirins, as meninas são as que mais fazem sucesso entre as crianças, mas quando são youtubers mais velhos, os homens predominam.

Felipe Neto, que tem o terceiro maior canal do Brasil, também ocupa o primeiro lugar nas outras duas pesquisas que realizaram levantamento com crianças dessa faixa etária (ARAÚJO, 2019; RIBEIRO, 2020). Ele e o irmão Luccas Neto construíram uma forte presença no YouTube durante a última década, envolvendose em diversas polêmicas ao longo dos anos e desagradando a muitos responsáveis (MATTOS, 2018; MALACARNE, 2020). Luccas Neto, que começou no YouTube em outro nicho e passou a fazer vídeos para crianças nos últimos anos, acabou "levando" seus seguidores a assistirem também ao canal do irmão - que, até então, não produzia conteúdos infantis. Com a chegada dos espectadores infantis, Felipe Neto passou a repensar sua produção de conteúdo, adequando suas temáticas e linguagem para o público mais jovem e sinalizando suas publicações que são destinadas para os mais velhos. Nos últimos anos, o youtuber vem admitindo seus erros do passado 
e assumindo uma nova postura, inclusive se engajando em discussões políticas e lutando a favor dos grupos minoritários (PINHEIRO, 2020).

Essa ressalva sobre o canal do Felipe Neto foi realizada por esse ter sido o primeiro canal da lista, com uma diferença considerável do segundo lugar, e por essas polêmicas terem sido tópicos frequentemente trazidos nas entrevistas com as crianças. Os demais canais preferidos terão suas temáticas aprofundadas de acordo com o que surgir nas entrevistas. A proposta aqui não é fazer uma análise dos canais com o olhar do adulto, mas sim entender os sentidos e a importância atribuída pelas próprias crianças. Serão apresentadas a seguir as diferenças dos canais favoritos por gênero, idade e perfil da escola, a fim de entendermos melhor se essas variáveis interferem nas preferências.

\section{Gênero}

Conforme apresentado, a variável de gênero parece ser associada com a preferência dos meninos por vídeos de jogos e de paródias e das meninas por vídeos de tutorial, vlog, slime brinquedos, DIY e maquiagem. Veremos então como essa preferência se dá em relação aos canais mais citados de cada grupo, como mostra o Quadro 15:

Quadro 15 - Canais preferidos por gênero

\begin{tabular}{|c|c|c|c|}
\hline \multicolumn{2}{|c|}{ Meninos } & \multicolumn{2}{|l|}{ Meninas } \\
\hline Canais & Frequência & Canais & Frequência \\
\hline Nobru & 24 & Crescendo com Luluca & 33 \\
\hline Felipe Neto & 22 & Felipe Neto & 27 \\
\hline Futparódia & 21 & Camila Loures & 24 \\
\hline AuthenticGames & 18 & Rafa \& Luiz (Kids Fun) & 20 \\
\hline Flakes Power & 16 & Julia MineGirl & 17 \\
\hline Você Sabia & 14 & Planeta das Gêmeas & \\
\hline Banheiristas & 12 & Luluca Games & 9 \\
\hline Enaldinho & & Gato Galactico & 8 \\
\hline LOUD & 11 & Luccas Neto & 7 \\
\hline Gato Galactico & 10 & Lucas Rangel & \\
\hline & & rezendeevil & \\
\hline
\end{tabular}

Fonte: elaborado pela autora

A partir do quadro, podemos perceber que as preferências de canais de meninos e meninas são bastante diferentes entre si. Apenas os canais do Felipe Neto e 
do Gato Galactico aparecem nas duas listas, sendo que o do Felipe Neto aparece em segundo lugar em ambas.

A lista dos meninos se configura em quatro canais de vídeos de temas mistos, como, por exemplo, vídeos engraçados, desafios, curiosidades, trollagens e gameplay (Felipe Neto, Enaldinho, LOUD e Gato Galactico), 3 canais que falam principalmente sobre jogos (Nobru, AuthenticGames e Flakes Power), 2 canais sobre futebol (Futparódia e Banheiristas), sendo o Futparódia exclusivo de músicas de paródias com a temática do esporte, e um canal exclusivo sobre curiosidades (Você Sabia).

Uma observação interessante é que a lista dos meninos é inteiramente composta por youtubers homens jovens adultos - com exceção de $L O U D$, que possui em sua equipe uma criança e duas meninas, mas que continua sendo prioritariamente composta por homens jovens adultos. Não há youtuber mirim ou youtuber mulher na lista. Essa preferência de os meninos assistirem a youtubers de mesmo gênero já havia sido encontrada na pesquisa de Ribeiro (2020), e pode se relacionar com a identificação de gênero, que é parte do processo de socialização das crianças ao longo da infância (CORSARO; DONNA, 1990).

Já a lista das meninas é um pouco mais variada nesse sentido, por apresentar cinco canais protagonizados por youtubers homens, 1 por uma youtuber mulher e 1 protagonizado por um homem e uma mulher. Além disso, apresenta também 4 canais de youtubers mirins meninas, sendo a Luluca protagonista de dois desses canais. Em relação às temáticas dos canais, a variedade dos tipos de canais é um pouco menor. Oito dos 11 canais da lista são mistos e têm prioritariamente vídeos engraçados, de desafios, vlogs e/ou jogos (Crescendo com Luluca, Felipe Neto, Camila Loures, Rafa \& Luiz, Planeta das Gêmeas, Gato Galactico, rezendeevil e Lucas Rangel). Dois outros canais são exclusivos de jogos (Julia MineGirl e Luluca Games), protagonizados por youtubers mirins meninas. O canal que mais difere da lista é o do Luccas Neto, que é composto por vídeos de teatrinhos/histórias fictícias, com atores contratados, roteiros etc.

Apesar de a lista de canais em si ser bastante diferente entre os grupos, vemos que as temáticas dos canais, principalmente desses que estou chamando de "canais mistos" não se diferenciam tanto. Como vimos, meninos e meninos gostam prioritariamente de vídeos engraçados, de desafios e trollagens - e nessa lista se acrescentam os vídeos de jogos, para os meninos. Então, a hipótese que podemos levantar 
é que, mesmo gostando de tipos de vídeos semelhantes, a grande diferença entre meninos e meninas está no youtuber de escolha; aquele que produz o conteúdo e a forma com que os vídeos são feitos. Durante a entrevista, conseguimos explorar melhor esse aspecto e entender como se dá a escolha e preferência por certos youtubers e não outros.

\section{$\underline{\text { Idade }}$}

Ressalto novamente que trabalhamos com faixa etária nesta pesquisa, mas separamos aqui as idades apenas para vermos se há alguma diferenciação entre as crianças de 8, 9 e 10 anos. Observando o Quadro 16, que mostra os canais preferidos por idade, vemos que a diferença entre os grupos parece se dar mais em função do youtuber em si do que em função dos tipos de vídeos do canal.

Quadro 16 - Canais preferidos por idade

\begin{tabular}{|c|c|c|c|c|c|}
\hline \\
\hline \multicolumn{2}{|c|}{8 anos } & \multicolumn{2}{|c|}{9 anos } & \multicolumn{2}{|c|}{10 anos } \\
\hline Canais & $\begin{array}{c}\text { Frequên- } \\
\text { cia }\end{array}$ & Canais & $\begin{array}{c}\text { Frequên- } \\
\text { cia }\end{array}$ & Canais & $\begin{array}{c}\text { Frequên- } \\
\text { cia }\end{array}$ \\
\hline $\begin{array}{l}\text { Crescendo } \\
\text { com Luluca }\end{array}$ & 18 & Felipe Neto & 16 & Felipe Neto & 22 \\
\hline Felipe Neto & \multirow{2}{*}{11} & $\begin{array}{l}\text { Crescendo } \\
\text { com Luluca }\end{array}$ & \multirow{2}{*}{13} & $\begin{array}{l}\text { Camila Lou- } \\
\text { res }\end{array}$ & 14 \\
\hline $\begin{array}{c}\text { Julia Mine- } \\
\text { Girl }\end{array}$ & & Você Sabia & & Nobru & 9 \\
\hline $\begin{array}{c}\text { Planeta } \\
\text { das Gê- } \\
\text { meas }\end{array}$ & 9 & Futparódia & \multirow[t]{2}{*}{11} & rezendeevil & 8 \\
\hline $\begin{array}{l}\text { Authenti- } \\
\text { cGames }\end{array}$ & 8 & Nobru & & $\begin{array}{c}\text { Flakes Po- } \\
\text { wer }\end{array}$ & \multirow{3}{*}{7} \\
\hline Futparódia & \multirow{3}{*}{7} & $\begin{array}{c}\text { Gato Ga- } \\
\text { lactico }\end{array}$ & 9 & $\begin{array}{c}\text { Rafa \& Luiz } \\
\text { (Kids Fun) }\end{array}$ & \\
\hline $\begin{array}{l}\text { Gato Ga- } \\
\text { lactico }\end{array}$ & & $\begin{array}{c}\text { Banheiris- } \\
\text { tas }\end{array}$ & \multirow[b]{2}{*}{8} & LOUD & \\
\hline $\begin{array}{l}\text { Rafa \& Luiz } \\
\text { (Kids Fun) }\end{array}$ & & $\begin{array}{l}\text { Camila } \\
\text { Loures }\end{array}$ & & $\begin{array}{c}\text { AuthenticGa- } \\
\text { mes }\end{array}$ & \multirow{4}{*}{6} \\
\hline \multirow[t]{2}{*}{$\begin{array}{l}\text { Camila } \\
\text { Loures }\end{array}$} & \multirow{3}{*}{6} & Enaldinho & \multirow{3}{*}{7} & $\begin{array}{c}\text { Julia Mine- } \\
\text { Girl }\end{array}$ & \\
\hline & & $\begin{array}{c}\text { Flakes Po- } \\
\text { wer }\end{array}$ & & $\begin{array}{c}\text { Lucas Ran- } \\
\text { gel }\end{array}$ & \\
\hline Nobru & & $\begin{array}{c}\text { Rafa \& Luiz } \\
\text { (Kids Fun) }\end{array}$ & & Now United & \\
\hline
\end{tabular}

São 4 canais que se repetem como preferidos para todas as idades, representados na tabela pelas células coloridas. O canal do Felipe Neto se apresenta como unânime entre as crianças. Já o canal da Camila Loures e do Nobru parece interessar 
cada vez mais às crianças conforme elas ficam mais velhas, o que pode ser observado a partir da subida de posição de ambos na lista. Outro canal que aparece para todas as idades é o de Rafa \& Luiz.

Vemos, então, que as crianças de 8 anos parecem gostar mais de canais de youtubers mirins do que as mais velhas, pois citam como favoritos 3 desses canaisCrescendo com Luluca, Julia MineGirl e Planeta das Gêmeas. Crescendo com Luluca se mantém como um dos preferidos para as crianças de 9 anos, assim como Julia MineGirl também aparece na lista dos 10 anos, apesar de estar em uma posição mais baixa na lista. Planeta das Gêmeas, por sua vez, não volta a aparecer nas listas de preferência das crianças de 9 e 10 anos. Esse achado aponta para a possibilidade de as crianças mais novas gostarem mais de acompanhar outras crianças online, enquanto as mais velhas talvez procurem youtubers jovens adultos.

\section{$\underline{\text { Perfil da escola }}$}

Conforme foi explicitado da seção anterior, a metodologia de produção de dados se deu de forma diferente com as crianças do Grupo 1 (escola que atende crianças de NSE menos favorecido) e do Grupo 2 (escolas que atendem NSE mais elevados). Apesar disso, ao analisar os resultados dos canais preferidos, essa diferença metodológica não parece ter afetado tanto essa questão quanto impactou na marcação dos tipos de vídeos preferidos. O quadro seguinte mostra a divisão dos 10 canais mais apontados como preferidos pelos grupos de crianças de perfis de escolas diferentes:

Quadro 17 - Canais preferidos por perfil da escola

\begin{tabular}{|c|c|c|c|}
\hline \multicolumn{2}{|l|}{ Grupo 1} & \multicolumn{2}{|l|}{ Grupo 2} \\
\hline Canais & Frequência & Canais & Frequência \\
\hline Felipe Neto & \multirow{3}{*}{26} & Felipe Neto & 23 \\
\hline Camila Loures & & Crescendo com Luluca & 12 \\
\hline Nobru & & Flakes Power & 10 \\
\hline Crescendo com Luluca & 24 & Futparódia & \multirow{3}{*}{8} \\
\hline Rafa \& Luiz (Kids Fun) & 18 & Gato Galactico & \\
\hline Futparódia & 15 & Julia Minegirl & \\
\hline LOUD & \multirow{3}{*}{14} & AuthenticGames & \multirow{3}{*}{6} \\
\hline Você Sabia & & Coisa de Nerd & \\
\hline AuthenticGames & & Jazzghost & \\
\hline
\end{tabular}




\begin{tabular}{|l|c|c|c|}
\hline Julia MineGirl & Você Sabia & \\
\hline
\end{tabular}

Fonte: elaborado pela autora

A primeira constatação que podemos fazer é que Felipe Neto realmente parece ser o preferido das crianças independente de gênero, idade e também de nível socioeconômico. Aqui, novamente, ele aparece no topo de ambas as listas, apesar de parecer empatado com Camila Loures e Nobru para as crianças do Grupo 1 e isolado em primeiro lugar para as crianças do Grupo 2.

Porém, se separamos os grupos por gênero, vemos que o Felipe Neto não está no primeiro lugar na lista nem das meninas nem dos meninos do Grupo 1, aparecendo aqui em primeiro apenas quando juntamos os dois gêneros. Já no Grupo 2, ele é o preferido das meninas e dos meninos, reforçando a hipótese de ele ser mais preferido entre as crianças de níveis socioeconômicos mais favorecidos. Araújo (2019) havia encontrado em sua pesquisa com 30 crianças que Felipe Neto era mais citado como preferido pelas crianças de escolas públicas do que de escolas particulares, resultado que não se assemelha a este, se considerarmos que crianças de escolas públicas geralmente vêm de NSE menos favorecidos. Contudo, precisamos de mais estudos de larga escala que considerem essa variável para podermos realizar tais comparações de forma mais robusta.

Além do canal do Felipe Neto, outros 5 canais aparecem em ambas as listas, em posições mais ou menos parecidas, indicando que os canais que as crianças têm como preferidos não parecem divergir tanto em nível socioeconômico. As maiores diferenças parecem estar nos canais da Camila Loures e do Nobru, que são preferidos das crianças do Grupo 1 e que têm 2 e 0 citações, respectivamente, pelas crianças do Grupo 2. Os canais Rafa \& Luiz e LOUD, da mesma forma, parecem interessar mais às crianças do Grupo 1, assim como Flakes Power, Gato Galactico, Coisa de Nerd e Jazzghost as crianças do Grupo 2.

Um aspecto importante, apesar de não ser o foco deste trabalho, é entender as especificidades de cada jogo de que as crianças gostam, algo que será mais bem explorado nas entrevistas. O FreeFire e o Fortnite, por exemplo, são jogos da categoria Battle Royal, em que o jogador tem um personagem em um mapa e precisa sobreviver se protegendo e eliminando os inimigos. Apesar de os dois serem gratuitos para smartphone, o FreeFire é um jogo bem mais leve, que roda melhor mesmo em celulares antigos, enquanto o Fortnite necessita de equipamentos 
melhores (KINAST, 2018; AZEVEDO, 2019). Então, essa é uma hipótese para explicar por que as crianças do Grupo 1 (NSE mais baixo) preferem o canal do Nobru, que fala de FreeFire, enquanto as do Grupo 2 (NSE mais alto) preferem o do Flakes Power, que traz gameplay de Fortnite.

Jazzghost e Julia MineGirl fazem vídeos sobre o popular jogo Minecraft, que é pago para todas as plataformas, mas bastante popular entre as crianças. Ressalto que Julia MineGirl aparece em posição mais alta para as crianças do Grupo 2, assim como Jazzghost, podendo indicar mais uma vez a facilidade de acesso aos jogos como um fator a ser levado em consideração.

Apesar de os vídeos de curiosidades terem aparecido como preferidos apenas para as crianças das escolas de NSE mais elevado, o canal Você Sabia, dedicado a apresentar fatos curiosos e interessantes, aparece aqui em ambas as listas. Por outro lado, o canal Coisa de Nerd não é nenhuma vez citado pelas crianças da escola de NSE menos favorecido, sendo um canal que também traz curiosidades, além de resenhas sobre tecnologia.

Algumas dessas constatações sobre a influência das variáveis dos diferentes perfis socioeconômico e gênero serão trazidas para debate ao longo da próxima seção, aprofundando a discussão e possibilitando melhor entendimento dos motivos de preferências entre as crianças. O objetivo a seguir não será de estabelecer comparações quantitativas, mas sim entender as nuances das subjetividades infantis considerando tanto as características universais da infância como as especificidades contextuais das crianças.

\section{2}

\section{A Plataforma do YouTube e as Crianças}

Daqui em diante, os resultados apresentados serão fruto das entrevistas individuais e coletivas que foram realizadas com as 30 crianças participantes desta etapa. É importante ressaltar que, apesar de trazer análises quantitativas, essa foi uma etapa essencialmente qualitativa, a partir de entrevistas semiestruturadas, - ou seja, alguns pontos podiam surgir em certas entrevistas e não se repetir em outras, ou serem abordados por mais de uma criança ao mesmo tempo. Por isso, os números 
trazidos aqui são apenas para ilustrar o quão presente aquele aspecto foi nas falas das crianças, e não para serem vistos como resumo da totalidade dos dados.

Nessa primeira parte, discutiremos, a partir das falas das crianças, os usos que as mesmas fazem do YouTube, a forma com que elas navegam na plataforma e as hipóteses que elas elaboram sobre o funcionamento da mesma.

\section{2 .1}

\section{O Uso e a Navegação das Crianças}

\section{YouTube ou Televisão?}

Ao início da conversa com as crianças, eu perguntava se elas preferiam assistir à televisão ou ao YouTube, imaginando que elas associariam televisão aos canais abertos e fechados disponíveis que passam desenhos animados ou outros programas. Algumas crianças, porém, relataram que "assistem YouTube na televisão", apontando justamente para um erro conceitual meu ao comparar uma tecnologia de distribuição (televisão) com uma plataforma que pode ser acessada por diferentes meios (YouTube). Burgess e Green (2018) apontam que ao longo dos anos o YouTube deixou de ser chamado de "site" para ser chamado de "plataforma", justamente por essa possibilidade de ser acessado em diversos dispositivos. A televisão (Smart $\mathrm{TV}^{12}$ ) atualmente é apontada pelas crianças como uma forma de acessar os diferentes serviços de streaming, como o próprio YouTube ou o Netflix. Sobre isso, Li relata:

Li (menina, 10 anos, renda alta): Televisão eu não assisto não, tipo, de ficar vendo os canais de TV ao vivo eu não vejo muito não. Eu vejo Netflix às vezes, vejo um filme ou outro, começo uma série ou outra...

A pesquisa mais atualizada sobre o uso da internet aponta que, só recentemente, as crianças e adolescentes de 9 a 17 anos estão acessando mais a internet via televisão do que via computador (CETIC.BR, 2020), o que pode ser explicado pela

\footnotetext{
12 A Smart TV (em português seria“televisão inteligente") começou a chegar ao Brasil por volta de 2011 e foi se popularizando ao longos dos anos. A Smart TV se configura pela possibilidade de integração com a internet, possibilitando assim o acesso a sites, aplicativos e plataformas como o YouTube.
} 
popularização das Smart TV. Segundo a pesquisa do CETIC, o uso do computador para acesso à internet vem caindo nos últimos anos e o uso da televisão vem subindo, alcançando $43 \%$ do uso das crianças no ano de 2018. Porém, o dispositivo mais utilizado continua sendo o celular, meio escolhido por $95 \%$ das crianças (CETIC.BR, 2020).

Apesar de termos visto alguns relatos sobre o uso da televisão como Smart $T V$, sendo usada para ver YouTube, a maioria das crianças mostrou entender televisão como o lugar de ver apenas canais abertos e fechados. Assim, 23 das 30 afirmaram preferir o YouTube à televisão. Os motivos de tal preferência giraram em torno, principalmente, da grande possibilidade de escolha que o YouTube permite, possibilitando que elas assistam ao de que gostam na hora em que desejam. Esse achado corrobora com a pesquisa realizada por Tomaz (2017). As falas abaixo exemplificam essa preferência:

Lulu (menina, 8 anos, renda alta): Ah, eu acho que tem mais opções pra a gente ver, e na televisão, tipo, "ai eu quero ver Detetives do Prédio Azul" não tem, aí não tem o que você quer, entendeu?

Davi (menino, 9 anos, renda baixa): Porque tem coisa mais divertida, você pode escolher o que você quer ver e o desenho vai...

João (menino, 9 anos, renda baixa): Vai passar uma coisa aleatória!

Essa questão da grande variedade de opções que o YouTube apresenta está bastante presente na fala das crianças, ainda somada à tendência do on demand, que representa a possibilidade de assistir àquilo que deseja sem ter que esperar o horário em que passa na televisão. Li, de 10 anos, traz para a discussão o fato de os youtubers lançarem vídeos com uma frequência muito alta, algo que não é comum em outras plataformas, como o Netflix:

Li (menina, 10 anos, renda alta): Ah, porque tem mais variedade, né? Ver série demora muito pra lançar, e YouTube não, tem canais que lançam um vídeo por dia!

Outras 5 crianças disseram gostar igualmente do YouTube e da televisão, argumentando que existem desenhos animados ou filmes que não há no YouTube, e por isso recorrem à TV para esses fins. Apenas 3 das 30 crianças expressaram preferir a televisão ao YouTube, sendo que dessas, uma optou pela televisão justamente pela possibilidade de ser Smart TV, possibilitando assistir a diferentes modalidades de programas, como vídeos, séries, desenhos etc. Bruno, menino de 9 anos 
de renda média, é a única criança que relata considerar que a televisão tem mais opções que o YouTube, devido a sua preferência por assistir aos desenhos animados.

\section{$\underline{\text { E as outras mídias? }}$}

Além da televisão, naturalmente outras mídias foram citadas pelas crianças ao longo da entrevista. Ao todo, foram 47 menções a outras mídias, sendo o Instagram, o WhatsApp e o TikTok os mais citados. Não havia nenhuma pergunta referente a esses aplicativos, mas era de se esperar que fossem citados, dada a cultura da convergência (JENKINS, 2015) em que vivemos. As crianças navegam entre essas mídias, e aquilo que está sendo visto no YouTube se reflete nas conversas com os amigos pelo WhatsApp, nas comparações com os conteúdos que consomem no Instagram e TikTok e até mesmo na possibilidade de descoberta de um novo youtuber pela novela a que assiste na televisão, como pode ser visto no exemplo a seguir:

Gabrielle (menina, 8 anos, renda baixa): Às vezes eu fico conversando com uma criança que eu tenho no WhatsApp, que ela é muito legal! Aí ela me pergunta quais os vídeos que eu gosto.

Luana (menina, 9 anos, renda baixa): $O$ da Lorena Queiroz ela já fez uma novela que eu vi, e aí eu descobri o canal dela assim.

Eu: E você já indicou algum vídeo pra eles?

(...)

Dezembro (menino, 9 anos, renda alta): Não, não, não. Só de um aplicativo que eu vejo! (...) TikTok.

Eu: Ah tá, do TikTok, entendi.

Dezembro: Você sabe o que é TikTok?

A fala de Dezembro ilustra a surpresa de muitas crianças ao saber que eu conheço os vídeos, canais e aplicativos a que eles se referem, mostrando como muitas vezes nós, adultos, somos vistos como distantes do universo lúdico das crianças. Essa questão será mais explorada quando abordarmos a mediação dos responsáveis em relação aos vídeos do YouTube. O foco aqui era mostrar como essas outras mídias perpassaram nossas conversas, assim como perpassam a rotina das crianças.

\section{A Conta do YouTube}


Para iniciar a discussão das especificidades do YouTube, retomaremos o seguinte impasse: as crianças, teoricamente, só poderiam ter uma conta na plataforma a partir dos 13 anos de idade, conforme já explicitado no capítulo 3. Ter uma conta é o que possibilita a ela interagir com os conteúdos, seja por meio de likes, comentários ou inscrição nos canais. Uma das perguntas que ainda não havia sido respondida pelas pesquisas é de que forma, então, as crianças estão usando a plataforma. As três hipóteses possíveis eram: ou elas usam sem interagir com os conteúdos, o que não parecia muito provável, ou criam contas próprias com idades falsas, ou usam contas de outras pessoas. Por isso, ao começo de cada entrevista, essa questão foi levantada para as crianças.

Das 30 participantes, 14 relatam ter contas próprias no YouTube e 14 dizem usar a conta dos responsáveis, sendo que 3 disseram que depende de qual dispositivo estão usando para acessar a plataforma. Apenas uma criança relatou acessar exclusivamente o YouTube Kids, que é a versão para crianças do YouTube, com menos recursos de interação, canais selecionados e maior monitoração dos responsáveis. As outras três crianças que acessam o YouTube Kids também utilizam a plataforma regular. Novamente, o que determina qual usar, é o dispositivo disponível:

João (menino, 9 anos, renda baixa): Eu assisto na minha televisão e no meu tablet, o YouTube normal, só que como eu tô com o celular e eu sou criança, o celular não deixa eu baixar o YouTube normal.

Vitória (menina, 9 anos, renda alta): No celular é o YouTube Kids, mas nos outros lugares é o normal.

Eu: Aham. Você vê por onde, sem ser celular?

Vitória: Computador e TV.

João e Vitória apontam aqui para algo interessante: utilizam o YouTube Kids no celular, dispositivo mais frequente para acesso à internet entre as crianças (CETIC.BR, 2020). João levanta a hipótese de que não pode colocar o YouTube "normal" no celular por ser criança. Provavelmente, a conta da Google cadastrada no celular está com a idade correta das crianças, e, por isso, impede que o aplicativo regular seja baixado.

Podemos perceber, então, que as crianças estão de fato acessando o YouTube com uma conta vinculada, seja com uma conta própria, e, consequentemente, uma 
idade falsa, seja com a conta de seus responsáveis. É interessante também a questão dessa fluidez de movimento entre os diferentes dispositivos, bastante mencionada pelas crianças ao longo das entrevistas.

Livingstone (2020) aponta para o grande dilema enfrentado atualmente em relação às crianças na internet: ou elas ficam invisíveis e não podemos de fato saber seus usos e protegê-las, ou seus dados ficam expostos e podem ser utilizados pelas grandes empresas. A criança que usa a conta com uma idade falsa ou com as informações de seus responsáveis não é vista pela plataforma como uma criança, o que dificulta que possamos pesquisar sobre a temática, entender suas preferências, protegê-la de possíveis perigos etc. Por outro lado, se permitimos que a criança tenha sua conta própria e seus dados expostos, ela estará sujeita a toda a indústria que visa lucro e que não está preocupada com seu bem-estar (LIVINGSTONE, 2020). Livingstone ainda comenta o fato de as crianças às vezes usarem contas e dispositivos de outros integrantes da família, o que faz com que os dados dos usuários se misturem, trazendo uma dificuldade a mais para tal dilema. Não há resposta simples para esses problemas complexos, que devem ser responsabilidade tanto das famílias e escolas quanto do Estado e das grandes empresas.

\section{Como as crianças acham os vídeos?}

Se as crianças muitas vezes utilizam contas de outras pessoas, como será que elas estão achando os conteúdos de que gostam? Conforme já explicitado no Capítulo 3, o YouTube funciona por meio de um algoritmo, que identifica quais tipos de vídeos e canais você mais assiste e assim consegue lhe recomendar mais conteúdos assim. E nesta pesquisa, essa parece ser a forma que as crianças mais descobrem vídeos e canais na plataforma. Foram 47 menções ao que chamamos de "personalização da experiência", que é justamente essa personalização que o YouTube realiza de acordo com aquilo que o usuário consome. Apenas 3 crianças não mencionaram essa personalização em algum momento da entrevista, todas as outras apontaram para isso uma ou mais vezes ao longo de suas falas.

Gabo (menino, 8 anos, renda baixa): Olha... isso eu não sei [como acha vídeos novos]! Eu abro o YouTube e já aparece um monte de vídeo.

Eu: Naquela página inicial?

Gabo: Aí o YouTube já tá acostumado, né? 
Dezembro (menino, 9 anos, renda alta): Não sei [como descobriu os canais], apareceu. Deve ser muito famoso, aí apareceu pra eu ver.

Isabela (menina, 9 anos, renda alta): É... Eu vejo o meu For You antes, aí se eu não gosto muito - For You é quando tem na televisão, tipo, que em geral você vê. Eu gostava muito de Adopt Me, né? Eu ainda gosto bastante, sou apaixonada. Aí eu pesquisei "Como ganhar dinheiro no Adopt Me". Aí eu comecei a ter muito, muito, muito vídeo disso, e eu comecei a descobrir vários canais. E depois, quando eu comecei a gostar de Tower of Hell, aí eu pesquisei de Tower of Hell, e na minha tela do For You apareceu um monte de coisa de Tower of Hell e aí eu fui vendo, e fui conhecendo os canais que eu mais gostei.

As crianças parecem entender bem a lógica de que os vídeos de que elas gostam, de alguma forma, aparecem para elas mais vezes, mesmo sem entenderem exatamente como isso acontece. A palavra "aparece" foi muito comum durante as entrevistas. Elas descobrem vídeos e canais novos pois esses aparecem para elas, geralmente na tela inicial ou na lateral da tela de exibição de um vídeo. Segundo Gabo, o YouTube já está "acostumado" a suas preferências. Dezembro, em sua fala, demonstra também saber que quando um canal é muito famoso, ele tem mais chance de aparecer para você - o que é verdade, considerando o algoritmo da plataforma. Já Isabela traz o que discutimos anteriormente, sobre a convergência das mídias ela chama a página inicial do YouTube de "For You", que na verdade é o nome da aba do TikTok onde aparecem vídeos recomendados para você, seguindo a mesma lógica da plataforma do YouTube. Ela demostra já entender muito bem como essa lógica funciona, e exemplifica isso a partir de dois exemplos dos vídeos sobre o jogo Roblox que aconteceram com ela.

Amanda, de 9 anos, traz para a discussão um outro aspecto: a possibilidade de pesquisa no YouTube.

Amanda (menina, 9 anos, renda alta): Não, acho que não [sente falta de vídeos no YouTube]. Porque... Quando eu vejo muito um vídeo, o YouTube, não sei o que acontece, mas ele fica me recomendando os vídeos pra eu ver de novo e de novo, então não tem nenhum vídeo que eu sinto falta não [...] Se sentir, é só pesquisar!

A pesquisa no campo superior da plataforma é uma ferramenta bastante utilizada pelas crianças, aparecendo na fala de 23 das 30 crianças. As crianças usam essa ferramenta para pesquisar assuntos novos e específicos, ou para digitar o nome dos canais que desejam conferir. 
Isabela (menina, 9 anos, renda alta): Eu comecei a jogar Roblox e eu pesquisei "como ganhar dinheiro", aí eu achei a Lolo kids, foi a primeira que eu achei. E aí eu comecei a ver vários vídeos dela. (...)

Eu: E aqueles vídeos recomendados que ficam do lado? Vocês também descobrem por ali?

Lulu (menina, 8 anos, renda alta): Eu não gosto muito de ficar ali passando, mas tipo, se for o primeiro mais legal eu já clico e assisto.

Ronaldo (menino, 10 anos, renda alta): Eu prefiro procurar os vídeos, não gosto de ver nos recomendados não.

Eu: Por que você não gosta?

Ronaldo: Porque às vezes aparece muita coisa errada ${ }^{13}$.

Ronaldo traz em sua fala uma preocupação frequente entre os adultos, de que as crianças tenham acesso, sem querer, a conteúdos inadequados para a idade. Essa questão dos conteúdos inapropriados será discutida mais à frente, mas aqui aparece o alerta trazido pela própria criança de que não necessariamente o YouTube indicará somente conteúdos bons para você - ainda mais quando essa conta é compartilhada com um adulto, por exemplo.

\section{2 .2}

\section{Como o YouTube funciona?}

Uma das grandes preocupações quando se discute a presença das crianças na internet é o fato de elas não entenderem o que tem por trás das câmeras, do funcionamento da plataforma do YouTube, dos bastidores dos vídeos. Bezerra (2018) encontra em sua pesquisa que as crianças entrevistadas por ela não têm noção do mercado por trás do YouTube nem da lógica de seu funcionamento, achando que os youtubers são pessoas comuns que gravam vídeos, não enxergando o quão lucrativa e trabalhosa pode ser essa profissão. Talvez por conta de o YouTube ter se popularizado ainda mais nos últimos anos, as crianças aqui entrevistadas, diferentemente dos achados da pesquisa de Bezerra, revelam ter bastante conhecimento sobre a lógica da plataforma e a profissão youtuber.

\section{A lógica do YouTube}

\footnotetext{
${ }^{13}$ Referindo-se a conteúdos inapropriados para a idade.
} 
Todas as vezes que as crianças levantaram hipóteses sobre o funcionamento do YouTube ou algum outro aspecto por trás das câmeras, elas foram sinalizadas com o código "lógica do YouTube". Esse código apareceu 33 vezes no total, sendo encontrado na fala de 28 das 30 crianças entrevistadas. As hipóteses das crianças giravam em torno principalmente da lógica de monetização da plataforma, do fato de os youtubers ganharem ou não dinheiro e do quão trabalhosa é essa profissão.

Quando perguntei se havia algum tipo de vídeo de que não gostavam no YouTube, Isadora e Daniel expressaram que, na verdade, o de que não gostam são os anúncios nos vídeos:

Isadora (menina, 10 anos, renda baixa): Eu só não gosto do comercial.

Eu: Ah, você não gosta do comercial, dos anúncios. E você, Daniel? Também não gosta ou gosta?

Daniel (menino, 8 anos, renda baixa): Eu fico bolado com os anúncios!

Eu: Fica bolado... Por que atrapalha o vídeo?

Isadora: É, porque fica emocionante, aí a gente vai ver algumas coisas e aí do nada aparece.

Eu: Entendi. E por que vocês acham que tem comercial nos vídeos?

Daniel: Patrocinadores?

Eu: Patrocinadores... Que que você acha, Isadora?

Isadora: Tipo, pra a gente ver e aí se a gente quiser fazer alguma coisa com isso, ou até comprar.

Daniel, com 8 anos, levanta a hipótese de que existem comerciais nos vídeos por conta de patrocinadores - o que corresponde bastante a o que realmente acontece. As empresas pagam por espaços para serem anunciadas nos vídeos. Isadora então complementa dizendo que o comercial é para nós, espectadores, para que possamos ver aquele produto ou serviço e decidir o que queremos fazer com aquela informação, incluindo a possibilidade de compra. Algumas crianças também relataram saber que é com as propagandas que os youtubers ganham dinheiro:

Bela (menina, 9 anos, renda baixa): [...] Mas tem uma youtuber que eu gosto também, não é das minhas preferidas, que ganha dinheiro. Assim, quanto mais... É que tem comerciais, quanto mais você vê o comercial até ofinal, mais ela vai ganhando dinheiro [...] ela falou em um vídeo.

[...]

Kaique (menino, 8 anos, renda baixa): Acho que a gente assiste bastante comercial, aí nisso eles ganham muito dinheiro!

Camila (menina, 8 anos, renda média): Eu vi um vídeo de um cara que ele tem 30 mil inscritos. Aí, ele falou que quem quiser saber como ele ganha dinheiro, quando o like ele é apertado, que tem gente que [...] faz propaganda de like, aparece anúncio... A gente tenta pular... Então, ele ganha dinheiro com isso. 
As crianças que me explicaram sobre as propagandas serem o que dá dinheiro no YouTube ressaltaram que aprenderam isso com os próprios youtubers, em vídeos em que comentaram sobre o assunto. Além dessas crianças que explicaram sobre as propagandas, outras hipóteses sobre a forma de os youtubers ganharem dinheiro foram levantadas. Ao todo, foram 32 menções ao longo das entrevistas de que os youtubers são ricos e ganham muito dinheiro com seus vídeos. Apenas 3 das 30 crianças não mencionaram isso em suas falas de forma específica. As crianças expressam saber que eles ganham muito dinheiro principalmente pelos bens materiais que eles mostram ter nos vídeos:

Miguel (menino, 8 anos, renda baixa): Eles moram numa mansão, tem piscina, eles têm uma moto, têm muito diamante no Free Fire.

Nina (menina, 8 anos, renda alta): Muito, com certeza!

Geremias (menino, 9 anos, renda alta): Muito! Por exemplo o Robin Hood, ele é rico! Nina: $O$ Gato Galactico ele tem duas mansões!

Julia (menina, 10 anos, renda alta): Não sei a Luluca, mas o Felipe Neto... Ganha! Eu: Você acha que ele ganha muito dinheiro? Ou pouco?

Julia: Muito! Porque ele era pobre antes do canal e agora ele tem uma mansão!

Essa questão de ver os youtubers como muito ricos será mais explorada na seção 6.3.3, mas já adianto aqui que esse é um dos pontos que as crianças, independentemente de suas rendas, mais trazem para diferenciá-los delas, não os vendo como semelhantes. Apesar de dizerem que os youtubers ganham muito dinheiro, as crianças sabem que isso não acontece da noite para o dia. Vinte e uma crianças apontam que youtubers iniciantes não ganham dinheiro, apenas aqueles que conseguem atingir um certo patamar. Novamente, as crianças levantam diversas hipóteses sobre o que é necessário para ganhar dinheiro no YouTube e de qual seria esse patamar. Em geral, essas hipóteses levam em consideração o número de inscritos do canal ou das visualizações do vídeo:

Eu: Você tá ganhando dinheiro já, com o YouTube?

Daniel (menino, 8 anos, renda baixa): Não, porque eu não tenho muitos inscritos. [...]

Eu: E com quantos inscritos vocês acham que começam a ganhar dinheiro?

Daniel: Mil, um milhão...

Isadora (menina, 10 anos, renda baixa): Cinco mil?

[...]

Daniel: Vai levar muitos anos pra você ganhar muito dinheiro, ganhar muito like e muitos inscritos. Vai demorar muitos anos! 
Camila (menina, 8 anos, renda média): Sim. Pra mim é 30 milhões.

Luiza (menina, 9 anos, renda média): 5 milhões, 6 milhões....

Eu: E como você acha que faz pra ganhar dinheiro no YouTube? Tem que ter o quê? Miguel (menino, 8 anos, renda baixa): Inscrito, seguidores, comentários, visualizações...

Eu: Quantos inscritos, mais ou menos, você acha que tem que ter pra ganhar dinheiro?

Miguel: Mil. Quer dizer, cem. É mil! Meu primo falou aqui que é mil.

Eu: Aham. E suas amigas que têm canal, elas ganham dinheiro?

$\mathrm{Li}$ (menina, 10 anos, renda alta): É canal pequeno, ainda não cresceu. Mas talvez um dia ganhe.

Eu: Você acha que tem que ter quantos inscritos o canal pra ganhar dinheiro, mais ou menos?

Li: Ah, eu perguntei isso pra minha mãe, e ela disse que tem que ter mais ou menos um milhão.

Amanda (menina, 9 anos, renda alta): É, tem que ter três milhões, mais de três milhões!

Conforme pudemos ver, as hipóteses das crianças sobre quantos inscritos ou visualizações são necessárias para ganhar dinheiro variam bastante. E, de fato, esse é um processo que não tem uma resposta tão simples. Em 2020, os requisitos mínimos para ativar a monetização em um canal no YouTube eram ter mais de 4 mil horas no total de exibição pública nos últimos 12 meses e mais de mil inscritos, além de ser necessário respeitar todas as regras da diretriz que determina quais conteúdos são adequados para monetização (YOUTUBE, 2020b).

Porém, poder ativar a monetização de um canal não significa começar a ganhar muito dinheiro, uma vez que você recebe através de visualizações e cliques dos anúncios que são exibidos em seus vídeos. O quanto você recebe por cada visualização varia de acordo com o seu CPM - Custo por Mil Visualizações - que, por sua vez, vai variar dependendo do seu conteúdo, de quanto as pessoas engajam, de quanto tempo passam assistindo aos seus vídeos etc. Ou seja, apesar de as crianças - assim como muitos adultos - não terem clareza dos algoritmos por trás da monetização do YouTube, suas suposições e conhecimentos sobre o quão demorado e difícil é esse processo estão corretas. A fala de Gabo, de 8 anos, representa bem essa dificuldade:

Gabo (menino, 8 anos, renda baixa): Nem sempre o melhor canal de futebol do mundo, ou o melhor canal de série do mundo, ou o melhor canal de basquete do mundo, ou o melhor canal de esporte, de todos os esportes do mundo - isso não quer dizer que vai ficar rico. Nem sempre a gente pode ser youtuber só por causa do dinheiro, porque às vezes a gente vai se dar mal, tipo assim: "Nosso vídeo bombou, a gente vai ganhar milhões!" Aí passava dois meses sem nada, três meses sem nada, 
cinco meses sem nada. Aí começaram a gravar mais vídeos, aí muito, muito mais vídeos e aí sim.

Nas falas das crianças, percebemos que esses conhecimentos sobre a lógica do YouTube são aprendidos tanto nos vídeos em si quanto no diálogo com seus familiares e seus pares. Conforme será apresentado mais à frente, algumas das crianças possuem canais na plataforma e muitas estão em contato com pares que possuem, então, muitas vezes, é a partir dessas vivências que elas elaboram seus conhecimentos e hipóteses. O momento da entrevista coletiva também pode ser considerado um momento de compartilhamento entre pares, como pode ser visto no diálogo abaixo entre Davi, que parece possuir um conhecimento mais denso da plataforma, e João, que se espanta ao saber o quão trabalhoso ser youtuber pode ser:

João (menino, 9 anos, renda baixa): Aí eu não sei [como ganha dinheiro]. Se eu fosse youtuber eu saberia!

Eu: Você sabe, Davi? Como ganha dinheiro?

João interrompe e fala: Eu acho que eu sei! É visualização, inscritos e like!

Eu: Que que Davi acha?

Davi (menino, 9 anos, renda baixa): Mesma coisa. Não, like não precisa e nem se inscrever, só visualização.

João: É verdade.

[...]

Eu: E vocês acham que precisa de quantas visualizações pra começar a ganhar dinheiro no vídeo?

Davi: É tipo umas... Um mil.

João: Umas... Um bilhão de visualizações, assim. Tem um vídeo que tem um bilhão de visualizações.

Eu: Aí você acha que só um vídeo de um bilhão que dá pra ganhar?

João: É, que dá pra ganhar dinheiro. Mil visualizações, assim, por aí, assim...

Eu: Então quando vocês criarem o canal de vocês, se vocês criarem, só depois de um tempão que vocês vão conseguir ganhar dinheiro?

João fala rindo: Eu acho que eu nunca vou querer ter canal! Que eu vou ter que trabalhar pra caraca, não vai dar não...

Diferentemente dos achados de pesquisa de Bezerra (2018) e Dalethese (2017), as crianças aqui entrevistadas parecem ter bastante noção de que ser youtuber é trabalhoso. Vinte sete das trinta expressam essa opinião em algum momento da entrevista. Duas das crianças que respondem que ser youtuber não dá trabalho são crianças que têm canal na plataforma e que parecem levá-lo mais como uma brincadeira, um momento de lazer, e não como uma tarefa, assim como a maioria das crianças da pesquisa de Dalethese. Os motivos de as crianças acharem que ser youtuber dá trabalho giram em torno principalmente da dificuldade em gravar e 
editar os vídeos, além da demanda de tempo que isso exige, muitas vezes não compatível com a rotina de crianças:

Supergamer (menino, 9 anos, renda baixa): É porque você tem que precisar de câmera... Você tem que ser... Se você tiver dormindo, e precisar gravar vídeo, você vai ter que levantar só pra gravar vídeo?

Lulu (menina, 8 anos, renda alta): Não é fácil. Você vai ficar muito enrolado. Tipo, os seus trabalhos de casa... E ainda tem um canal! É porque o YouTube me diz que eu tenho que postar essas coisas, porque quando não tem vídeo, aí eu tenho que postar, aí eu tenho que editar rápido... Eé muito enrolativo, entendeu? Enrola muita gente.

Li (menina, 10 anos, renda alta): Dá [muito trabalho ser youtuber]! Eu demoraria muito, fazendo um vídeo por semana, porque eu também tenho outras coisas pra fazer da vida.

Davi (menino, 9 anos, renda baixa): Eu preciso crescer... Eu preciso me tornar adolescente [...] porque... primeiro porque eu não sei porquê, tipo... No Fortnite, você precisa ter mais de onze anos pra participar de um campeonato. [...] E segundamente é porque eu preciso beber energético.

Eu: Beber energético? Por quê?

Davi: Streamer trabalha o dia e a noite inteira.

João (menino, 9 anos, renda baixa): Editando vídeo... Vendo os comentários....

Eu: Então dá trabalho ser youtuber?

Davi e João: Dá, muito! Pra caramba!

Certamente, ser youtuber atualmente é uma profissão que dá trabalho como muitas outras, ainda mais considerando que quanto mais vídeos você posta na plataforma, teoricamente, mais dinheiro você ganha. E as crianças parecem saber que essa é uma profissão, que quem está ali do outro lado da câmera não simplesmente ligou e começou a gravar, mas sim que teve todo um trabalho de preparação e pós produção e que, acima de tudo, está ganhando dinheiro com o que faz. A consciência das crianças sobre a lógica do YouTube vista nessa pesquisa se assemelha aos achados de Duarte, Leite e Migliora (2007) em relação à televisão. As crianças na pesquisa das autoras expressaram bastante competência ao analisar a televisão e construíram críticas e opiniões ricas a seu respeito, justamente por estarem muito inseridas nesse universo, se tornando verdadeiras experts na temática (DUARTE; LEITE; MIGLIORA, 2007). Ao longo de todo este trabalho, veremos como as crianças de hoje também expressam ideias válidas e interessantes sobre a plataforma do YouTube. 


\section{3}

\section{O YouTube e as Culturas Infantis}

Nesta seção, apresentaremos os resultados dialogando mais especificamente com o referencial teórico da Sociologia da Infância, com foco nas Culturas Infantis. Veremos aqui se os conteúdos a que as crianças estão assistindo no YouTube e suas práticas na plataforma dialogam com os eixos estruturantes das culturas da infância. Pensando então na definição de culturas infantis como sendo a "capacidade das crianças em construírem de forma sistematizada modos de significação do mundo e de acção intencional, que são distintos dos modos adultos de significação e acção" (SARMENTO, 2003b, p. 3), discutiremos de que forma as crianças estão significando e agindo no YouTube.

Como foi apresentado no Capítulo 2, as culturas infantis consideram a riqueza das diversidades culturais, sociais e históricas que trazem especificidades às diferentes infâncias. Porém, ao mesmo tempo, Sarmento (2003b) e Corsaro e Donna (1990) argumentam existirem certos denominadores comuns que unem as infâncias independente de tais aspectos. Nessa perspectiva de características universais presentes no cotidiano das crianças, Sarmento (2003a) aponta quatro eixos estruturadores das culturas da infância, sendo eles: a interatividade, a ludicidade, a fantasia do real e a reiteração. Será que esses mesmos eixos estão presentes quando pensamos nas práticas das crianças no YouTube?

Visando responder a essa pergunta, após ter sido realizada a codificação de todas as entrevistas, os códigos criados a partir das falas das crianças foram agrupados dentro desses quatro eixos. Ao todo, 96 códigos se encaixaram em um dos eixos, sendo distribuídos da seguinte forma: 34 códigos no eixo ludicidade, 32 no eixo interatividade, 27 no eixo reiteração e 3 no eixo fantasia do real. Essa distribuição já indica que o eixo que menos pode ser identificado nas práticas das crianças foi o de fantasia do real, o que não quer dizer que ele não exista, mas sim que não parece ser tão potente quando discutimos o YouTube.

É importante ressaltar também que esses eixos conversam todo o tempo entre si, e que foram separados aqui apenas para podermos olhar cada um em suas especificidades. O conceito de reprodução interpretativa de Corsaro (1990) será a lente para que possamos olhar as práticas e falas das crianças, entendendo que elas não são esponjas que simplesmente absorvem e reproduzem aquilo que estão vendo, 
mas sim que apreendem criativamente tudo aquilo, construindo, assim suas culturas infantis.

A partir de agora, serão apresentados os aspectos que foram mais presentes nos eixos de ludicidade, interatividade e reiteração. Ao final, também haverá duas seções específicas para tratar do que as crianças não gostam no YouTube e da vontade (ou não) delas de serem youtubers.

\subsection{1}

\section{A Ludicidade}

O aspecto lúdico é um dos principais quando pensamos na relação das crianças com o YouTube. Assim como acontecia com a televisão (FUENZALIDA, 1996), a motivação das crianças para assistirem aos vídeos é se divertirem, rirem, se distraírem do cotidiano. O de que elas mais gostam, efetivamente, são os conteúdos que apresentam fortes aspectos lúdicos e humorísticos, independente de variáveis específicas de gênero e renda.

O YouTube, no entanto, se diferencia da televisão ao ofertar um leque de opções muito maior para as crianças, e, além disso, ao considerar suas motivações e interesses de forma mais direta. Os youtubers que produzem conteúdos precisam estar interessados - principalmente por motivos financeiros - no que faz sucesso entre as crianças. Aqui, então, a lógica de produção é menos o que os pais ou educadores querem para as crianças, mas o que elas querem - o que é um avanço, por um lado, mas que também precisa ser olhado com atenção.

Veremos nesta seção, então, quais são esses interesses das crianças participantes, como eles se aproximam das culturas lúdicas e de que forma elas significam os conteúdos a que assistem.

\section{$\underline{\text { A diversão e o humor }}$}

Ao buscar entender o motivo das crianças para gostarem tanto do YouTube e dos canais a que assistem, encontramos que a resposta é mais simples do que imaginávamos: as crianças se divertem - e muito - com tais conteúdos. Entrar na plataforma, navegar entre as inúmeras opções de canais, e escolher um vídeo para assistir se configura como um momento de lazer muito caro a elas. As crianças usaram 
muito as palavras "legal", "divertido" e "interessante" para descreverem para mim suas motivações para assistem aos vídeos.

Nina (menina, 8 anos, renda alta): Porque ele [Gato Galactico] faz vlog, ele vai num jogo novo, ele ensina coisa, ele faz a gente criativos, ele explica teorias, faz ciências... Muito legal!!!

João (menino, 9 anos, renda baixa): Assim, eu acho bem legal, assim, interessante [os canais que assiste] [...] Porque sempre... Porque me interessa, assim. Eu, tipo, eu vejo desenho, eu vou lá, tento copiar, às vezes fica ruim, às vezes fica bom, pinto, boto na minha pasta.

Bela (menina, 9 anos, renda baixa): Às vezes eu me divirto de vez em quando, tipo, eu tô meio pra baixo, aí eu vou ver e começo a rir de repente.

Esses achados corroboram com os resultados de uma ampla pesquisa realizada na Catalunha, na qual pré-adolescentes atribuíram aos youtubers certas funções sociais (ARAN-RAMSPOTT; FEDELE; TARRAGÓ, 2018). O entretenimento apareceu em primeiro lugar, seguido pelo interesse dos assuntos abordados. Ou seja, assim como aqui, as crianças e pré adolescentes parecem acompanhar os youtubers principalmente pelo fato de eles serem divertidos e discutirem temáticas de seu interesse. A fala de Gabo representa bem essa ideia:

Gabo (menino, 8 anos, renda baixa): É porque eu gosto muito de futebol, mas também é porque esses vídeos são muito engraçados.

Ele está explicando por que gosta especificamente de 3 canais de futebol: Vosso Canal, Desimpedidos e Ginga Street. Existem milhares de canais sobre futebol no YouTube a que Gabo poderia assistir, mas o que ele está apontando aqui é que o fato de os vídeos serem engraçados colabora para sua preferência.

O humor, como apontado por Gabo, também apareceu bastante na fala das crianças. Elas frequentemente descreveram tais conteúdos como engraçados, o que explica então esse tipo de vídeo ter aparecido no topo da lista no levantamento. A maioria dos tipos de vídeos pode apresentar aspectos engraçados, seja por conta da temática ou do youtuber em si. Um vídeo ensinando a passar de fase de um determinado jogo pode ser muito ou pouco atraente para uma criança, e um dos fatores que vai determinar isso é o quão divertido e engraçado é aquele vídeo e/ou youtuber. Satler e Carrijo (2019) vão apontar que o estereótipo de um youtuber segundo as crianças é justamente o de alguém extrovertido, que fala de uma forma próxima, jovem e que diverte o público. 
Lulu, no extrato abaixo, está me explicando o porquê de ela gostar mais dos vídeos de um determinado youtuber do que dos outros. Ela fica empolgada em descrever o quão engraçado e divertido o youtuber faz ser essa brincadeira no vídeo, por conta da forma como ele lida com o "monstro":

Lulu (menina, 8 anos, renda alta): Eu acho muito engraçado, porque eles correm, muita coisa muito engraçada, tem muitos, muitos, muitos monstros. Tem o Zap, eu não sei o nome... Então o único que é mais medroso é o Zap. O Zap apareceu e o Felipe Calixto não tem medo, ele vai sair correndo! Aí ele corre, o Zap. Mas os outros não.

Esse tipo de vídeo descrito por Lulu é bastante comum no YouTube, e será explorado melhor na seção seguinte, juntamente com outros vídeos com fortes aspectos lúdicos, como os de desafios e trollagens.

\section{Brincadeiras, Desafios e Trollagens}

Conforme apresentado no início do capítulo, os tipos de vídeos de que as crianças mais gostam são os engraçados, de desafios, trollagens e de jogos (principalmente os meninos). Todos esses envolvem o caráter lúdico de maneira muito forte. Já sabemos que as crianças gostam desses vídeos por eles serem divertidos e engraçados. Mas de que forma elas se apropriam daquilo que está sendo visto? Será que elas brincam daquilo que veem os youtubers brincando? Ou a diversão está no simples ato de ver? Sobre isso, Nina, de 8 anos, aponta:

Nina (menina, 8 anos, renda alta): Porque é engraçado às vezes! [vídeo de desafio] Geremias (menino, 9 anos, renda alta): Muitas vezes engraçado!

Nina: É divertido ver as pessoas fazendo coisas novas e tudo mais. E você pode aprender a fazer na sua casa!

O que Nina está apontando em sua fala é a possibilidade de observar, adquirir e construir a cultura lúdica a partir dos vídeos do YouTube. As crianças, assim como podem participar de jogos e brincadeiras com pares, também podem observar outras crianças brincando, seja no dia a dia ou em um desenho de televisão (BROUGÈRE, 1998). Brougère (1998) argumenta que essa experiência que está sendo vista não é transferida de forma passiva para o indivíduo, mas sim co-construtora nesse processo, a partir do momento em que a criança vai significando de diferentes formas o que está sendo visto e assim construindo novos sentidos. 
Um adulto, vendo os vídeos de desafios ou trollagens no YouTube pela primeira vez, pode não entender muito bem como aquilo se configuraria como uma brincadeira. Isso acontece justamente porque "dispor de uma cultura lúdica é dispor de um certo número de referências que permitem interpretar como jogo atividades que poderiam não ser vistas como tais por outras pessoas" (BROUGÈRE, 1998, p. 108). Já as crianças que têm contato cotidiano com tais vídeos entendem seus sentidos, regras e significados, se constituindo como parte da formação dessa cultura lúdica.

Entretanto, como vimos, as crianças parecem estar assistindo mais youtubers jovens adultos do que outras crianças. Então, de que forma essas negociações de sentidos são construídas? E, indo além: será que elas de fato brincam daquilo a que estão assistindo?

A resposta encontrada aqui é que depende. Ver um vídeo de desafio ou trollagem é por si só divertido e válido. Porém, as crianças expressaram um forte desejo de trazer para suas realidades aquelas brincadeiras vistas nos vídeos. Vinte e duas das trinta crianças entrevistadas relataram já ter realizado atividades lúdicas vistas nos vídeos em casa, sendo que dessas: 14 fizeram desafios, 14 fizeram trollagens, 2 construíram brinquedos e uma fez uma brincadeira vista no vídeo.

Em relação aos desafios, as crianças relatam os mais diversos tipos: desafios de perguntas e respostas, de colorir, de jogos, de estourar balões e achar prêmios, entre outros. Bruno, Vitória e Gabrielle dão exemplos de desafios que viram em vídeos e fizeram:

Bruno (menino, 9 anos, renda média): Tipo, a pessoa tem que provar a comida de três pratos que estão na mesa vendada.

[...]

Eu: E quem participou desse desafio com você?

Bruno: Meu pai, minha mãe e eu.

Vitória (menina, 9 anos, renda alta): Eu gosto de desafio! Tem um desafio, que é dos 10 segundos, a gente tem que tentar pensar, qual é a resposta [...] Um desafio de qual animal que eu era, aí eu fazia a pontuação, escolhia o que era mais parecido comigo e colocava a pontuação que aparecia.

Gabrielle (menina, 8 anos, renda baixa): Minha vó tem uma foto com várias coisas, várias letras, e tem como fazer com o corpo [as letras]. Aí esse desafio eu já gostei, aí eu fiz.

Os desafios relatados, assim como os dos vídeos, são na maior parte das vezes em grupos. As crianças, então, relatam fazer essas brincadeiras com os primos, 
irmãos, responsáveis e/ou amigos. Vale ressaltar que as entrevistas foram realizadas no período da pandemia, o que pode ter influenciado em um menor aparecimento das brincadeiras entre pares de amigos do colégio, por exemplo.

Ao perguntar para as crianças se já tinham realizado algum desafio logo após questionar se elas gostavam de assistir a esse tipo de vídeo no YouTube, imaginei que elas me relatariam ter feito ou não apenas desafios que viram em vídeos. $\mathrm{O}$ interessante foi que, mais uma vez, meu olhar adulto me impediu de prever que as crianças trariam de uma forma muito mais rica essa questão dos desafios. Conforme apontado por Corsaro (2009a), Sarmento (2003b) e Brougère (1998), as crianças não apenas reproduzem aquilo que está sendo visto, mas sim, reinterpretam dando novos sentidos e significados às práticas.

Dezembro (menino, 9 anos, renda alta): Já [fez desafio]! Mas não aqueles desafios de... Que tem que ficar achando objeto. Eu boto, eu pego um copo com água da torneira, aí eu boto sabão dentro aí eu fico botando alguns itens dentro, algumas folhas. Na última vez que eu fiz eu botei Lufital!

Eu: E você viu isso no YouTube? As pessoas fazendo isso?

Dezembro: Não, eu achei interessante fazer pra me distrair um pouco, não ficar tanto no celular.

A fala de Dezembro nos pode remeter à prática muito comum das crianças de fazer "misturinhas", como por exemplo misturar o resto das bebidas no restaurante para ver o que acontece, ou misturar várias cores de tinta para ver o resultado. Um tipo de desafio bastante popular no YouTube é o Smooth Challenge, que consiste exatamente em misturar ingredientes diferentes em um copo. A parte do desafio é alguém ter que beber aquilo, e ganha quem conseguir beber mais. Esse é um exemplo que nos leva a pensar que a cultura lúdica que existe nos vídeos do YouTube não surgiu necessariamente lá por aqueles adultos que protagonizam os canais, mas sim a partir de elementos e brincadeiras que já faziam parte das brincadeiras infantis há anos - e talvez aí que more o segredo para tanto sucesso.

Outra brincadeira muito comum nos vídeos é a que Lulu relatou na seção anterior, que consiste em uma pessoa fantasiada de monstro perseguindo as outras, que devem fugir para não ser pegas e desvendar o mistério de quem é o monstro fantasiado. Essa é uma clássica brincadeira de aproximação-evitação, que é considerada universal nas culturas infantis (CORSARO, 2009a). Quando eu pergunto para as crianças se elas classificam esse tipo de vídeos como de terror, elas dizem que não, que é um mistério de brincadeira, que é divertido e engraçado. 
Sophia (menina, 10 anos, renda baixa): Do Planeta da Gêmeas, porque elas... É um vídeo tipo assim, dos dois homens que entram na casa dela [...] elas ficam morrendo de medo!

[...]

Eu: Ah, tá. Mas aí não é terror, é só mistério?

Sophia: Não, não é terror!

Lulu (menina, 8 anos, renda alta): Eu vejo muito no Kids Fun, sabe aqueles vídeos que a produção deles colocam monstro? Então, é muito legal! Aí, eles pedem comentário pra fazer uma estratégia e eu tenho muita estratégia. Então, eu coloco lá sempre que eles pedem.

Eu: Entendi. É aqueles vídeos que tem uma pessoa que você não sabe quem é, tem que ficar descobrindo quem é, tipo um monstro, né?

Lulu: Sim, enigma, mas o do Kids Fun é muito, muito diferente, tem que ficar fugindo, não pode deixar encostar neles. É mais um jogo, né? Mas na vida real!

Nas palavras de Lulu, esses vídeos são como jogos, mas na vida real. Se os desenhos animados com temáticas mais assustadoras ou de mistério e aventura já ajudavam as crianças a entenderem o mundo e lidarem com seus medos e inseguranças (FUENZALIDA, 2008), talvez os vídeos do YouTube, sendo ainda mais próximos de suas realidades, ajudem ainda mais.

Voltando a explorar possibilidades de desafios, um outro aspecto foi o fato de as crianças me relatarem experiência de já terem vivenciado desafios em seu diaa-dia, não necessariamente de forma intencional e planejada por elas. Geremias e Nina citam exemplos disso:

Nina (menina, 8 anos, renda alta):[...] Os únicos desafios que eu tinha mesmo era desafio do ovo de páscoa... Ou descobrir o brinquedo no Dia das Crianças!

Geremias (menino, 9 anos, renda alta): Desafio mesmo, só em Educação Física!

Esses relatos reforçam a ideia de como os vídeos no YouTube trazem alguns elementos que já eram presentes no cotidiano das crianças. As trollagens, por exemplo, se popularizaram com esse nome nos últimos anos, mas representam as clássicas pegadinhas ou pranks que existem nas culturas infantis desde sempre. O passar trote no telefone seria um exemplo de trollagem que provavelmente a maioria dos adultos de hoje fizeram na infância. Micaele, de 9 anos, traz um exemplo de situação também corriqueira e que ela significa como uma trollagem:

Micaele (menina, 9 anos, renda baixa): Eu, eu eu era bem pequena. Eu fingi, eu entrei dentro do meu guarda roupa e fingi que eu sumi, todo mundo ficou me procurando, aí foram no meu quarto, eu dei um susto em todo mundo! Eu abri a porta do guarda roupa e dei um susto em todo mundo!

Eu: Ah, entendi. E essa trollagem você viu em algum vídeo ou você fez da sua cabeça? 
Micaele: Eu fiz da minha cabeça.

O relato de Micaele é semelhante ao de várias outras crianças, que, com brilho nos olhos, me contam tais episódios que vivenciaram com suas famílias ou pares. Dezembro, menino de 9 anos de renda alta, relata rindo que gosta de trollagens pois adora zoar as pessoas, e que mais de uma vez já trocou o rótulo do condicionador pelo de shampoo em seu banheiro. As 14 crianças que já realizaram trollagens trazem principalmente as pegadinhas de enganação, com uso de objetos falsos, como uma aranha de mentira ou um ovo de plástico:

Luana (menina, 9 anos, renda baixa): Eu já fiz uma [trollagem]! [...] Mas não foi que eu vi na internet, foi uma que... Eu tenho um ovo de brinquedo, que ele parece muito com o real, e aí eu joguei no chão e meu avô pensou que era de verdade. Aí ele tentou pegar, só que quando ele viu no chão, tinha quebrado.

Júlia (menina, 10 anos, renda alta): Ah, eu já fiz uma trollagem em casa! [...] Eu tenho uns ovos de borracha. Aí, o meu pai tava na sala e eu pedi pra ele fazer um ovo mexido. Aí eu cheguei lá com os ovos e aí quando ele foi pegar um, eu "taquei" o ovo no chão! [ela e a mãe riem]

Eu: E você viu essa trollagem em um vídeo ou você inventou da sua cabeça? Júlia: Eu inventei.

Gabo (menino, 8 anos, renda baixa): Eu já fiz uma trollagem com meu primo, que, o Mateus, ele... Eu e o Mateus temos uma aranha falsa, né? Inclusive agora o Mateus acabou de me dar um susto.

Amanda (menina, 9 anos, renda alta): Eu já devo ter feito com a minha mãe, alguma vez [trollagem]. Ah! Lembrei de uma vez aqui quando eu ainda tava na minha creche. É... A gente foi pra uma festa, né, depois a gente voltou pra casa, aí tinha uma aranha - sabe aquelas aranhas de brinquedo, super realistas? Aí minha mãe... Aí eu fiz com a minha mãe, cê lembra, mãe?

Como vimos, os vídeos de trollagens são um dos preferidos das crianças, independente de perfil de escola, gênero e idade. Ao que parece, a possibilidade de fazer trollagens com objetos cotidianos e simples faz com que essa se torne uma brincadeira compartilhada entre as diferentes crianças. Outros exemplos de trollagens também seguem essa mesma lógica, podendo ser executados facilmente em casa, mas, trazem aqui um outro aspecto dessa prática: nem todo mundo leva a trollagem como uma brincadeira divertida.

Kaique (menino, 8 anos, renda baixa): Eu guardei um negócio quebrado e botei no celular da minha mãe, aí dei pra ela. Aí ela se assustou quando viu o celular quebrado.

$\mathrm{Eu}$ : Mas ela achou graça ou ficou brava com você?

Kaique: Ela ficou brava! 
Bela (menina, 9 anos, renda baixa): Eu peguei uma bolacha, e aí o recheio era branco, aí eu botei paste de dente, aí eu fui trollar minha tia. Ela ficou brava, que até se machuquei no pé.

Davi (menino, 9 anos, renda baixa): Minha irmã tá tão viciada em Fortnite que às vezes eu finjo que deleto o Fortnite. Eu crio uma pasta e eu deixo escondidinho.

Eu: E ela acha engraçado ou ela fica brava?

Davi: Fica brava!

João (menino, 9 anos, renda baixa) ri e fala: É claro né, o pessoal não gosta de trollagem!

João deixa claro que o "pessoal" não gosta de trollagem. Pode ser divertido para quem trolla, mas não necessariamente para quem é trollado. E esse é um dos motivos que impede algumas crianças de fazerem trollagens em suas casas, por acharem que seus responsáveis ficarão bravos. Após Amanda e sua mãe rirem relembrando de uma trollagem que vivenciaram juntas, Li, que também participava da entrevista relata em tom triste:

Li (menina, 10 anos, renda alta): A minha mãe não, ela fica brava...

Eu: Você já fez com a sua mãe, Li, e ela ficou brava?

Li: Não, nunca fiz, mas eu sei que ela vai ficar brava [...] Vai que ela fica brava e eu fico de castigo?

Essa não permissividade ou não abertura dos responsáveis é impeditiva também para as crianças realizarem alguns desafios que têm muita vontade.

Luiza (menina, 9 anos, renda média): Ela [Luluca] faz vários desafios, e eu não faço nenhum.

Eu: Entendi... E por que você não faz?

Luiza: É que me dá vontade de fazer, e eu vou saber que vou ficar encrencada.

Lulu (menina, 8 anos, renda alta): Eu já [quis fazer desafios], só que... Quase ninguém deixa, entendeu? Aí é muito difícil [...] Eu já perguntei. E não deixaram [...] Eu queria fazer aquele... Aquele, é parecido com o que o Ronaldo falou, que tem que ir estourando balão, né, só que vem um brinquedo! E se não vem brinquedo, vem... Qual o nome daquele troço de carnaval? [...] É, confeti! [...] Falaram que ia fazer muita sujeira...

A justificativa que os familiares de Lulu apresentam para não a deixarem fazer o desafio é uma fala bastante recorrente entre as crianças. A maioria das que nunca fizeram desafios em suas casas dizem que é pelo fato de dar trabalho demais, ser difícil, complicado. De fato, alguns desafios mostrados nos vídeos dos youtuber envolvem grandes produções e gasto de dinheiro, como o relatador por Nina: 
Nina (menina, 8 anos, renda alta): Eu já quis fazer um desafio, mas eu teria que ter uma casa especificamente, não poderia morar em um apartamento, tem que ser em uma casa ao ar livre, né. Porque montou percurso de corrida e tudo mais, fez tirolesa no telhado... Aí tem que ser casa.

As brincadeiras, desafios e trollagens então se apresentam de inúmeras formas e possibilidades através dos vídeos, podendo ir desde coisas simples até as mais elaboradas. O que estamos vendo, entretanto, é que as crianças em geral acham formas de trazer essas experiências para o seu cotidiano e se apropriam criativamente de ideias que são mostradas nos vídeos, não apenas as reproduzindo. E esse não é um processo linear, uma vez que, como já foi dito, os vídeos em si parecem dialogar com a cultura lúdica das crianças que existe muito antes da internet. Dessa forma, as práticas vão se ressignificando de acordo com o tempo e com as interações e interpretações das crianças, fazendo com que a plataforma do YouTube seja diferente para cada uma das crianças.

Sophia, menina de 10 anos de renda baixa, por exemplo, relata ter pesquisado no YouTube como ela poderia reproduzir um brinquedo chamado Squishy que é basicamente um objeto fofo para apertar. Ela viu no TikTok que existia uma versão de papel desse brinquedo, que poderia ser feita em casa, então correu para o YouTube para pesquisar como fazer. Essa apropriação feita por Sophia do YouTube representa uma alternativa aos vídeos que incentivam o consumismo infantil, pois, por mais que o desejo de ter o brinquedo original permanecesse, ela conseguiu aprender como fazer esse brinquedo de uma outra forma. E será que as crianças aprendem a fazer outras coisas assistindo aos vídeos do YouTube?

\section{"Eu aprendo a brincar!"}

A fala que dá título a esta seção foi dita por Dezembro, menino de 9 anos de renda alta. É uma fala que representa muito o que as crianças relatavam quando eu perguntava o que elas aprendiam com os vídeos do YouTube. Muitas crianças, de início, olhavam pra mim de forma confusa quando eu fazia essa pergunta, como se quisessem dizer “como assim, aprender com os vídeos?” As falas de Micaele, Isabela e Vitória trazem uma concepção do o que é aprender na visão delas:

Micaele (menina, 9 anos, renda média): Eu não aprendo nada, né? Porque o que a gente aprende mesmo é na escola! 
Isabela (menina, 9 anos, renda alta): Não! É só mesmo pra eu me distrair. Eu aprendo, sei lá, umas coisas que não precisa pra vida, sabe? Mas é só mesmo pra eu me divertir.

Eu: Aham. Mas tipo o que que você aprende que você acha que não é pra vida? Isabela fala rindo: A como jogar Tower of Hell! Você perde 3 horas da sua vida jogando, com raiva. Só que eu gosto de jogar! É uma distração, ainda mais nessa quarentena.

Júlia (menina, 10 anos, renda alta): Eu não acho que eu aprendo coisas de... Não muitas, eu aprendo algumas... Mas não muitas coisas novas sobre a vida, sabe?

Júlia e Isabela usam a mesma expressão para descreverem: não aprendem nada sobre coisas pra vida. Isabela aponta logo em seguida que aprende a jogar um jogo que gosta, que isso é uma distração para ela, que ela gosta disso - mas que isso não é para a vida. Micaele é mais direta ao dizer que as crianças aprendem mesmo é na escola, e não nos vídeos do YouTube. Na continuação da conversa, entretanto, ela relata ter aprendido a fazer slimes com os vídeos e também a se maquiar. Por que essas não seriam coisas válidas de se aprenderem? O aprendizado formal e escolar aqui já está sendo percebido pelas crianças como mais válido do que o saber cotidiano (SILVA, 2005).

Das 30 crianças entrevistadas, 17 falaram que não aprendem nada com os vídeos. Porém, ao ouvirem a opinião da outra criança participante, no caso de entrevistas coletivas, ou após eu desenvolver mais o tópico, a grande maioria dessas relataram que aprendem sim coisas com os vídeos. Era como se elas não considerassem as coisas que aprendem como válidas de serem relatadas, como se não fossem importantes como um aprendizado mais formal.

Após perceberem que tudo era válido como resposta aqui, as mais diversas coisas apareceram: aprender a jogar jogos (30 citações), aprender informações e curiosidades (11), aprender sobre os jogos (9), aprender a fazer maquiagem (6), aprender a desenhar (5), aprender a fazer slime (4), aprender a fazer/consertar coisas (3), aprender desafios e trollagens (3), aprender a dançar (1) - entre outros. Lembrando aqui que esse é o número total de citações ao longo da entrevista, então uma criança poderia repetir que aprende a jogar em momentos diferentes da conversa e isso está sendo contabilizado.

Aprender a jogar jogos foi o que as crianças mais citaram, sendo mencionado por 18 das 30 crianças de rendas familares, gêneros e idades diferentes. $O$ jogo mais citado pelas crianças foi Roblox, seguido por Minecraft, Fortnite e FreeFire. 
Roblox foi mais citado pelas meninas, enquanto Minecraft ficou bem equilibrado e Fortnite e FreeFire foram mais citados pelos meninos. Roblox e Minecraft são jogos onde você pode construir mundos, criar coisas, e jogar em diferentes modos dentro desses mundos - alguns modos mais criativos, de construção, outros mais de aventura, por exemplo. Já Fortnite e FreeFire se parecem mais com os jogos de tiro e/ou sobrevivência conhecidos, em que você vê seu personagem de fora ( $3^{\mathrm{a}}$ pessoa) e precisa vencer seus adversários com suas armas e equipamentos. Independente do jogo, o que as crianças mais trazem em suas falas é o quanto elas eram noobs ${ }^{14}$ antes nos jogos e os youtubers as ajudaram a serem melhores. O que é ser noob? Isabela e Nina explicam:

Isabela (menina, 9 anos, renda alta): Eu... No Roblox tem vários jogos e por exemplo, eu vejo um canal que tá jogando Tower of Hell, só joga Tower of Hell no Roblox. E aí, eu era muito noob, né? Noob é que eu era bem ruim. E aí eu fui vendo os vídeos e eu fui aprendendo melhor a jogar, fui aprendendo, aprendendo...

Nina (menina, 8 anos, renda alta): $O$ que eu mais assisto é quando ou tem gente jogando Roblox, ou tem gente construindo coisas, fazendo coisas criativas. Porque como eu sou noob nesse jogo, né, eu vejo como é que funciona.

O diálogo entre João e Davi mostra um pouco mais dessa cultura dos jogos, do que podem aprender com os vídeos e, acima de tudo, do compartilhamento dessas aprendizagens entre pares, algo que será mais explorado na próxima seção.

João (menino, 9 anos, renda baixa): Ah, eu acho... Assim né, não sei nem como dizer isso... Deixa eu ver aqui... Eu acho que eu não aprendo... Eu aprendo, um pouco. Tipo, no Fortnite, o cara disse que a melhor arma é a arma "snipe" (sniper)

Davi (menino, 9 anos, renda baixa) balança a cabeça e fala: Não é não.

Pedro ri e fala: Não?! Não é?

Davi: Não.

João: Qual é, então? Fala aí! Duvido que vocêfale!

Davi: A AUG é a melhor, porque ela tá dando dois de dano e na cabeça tá dando 52 de dano.

João fala rindo: Pelo amor de Deus! Assim você quer me lascar mesmo!

Os dois riem.

O YouTube, então, pode ser visto mais como um espaço de compartilhamento e troca de culturas lúdicas da infância, sem julgamento aqui do que seriam aprendizados ou jogos válidos. Buckingham (2010) argumenta que os jogos online podem

\footnotetext{
${ }^{14}$ Gíria utilizada em jogos que vem da expressão em inglês "newbie", que significa novato. Apesar de semelhantes, a palavra "noob" é muito mais utilizada na comunidade gamer, e tem um tom mais pejorativo, de que a pessoa não sabe jogar tal jogo.
} 
apresentar uma série de possibilidades de aprendizagem, se configurando como uma atividade de multiletramento para as crianças. E, se consideramos que jogos também são brincadeiras, Dezembro estava certo quando disse que o YouTube o ensina a brincar. Ademais, as crianças também relataram aprender a desenhar, a fazer slime, a fazer desafios e trollagens - atividades que também possuem forte carácter lúdico.

Para além dessas atividades, as crianças também relatam aprender informações e curiosidades, principalmente em canais como Você Sabia, Incrível e Felipe Neto:

Vitória (menina, 9 anos, renda alta): Sim [aprende coisas com os canais]. Principalmente no do Incrível e no do Você Sabia [...] No do Você Sabia eu aprendo sobre várias curiosidades sobre o mundo e no Incrível tem vídeo também sobre como você pode sobreviver em algum momento perigoso.

Isadora (menina, 10 anos, renda baixa): Eu só assisti um vídeo do Felipe Neto, que era sobre os tubarões daqui do nosso Rio de Janeiro, que tem muitos tubarões que a gente não sabe [...] Existe Tubarão Tigre, é... Que eles atacam o Tubarão Martelo.

Li (menina, 10 anos, renda alta): Eu aprendi muito com o Final Level e com o Felipe Neto. Felipe Neto sempre falou curiosidades sobre o mundo, tipo um lugar que uma pessoa nunca pisou, que o ser humano nunca pisou. Curiosidades sobre o mundo, tipo, que todo mundo acha que é verdade, mas é falso. E o Final Level me ensinou trabalho em equipe, que tipo, tem muito desafio tipo, acho que são 6 moradores de casa, aí faz 3 versus 3, ai eles trabalham em equipe pra fazerem tipo, desenho, de mímica.

O que Li traz, ao final de sua fala, é um tipo de aprendizagem diferente, que outras 4 crianças mencionaram. É uma aprendizagem de valores, hábitos, ou até mesmo, como aponta Gabo, de 8 anos, é aprender educação. Esse aspecto será mais explorado na seção sobre reiteração, onde falaremos sobre os youtubers serem ou não bons exemplos para as crianças.

Gabo (menino, 8 anos, renda baixa): Eu aprendo... A educação...

Eu: A educação?

João Pedro: Eu aprendi com o Vosso Canal que a gente, não consegue aquela coisa que a gente quis e aí a gente fala tipo "eu não tô nem aí". Sabe por quê?? Se eu falar... Tipo assim, se eu tentei ter um vídeo game e até agora a minha mãe não comprou pra mim, minha tia, meu avô... Ah, que saber? Eu não quero mais nada... [...] Aí tanto faz, não tô nem aí. Aí na hora que a mãe, o avô, a tia compra, a coisa que ele sempre quis, eles dão pra outra pessoa.

João (menino, 9 anos, renda baixa): Comigo eu aprendi que não pode arriscar a vida pra brincar, brincadeira boba. Não pode só porque você gosta de uma coisa, tem que obrigar o outro a fazer. E aprendi que você tem que viver a vida, você não pode ficar fazendo besteira, né. 
Apesar de algumas crianças terem mencionado esse aspecto da aprendizagem, ele não foi tão presente em suas falas, o que divergiu de quando as crianças apontavam a educação como uma das principais atribuições da televisão (DUARTE; LEITE; MIGLIORA, 2007). Em relação ao YouTube, parece ser muito claro para as crianças que seu objetivo principal é o lazer, o entretenimento. E que tudo bem ser "só" isso, pois o brincar e se divertir, é tão sério e importante para as crianças quanto o estudo ou trabalho para os adultos. (BROUGÈRE, 1998).

\section{3 .2}

\section{A Interatividade}

A interatividade é outro eixo importante das culturas infantis, se configurando pelo contato que as crianças têm com as várias realidades e instâncias de seu cotidiano, como por exemplo a família, a igreja, seus professores da escola, seus vizinhos e, principalmente, as outras crianças. Sarmento (2003a) aponta que é a partir dessas interações que as crianças aprendem sobre o mundo, com experiências e trocas que possibilitam sua apropriação e reinvenção.

Aqui, discutiremos as três interações que mais foram presentes nas falas das crianças: as interações com seus responsáveis, com os youtubers a que assistem e com seus os pares. A cultura de pares se configura como a principal marca das interações das crianças (SARMENTO, 2003b), permeando todas as outras relações que serão apresentadas. Conforme já foi apontado, a divisão feita neste trabalho é para facilitar a discussão e apresentação dos resultados, mas cada um dos aspectos apresentados conversa e se entrelaça com os outros, em um processo não linear, mas dialético.

\section{$\underline{\text { A mediacão dos responsáveis }}$}

A interação das crianças com seus responsáveis e a forma como eles mediam o uso do YouTube foi aspecto importante nas entrevistas. No dia a dia, ouvimos muita reclamação dos adultos sobre os youtubers, apontando como eles "deseducam" as crianças (MATTOS, 2018) ou até mesmo levantando campanhas contra eles (MALACARNE, 2020). Resta saber, como será que as crianças estão 
percebendo essas mediações feitas pelos seus responsáveis? O que elas pensam sobre as opiniões deles? Essas são algumas perguntas que buscamos responder com as entrevistas.

É importante ressaltar aqui que 20 das 30 crianças tinham responsáveis presentes no mesmo ambiente em algum momento da entrevista, sendo que desses, 6 estavam sentados ao lado da criança, prestando atenção e interferindo de forma mais direta nas respostas. Ou seja, as falas das crianças sobre os responsáveis algumas vezes eram ditas na frente deles, o que pode ter influenciado no quão confortáveis elas ficaram para expressar suas opiniões.

Quando falamos de mediação, Maidel e Vieira (2016) apontam que há 3 tipos mais comuns encontrados na literatura: a mediação ativa, onde há conversa, orientação e discussão com a criança sobre aquela atividade; a mediação restritiva, onde há a imposição de regras de utilização, tempo e/ou conteúdo e o uso acompanhado, que seria a presença do responsável no momento de utilização da criança.

Mas, antes de entender de fato a mediação, eu perguntei para as crianças se elas achavam que seus responsáveis conheciam os canais a que elas assistiam no YouTube. A grande maioria (25 crianças) expressaram que sim, que pelo menos um de seus responsáveis conhecia os canais favoritos:

Gabo (menino, 8 anos, renda baixa): Sim, até porque, como eu disse agora, sempre que eu vejo algum vídeo, dos vídeos que eu acabei de falar, né, a minha mãe vem: "João, que que você está vendo no celular?", aí eu falo assim: "Eu tô vendo aquele canal que eu gosto, mãe, o Vosso Canal", e ela fala "Ah bem" [...] Porque ela acha que o Vosso Canal é um bom canal pra ensinar a gente a jogar bola, a educação, essas coisas, sabe?

Luiza (menina, 9 anos, renda média): Eu falei pra ela que eu assisto. Ela falou que é bem legal.

Eu: Ela já assistiu com você?

Luiza: Sim, mas ela assistiu só um pouquinho do vídeo.

Lulu (menina, 8 anos, renda alta): Meu pai, ele conversa muito comigo. Quando eu tinha no celular, que meu pai comprou, meu pai tinha um aplicativo que dava pra ver tudo que eu assistia, e eu assisti as minhas coisas, meu pai falou: "Tá de parabéns, você não assistiu nada..." Entendeu? Mas assim, eu não assisto nada que não é pra minha idade, tipo, só quando meu pai... Tipo, se tem alguma coisa de terror eu falo: "Pai, posso assistir esse daqui?" Meu pai fala que não, eu não assisto. Eu fico de boa.

Gabo, Luiza e Lulu expressam situações em que seus responsáveis mediaram de uma forma mais ativa, conversando sobre os conteúdos a que as crianças estão assistindo. Lulu e Gabo apontam momentos de supervisão, ou até de mediação 
restritiva, no caso de Lulu, mas que depois geraram algum tipo de conversa sobre se aquilo era bom ou não para eles. Já Luiza relata que sua mãe sabe o canal a que ela assiste e também disse que é um bom canal, mas, quando foi assistir junto com a filha, assistiu só um pouquinho. Esse aspecto de não assistir junto foi bastante presente nas entrevistas. Apesar de os responsáveis conhecerem os canais, apenas 13 dessas crianças disseram que eles assistem aos vídeos junto com elas - o que nos possibilita pensar até que ponto eles de fato conhecem tais canais. Os motivos que levam os responsáveis a não assistirem aos vídeos e, consequentemente, não fazerem essa mediação de uso acompanhado, são variados, mas o que as crianças mais relatam é a falta de tempo e/ou interesse deles.

Daniel (menino, 8 anos, renda baixa): A minha mãe não curte não [assistir junto] [...] Tem outras coisas pra fazer, assim, estudar, porque ela tá na faculdade.

Isadora (menina, 10 anos, renda baixa): A minha mãe só assiste é... Escuta música de forró e de vez em quando ela vê algumas coisas de emagrecer, e outras coisas de ensinar comida.

Eu: E você conversa com a sua família sobre os vídeos que você assiste no YouTube? Dezembro (menino, 9 anos, renda alta): Não.

Eu: Não? Eles não conhecem os canais que você assiste?

Dezembro: Não, eles só mais gostam de ver TV, gostam de arrumar viagens pra ir, pra a gente, a nossa turma de escola.

Nove crianças ao todo relataram em algum momento da entrevista essa questão da não presença dos responsáveis, seja de forma mais natural ou demonstrando certo incômodo com isso. Das nove crianças, seis eram de renda alta, e duas expressaram seu incômodo em relação a se sentirem sozinhas, sem terem companhia para fazer desafios que gostariam de fazer, uma vez que seus responsáveis estão sempre ocupados.

Amanda (menina, 9 anos, renda alta): [...] Na minha casa não dá porque, tipo, minha mãe fica trabalhando assim, um tempinho, e depois fica cansada e não quer brincar. Aí meu pai... Meu pai passa o dia inteiro trabalhando, aí de noite ele quer ver jornal e não quer brincar. Não quer fazer desafio nenhum.

Li (menina, 10 anos, renda alta): É claro! [que já quis fazer desafio] O meu pai trabalha o dia inteiro, a minha mãe fica fazendo faxina o dia inteiro, fazendo coisa o dia inteiro... E no final do dia não quer porque tá cansada. Eu não tenho irmã, não tenho cachorro, não tenho ninguém, então eu não faço [...] Às vezes eu queria ter uma irmã. 
O que Li está expressando em sua fala parece ser a falta que sente dessa interação com outras pessoas, tão importante para as crianças, principalmente a interação entre pares. Novamente, lembro aqui que as entrevistas foram realizadas no momento da pandemia, o que pode ter colaborado para esse sentimento de solidão e afastamento de outras crianças com quem anteriormente conviviam. No entanto, o que as crianças trazem sobre não sentirem seus responsáveis tão presentes em seus usos do YouTube também foi encontrado por Becker (2017) em relação ao uso da internet para brincar.

Mas, parece que há um fator que vai além da "falta de tempo" quando as crianças trazem relatos de suas interações com os responsáveis. O que as crianças mais apontaram quando falavam de seus responsáveis foi o fato de eles reclamarem dos vídeos e/ou youtubers a que eles assistem. Ao todo, foram 35 menções a momentos em que os responsáveis reclamaram de algo relacionado ao YouTube, sendo que apenas 8 crianças não citaram nenhum momento assim ao longo da entrevista. Em alguns casos, os responsáveis apenas expressam sua opinião negativa, em outros, proíbem a criança de assistir aquele conteúdo, estabelecendo uma mediação do tipo restritiva. Quando o que acontece é os responsáveis apenas expressarem sua opinião, em geral, as crianças optam por continuar assistindo aos vídeos:

Luana (menina, 9 anos, renda baixa): Teve umas meninas que eu assisto que... Elas acham, boba. Mas ela não mandou eu parar de assistir [...] Diário da Carol. Hm... Manuzinha Star.

Eu: Aí essas... Foi sua mãe que falou? Falou que é boba?

Luana: Ela falou que são bobas, mas ela não mandou eu parar de assistir. [...] Eu: E aí você concordou que elas são bobas, parou de assistir, ou você acha que elas não são e continuou assistindo?

Luana: Não, eu continuei assistindo.

Dezembro (menino, 9 anos, renda alta): Sim, meu pai [reclamou de vídeo].

Eu: Por que que ele reclamou?

Dezembro: No ano passado eu via muito Luccas Neto, aí ele reclamou pra mim falando que ele faz muito vídeo de besteira.

Eu: Ah é? E você concordou?

Dezembro: Não, eu não concordei, eu continuo vendo, mas ele também não vê os vídeos que eu vejo, então...

Camila (menina, 8 anos, renda média): Minha mãe fala que todos são bobos.

Eu: Todos são bobos? Todos que vocês assistem?

Camila: É que ela não tem muito essa mania de jogar esse jogo, ela gosta de Mario, Sonic, da época dela.

$[\ldots]$ 
Camila: Minha mãe já falou que esse Luccas Neto é muito bobo, que essa Victória Mineblox é muito infantil. Mas eu ainda continuo assistindo porque é a minha vontade.

A última fala de Camila será tópico de discussão na seção 6.3.3, pois representa o que muitas crianças trouxeram durante toda a entrevista: a preferência individual delas, independente da opinião de responsáveis ou pares. Em alguns casos, entretanto, as crianças consideram as críticas dos responsáveis como válidas, e aí sim tendem a deixar aquele conteúdo de lado, como relata Isabela:

Isabela (menina, 9 anos, renda alta): Sim, às vezes. Tipo, minha mãe, quando eu via esses canais que a pessoa fala errado, minha mãe chegava e falava "nossa, filha, que horror, esse cara só fala errado!" Aí eu fui parando de ver, parando de ver, até que eи parei mesmo.

Alguns responsáveis que proíbem determinado conteúdo explicam o motivo para a criança, estabelecendo um diálogo e realizando assim uma mediação também ativa. Quando os responsáveis não dialogam com as crianças a ponto de elas entenderem os motivos, algumas só obedecem e deixam de ver aquele conteúdo, como foi o caso de Davi e Vitória:

Davi (menino, 9 anos, renda baixa): Fui proibido de assistir Felipe Neto...

Eu: Quem é que proibiu você de assistir Felipe Neto?

Davi: Minha mãe.

Eu: Que que ela falou?

Davi: Fala que é ruim pra saúde, que é um mau exemplo, sabe?

Eu: Ela explicou por que que ela acha isso?

Davi: Não sei...

Vitória (menina, 9 anos, renda alta): Acho que sim [responsáveis reclamaram de algum vídeo]. Sim. Era um canal de The Sims.

Eu: E por que eles não gostaram que você assistia?

Vitória: Eu não sei. Só que eles falaram que eu não podia.

[...]

Eu: E você gostava muito desse canal?

Vitória: Eu gostava, porque eu também jogo The Sims.

Por outro lado, algumas crianças dessa faixa etária, independente da renda familiar e do gênero, aparentam já sentirem uma necessidade de diálogo e explicação quando os responsáveis proíbem algo e elas consideram injusto. Li e Amanda comentam no trecho a seguir sobre como antes eram proibidas de assistir ao Felipe Neto e como conversaram sobre isso com suas mães ao perceberem que o youtuber havia mudado: 
Li (menina, 10 anos, renda alta): Felipe Neto, eu... Eu vi quando tava bem alta, o Felipe Neto, só que a minha mãe não deixava. Aí eu fiz uma coisa bem errada, que a minha amiga via escondido, aí eu via escondido com ela. Aí minha mãe descobriu! Aí eu falei com ela, aí um ano depois, mais ou menos, ela deixou. Mas, ela disse que se tivesse algo de errado não era pra eu ver mais. E não tinha! Aí hoje eu vejo até no almoço com ela.

[...]

Amanda (menina, 9 anos, renda alta): Aconteceu quase a mesma coisa comigo e com a minha mãe! Porque antes, antes, quando ele falava um monte de palavrão, minha mãe não deixava eu ver - e ela tava certa de não deixar eu ver. Aí, lá pra 2019, 2020 que ele parou de falar, minha mãe começou a deixar eu ver.

Eu: Aham. E aí como é que vocês descobriram que ele parou de falar? Sua mãe viu e te falou, ou você viu e falou "ih, não tá falando mais palavrão"?

Li e Amanda: Não!

Amanda: Eu fui vendo, eu vi que ele pintou o cabelo de novo de preto... Aí eu fui ver!

Li: E comecei a ver e tipo assim, não era umas coisas tipo 13+, não, era negócio tipo, bem normal "pessoas tendo um dia pior que o seu", "pessoas tendo o dia melhor que o seu", "pessoas no whatsapp". Aí tipo, eu falei pra minha mãe, "mãe, se tiver algo de errado eu saio" aí ela falou "tá, pode ver", aí eu vi.

[...]

Amanda: Até minha mãe vê às vezes quando ele tá no... É Roda Viva, que fala? Roda Viva... Que agora ele tá aparecendo em um monte de programa, sabe?

Essa questão do diálogo foi mais explorada quando eu elaborei uma situação hipotética e perguntei para as crianças o que elas fariam caso seus responsáveis as proibissem de assistir aos seus youtubers favoritos. Treze das 30 crianças disseram que obedeceriam seus responsáveis, deixando de assistir àquele canal de que gostam mesmo se não concordassem com o motivo. Gabo foi o mais enfático nessa questão, ao dizer que a palavra da mãe vem sempre primeiro:

Gabo (menino, 8 anos, renda baixa): Olha, se a minha mãe falar "Gabo, você não pode mais ver esses vídeos". Cara, eu vou parar de ver.

Eu: Mesmo se você achar que não tem nada de errado?

Gabo: Sim, porque palavra da mãe sempre vem primeiro né, é a palavra mais certa.

Apenas 4 crianças, sendo 3 meninos de renda alta e uma menina de renda baixa, disseram que não obedeceriam os seus responsáveis e continuariam assistindo aos canais. Anne relata que simplesmente entraria no quarto e veria escondido, enquanto os outros demonstraram que ficariam muito irritados com essa situação:

Dezembro (menino, 9 anos, renda alta): Eu ficaria $P-U-T-O$ [se responsável não deixasse mais assistir Enaldinho].

Eu: Mas que que você ia fazer? Você ia parar de ver? Você ia tentar conversar com ele?

Dezembro: Eu continuaria vendo, como eu continuo vendo o do Luccas Neto. 
Games BR (menino, 10 anos, renda alta): Eu ia assim "Ué, qual é? Por que eu não posso mais ver? Eu gosto de ver! Vocês vejam o que vocês querem, então eu vejo o que eu quero!" [...] Meus pais não estão nem aí pra games"

Geremias (menino, 9 anos, renda alta): Se fosse meus favoritos, favoritos, eu ia provavelmente gritar e continuar vendo. Mas se fosse um que eu não gostasse muito, eu ia deixar pra lá, eu ia parar de ver.

O que Geremias aponta sobre o canal favorito é trazido por diversas outras crianças que também expressam que ficariam muito tristes se não pudessem mais assistir aos seus canais prediletos. Esse é o fator que mais impactou para as outras 13 crianças, que, antes de decidirem se obedeceriam ou não a seus responsáveis, iriam tentar conversar com eles para entenderem qual é o problema com o canal a que assistem. Algumas crianças relataram que fariam com que seus responsáveis assistissem aos vídeos do canal para só então decidirem se realmente não era bom.

Isabela (menina, 9 anos, renda alta): Eu ia morrer! Eu não ia aguentar! [se algum responsável falasse que não pode mais assistir um canal que gosta muito]

[...]

Eu: Mas o que você acha que você ia tentar fazer?

Isabela: Eu ia tentar descobrir outros canais legais. [...] Eu ia tentar ver, eu ia ver mesmo se ele fazia alguma coisa errada e se ele fizesse mesmo, eu ia parar de ver. Mas assim, eu ia ver o canal com a minha mãe, pra gente tentar ver mesmo se ele faz alguma coisa errada.

Li (menina, 10 anos, renda alta): Eu ia pedir pra ela... Eu pediria pra ela o motivo e se esse motivo fosse coerente eu ia falar pra ela que eu ia parar de ver e ia ver outro. Só que eu ia ficar triste, porque é meu favorito...

Eu: E se você achasse que não era coerente?

Li: Se eu achasse que não era coerente, eu falaria: "Ó, mãe, vamos ver outro vídeo? Pra ver, foi só aquele vídeo, talvez". Aí eu pediria pra ela ver outro vídeo comigo, se tivesse, aí eu falei "tá, tudo bem, aí você me convenceu"

Júlia explica que essa é uma iniciativa feita também pelo youtuber Felipe Neto:

Júlia (menina, 10 anos, renda alta): Inclusive tem uma campanha do Felipe Neto, que ele pediu pros pais assistirem por uma semana o canal dele, e se eles gostarem eles se inscreverem. Se não, tudo bem. E aí agora tem uma \#mãescomfelipeneto.

Com esses relatos das crianças, conseguimos ver, mais uma vez, como elas significam e negociam as situações que vivenciam em seu cotidiano, sendo ativas em seus processos de decisão. Tendo explorado suas interações com os responsáveis, que muitas vezes estão mais distantes do que as crianças gostariam, vamos 
tentar entender melhor como se dá a relação das crianças com seus youtubers favoritos.

\section{$\underline{\text { A interacão com os youtubers }}$}

Chau (2010) e Burgess e Green (2018) apontam o YouTube como um grande espaço de cultura participativa, que se estabelece principalmente pelo sentimento de comunidade que é criado através da interação e participação dos espectadores. As interações mais comuns na plataforma são a inscrição nos canais, o like ou deslike, que pode ser deixado nos vídeos, e os comentários. Essas interações só podem ser realizadas por quem está logado no YouTube através de uma conta Google. Sabendo que muitas crianças usam as contas de seus responsáveis, será que elas estão interagindo com os youtubers a que assistem? Se sim, de que forma elas interagem? Como elas escolhem quando vão ou não interagir? Tentaremos responder a essas perguntas a seguir.

A inscrição nos canais é uma forma de interação menos direta com o youtuber. O "ser inscrito" significa que você "segue" aquele canal, que provavelmente deseja acompanhar mais vídeos daquele youtuber. Nesta pesquisa, 26 das 30 crianças relatam em algum momento da entrevista ser inscrita em canais. Apesar de quase todas as crianças se inscreverem, elas utilizam duas lógicas diferentes para tomar essa decisão. Algumas crianças são como Luiza, inscrevendo-se em todos os canais de que gostam:

Luiza (menina, 9 anos, renda média): Eu sou a que mais se inscreve em um canal, me inscrevo muito. Por exemplo, eu vi um vídeo, gostei, me inscrevi.

Outras, no entanto, como Gabo e Micaele, se inscrevem apenas naquele ou naqueles canais que são seus favoritos:

Gabo (menino, 8 anos, renda baixa): Nos outros não, eu sou mais chegado em si no Vosso Canal.

Micaele (menina, 9 anos, renda média): Eu sou inscrita... Só não sou inscrita em um! [...] Eu sou inscrita no da Bela e no do Rangel, no da Camila ainda não me inscrevi [...] porque o da Camila comecei a ver faz pouco tempo, ainda tô vendo os conteúdos... 
Essas diferenças de usos vão aparecer também nas interações por likes e comentários. As crianças têm lógicas únicas e válidas para explicarem seus motivos de gostarem ou não dos conteúdos, assim como de interagirem ou não com os youtubers. Os likes parecem ser a forma de interação mais comum entre as crianças, uma vez que 27 das 30 participantes relatam deixar likes em vídeos. Entretanto, mais uma vez, isso não significa que as crianças deem likes em todos os vídeos a que assistem. Poucas crianças distribuem likes "de graça", ou porque os youtubers pedem. A maioria tem seus critérios para tomar essa decisão de deixar ou não likes:

João (menino, 9 anos, renda baixa): Eu deixo like [...] Porque eu acho que os vídeo são bons, assim, bem trabalhados... [...] Quando que não gosto eu dou deslike!

Bela (menina, 9 anos, renda baixa): Tem alguns que eu até dou, mas tem outros que... É porque... Demora. Você ficar assistindo aí depois você dar like. Já tem um monte de gente dando like, pra quê você dá like também? Não é necessário.

Eu: E você Kaique, por que você não dá like?

Kaique (menino, 8 anos, renda baixa): Eles mandam dar like, eu não dou porque eu vou ver e já passou até da meta que eles pedem.

Eu: Vocês geralmente deixam like nos vídeos?

Li (menina, 10 anos, renda alta): Não, eu esqueço.

Amanda (menina, 9 anos, renda alta): Não [...] Porque, tipo...

Li: Já tem muito like mesmo!

Amanda: Não sei, porque a gente esquece. Porque pelo menos eu esqueço. Não faz muita diferença...

$\mathrm{Eu}$ : Você esquece. E Li?

Li: É tipo, tem uns vídeos, tipo... Nem pede pra dar like, mas tipo, que eu acho tão bem feito, tipo, um negócio tão bem feito, que eu dou like! Mereceu, o cara fez um negócio perfeito.

Amanda: Eu só dou like quando é uma coisa que eu não quero esquecer [Li fala "eu também"] aí eu dou like e no final do YouTube fica em uma parte de marcados com o like.

Amanda e Li estão mencionando na última fala delas ao fato de os vídeos marcados com like irem automaticamente para uma playlist específica que o YouTube cria. Assim, as meninas usam o like como uma possibilidade de salvarem aquele vídeo nessa pasta. Elas poderiam simplesmente colocar o vídeo na playlist que desejassem, sem precisar dar o like, entretanto, essa foi a forma de uso que encontraram e que parece funcionar para elas.

Tanto Li quanto João apontam que às vezes o vídeo é tão bom que merece o like deles. Apesar de alguns merecerem o like, o que as crianças também apontam nessas falas é a necessidade em si de deixar o like. Para que deixar like se tantas outras pessoas já deixam? Como Kaique ressalta, às vezes ele vai assistir ao vídeo 
e o vídeo já até passou da meta de likes estipulada pelo youtuber. Essa é uma prática comum entre os produtores de conteúdos, que estabelecem metas a serem alcançadas em seus vídeos (TOMAZ, 2017), às vezes oferecendo conteúdos desejados pelas crianças caso elas consigam ultrapassá-la. Satler e Carrijo (2019) perceberam que as crianças se sentiam mais estimuladas a interagir quando havia metas de comentários, por exemplo, o que não parece ser o caso nesta pesquisa.

É na seção de comentários que as crianças têm maior possibilidade de interagirem com os youtubers e entre si. Um comentário em um vídeo é composto pelo nome e foto da pessoa que deixou o comentário, pela data do comentário e pelos botões de like, deslike e resposta - assim, é possível interagir também com um comentário específico. Dezoito crianças relatam deixar ou já terem deixado comentários nos vídeos, mas nenhuma delas diz que essa é uma prática frequente. Não pareceu haver diferença de gênero nessa prática, diferentemente da pesquisa de Ribeiro (2020), onde as meninas comentavam mais. Quatro crianças disseram deixar comentário quando o youtuber pede, como, por exemplo, Kaique e Lulu:

\footnotetext{
Kaique (menino, 8 anos, renda baixa): Porque eles pediram pra... Tipo assim, pra mim torcer pro time, aí eu fui lá e botei lá no comentário que time que eu tava torcendo.
}

Lulu (menina, 8 anos, renda alta): Eu vejo muito no Kids Fun, sabe aqueles vídeos que a produção deles colocam monstro? Então, é muito legal. Aí, eles pedem comentário pra fazer uma estratégia e eu tenho muita estratégia. Então, eu coloco lá sempre que eles pedem!

Esses são exemplos de vezes em que as crianças usaram os comentários para se expressarem, para darem sua opinião sobre algo que o youtuber pediu, sem esperar que ele interaja ou responda de volta. Apenas duas crianças relataram deixar comentários visando a resposta dos youtubers. Em geral, elas sabem que são muitos comentários deixados, e que eles não irão responder aos delas. Apesar disso, três crianças relataram já terem recebido respostas de youtubers, e como podemos ver nas falas abaixo, suas reações foram bem diferentes:

Eu: Eles já te responderam alguma vez?

Anne (menina, 9 anos, renda baixa): Só uma.

Eu: Só uma? Quem respondeu?

Anne: Os Irmãos Berti.

Eu: $O$ que que você tinha comentado?

Anne: Ah eu mandei só oi.

Eu: Você ficou feliz que eles te responderam? Ou você nem ligou?

Anne: Eu nem liguei. 
Diego (menino, 10 anos, renda alta): Geralmente era na época do Minecraft [...] Se dá pra fazer isso na versão que eu estava.

[...]

$\mathrm{Eu}$ : E alguém te respondia?

Diego: Sim.

Eu: $O$ youtuber ou outra pessoa?

Diego: Geralmente primeiro era o youtuber e depois outras pessoas.

Eu: E alguma vez os youtubers responderam vocês?

João (menino, 9 anos, renda baixa): Não, não... Nunca.

Davi (menino, 9 anos, renda baixa): Eu já fui respondido umas três ou duas.

João fala chocado: Ele já te respondeu?!

Davi: Já.

[...]

Eu: E você ficou feliz que ele te respondeu? Ou você nem ligou?

Davi: Sim!

João: Eu ia começar a gritar muito feliz!

A empolgação de João ao imaginar um youtuber lhe respondendo não foi tão comum entre as crianças da pesquisa, que, conforme será explorado na próxima seção, não parecem atribuir um status de ídolo aos youtubers preferidos. Apesar disso, outras 3 crianças também expressaram que gostariam de ter mais interação com seus youtubers preferidos, para que eles pudessem conversar e/ou responder às perguntas dos seguidores.

Ainda em relação aos comentários, Isabela trouxe outros pontos importantes, sendo o primeiro a interação com outras pessoas na plataforma:

Isabela (menina, 9 anos, renda alta): Depende, porque às vezes, eu tô vendo na televisão, e na televisão não tem como deixar like nem comentário. Mas assim, eu deixo quando eu tô vendo no tablet ou, por exemplo, elas perguntam "Ah gente, tem como fazer isso no Adopt Me?" e aí eu respondo nos comentários etc.

Conforme apontado por Ribeiro (2020), as crianças em geral não veem o YouTube como um lugar para fazerem novos amigos. A interação mais direta que elas podem ter com outras crianças espectadoras é, como Isabela falou, respondendo e interagindo pelos comentários dos vídeos. Outro aspecto da fala de Isabela é a impossibilidade de interação quando se usa a televisão para assistir aos vídeos. Isso é apontado por outras duas crianças, sendo esse o maior impedimento delas para interagirem. Isso mostra como o YouTube é uma plataforma, que pode ser acessada por diferentes meios com diferentes possibilidades de usos (BURGESS; GREEN, 2018). 
Finalizando esse tópico, vemos novamente como as crianças utilizam a plataforma de formas diferentes, adaptando as funcionalidades oferecidas às suas possibilidades e interesses individuais. A interação ou não com os youtubers assume diferentes significados para as crianças. Camila, por exemplo, explica sua não-interação a partir de uma lógica muito única:

Camila (menina, 8 anos, renda média): Eu interajo com nada, eu só vejo o vídeo e saio, vejo outro... Eu não sou aquela de... é muito do comentário, não. Porque depois, ele fica ganhando view com os likes das pessoas. Eu não sou muito desse costume, tipo, eu ver esse vídeo, é ver por mim mesma, porque é maneiro e é legal.

Eu: Ah, então você acha que às vezes eles ficam pedindo pra dar like, essas coisas, só pra ganhar view?

Camila: É. Eu não sou tanto também de deixar comentário não, eu já falo no cérebro mesmo, vou mandar essa carta aqui por telepatia!

A riqueza das falas das crianças será explorada agora em relação a como elas se relacionam e trocam com seus pares.

\section{$\underline{\text { A Cultura de Pares }}$}

A cultura de pares é um conceito chave para pensarmos a infância, que permeou todas as entrevistas realizadas e aqui será discutida de forma mais aprofundada. Segundo Corsaro (1990), a cultura de pares pode ser definida como "um conjunto de atividades ou rotinas, artefatos, valores e preocupações que as crianças produzem e partilham na interação com os seus pares.” (CORSARO; DONNA, 1990, p. 197). Ao todo, foram 117 citações das crianças que envolviam situações de trocas entre pares, seja entre a criança entrevistada e seus amigos, ou entre os próprios participantes da entrevista. Existiam algumas perguntas no roteiro de entrevistas que abordavam diretamente essas trocas, mas diversas vezes as crianças traziam situações que envolviam pares de maneira espontânea.

Como já mencionado anteriormente, duas crianças que fizeram entrevistas juntas eram primos, e outras duas são da mesma turma da escola. Todas as outras que fizeram entrevistas coletivas estavam se conhecendo ali, naquele momento, e foi muito interessante perceber como as interações se davam entre elas. Algumas mais tímidas, sem interagir tanto, e outras, como Davi e João que protagonizaram momentos em que parecia que eles já eram amigos há anos: 
João (menino, 9 anos, renda baixa): Porque sempre... Porque me interessa, assim. Eu, tipo, eu vejo desenho, eu vou lá, tento copiar, às vezes fica ruim, às vezes fica bom, pinto, boto na minha pasta.

Davi (menino, 9 anos, renda baixa): Todos os desenhos que você pinta é bom!

João: Não, peraí que vou te mostrar um, pra você ver!

Davi fala com voz de narrador: Iremos ver a procedência dessa pintura.

[João mostra desenho do Naruto]

Eu: Ah, ficou lindo! Arrasou!

Davi fala batendo palma: Oh my god! Melhor do que eu!

As crianças em geral falam de seus pares com muito carinho, trazendo situações que vivenciaram juntos e expressando como a amizade entre eles é valiosa:

Camila (menina, 8 anos, renda média): Eu fico falando com ela [sobre os vídeos], porque ela é a única que entende, porque quando a gente briga, a gente volta em um minuto a ser amiga.

Eu: Aí com ela você conversa sobre os vídeos?

Luiza (menina, 9 anos, renda média): Eu sou a mesma coisa com a minha prima [...] A gente tá brigando, aí passa cinco minutos e a gente tá se amando de novo, aí passa cinco minutos a gente tá brigando de novo.

Eu: Isadora conversa com quem? Com as amigas?

Isadora (menina, 10 anos, renda baixa) fala em tom triste: Sim, da minha escola. Mas teve uma delas que era minha preferida que viajou.

$\mathrm{Eu}:$ Você já teve vontade de fazer [trollagem]?

Diego (menino, 10 anos, renda alta): Não.

Eu: Por que não?

Diego: Bem, amigo eu não gosto que se ferre, então eu não faço [...] Amigo eu não gosto que eu veja ele se prejudicando, essas coisas. Por isso que eu não faço.

Além de citar amigos de escola e de outros espaços, as crianças também trazem frequentemente a figura de seus primos, principalmente os primos um pouco mais velhos. Os primos indicam canais, assistem juntos, conversam sobre os youtubers de que gostam. Novamente, no contexto da quarentena, pode ser que as figuras familiares tenham ficado ainda mais em evidência, uma vez que as crianças não estavam encontrando seus amigos de escola. Gabo aponta como esse contato mudou durante a quarentena, em um relato que mostra a importância da tecnologia para a interação à distância entre pares (BECKER, 2017):

Gabo (menino, 8 anos, renda baixa): Eu não costumo falar com os meus amigos pelo telefone, e sim mais... só às vezes, né? Mas a maioria das vezes a gente sai e se reúne, só que agora eu tô falando um pouco mais com eles... Porque... Por causa da quarentena, né? 
Em relação aos vídeos do YouTube, a troca mais frequente entre pares foi a recomendação de vídeos e canais, sendo citada 41 vezes ao longo das entrevistas. É comum haver entre as crianças indicações de vídeos que gostaram, para que a outra possa conhecer, o que pode ser visto como uma forte prática de construção e compartilhamento das culturas infantis.

João (menino, 9 anos, renda baixa): A Bela, você deve ter feito pesquisa com ela, ela gosta das mesmas coisas do que eu. [...] Eu recomendei o Anderson Silva, dos desenhos, né [...] Daí ela tá desenhando lá.

Júlia (menina, 10 anos, renda alta): Sim! [...] Hoje mesmo minha amiga me indicou um canal no YouTube chamado Dear Maidy [...] Tem vários fatos sobre a Disney. Minha amiga ama a Disney!

Amanda (menina, 9 anos, renda alta): Cara, têm vários [indicações de amigos]. A Rafa, uma amiga minha da escola, ela me indicou um vídeo de um canal que eu assisto até hoje!

No entanto, nem sempre essa troca entre pares ocorre de maneira totalmente fluida, uma vez que nem todas as crianças possuem as mesmas iniciativas e preferências. Algumas vezes, as crianças relatam que mandam vídeos para seus pares, mas esses não os veem ou não gostam. Outras vezes, são as crianças participantes que não gostam tanto daqueles conteúdos que são compartilhados.

Li (menina, 10 anos, renda alta): Sim. Eu sempre recomendo vídeos pra minhas amigas, mas geralmente elas não veem.

Eu: Aham. Por que elas não gostam?

Li fala em tom triste: Não... É porque geralmente elas... Quando eu falo pra Laura, ela fala que já tá vendo outra coisa, aí ela esquece e eu tenho que lembrar ela.

Luana (menina, 9 anos, renda baixa): Não. Tem vezes que ela indica, aí eu vejo, mas se eu não gostar, aí eu não assisto mais.

Eu: Teve algum que ela indicou e você não gostou?

Luana: Uhum, sim [...] Eu não lembro o nome direito, mas lembro que uma era Anna Laiza e a outra era uma tal de Lili, mas eu não lembro o nome do canal direito.

Eu: E por que que você não gostou?

Luana: É que... Eu gosto mais dos vídeos que faz vlog, e... Elas, a vozinha é muito "nheee"

Dezembro (menino, 10 anos, renda alta): Já. Me mandam no WhatsApp. Eles botam coisa que eu não gosto, às vezes.

$\mathrm{Eu}:$ Ah é? O que eles mandam que você não gosta?

Dezembro: De... De um jogo que eu não gosto, tô estressado com esse jogo porque eu briguei com meu amigo por causa desse jogo.

Nina (menina, 8 anos, renda alta): É, elas [amigas] não gostam muito desses negócios... Se for a minha prima, ela não gosta muito dessa pessoa que eu vejo porque ela acha que a voz dela é irritante. 
A maioria das crianças relatam ter gostos parecidos com alguns de seus pares, não todos. E ter gostos parecidos não significa que eles vão consumir os mesmos conteúdos nem gostar sempre dos conteúdos indicados. Em geral, elas apontam que os tipos de vídeos preferidos podem ser parecidos, mas não necessariamente os canais - o que reforça ainda mais o resultado tão diversificado que foi encontrado no levantamento desta pesquisa em relação aos canais. Gabo e Li explicam:

Gabo (menino, 8 anos, renda baixa): Já que eles [amigos] gostam, praticamente dos mesmos canais, dos mesmos jeitos... Não dos mesmos jeitos, não dos mesmos canais, mas os canais são muitos parecidos, então a gente vê.

Li (menina, 10 anos, renda alta): Não, a gente gosta do mesmo conteúdo, mas dos mesmos canais não. Tipo, T3ddy a Mariana vê, mas a Isabel não vê, que é minha outra melhor amiga. Tipo, Final Level Isabel vê, mas Mariana não vê. Aí fica meio termo.

Assim, nesse diálogo de idas e vindas, as crianças vão estabelecendo suas preferências, compartilhando aquilo de que gostam e se diferenciando de seus pares. Um dos maiores fatores que diferencia os pares é o gênero (CORSARO; DONNA, 1990). Como vimos no levantamento, os meninos e meninas possuem preferências específicas de conteúdo, principalmente em relação aos canais a que assistem. Tendo isso em mente, perguntei às crianças se elas achavam que no YouTube havia vídeos só para meninas e outros só para meninos.

Das 30 crianças, 27 relataram que não há restrição de gênero nos vídeos do YouTube, que todas as crianças podem ver todos os vídeos. Cinco delas inclusive pareceram indignadas com a minha pergunta, como se fosse óbvio que essa separação não existisse. Algumas até fizeram a separação do que é vídeo para menino e para menina, mas consideraram que isso restringe as opções, como explicam João e Vitória:

João (menino, 9 anos, renda baixa): É, porque... Ó, eu assisto vídeo que é pra menina, recomendo pra Bela, e a Bela vai ver a mesma coisa que é pra menino. Que que tem? Que que tem isso? [...] Tipo, eu assisto Livia Inhudes, não tem nenhum problema!

Vitória (menina, 9 anos, renda alta): Não! Tem menina que gosta de vídeo de maquiagem, tem menina que gosta de futebol. Todos são de todos! 
Apenas 3 crianças responderam que existem sim vídeos só para meninos ou meninas. Essas foram as únicas crianças que não apresentaram em sua fala esse conceito de fluidez, onde as crianças possam transitar entre quaisquer vídeos que desejarem na plataforma. Apesar de a grande maioria ter dito que não há uma restrição, 20 das 27 disseram que existem sim preferências entre os gêneros, ou seja, tipos de vídeos que meninos podem gostar mais que meninas e vice e versa. Isabela resume bem esse pensamento:

Isabela (menina, 9 anos, renda alta): Não, não acho não. Depende, tipo... Não, acho que não. Acho que, tipo, todos os vídeos são pros dois sexos [...] acho que depende. Porque tem muito menino também que se maquia, tipo... As meninas, eu tenho certeza que elas veem mais do que os meninos, mas assim, eu acho que, não tem pra cada sexo não. Mas eu acho que maquiagem as meninas veem mais por que eu acho que tem mais meninas do que meninos que se maquiem.

Quando eu pergunto quais são essas preferências de meninos e meninas, as crianças relatam como de meninos os vídeos de jogos, de ação, luta e futebol e de meninas vídeos de maquiagem, boneca e slime. Realmente, essas categorias apontadas por elas correspondem aos resultados do levantamento desta pesquisa. Entretanto, nessa análise mais qualitativa, algumas vezes as próprias crianças não se encaixam nos exemplos citados, como é o caso de Lulu e Ronaldo:

Lulu (menina, 8 anos, renda alta): Eu acho que meninas gostam mais de vídeo de slime, mas eu, eu não sou assim, eu vejo vídeo de jogo, eu vejo tudo. E os meninos gostam mais de jogo, futebol, essas coisas.

Ronaldo (menino, 10 anos, renda alta): Futebol eu não curto muito não.

Eu: Seus amigos curtem? [...]

Ronaldo: Curtem! Pra "dedéu".

Assim, mais uma vez, vemos as características que fazem as crianças se aproximarem e se diferenciarem em suas culturas de pares. Aqui, elas parecem entender que existem sim diferenças entre as preferências de meninos e meninas, mas não veem essas diferenças como estereótipos sociais que as limitem em relação aos conteúdos a que podem ou não assistir no YouTube. Esse achado se distancia um pouco dos relatos das crianças participantes da pesquisa de Ribeiro (2020), que fizeram essa distinção de gênero de forma mais explícita e classificatória.

O último aspecto sobre a cultura de pares é em relação aos pares de as crianças participantes terem seus próprios canais no YouTube. Das 30 crianças que participaram da pesquisa, 24 relataram ter amigos, primos ou irmãos que têm canal no 
YouTube atualmente, ou que já tiveram há um tempo. Isso reforça como a presença das crianças como produtoras de conteúdo no YouTube também é forte, por mais que muitas levem isso como uma brincadeira, e não como uma tarefa (DALETHESE, 2017).

Conforme já apresentado, as crianças não citam muitos canais de youtubers mirins como seus favoritos, mas será que elas se engajam então nos canais de seus pares? A resposta é que depende. As crianças assistem aos canais e se engajam quando o assunto é interessante para elas, independentemente de ser de pares ou não. Poucas crianças relatam consumir os conteúdos simplesmente por conta da amizade, como é o caso de Bruno:

Bruno (menino, 9 anos, renda baixa): Eu não gosto muito não, mas eu só assisto porque eu tenho, é a minha amiga.

A maioria das crianças apresenta respostas mais parecidas com a de Li e Dezembro, que deixam claro que não é porque são amigos que precisam consumir o conteúdo:

Li (menina, 10 anos, renda alta): Assisto. Às vezes, quando parece legal, eu assisto [...] Mesmo sendo minhas amigas, o conteúdo eu posso não me agradar a mim.

Dezembro (menino, 9 anos, renda alta): Não [assiste canal de pares]... Os dois fazem de games, esse Fanático por Games faz, que é o meu amigo e meu primo também faz. E o outro fez um vídeo no museu da imaginação, imagem e ação, não sei, lá em São Paulo. Aí ele tem mais vídeos também. Um de jogo, que ele fez, outro com a irmã dele, não sei... Eu não vejo mesmo quase, por causa que eu gosto ver alguns youtubers que eu mais gosto.

Dezembro ressalta que, mesmo conhecendo o que os amigos estão postando, ele tem sua preferência por assistir aos seus youtubers preferidos, a que já tem o costume de assistir sempre. O grau de engajamento que a criança tem com o canal dos pares parece variar de acordo com o interesse nos conteúdos postados e do grau de amizade que é estabelecido. Foi comum que as crianças citem saber que colegas de sala, por exemplo, têm canais, mas nem saberem o nome ou conteúdos que são postados:

Gabo (menino, 8 anos, renda baixa): Não conheço, não. Mas eu tenho alguns amigos que têm canal no YouTube, mas... Eles... Eu não sei o nome dos canais deles. Mas, o meu amigo Leandro ele tem um canal sim.

Eu: Você assiste os vídeos dele? 
Gabo: Não, porque ele não falou nada ainda nesse canal, ele começou em 2018 também e não falou nada pra mim, não falou o nome do canal. Eu pergunto ele toda hora, mas...

Luiza (menina, 9 anos, renda média): Ah, tem uma amiga que tem sim [canal]. $E$ Joana e Catarina.

Eu: E elas fazem vídeo de que?

Luiza: Eu não sei... Elas não me falaram.

Micaele (menina, 9 anos, renda média): Eu não sei, eu nunca vi, ela nunca me falou, ela nunca me falou o nome [...] Eu vou pedir ela depois o nome do canal.

Ou seja, parece que o engajamento em canais de outras crianças não é tão grande nem quando essas outras crianças são conhecidas. Na próxima seção tentaremos entender um pouco mais esse motivo. O que acontece aqui também é que todos os canais de pares parecem se configurar realmente como uma brincadeira, um espaço de expressão, com fluidez para ser deletado e reativado quando necessário, assim como visto na pesquisa de Dalethese (2017). Camila relata, por exemplo, que sua amiga desistiu do canal por falta de interação:

Camila (menina, 8 anos, renda média): Minha amiga deletou o canal.

Eu: Deletou? Por quê?

Camila: Que ela tava cansada, que ninguém dava like, só eu.

Eu: E ela postava vídeo de que?

Camila: Ela postava vídeo de vlog, de desenhando [...], como fazer... Como é aqueles? Aqueles negocinhos? De estilismo, picadinho de papel colorido? Mosaico!

Eu: Aí só você via?

Camila: É. Dava comentário fofo, eu fazia apoio pra ela. Ela até ficou triste, porque eu fui dar like, eu até dei 31 like.

Quando a amizade é mais forte, ou é o canal de alguém da família, é comum as crianças incentivarem mais, engajarem no canal e até mesmo participarem de alguns vídeos, como por exemplo de desafios. Algumas crianças relatam quererem ser youtubers igual ao primo ou à prima mais velha, o que ressalta uma ideia de inspiração que também pode ser relacionada a outros youtubers adolescentes ou adultos.

Pudemos ver aqui que o YouTube é um lugar potente para gerar muitas trocas entre pares, principalmente quando os pares compartilham entre si preferências semelhantes. Entretanto, pudemos perceber também como as individualidades de cada criança se destacam, com seus usos e sentidos únicos que atribuem à plataforma e aos conteúdos, independente do que outras pessoas pensem. 


\section{3 .3}

\section{A Reiteração}

A reiteração é o eixo das culturas infantis que se refere à não linearidade temporal, em que as crianças podem vivenciar processos que são reinventados, reiniciados e repetidos (SARMENTO, 2003a). Sarmento (2003a) explica que esse tempo não linear se exprime tanto no plano diacrônico, com a transmissão de brincadeiras e rotinas já vivenciadas anteriormente e repassadas de geração a geração, quanto no plano sincrônico, na recriação e repetição das rotinas e situações da própria criança. Assim, a partir dessas continuidades e rupturas, as crianças constroem seus fluxos de interação com as outras pessoas, assim como suas rotinas, que repetem coisas que já foram feitas no passado, mas também incorporam o novo.

Aqui discutiremos essas continuidades e rupturas a partir das preferências pessoais e únicas das crianças, no plano sincrônico, e as possíveis transmissões de rotinas e valores dos youtubers mais velhos para as crianças que a eles assistem, no plano diacrônico. Sabemos que esse é um processo fluido e, como já dito, não linear, então veremos como as crianças estão dando significado a tudo que veem de uma maneira muito mais rica do que se fosse algo estático e simplificado.

\section{As preferências pessoais das criancas}

Ao longo de toda a apresentação dos resultados, vimos que as preferências das crianças são muito únicas, apesar de determinadas temáticas serem frequentes para a maioria delas. Elas têm seus canais favoritos, independente de serem os favoritos de amigos ou de seus responsáveis falarem mal. Elas têm seus motivos específicos para interagirem com os youtubers e suas opiniões sobre o funcionamento da plataforma. Existe sim uma cultura infantil e uma cultura de pares que é compartilhada, mas, a partir dela, as crianças parecem ir descobrindo suas preferências pessoais, se diferenciando do grupo em certos aspectos e construindo suas próprias rotinas e significados.

É comum que a gente veja as crianças querendo assistir sempre aos mesmos filmes, ou brincar das mesmas brincadeiras, sem entender muito bem como no meio de tantas opções, elas queiram sempre o mesmo. No YouTube isso também parece acontecer. As crianças reconhecem a infinidade de opções que têm, mas, dentre 
todas aquelas, elas elegem suas favoritas e são essas opções que a criança vai consumir cotidianamente - até talvez achar uma outra opção que agrade mais. E, mesmo com os youtubers postando, muitas vezes, vários vídeos por semana, algumas crianças me relataram assistir aos vídeos repetidamente:

Lulu (menina, 8 anos, renda alta): Eu sempre vou no canal que eu gosto, e depois eu vejo vídeo novo, se não tiver vídeo novo eu assisto os repetidos mesmo.

Eu: Ah é?

Ronaldo (menino, 9 anos, renda alta): É, eu faço a mesma coisa!

Vitória (menina, 9 anos, renda alta): Às vezes eles apagam os vídeos, aí eu vou ver um vídeo que eu queria ver de novo mas já tinha apagado.

Assistir ao YouTube faz parte da rotina destas crianças, e, mais especificamente, seus youtubers favoritos fazem parte do dia a dia delas:

Dezembro (menino. 9 anos, renda alta): Ah, porque foi um youtuber que quando eu chegava do colégio eu sempre via, eu me distraia.

Quando eu perguntava quais eram os canais preferidos das crianças, dificilmente elas me traziam uma lista extensa, mas elencavam com firmeza qual era(m) o(s) favorito(s), como Gabo:

Gabo (menino, 8 anos, renda baixa): Eu gosto muito de ver Vosso Canal, mas também não é meu canal favorito, preferido.

Eu: Vosso Canal... E qual é o preferido, então?

Gabo: É o canal Desimpedidos. É um canal parecido, mas pra mim eu acho melhor.

Em diversos momentos da entrevista, as crianças expressavam tais preferências por canais ou youtubers específicos. Ao todo, foram 86 citações de momentos como esse, em que a criança dizia sua preferência de maneira enfática, diferenciando aquele canal de outros ou até mesmo diferenciando seu gosto do gosto de seus pares. Esse ponto já foi abordado em todos os outros tópicos anteriores, mas a partir dessas falas de Lulu e Isadora conseguimos entender mais ainda como essa diferenciação se dá:

Lulu (menina, 8 anos, renda alta): Indicaram e eu vi. Só que a maioria de o que eles me indicaram eu não gostei, eu tenho péssimo gosto pro gosto dos meus amigos e é isso.

Isadora (menina, 10 anos, renda baixa): Minhas amigas só gostam de BTS e Black Pink. Mas têm duas delas que não gostam, só gostam de funk. Eu não tipo daquelas 
meninas que não gostam de fazer nada de, tipo, lavar louça. Eu gosto de lavar louça. Tipo, as meninas gostam de passar maquiagem. Eu não gosto. Tipo, funk, não gosto.

Conseguimos ver então como as crianças vão se diferenciando de seus grupos de pares e tendo suas próprias preferências nesse plano sincrônico. Isso não significa, entretanto, que não compartilhem com seus pares, nem que continuem com as mesmas preferências sempre, como aponta Vitória:

Vitória (menina, 9 anos, renda alta): Antes eu assistia muito Bela Bagunça, mas agora eu não assisto mais [...] Ela foi ficando mais velha e os conteúdos eu não fui gostando mais do conteúdo.

Assim, o YouTube oferece a possibilidade de as crianças encontrarem canais que lhes agradem em cada fase de suas vidas. Mas, por que será que escolhem determinados canais e não outros? Por que será que preferem canais de youtubers mais velhos do que elas? Será que elas se identificam com esses youtubers e os veem como exemplos? Tentaremos entender isso melhor nas próximas seções.

\section{$\underline{\text { A (não) identificação com o youtuber }}$}

Ao longo deste trabalho, foram elencados diversos motivos para as crianças gostarem mais de algumas temáticas do que de outras, assim como preferirem alguns youtubers a outros. Uma das hipóteses que tínhamos era que as crianças talvez procurassem youtubers com quem se identificassem mais, que fossem semelhantes a elas em certos aspectos. Já vimos que em termos de idade, isso não acontece tanto, pois as crianças dessa faixa etária preferem youtubers mais velhos. Mas, em termos de gênero, por exemplo, as crianças optam por assistir aos youtubers de mesmo gênero, principalmente os meninos.

Para entendermos se existiam outros aspectos de identificação, perguntamos às crianças se elas se achavam parecidas com os seus youtubers preferidos, tanto pessoalmente, de aparência ou jeito, quanto de rotina e tipo de vida que têm. Para nossa surpresa, contrapondo os achados de Bezerra (2018), as crianças citaram muitos mais aspectos que as diferenciam dos youtubers do que aspectos que as aproximam. Foram 30 citações ao longo das entrevistas sobre como não se identificavam com os youtubers, contra apenas 14 que apontavam semelhanças entre eles. Essa diferença fica ainda mais acentuada quando pensamos no número de crianças, pois 
27 das 30 disseram que eles não se parecem com os youtubers, enquanto 9 conseguiram achar aspectos que se assemelham.

$\mathrm{O}$ aspecto que as crianças mais apontaram como fator que as diferencia dos youtubers foi a situação financeira deles. Quatorze crianças citaram como eles são ricos, têm casas gigantes e/ou outros bens materiais que elas não têm. As falas abaixo expressam bem isso:

Miguel (menino, 8 anos, renda baixa): Eles moram numa mansão, tem piscina, eles têm uma moto, têm muito diamante no Free Fire.

Davi (menino, 9 anos, renda baixa): Os caras têm uma casa de 10 mil metros e aí eu tenho um apartamento de um centímetro.

Micaele (menina, 9 anos, renda média): Porque o Lucas Rangel mora em um prédio enorme, a Camila tem uma mansão que tem até uma quadra e a Bela Almada mora em um condomínio enorme.

Geremias (menino, 9 anos, renda alta): A casa que eles [Família Arqueira] moram, tem um elevador! Então não é nada parecido com a minha, a minha não tem nem escada [...] Tem três andares.

Podíamos esperar que talvez as crianças de famílias de renda mais baixas relatassem mais esse aspecto do que as de rendas mais altas, mas na verdade isso não acontece. Parece que mesmo as crianças de rendas altas se veem em uma realidade muito diferente das dos youtubers, justamente por eles possuírem bens materiais como casas enormes que demonstram como eles de fato têm muito dinheiro. Li, que é de uma família com renda mensal de mais de 10 salários mínimos, até chega a brincar dizendo que eles são ricos e ela é pobre, possivelmente apontando a lacuna entre as realidades:

Li (menina, 10 anos, renda alta): Não. Porque eles são ricos e eu sou pobre! Não, mentira, eu não sou pobre, mas sou classe média [...] Eles também têm a vida muito divertida, são mais velhos do que eu...

Apesar de crianças de todas as rendas expressarem essa diferença financeira entre elas e os youtubers, sabemos que isso impacta com pesos diferentes na realidade deles. É possível achar em comentários de crianças em vídeos de youtubers mirins desejando que também fossem ricas para poder ter as bonecas que a youtuber tem, ou fazer as viagens que ela faz (TOMAZ, 2017). Um exemplo aqui é o de João, de renda baixa, que relata mais de uma vez na entrevista como gostaria de ter alguns bens materiais que os youtubers têm: 
Eu: Você acha sua vida parecida com a vida dele [JPDragon]? Vocês se acham parecidos?

João (menino, 9 anos, renda baixa) responde rindo: Não, peraí! Ah, aí não vale, né? Que ele é um canal de jogo. Os jogos que ele têm, eu não tenho [...] Ele tem Fortnine, Minecraft - Minecraft eu tenho -, Naruto, Dragon Ball, Jump Force... Eu não tenho esses jogos!

[...]

João: Eu não tenho... Assim, a Mayara Rodrigues e o Art Lucas, a vida deles não são nada parecida com a minha! Porque eles têm os materiais, e eu não tenho os materiais que eles têm. Só tenho lápis de cor, apontador, borracha, lápis, lapiseira, caneta...

Enquanto isso, Nina, de renda alta, que também se diferencia dos youtubers dizendo que a casa deles é maior, reconhece que ela tem outras experiências até mesmo mais interessantes que as dos youtubers:

Nina (menina, 8 anos, renda alta): A casa delas [youtubers] não é nada parecida com a minha, porque elas moram numa casa que tem elevador exclusivamente pra três tipos de andares [...] Casas incríveis! Mas isso não liga porque eu já fui em 10 países, né, então eu já fiz muitas mais viagens do que elas!

Então, é importante entendermos a realidade social de cada criança para contextualizarmos as respostas dadas. Mas, de fato, o que une todas elas independente de renda é essa não identificação de vida com os youtubers a que assistem. Isso parece ir além da questão financeira, envolvendo também aspectos do tipo de vida e rotina que eles levam:

Isadora (menina, 10 anos, renda baixa): E tipo, a gente não faz vídeos de vez em quando, e... A gente... Não se veste muito igual eles.

Sabrina (menina, 9 anos, renda baixa): Elas brincam toda hora de coisas diferentes.

Luiza (menina, 9 anos, renda média): Ela [Luluca] faz vários desafios, e eu não faço nenhum.

Bruno (menino, 9 anos, renda média): Não [...] Eles vivem com mais pessoas, numa casa gigante.

As crianças se referem a aspectos do cotidiano que veem nos vídeos, mostrando a elas como a vida dos youtubers é diferente, por eles gravarem vídeos, fazerem desafios e brincadeiras e até mesmo viverem com mais pessoas, como aponta Bruno. Outro aspecto levantado é como os youtubers são mais proficientes nos jogos do que as crianças, que por sua vez se consideram noobs, como já explicado anteriormente. Tudo isso faz com que as crianças se vejam distantes dos youtubers, com dia-a-dia e rotinas muito diferentes. Li explica que gostaria muito de poder 
fazer o mesmo que os youtubers fazem, estar em uma casa grande se divertindo com os amigos:

Li (menina, 10 anos, renda alta): O Final Level, é que tipo... É o sonho de toda pessoa! Tipo, ver vários youtubers juntos, numa mesma casa, fazendo pranks, que é trollagens, pegadinhas, fazendo pegadinhas, trollagens, tipo, coisas juntos... Teve uma vez que eles fizeram um tobogã na piscina deles, que tipo, eles faziam desafios tipo, quem desce mais rápido, quem sobe mais rápido.

Eu: Aham. Você queria estar em uma casa assim com suas amigas, por exemplo?

Li: Aham! Ficar na casa com todas as amigas brincando e se divertindo! Até Cross Fit tem na casa!

Aqui vemos então que, apesar de a maioria das crianças entenderem que ser youtuber dá trabalho, muitas vezes eles associam a vida deles a algo muito divertido, onde eles estão sempre brincando e cercados de amigos. Isso indica novamente como os aspectos de ludicidade e interatividade são caros para as crianças.

Das 9 crianças que mencionaram que se parecem com os youtubers, 4 disseram ser por algum aspecto da rotina que é semelhante, como por exemplo jogarem os mesmos jogos, comerem coisas parecidas ou passearem nos mesmos lugares. Duas crianças que gostam de youtubers mirins ressaltaram a idade ser parecida, e outras duas destacaram características físicas.

Buscando tentar entender a preferência das crianças por youtubers mais velhos, eu perguntei a algumas delas se havia algum motivo para isso, mas a maioria não soube me responder. O Davi, menino de 9 anos de renda baixa, me explicou que youtuber mirim só é bom se a criança souber editar bem e postar vídeos sempre, corroborando com o que a criança-investigadora da pesquisa de Ribeiro (2020) apontou sobre a possível menor competência técnica desses youtubers. Amanda e Li também se aprofundaram nesse assunto, dando suas opiniões sobre o tema:

$\mathrm{Li}$ (menina, 10 anos, renda alta): É porque quando são de criança geralmente eles são muito infantis. Tipo, a criança...

Amanda (menina, 9 anos, renda alta) interrompe falando alguma coisa e concorda com a cabeça.

Li continua: Tipo, tinha um canal, que tipo, que era da Planeta da Gêmeas, eu vi o vídeo e era bem mais infantil. Tipo, o público adulto, faz pro público adolescente, mais ou menos essa faixa. E pra mim o público de 10 anos mais ou menos, faz vídeo pra uns sete, seis... Pelo menos isso que eu vi!

Eu: Ah, vocês acham que a maioria do pessoal, então, da idade de vocês, faz vídeo pra criança menor?

Li: Uhum. No Gasha eles não mostram a voz e tipo, parece [Amanda interrompe e fala: só mostra a animação] mas se eles nem são crianças, são pré-adolescentes.

Eu: Entendi. E você concorda Amanda? Com isso que a Li falou? 
Amanda: É, mais ou menos. Depende do youtuber, tipo... Eu, tipo, tem uma youtuber que eu assisto, Cara... Que eu assisto desde que eu era pequenininha, que eu assisto às vezes até hoje, não assisto tanto, mas eu ainda assisto. Juliana Baltar. Ela começou a ter um conteúdo mais pra minha idade, sabe? Não é mais aquele conteúdo pra seis anos e tal, porque ela foi crescendo e foi evoluindo. O canal dela foi evoluindo junto.

Li: Tipo, tem um canal que o nome é Victória Mineblox, que ela tem a mesma idade que eu, mas eu acho que o conteúdo é pros oito, sete.

As hipóteses traçadas pelas meninas são bastante coerentes. Elas apontam que certos youtubers mirins acabam criando conteúdos direcionados para crianças mais novas. Amanda explica que quando o canal evolui junto com o crescimento da criança, o público muda, uma vez que os interesses de crianças pequenas e crianças maiores é diferente. Complementando o que as meninas falaram, o que pode acontecer é que aquela criança que começa a fazer vídeos muito nova, às vezes quando cresce continua fazendo vídeos para uma audiência daquela faixa etária, deixando de interessar aos seguidores que também cresceram e não se interessam mais por aquele assunto. As crianças dessa faixa etária da pesquisa parecem então recorrer aos youtubers jovens adultos - nomenclatura também criada por Amanda e Li, por não saberem classificar se uma youtuber com 20 anos de adolescente ou adulto:

Amanda (menina, 9 anos, renda alta): Cara... Não, ela [Bibi]... Ela tem 20 anos. Ou seja, eu não sei se ela é adulta ou não é, porque pra mim isso não é adulto ainda.

Essa confusão talvez aconteça pelo fato de as crianças verem esses youtubers sempre se divertindo, jogando, brincando, coisas que não associam com adultos. Apesar de a ludicidade ser presente na vida de todos, a idade adulta acaba valorizando muito mais o trabalho do que a brincadeira (BROUGÈRE, 1998), e, no caso dos youtubers, as duas coisas parecem se misturar. Bela demostra essa ideia em sua fala:

Eu: A Julia [Minegirl] ela é criança também, ou não? Quantos anos ela tem?

Bela (menina, 9 anos, renda baixa): Ela [Julia Minegirl] não mostra nem o rosto, nem a idade, então...

Eu: Ah, tá. Mas ela é adulta? Ou você não sabe?

Bela: Eu acho que ela é adolescente, porque adulto não gosta de Roblox.

Outra ideia que apareceu na fala das crianças é a de que elas não conhecem de fato a vida dos youtubers, apenas aquilo que eles mostram nos vídeos. Isso 
demostra uma sofisticação das crianças em entenderem que o que está atrás das telas não representa toda a vida real.

Nina (menina, 8 anos, renda alta): Eu não conheço quase nada da vida deles, desses youtubers.

Ronaldo (menino, 10 anos, renda alta): Olha, eu não conheço tanto ele, só assisto o vídeo.

Pesquisas anteriores (BEZERRA, 2018; SATLER; CARRIJO, 2019) apontaram como algumas crianças veem os youtubers como amigos próximos, como pessoas "normais" como eles. Isto parece estar sendo desconstruído na fala das crianças desta pesquisa, que veem sim os youtubers como pessoas queridas, que os divertem e os entretêm, mas que não são tão próximos e semelhantes assim. Kaique, de 8 anos, aponta ainda como ele acredita que seus youtubers favoritos não gostam verdadeiramente daquilo que fazem:

Kaique (menino, 8 anos, renda baixa): A Rafa e o Luiz são adultos, e o JP também. Adolescente!

$[\ldots]$

Eu: Você acha eles parecidos com você?

Kaique: Não [...] Porque... Eles não... Eles não são muito parecidos comigo, eles não gostam das coisas que eu gosto.

$\mathrm{Eu}$ : Hm, tipo o quê que você gosta que você acha que eles não gostam?

Kaique: Eles não gostam de aventura, não gostam de terror... Só que eles gravam porque quer ganhar fama.

Essa ideia de o youtuber não ser tão verdadeiro assim apareceu na fala de mais algumas crianças, apontando como elas nessa faixa etária já conseguem diferenciar mais o que é a realidade e o que pode estar por trás das câmeras. Da mesma forma, é esse senso crítico que parece ajudar as crianças a optarem por aqueles youtubers que têm atitudes que condizem com o que acreditam, se afastando daqueles que não têm. Gabo explica, por exemplo, como não se identifica com alguns youtubers, que podem ser influências ruins:

Gabo (menino, 8 anos, renda baixa): Pra mim, os youtubers é... Eu se identifico com a maioria deles, mas não com todos. Porque existem aqueles youtubers que zoam as pessoas, ou fazem coisas que elas não gostam, que você é... Influenciam elas a fazerem coisas ruins. Falam nos vídeos que são coisas boas, mas quando a gente tenta fazer, a gente percebe que aquilo foi uma coisa que a gente nunca deveria ter feito.

Na próxima seção entraremos de forma mais aprofundada nas questões que Gabo trouxe. Já sabemos que as crianças em geral não se veem tanto como 
semelhantes aos youtubers, mas será que elas querem ser como eles? Será que as crianças os veem como exemplos a serem seguidos?

\section{Youtubers são bons exemplos?}

Em determinado momento da entrevista eu perguntei às crianças se elas consideravam os youtubers bons exemplos ou não, tanto os preferidos delas quanto em geral. Foram 32 citações de momentos em que as crianças citaram que os youtubers eram maus exemplos e 31 citações de bons exemplos, o que indica um equilíbrio na percepção das crianças. Em geral, elas consideram os youtubers a que assistem como bons exemplos, mas poucas trazem em suas falas um tom forte de admiração ou de que se inspiram neles como Li e Gabo:

Li (menina, 10 anos, renda alta): Sim [youtubers são bons exemplos]. O Felipe Neto eu acho porque ele, antes ele... Ele era pobre, ele admite que era pobre, e virou um grande youtuber, o segundo maior youtuber do Brasil. E ele começou num quarto, sem decoração nenhuma. Num quarto gravando vídeo sem decoração nenhuma.

Eu: Uhum. E por que que você acha que esse é um bom exemplo, então? O que que isso te diz, assim?

Li: Porque mesmo você sendo pequeno no início, você pode se tornar grande.

Gabo (menino, 8 anos, renda baixa): Pra mim, o Desimpedidos, o Ginga Street e o Vosso Canal, fazem paródias, fazem músicas, né, inventam músicas que inspiram as pessoas a fazerem o que que fazem, que no caso é jogar futebol, treinar, se destacar até o fim.

Isabela e Diego, por sua vez, explicam que o youtuber só seria um bom exemplo para aqueles que desejam seguir suas carreiras, e que para as outras crianças essa questão do exemplo seria indiferente:

Isabela (menina, 9 anos, renda alta): Então... Não é que são bons exemplos, mas também não são ruins! Por que assim, jogar não vai fazer diferença na nossa vida, entendeu? Mas depende, porque tem gente que trabalha com isso né, tem gente que ganha dinheiro só com isso. E, não sei, se eu quiser ser uma youtuber quando crescer, pode seguir como exemplo, se elas forem bem e tal. Se elas ensinarem tipo, porque eu vejo uns canais que elas ensinam algumas coisas tipos, "ah, gente bebe água todo dia, pra ficar hidratada", "come uma fruta todo dia, eu desafio você a comer uma fruta todo dia", aí eu acho que é um bom exemplo. Mas assim, não é que é um bom exemplo nem ruim, né? Porque elas jogam! Então, não é algo ruim, mas também não é bom, isso não vai fazer diferença na minha vida.

Diego (menino, 10 anos, renda alta): Se eu virar, se eu for virar um jogador bom pra eles vai ser bom, eu vou aprender com eles. Mas se eu não quiser virar um jogador muito bom, um pro player, essas coisas, não. 
A maioria das crianças que apontam o youtuber como bom exemplo, não trazem, então, esse carácter forte de admiração e inspiração. Elas relatam considerar o youtuber como bom exemplo ou "mais ou menos bom exemplo" simplesmente por ele conseguir diverti-las, ou por não ensinar a fazer nada de errado:

Gabrielle (menina, 8 anos, renda baixa): Porque [é um bom exemplo]... Quando a pessoa está triste, ele vai tentar fazer... Vai animar a pessoa.

João (menino, 9 anos, renda baixa): Se você tem certeza que o canal é bom mesmo... Tipo, eu só assisto canal de animação, desenho... Eles não vão me ensinar mau de desenho, nem animação! Eu só vejo o vídeo, e já tá animado!

Bruno (menino, 9 anos, renda baixa): Mais ou menos [bons exemplos]. Ah sei lá, porque a gente não aprende muita coisa, mas também é legal.

Júlia (menina, 10 anos, renda alta): Porque nos vídeos ela [Luluca] nunca faz, assim, as coisas erradas, sabe? É porque ela tem quase a minha idade. E criança não faz muito essas coisas.

Bela (menina, 9 anos, renda baixa): A Julia [Minegirl] ela é boa porque ela se diverte e diverte a gente também.

Sophia (menina, 10 anos, renda baixa): E o da Loud, eu acho mais ou menos [bom exemplo], porque... $O$ da Loud eles não xingam, eles só ficam jogando um jogo e brincando, às vezes.

Assim como se achava que conteúdos bons para criança na televisão eram aqueles que não apresentavam violência (FUENZALIDA, 1996), aqui as crianças parecem considerar que conteúdos bons são aqueles que divertem sem o youtuber ensinar nada de errado. Elas parecem escolher assistir no YouTube aqueles youtubers que consideram, junto ou não com suas famílias, como corretos e adequados a elas. Algo interessante que apontam é como prezam pelo cuidado que alguns youtubers têm de avisar quando algo não é para fazer em casa, ou colocar classificação indicativa em seus vídeos. Algumas crianças relatam ver isso como um cuidado que o youtuber está tendo com elas e que, em geral, dizem respeitar tais recomendações.

Amanda (menina, 9 anos, renda alta): Não ensinando uma coisa errada, mas tipo, eles podem em algum momento... óbvio que eles podem em algum momento ensinar coisa errada porque.... porque eles são adultos já, e os conteúdos errados têm escrito "+13" então, eu acho que sim, eles já fizeram conteúdos errados, mas eu não vejo.

Li (menina, 10 anos, renda alta): interrompe e fala: Tá, mas tava "+13"!

Amanda: É, tava "+13", mas eu não vejo. Eu não vejo.

Li: Nem eu.

Eu: Entendi. Aí esses vídeos sim eles podem ensinar coisas que não são boas pra sua idade, por exemplo. 
Amanda: Uhum.

Eu: E vocês acham bom eles avisarem, então, que é +13 ?

Li: Sim!

Amanda concorda também.

Li: Ou se for falar palavrão, censurar!

As crianças expressam ter consciência de que os youtubers podem ter atitudes ou falar coisas que não são apropriadas para sua idade. No caso de Amanda e Li, elas optaram por continuar vendo os conteúdos, mas não aqueles que não são recomendados. Em outros casos, quando as crianças identificam youtubers que são maus exemplos, elas em geral dizem se afastar desses. Nesta pesquisa, o youtuber mais citado como mau exemplo foi o Felipe Neto - que também foi o mais citado como preferido no levantamento, sendo o $3^{\circ}$ youtuber com mais inscritos no Brasil (SOCIAL BLADE, 2020). Conforme já explicado anteriormente, ele e seu irmão Luccas Neto já se envolveram em diversas polêmicas no passado e as crianças ouvem falar sobre isso:

Gabo (menino, 8 anos, renda baixa): Olha, na última coisa que eu tava pensando agora, era Felipe Neto que eu ia falar. Porque, o Felipe Neto, eu acho que, como ela disse, ele dá muito má influência, como o irmão, que é o Luccas Neto. Primeiro porque eles são botafoguenses (risos), e eu sou flamenguista. Segundo que mesmo o Luccas Neto fazendo papel de criancinha, como ela disse, ele xinga, o irmão dele também xinga... E também, a gente não pode só ver os youtubers da forma quando eles estão gravando vídeos, tem que ter uma forma da gente acompanhar o que eles fazem por trás das câmeras.

Camila (menina, 8 anos, renda média): Quase... Todas as minhas amigas ficam falando que é um mau exemplo, porque, eu tenho uma amiga que ela [...] Eu tenho uma amiga que ela fala que é um mau exemplo o Felipe Neto, porque ela vai muito na igreja e ela não gosta de palavrão.

João (menino, 9 anos, renda baixa): Felipe Neto não ensina muita coisa boa. Davi (menino, 9 anos, renda baixa): Eu posso dizer nem Luccas Neto, nem Felipe Neto.

João: Luccas Neto eu assistia, só que depois eu vi a reportagem, ele falando mal das crianças, eu parei de assistir [...] Ele falou assim "mas ninguém aguenta"... Ele fala bem das crianças, só que por trás das câmeras, ele fala assim "ninguém aguenta mais essas crianças mal criadas!"

Eu: E onde você viu essa reportagem?

João: Meu pai me falou, aí ele botou o vídeo e daí eu vi.

[...]

Davi: Olha, por exemplo, você tem que saber que Felipe Neto tem duas coisas: ele é retardado e fala muito palavrão, estou aqui pra falar que ele é um retardadão.

João ri e fala: Aê! Até fez uma rima!

Eu: Você também acha, João, que ele fala muito palavrão?

João: É, sim. Só que agora na saga Minecraft ele não fala mais. 
Gabo aponta a importância de acompanhar os youtubers por trás das câmeras, que foi justamente o que Davi e seu pai fizeram. O episódio que Davi narra se refere ao começo de carreira de Luccas Neto, quando ele de fato fazia vídeos xingando crianças e outros youtubers. Após um tempo, ele começou a produzir vídeos direcionados para as crianças, mas com forte apelo comercial, novamente sendo muito criticado por famílias e educadores (LUZ, 2018). Só na metade de 2018 que Luccas resolveu reformular todo seu conteúdo, contratando uma equipe de psicólogos e pedagogos para auxiliá-lo a produzir vídeos que agregassem mais para as crianças. Toda essa trajetória foi resumida pelo jornalista Chico Felitti, em uma reportagem para a Folha de São Paulo (2019). Luccas não foi tão citado quanto seu irmão Felipe pelas crianças desta pesquisa, por atualmente produzir conteúdos direcionado para crianças menores, como aponta Camila:

Camila (menina, 8 anos, renda média): É, eu já assisti Luccas Neto. E eu falei assim: "Se ele fosse, tipo, casado, ele ia ser muito bobo". Porque ele é mais pra criança de 3 anos, como meи primo João que tem 5 anos.

A principal crítica que as crianças desta pesquisa apresentaram ao Felipe Neto foi o fato de ele falar muitos palavrões. O youtuber já foi muito criticado por famílias por estar influenciando negativamente as crianças, por conta dos palavrões, xingamentos, ofensas e comportamentos inapropriados (LISAUSKAS, 2018). Entretanto, nos últimos anos, quando começou a receber o público infantil em seu canal por conta dos vídeos de seu irmão, ele também reviu seus conteúdos, sinalizando os vídeos inapropriados para menores de 13 anos e tomando cuidado com o linguajar (SILVA, 2020). De qualquer forma, as crianças ainda apontam críticas pertinentes para o conteúdo do Felipe e do Luccas, independentemente de serem conteúdos atuais ou antigos:

Isadora (menina, 10 anos, renda baixa): Tipo, Felipe Neto de vez em quando ele fala alguma coisa, com o amigo dele. Ele fala maldade de vez em quando [...] É tipo, fala que ele é muito gordo, que ele não pode fazer algumas coisas que ele não pode.

Nina (menina, 8 anos, renda alta): Então, o único youtuber que eu não deveria ter... estar vendo, só alguns vídeos mesmo, que ele dá exemplo pra criança, ele fala palavrão, né?

Eu: Quem é?

Nina: Felipe Neto, é claro. Ele que fala palavrão.

Geremias (menino, 9 anos, renda alta): Muito!

Eu: Fala muito palavrão, Geremias?

Nina: Muito mesmo. 
Geremias: Quando eu vejo os vídeos dele e quando ele fala palavrão, eu... Quando ele fala o primeiro palavrão, eu tiro na hora o vídeo e vejo outro.

Nina: Agora na quarentena, ele parou um pouquinho de falar muito palavravrão, mas no fim ele fala muito palavrão mesmo.

Isabela (menina, 9 anos, renda alta): O Felipe Neto ele ensina tudo de errado! Tipo, não tem nada que ele ensina de certo. E o Luccas Neto ele só ensina a engordar, ele faz muito incentivo de doce.

Games BR (menino, 9 anos, renda alta): Ele desperdiça comida pra fazer bagunça de sabão! [...] Ele grita no ouvido dos vizinhos assim AAAAAA [...] O Luccas Neto ele ensina coisas erradas. O meu irmão tem amigo que vê Luccas Neto e tá aprendendo coisas erradas com isso, porque ele chuta e zoa todo mundo.

O que as crianças apontam demonstra que elas têm consciência de quais tipos de conteúdo não apresentam bons exemplos para elas. E, mais do que isso, elas apontam como crianças que conhecem são influenciadas por esses youtubers, como relata Games BR. Nenhuma criança diz diretamente como ela mesma foi influenciada negativamente por algum conteúdo, pois geralmente elas dizem parar de assistir antes de isso acontecer. Isabela relata abaixo ter parado de assistir a um youtuber de que gostava depois de sua mãe reclamar diversas vezes e ela acabar concordando com a crítica por medo de ser influenciada negativamente:

Isabela (menina, 9 anos, renda alta): Eu vi um canal que o garoto era totalmente "inalfabeto", ele não sabia falar, ele era, tipo, ele falava tudo errado! E eu parei de ver o canal dele, senão eu ia ficar "inalfabeta" também!

O que nós vemos aqui é novamente esse processo dialético das opiniões e vivências das crianças interagindo e se entrelaçando com falas e experiências do mundo adulto, fazendo com que elas construam seus próprios significados (WARTOFSKY, 1999). O YouTube é uma instância cultural assim como qualquer outra que existe na sociedade, junto com a igreja, a escola, a família, os vizinhos. E todas estas instâncias vão mediar os sentidos que as crianças constroem ao assistir a um vídeo, assim como acontecia com a televisão (OROZCO-GÓMEZ, 1991).

Apesar de as crianças terem essa consciência crítica do que talvez não seja bom exemplo para elas, foi mais comum que elas apontassem tais influências em outras crianças conhecidas, e não nelas mesmas. Na pesquisa sobre televisão de Duarte, Leite e Migliora (2007), as crianças participantes também relataram se preocupar mais com a influência negativa da TV em crianças pequenas e adolescentes, se colocando um pouco fora desse grupo que poderia sofrer tal influência. A ideia 
de que as crianças mais novas são mais vulneráveis aos conteúdos negativos pode ser identificado nas falas abaixo:

Bela (menina, 9 anos, renda baixa): Eu acho, aquela menina que tava aqui quando eu tava na outra casa, ela vê muito vídeo que grita, eu acho que ela aprende a gritar, porque hoje ela tá gritando igual uma doida!

Micaele (menina, 9 anos, renda média): Ah, nada [de influências boas]. Mas também quando a gente fica muito assim, querendo ver esse youtuber, a gente não quer focar mais nos estudos [...] Eu tenho uma prima que tá viciada... Ela tem 7 anos, ela ainda tá aprendendo a ler e a escrever. Ela tava fazendo tudo direitinho, aí ela começou... Ela via no YouTube um youtuber super famoso, e tá focada só nele, e ela nenhum dia vai estudar [...] Ela também tá muito focada no TikTok [...] Ela não quer mais focar nos estudos.

Geremias (menino, 9 anos, renda alta): A minha irmã, o que ela aprendeu com o YouTube, o youtuber que ela mais via [...] era Luccas Neto e Gi. Aí, ela aprendeu a comer doce com isso. Agora ela só pensa em doce.

Podemos ver pelos relatos apresentados aqui, então, que as crianças identificam coisas que não consideram certas no YouTube e que entendem que essas coisas podem prejudicar a elas ou a seus pares. Para entendermos melhor esse assunto, iremos agora discutir especificamente essas coisas de que as crianças não gostam na plataforma do YouTube como um todo.

\section{3 .4}

\section{Do que as crianças não gostam no YouTube?}

Em diversos momentos da entrevista, as crianças relataram tipos de conteúdo e atitudes de youtubers que não agradam por determinados motivos. Eu perguntava especificamente se tinha algum tipo de vídeo de que elas não gostavam no YouTube, e também se tinha algo que os youtubers faziam que elas não consideravam muito correto. Acontecia com frequência de as crianças se esquivarem dessas perguntas, dizendo rapidamente que não consomem coisas inapropriadas, e por isso não sabiam me responder. Foram 28 citações em que elas expressavam esse não conhecimento de conteúdos inapropriados. As falas de Gabo e Luana expressam bem isso:

Gabo (menino, 8 anos, renda baixa): Cara, eu nunca assisti nenhum... Nenhum vídeo, nem série que não é pro meu tamanho. 
Luana (menina, 9 anos, renda baixa): Eu não sei, mais ou menos... É porque eu nunca assisti um vídeo que não foi pra minha idade, então eu não sei.

Lembrando que muitas das crianças estavam com responsáveis presentes no mesmo ambiente, essa pode ser uma forma de elas reafirmarem para os responsáveis que não estão consumindo nenhum conteúdo que não deveriam. Porém, ao desenvolver a conversa e/ou criar exemplos hipotéticos, consegui que as crianças expressassem o que elas acham que seria errado para a idade delas ou que elas não gostam na plataforma.

Seguindo a classificação de riscos online de Nogueira (2016) inspirada em Livingstone (2014), podemos organizar os incômodos das crianças nas seguintes categorias: risco de conteúdo, risco de conduta, percepção de sexo, risco tecnológico, risco de contato e percepção de violência. Na pesquisa da autora, se olharmos para os resultados das crianças de 9 e 10 anos, vemos que os riscos mais citados por elas são os de agressão verbal (conduta), terror (conteúdo), pornografia (sexo) e violência (conteúdo). Os resultados desta pesquisa corroboram em parte com esses achados.

O que foi mais citado pelas crianças como conteúdos ruins foram os palavrões (com 31 citações) e os vídeos de terror ou assustadores (com 14 citações), ou seja, também da categoria conduta e conteúdo. Os palavrões já foram bem discutidos na seção anterior, pois essa é a característica que as crianças mais atribuem a um youtuber que não é bom exemplo. O palavrão pra essa faixa etária parece ter um peso muito grande, que, independentemente do gênero e da renda familiar, enxergam falar palavrões como algo "feio", inadequado. Nina exemplifica isso relatando um episódio em que se sentiu culpada e triste por ter falado um palavrão:

Nina (menina, 8 anos, renda alta): Porque falar palavrão na nossa idade é muito feio. Tipo um dia que sem querer, eu tava comemorando a véspera de Natal lá na casa, aí os meus primos, eles tavam, eles não paravam de gritar, porque eu tava gravando um vídeo pedindo pra ir no show do Luccas Neto - eu sei que isso é pra criancinha, mas é porque eu adoro, algumas vezes eu gosto de ver vídeo dele [...] Aí, eles paravam de gritar no vídeo, puxar meu vestido, e aí eu fiquei tão irritada que eu falei um palavrão na frente deles no quarto! [...] Eu comecei a chorar de tanta tristeza, porque eu tava pensando que o Papai Noel não ia querer me dar o negócio, com eu tendo falado aquele palavrão!

Entende-se que essa noção de que criança não pode falar palavrão é algo construído socialmente, possivelmente a partir de uma concepção da criança pura e 
ingênua, que constituiu fortemente o imaginário de infância ao longo das décadas (ARIÈS, 1981b). Isso pode ser visto a partir dos relatos das crianças que fazem referências aos seus responsáveis não as deixarem consumir conteúdos com palavrão, por exemplo.

Já o incômodo com os conteúdos de terror, que também apareceu fortemente na pesquisa de Ribeiro (2020), parece vir mais do medo que as próprias crianças sentem ao ter contato com vídeos assim. Elas atribuem vídeos de terror serem inapropriados menos a fatores externos, como seus responsáveis não as deixaram assistir, e mais a fatores internos, como o susto que levam ou o medo que sentem:

Eu: Por que [vídeo de terror] não é legal?

João (menino, 9 anos, renda baixa): Porque dá muito susto, eu não consigo dormir à noite!

Davi (menino, 9 anos, renda baixa): Eu até assistia, mas eu assisti tanto, mas tanto, agora tô traumatizado, até tenho hoje crise de traumatizado pelo terror, até hoje...

Eu: Você assistia antes?

Davi: Assistia muuuito, mas muuuito!

Eu: E aí teve algum que te deixou com mais medo, e você parou?

Davi: Parei. Nunca mais assisti.

João fazendo sinal da cruz e rindo: Deus que me livre, rapaz!

Isadora (menina, 10 anos, renda baixa): Tipo, alguns vídeos que algumas pessoas falam, é... Tipo, fazem lendas que, tipo, fazem a gente acreditar que dá medo, mas não dá. Sendo que eles pegam uma máscara daquela pessoa que dá medo pra dar medo nos outros, pra os outros fazerem as pessoas dar like.

Eu: Entendi. Então vídeos desses mais de de terror, que contam histórias, esses não são legais.

Daniel (menino, 8 anos, renda baixa): Ah, tem alguns vídeos que me assusta que falaram sobre o Pateta, aquele homem Pateta.

Isadora: É! Passou no jornal.

Geremias (menino, 9 anos, renda alta): Eu acho que vídeos de 11 anos [não são bons pra idade], não.

Eu: Mas o que você acha que é vídeo de 11 anos, o que que tem no vídeo de 11 anos? Geremias: Por exemplo... Coisa... Que não é da nossa idade. Do mal. Fazendo coisa com a outra pessoa do mal.

Nina (menina, 8 anos, renda alta): Sabe o filme do It: A Coisa? Então, não pode assistir clipe do filme em si porque é muito pesado. Morde o braço da criança... Tem sangue e tudo mais.

Eu: Ah, então vídeo de terror, assim, vocês acham que não é legal pra idade de vcs? Geremias: É!

Eu: Mas tem criança da sala de vocês, da idade de vocês, que vocês conhecem, que gostam de vídeo de terror?

Nina: Eu acho que só mesmo o Leo e o Mateus que um dia quando a gente tava lá no $2^{\circ}$ ano, eles passaram por uma fase que eles não paravam de falar nesse filme, que eles não paravam, aí as crianças tinham pesadelos e eles ficavam falando, aí dava mo medo, porque, ficava... Eles não descansavam um minutinho e eles só falavam disso! 
Importante lembrar que no levantamento realizado, os vídeos de terror foram sinalizados como preferidos por $34 \%$ das crianças da pesquisa. Conforme já explicado, esse é um tipo de vídeo de difícil classificação no YouTube, pois conteúdos diferentes podem ser classificados como sendo ou não de terror. Aqui, as crianças estão usando essa nomenclatura para falar sobre vídeos que de fato as assustam, deixam com medo. Mas reconhecem também que existem conteúdos de mistério ou até mesmo de brincadeiras com elementos de terror que são divertidos, que sabem que são de mentira, como por exemplo as brincadeiras de aproximação-evitação descritas na seção sobre ludicidade. Seriam necessárias mais pesquisas para aprofundar essa discussão.

Para além dos palavrões e vídeos de terror, as crianças também relatam não gostar de desafios/trollagens inadequados (14 citações), conteúdos perigosos (11 citações) e conteúdos violentos (9 citações). Houve também 3 citações sobre clipes de músicas inapropriados, sendo duas referentes a clipes de Funk e uma a clipes de músicas Pop.

Em relação aos desafios inadequados, elas citam exemplos de coisas que os youtubers fazem que não são legais e bem vistas por elas, como relata Isabela:

Isabela (menina, 9 anos, renda alta): Eu via demais! Só que assim, não é que eu goste ou não goste, depende da trollagem! Porque tem trollagem no Minecraft que é "ah, vou destruir a casa dele", mas aí eu acho que não tem muito problema. Mas, tipo, têm uns vídeos de trollagem que... Sei lá! Eu vi gente, tipo, que fez trollagem, a menina começou a chorar por causa da trollagem, que foi uma trollagem muito séria e eu acho que isso não é legal. Eu só gosto de trollagem no jogo mesmo, que não vai afetar nada.

As crianças parecem ter clareza de que existe um limite entre o desafio/trollagem que são brincadeiras divertidas e aqueles que são errados, que colocam as pessoas em posições desconfortáveis, ou até mesmo que incentivam demais o consumo de doce, como ressaltado por Camila, de 8 anos. Além desses conteúdos que consideram inadequados, existem também aqueles que são de fato perigosos, como por exemplo crianças mexendo no fogão, ou desafios onde um jogou limão no rosto do outro. Lulu e Ronaldo expressam sua indignação com tal tipo de conteúdo:

Lulu (menina, 8 anos, renda alta): Eu acho que eles arriscam muito as vidas deles. Ronaldo (menino, 10 anos, renda alta): Só pra ganhar dinheiro! 
Em relação aos conteúdos violentos, as crianças ressaltam principalmente os jogos de tiros, como Free Fire e Fortnite e os noticiários a que seus responsáveis assistem. Sobre os jogos, também houve uma discussão entre Lulu e Ronaldo sobre qual a classificação indicativa de Fortnite e se as crianças poderiam ou não jogar tais jogos:

Ronaldo (menino, 10 anos, renda alta): Eu não gosto de assistir Free Fire, Fortnite... Lulu (menina, 8 anos, renda alta): Eu gosto de Fortnite.

[...]

Eu: E por que você não gosta de Free Fire e Fortnite? Por que você não gosta do jogo?

Ronaldo: Não, eu gosto do jogo, só que também não é pra minha idade, que eu só tenho 10 anos, aí a classificação se eu não me engano é 12 ou 14. [...] E também porque eu não curto muito jogo de tiro.

Lulu: Eu jogo Fortnite, mas Fortnite é a partir de 7 ou 6 anos. Muita criança joga a partir de 7, aí eu jogo também, porque eu tenho 8.

Pesquisando, encontramos que o Ministério da Justiça classificou Fortnite como não recomendado para crianças menores de 12 anos (CLEITON, 2020), como indicado por Ronaldo. Já Lulu usa o argumento de que muitas crianças de 7 anos jogam esse jogo, então por isso ela também poderia jogar.

A única situação em que as crianças sem querer entraram em contato com um conteúdo violento que não queriam assistir foi a relatada por Li e Amanda:

$\mathrm{Li}$ (menina, 10 anos, renda alta): É, tem negócio com violência, tem razão [...] Eu já entrei no YouTube, tinha recomendações, tinha de um cara, tinha um vídeo de um cara que o nome era assim "Batendo em cachorros na rua". Tadinhos!!!

Eu: Tava na recomendação esse vídeo?

Li: É! Mas eu não vi esse tipo de coisa! Tava no início do YouTube, com dois milhões de visualizações!

Amanda (menina, 9 anos, renda alta): Eu já vi um vídeo, eu já vi não, eu parei pra ver só o que ia acontecer, né, porque eu sou curiosa, não sou tipo "ah olhei e não quero ver", eu vou querer ver. Aí eu fui ver e era um menino, né, batendo em um patinho, aí depois que ele bateu, ele assou o pato e comeu.

Li: Sacanagem com o pato! Tadinho!

Esse episódio relatado mostra como não podemos confiar cegamente no algoritmo do YouTube para mostrar vídeos que sejam bons e do nosso interesse, ainda mais quando mais de uma pessoa utiliza a mesma conta ou quando estamos falando de um vídeo que viralizou. No começo do capítulo apontamos para como as crianças confiam naquilo que o YouTube indica, pois de fato na maior parte dos casos, os vídeos que aparecem são relacionados com os vídeos que elas consomem - mas isso não acontece, por exemplo, se a criança entra na plataforma sem uma conta. 
Amanda, no relato abaixo, expressa seu conhecimento de como o YouTube é amplo e pode ser acessado por muita gente ao redor do mundo:

Eu: Você sabe algum tipo de vídeo que você acha que não é legal pra sua idade? Amanda (menina, 9 anos, renda alta): Não. Mas eu sei que tem, porque o YouTube tipo, é um, é um tipo de aplicativo que é mundial, muita gente tem. A maioria do mundo tem YouTube, então ninguém sabe o que vão postar lá.

Ela está se referindo justamente ao YouTube ser uma plataforma que hospeda vídeos de outros usuários, sem produzir seus próprios conteúdos (GILLESPIE, 2017). Apesar disso, Gillespie (2017) aponta que não podemos pensar que a plataforma é neutra nesse processo, pois existe por trás todo um algoritmo para distribuir esse conteúdo postado para algumas pessoas e não a outras, para decidir quando vai entregar tais vídeos, e o que vai ou não permitir ser postado, por exemplo.

Sabendo desses possíveis conteúdos inapropriados para as crianças e dos incômodos que as mesmas sentem tendo contato com eles, é importante se pensar na segurança e bem-estar delas na internet, maximizando as oportunidades e diminuindo o contato com os riscos (LIVINGSTONE, 2009). Nesse sentido, uma educação midiática de qualidade poderia ajudar bastante, para que elas consigam se apropriar do espaço online não apenas de maneira segura, mas também crítica e criativa, como defendido por Buckingham (2019). Uma das formas de apropriação autoral do YouTube é através da possibilidade de expressão por meio dos vídeos, onde as crianças podem compartilhar suas rotinas, interesses e outros aspectos das culturas infantis (TOMAZ, 2017). Será que as crianças têm vontade de ser youtuber? Por quais motivos?

\subsection{5}

\section{"Vocês gostariam de ser youtubers?"}

Por mais que o foco desta pesquisa não sejam os youtuber mirins, não teria como fazer um trabalho pensando nas culturas infantis no YouTube sem trazer essa discussão. Essa foi a última pergunta que fiz na entrevista, após termos discutido todos os aspectos já mencionados. Das 30 crianças participantes, 19 têm vontade de ser youtuber e 8 já tiveram ou dizem ter "mais ou menos" vontade. Apenas 3 crianças expressam que não têm e nunca tiveram vontade de ser youtubers, por se 
considerarem muito tímidas e/ou não saberem o que postar. A timidez é um motivo que aparece também entre as crianças que dizem ter mais ou menos vontade, assim como a falta de habilidade tecnológica para ter um canal - corroborando com os achados de Ribeiro (2020).

Diferentemente da pesquisa de Bezerra (2018), onde todas as crianças entrevistadas queriam ser youtuber e viam isso como algo simples e divertido, as crianças desta pesquisa expressaram bastante conhecimento sobre o quão trabalhoso é ter um canal. Esse é inclusive o motivo mais apontado por elas como impeditivo de serem youtubers, pois consideram algo difícil, que exige tempo e dedicação. Algumas já tentaram ou quiseram ter canais e desistiram, devido a essa dificuldade e falta de retorno:

João (menino, 9 anos, renda baixa): Eu já tive um canal... [...] Meu primeiro vídeo saiu horrivel! E depois eu tirei o canal do YouTube.

Isadora (menina, 10 anos, renda baixa): É porque eu não falo algumas coisas certas, e de vez em quando... Não gosto muito dos meus vídeos... De vez em quando ninguém dá like...

Diego (menino, 10 anos, renda alta): De vez em quando eu falo pra minha mãe que eu quero ser youtuber, e às vezes eu falo que eu não quero.

Eu: Por que que você muda de ideia?

Diego: Porque às vezes eu gosto de ser youtuber pra ganhar dinheiro, e às vezes eu penso que isso vai ser difícil, vai ser complicado de fazer.

Eu: Por que você acha que vai ser complicado?

Diego: Porque às vezes os youtubers precisa ter uma câmera boa...

Camila (menina, 8 anos, renda média): Eu não posto nenhum vídeo por enquanto não, porque eu não eu não sei [...] Eu não sei filmar, porque quando eu abaixo esses aplicativos, tira toda a memória do meu celular à toa, porque eu também não sei gravar vídeo.

Eu: Aham, que aplicativo você baixa? Aplicativo de edição de vídeo?

Camila: Não... Eu não abaixo não, eu peço ajuda pra minha amiga mesmo, que ela já fazia vídeo mesmo. Eu fiz uma dublagem lá, cantando, ficou muito ruim.

As dificuldades das crianças giram em torno de não terem os equipamentos necessários e de não saberem operar com a plataforma do YouTube, o que indica que ter um canal e postar vídeos não é algo tão simples quanto acreditado pelos criadores da plataforma (BURGESS; GREEN, 2018). O YouTube não foi e não é pensado para as crianças, mas, ter em mente que elas estão tendo dificuldades tecnológicas com a plataforma indica que nem sempre elas dominam todas as plataformas. Como defendido por Buckingham (2019), é necessário romper a lógica de que os mais novos são sempre proficientes na internet e melhores que os mais 
velhos, pois isso tira o importante papel dos adultos como mediadores críticos desse processo.

Assim como os grandes canais de youtubers mirins têm responsáveis por trás (TOMAZ, 2017; GIRÃO, 2018; JORGE, 2018; LÓPEZ-VILLAFRANCA et al., 2019), as crianças apontam aqui como a ajuda de adultos seria necessária para conseguirem futuramente ter um canal. Das 19 crianças que desejam ser youtubers, 6 expressam com bastante certeza que terão um canal em algum momento, seja daqui a alguns dias ou daqui a alguns anos. A cultura de pares aqui se mostra como outro grande fator de influência, pois as crianças se referem diversas vezes ao desejo de ter canal como o primo ou o amigo tem. Na conversa abaixo, Miguel expressa sua vontade de ter canal como o primo, para ganhar dinheiro futuramente:

Miguel (menino, 8 anos, renda baixa): Já! Eu vou criar um canal.

Eu: Ah, você vai criar um canal. De quê? Que você vai criar o canal?

Miguel: De jogos.

Eu: De jogos também? A sua mãe já deixou?

Miguel: Ainda... Não sei, se ela vai deixar.

Eu: Mas você já tem esse plano, né?

Miguel: Já.

$\mathrm{Eu}$ E por que que você tem vontade de ser youtuber?

Miguel: Ganhar dinheiro, que nem meu primo.

Eu: $O$ seu primo ganha dinheiro?

Miguel: Ainda não, ele tem... Quantos inscritos, Paulo?

Paulo: Cem!

Miguel: Que cem o quê!

Miguel: Quatorze.

Paulo: Que quatorze!!!

Miguel já participou algumas vezes do canal de seu primo, assim como Daniel, que expressa gravar desafios junto com seu irmão para o canal dele, mostrando como participam ativamente em atividades com seus pares:

Daniel (menino, 8 anos, renda baixa): Não... É... Eu faço sim, eu faço sim [desafios]! Com meu irmão!

Eu: Me fala, quais que você já fez?

Daniel: "O chão é lava"...

Eu: Aham. Você faz pra gravar pro canal dele?

Daniel: Sim, às vezes ele quer gravar.

Eu: Aí você faz com ele? E você acha legal?

Daniel: Sim. "Quem conhece quem"... Eu já fiz assim.

Em geral, os pares que têm canais dos quais as crianças participam são crianças um pouco mais velhas ou adolescentes. Isso nos leva a pensar nessa questão: 
com quantos anos seria ideal criar um canal? Como o intuito aqui é ouvir as opiniões das crianças a respeito, trago o diálogo que tive com Júlia e sua mãe:

Eu: E você, Júlia, já teve vontade de ser youtuber?

Júlia (menina, 10 anos, renda alta): Já!

$\mathrm{Eu}:$ Ainda tem vontade?

Júlia: A minha vida inteira!

Eu: A sua vida inteira?

Júlia: Mas, a mamãe não deixa. E eu concordo.

Eu: Ah, por que que você concorda?

Júlia: Porque eu sou muito pequena e aí pode ser perigoso também.

Eu: Aham, entendi. Por que que você acha que pode ser perigoso?

Júlia: Não sei. As pessoas vão ver quem sou eu. E pode acontecer alguma coisa.

Vira pra mãe e pergunta: Mãe, que que pode acontecer?

[nós três rimos]

$[\ldots]$

Júlia: Ah, não sei, talvez me sequestrar.

$[\ldots]$

Eu: Com quantos anos você acha que tudo bem? Você, Júlia?

Júlia: 14, 15, por aí.

Podemos ver então como Júlia expressa concordar com sua mãe quanto ao momento ideal para criar um canal, apesar de não entender tão bem quais seriam os perigos que a exposição poderia gerar. Li, que também tem muita vontade de ter canal, aponta alguns outros motivos de insegurança listados pela mãe dela:

Li (menina, 10 anos, renda alta): Não pode, não posso. Porque ela disse que pode ter várias coisas: pode me hackear, podem fazer o dinheiro ir pra conta deles, podem me fazer triste com maus comentários...

$\mathrm{Na}$ maioria dos casos, as crianças concordam em esperar um pouco mais para criarem seus canais, com exceção de algumas que demostram pressa para fazê-lo. Sete das trinta crianças entrevistadas têm canais no YouTube, mas apenas uma delas relata postar vídeos com frequência e levar o canal mais a sério. Esse é o caso de Isabela, que possui 2 canais:

Isabela (menina, 9 anos, renda alta): [...] Porque eu via um monte de youtuber fazendo e aí eu quis criar um canal pra mim, pra fazer vídeo, né? Aí eu comecei a fazer, fazer, fazer... E eu tenho dois canais! Eu tenho um que é de gamer e outro que eu leio, né? Que eu conto histórias etc.

[explica o quão trabalhoso é editar vídeo e postar]

Das outras 6 crianças, 4 estão com seus canais sem vídeos ou desatualizados e 2 possuem canais com seus irmãos, mas que também não são tão frequentes nas postagens. Analisando o discurso dessas crianças sobre seus canais, vemos a fluidez 
e percepção do canal como uma brincadeira (DALETHESE, 2017; RIBEIRO, 2020) , algo que não exige um compromisso e que só é feito quando eles sentem vontade - diferentemente de Isabela, que tem um cronograma de postagem, edita seus vídeos, posta também conteúdo no Instagram etc.

Apesar de nas pesquisas de Tomaz (2017) e Dalethese (2017) as crianças terem apontado que gostariam de ser youtubers pelo desejo de fama e reconhecimento entre os pares, neste trabalho apenas uma das crianças citou tal motivação. As outras crianças apresentaram mais fortemente a ideia de ser youtuber por ser "legal" e "divertido". Cinco ainda acrescentaram a possibilidade de ganhar dinheiro como um atrativo a mais da atividade:

Amanda (menina, 9 anos, renda alta): Já tive [vontade se ser youtuber], já tive, porque... Já tive porque eu acho, eu acho, né? Que o YouTube dependendo da quantidade de inscrito ganha bem e eu acho que é meio divertido. Eu acho, eu não sei, eu realmente não sei, eu acho que é divertido, deve ser divertido, gravar [...] Ganhar dinheiro com o que você gosta de fazer.

Gabo (menino, 8 anos, renda baixa): Olha, eu tenho vontade porque eu quero ser rico, e outra... Como eu disse, eu quero dar esperança para as pessoas, a fazerem aquilo - principalmente nessa quarentena - fazerem coisas novas, fazerem brincadeiras que derem pra jogar no chão aqui com seu primo, seu irmão, sua irmã, com sua prima, sua tia, sua mãe, seu pai..

Amanda apresenta aqui a concepção do YouTube como uma atividade que é divertida e ainda dá dinheiro, apesar de reconhecer ao longo da entrevista o quão trabalhosa pode ser. Gabo, que diversas vezes também reconhece a dificuldade da atividade, diz que deseja ser rico, e se encanta com a possibilidade de isso acontecer através da ajuda que ele pode dar a outras pessoas. Ele aponta o aspecto que foi mais levantado pelas crianças: elas querem ser youtubers para mostrarem aspectos lúdicos de suas vidas.

Ao perguntar para as crianças, mesmo aquelas que não têm desejo de ter um canal, quais tipos de vídeos elas gostariam de gravar, tive a surpresa mais uma vez de encontrar uma grande variedade de respostas. $\mathrm{O}$ desejo de ser youtuber para compartilhar jogos como Minecraft, Roblox, Free Fire e Fortnite foi citado 13 vezes ao longo das entrevistas, enquanto fazer desafios e mostrar brincadeiras/brinquedos foi citado 9 e 8 vezes, respectivamente.

Camila (menina, 8 anos, renda média): Vídeo de eu brincando, porque eu tenho tanta imaginação que eu só posto vídeo de brincando! 
Mas, apesar de essas terem sido as temáticas mais citadas, a multiplicidade de conteúdos que as crianças gostariam de compartilhar foi bem maior: elas querem ser youtubers para desenhar, para fazer animação, para gravar $v \log s$, para contar histórias, para dançar, para ensinar receitas, para falar de bandas, para fazer maquiagem, tutoriais, trollagens, para informar e inspirar outras crianças.

Assim, vemos novamente como não podemos reduzir as vontades e motivações das crianças de forma generalizante, pois elas apresentam ideias e concepções ricas, que são únicas - mas que ao mesmo tempo se unem nos aspectos mais característicos das culturas infantis. 


\section{7}

\section{Considerações Finais}

Tendo explorado o lugar do YouTube na sociedade atual e no cotidiano das crianças, pudemos entender melhor quais são os conteúdos preferidos delas e os motivo de eles serem os preferidos, assim como relacionar os sentidos que as crianças atribuem a eles com as culturas infantis. Ficou bastante claro que as crianças assistem ao YouTube para se divertirem, e, por isso, os tipos de vídeos preferidos delas são aqueles com forte carácter lúdico, como os vídeos engraçados, de trollagens, desafios e gameplays. Com exceção dos últimos, que não são tão citados pelas meninas da escola que atende níveis socioeconômicos mais baixos os outros tipos de vídeos parecem agradar crianças independente de gênero e perfil de escola, se configurando como algo compartilhado entre as culturas infantis.

Entretanto, essa unicidade na preferência parece se limitar aos tipos de vídeos preferidos, não se estendendo aos canais, uma vez que as crianças gostam de muitos canais diferentes entre si, rompendo com a ideia de que todas estão assistindo aos mesmos conteúdos na internet. Felipe Neto, o canal mais citado como preferido entre as crianças, foi também o mais criticado durante as entrevistas, mostrando como os sentidos e percepções são negociados e construídos a partir do cotidiano das crianças.

As crianças entrevistadas têm suas próprias contas na plataforma, ou usam as de seus responsáveis, podendo assim se inscrever nos canais de que gostam. Elas demonstram confiar bastante no algoritmo do YouTube, que, em geral, indica vídeos que são exatamente daquele tipo de que elas gostam, e, assim, descobrem novos canais. Conforme apontado anteriormente, o lado bom disso é que os conteúdos inapropriados para a idade ou que desagradam parecem estar mais distantes das crianças do que pensávamos. Por outro lado, o algoritmo está apenas preocupado em fazer com que a criança passe cada vez mais tempo na plataforma, consumindo aqueles conteúdos de forma assídua, o que pode gerar uma dificuldade em saber a hora de parar, caso não haja uma mediação mais próxima dos responsáveis. Tal 
temática é explorada bem no documentário "O Dilema das Redes" (2020), embora o tom da trama seja bastante alarmista.

Apesar de as crianças não entenderem - assim como muitos adultos - o funcionamento e as intenções por trás das grandes empresas, elas aprendem com seus pares, familiares e com os próprios youtubers um pouco de como a plataforma funciona. A maioria delas sabe que os youtubers ganham (muito) dinheiro, por meio dos anúncios que são exibidos e das métricas dos vídeos. Porém, sabem também que isso exige bastante trabalho, e que apenas os youtubers grandes conseguem ficar ricos com o YouTube. Esse tipo de conhecimento demonstra um conhecimento razoável da plataforma, mas não elimina a necessidade de que haja mediação por parte de nós, adultos, para que elas possam se apropriar de uma forma ainda mais crítica e criativa das mídias.

Pudemos constatar nessa pesquisa que as culturas infantis estão fortemente presentes tanto nos conteúdos a que as crianças assistem quanto na forma com que elas se apropriam desses conteúdos. Dentre os 4 eixos estabelecidos por Sarmento (2003a), 3 deles se mostraram mais fortemente presentes, sendo eles: a ludicidade, a interatividade e a reiteração.

Em relação à ludicidade, primeiramente, os conteúdos assistidos são classificados como divertidos, interessantes e engraçados pelas crianças. As culturas lúdicas e brincadeiras infantis clássicas estão presentes em muitos vídeos, mas em formatos diferentes. As crianças querem brincar daquele jeito em suas casas, mas muitas vezes não podem ou não conseguem, então elas reinterpretam e dão significados novos àquelas práticas. Elas dizem que assistem ao YouTube para se divertirem, não para aprenderem. Porém, quando veem que o aprendizado do YouTube pode também ser válido, citam que descobrem curiosidades e informações, que aprendem a jogar, a se maquiar, a desenhar, a fazer slime etc.

A interatividade nas práticas do YouTube pode ser dividida na interação com os responsáveis, com os youtubers e com seus pares. Em relação aos responsáveis, as crianças, em geral, gostariam que eles estivessem mais presentes em suas práticas do YouTube, seja assistindo mais aos vídeos com elas ou até mesmo realizando brincadeiras vistas na tela. É frequente os adultos reclamarem dos vídeos e/ou youtubers a que as crianças assistem, mas elas muitas vezes argumentam e querem saber o porquê dessa reclamação, buscando ver se concordam com ela ou não. Já a interação com youtubers em si assume significados muito únicos para cada criança. 
Novamente, elas interagem quando veem sentido naquilo, quando gostam do conteúdo ou quando acham que fará alguma diferença.

A cultura de pares permeia fortemente toda a discussão sobre YouTube. As crianças se referem às amizades com muito carinho, expressando, inclusive, a saudade que sentem em tempos de quarentena. Elas compartilham seus gostos com alguns de seus pares e trocam recomendações de vídeos, mas, em geral, apesar de gostarem de tipos de vídeos semelhantes, têm suas preferências específicas de canais. Entendem claramente que meninos e meninas podem assistir a quaisquer vídeos no YouTube, mas sabem que há uma diferença nas preferências entre os gêneros.

Assim, as crianças constroem suas preferências únicas, elegendo poucos canais favoritos de que gostam muito mais do que outros. Esse é o primeiro traço da reiteração, mostrando que no plano sincrônico, elas repetem e recriam suas rotinas no YouTube a partir desses canais preferidos por elas. Já no plano diacrônico, que se refere à transmissão de brincadeiras e rotinas vivenciadas e repassadas a cada geração, vemos que as crianças enxergam os youtubers como muito diferentes delas, pois a rotina se diferencia e eles são, segundo as palavras delas, "muito ricos". Apesar de as crianças saberem que a maioria dos youtubers a que assistem não são crianças, elas relatam que eles também não são adultos, pois brincam e se divertem. Dessa forma, o que talvez os aproxime e faça com que haja uma certa cultura compartilhada seja o fato de eles também brincarem de atividades do gosto e de interesse das crianças.

As crianças veem os youtubers preferidos como bons exemplos quando eles não fazem nada de errado, mas não trazem um tom forte de admiração por isso em suas falas. Elas alertam quanto aos youtubers que fazem "coisas erradas", ou que são pessoas diferentes fora das câmeras, entendendo que quando isso acontece, o melhor é não assistir a tal conteúdo. A maior preocupação das crianças parece serem os palavrões e os vídeos assustadores ou de terror. O palavrão tem um tom mais social na crítica, por ser considerado "feio" para a idade, enquanto o terror é algo mais pessoal, por deixá-las assustadas e/ou com medo. Também reconhecem conteúdos perigosos e violentos como ruins, mas dificilmente acessam esses sem querer.

A maioria das crianças entrevistadas relataram querer ser youtubers, mas sabem o quão trabalhoso isso pode ser, então, optam por esperar alguns anos ou 
recorrem aos pares e/ou responsáveis para as ajudarem. É um desejo fluido por grande parte das crianças, que pode ir e vir, se configurando mais como uma grande brincadeira (DALETHESE, 2017) ou sonho de profissão futura.

Assim sendo, esta pesquisa contribuiu, academicamente, para ampliar os estudos que tratam da discussão das infâncias no YouTube, algo que ainda é pouco explorado na literatura. A partir de uma metodologia quantitativa e qualitativa, foi possível tanto ver as preferências gerais das crianças dessa faixa etária quanto investigar mais a fundo suas motivações, práticas e sentidos atribuídos à plataforma. Um grande diferencial foi ter conseguido uma amostra que contemplasse bastante as crianças de níveis socioeconômicos menos favorecidos da sociedade, o que muitas vezes é deixado de lado nas pesquisas envolvendo tecnologia.

Apesar disso, principalmente devido à pandemia, a metodologia quantitativa foi afetada por ter que se readaptar ao novo contexto, não podendo assim ter uma amostra tão equilibrada e equitativa quanto era desejado. Futuras pesquisas são necessárias para construir amostras mais representativas, possibilitando, assim, testes estatísticos com análises que contemplem outras variáveis e que sejam realizadas de forma mais profunda e abrangente. Ademais, seria imprescindível realizar pesquisas de larga escala para vermos diferenças regionais, sociais e etárias entre as preferências das crianças.

Ainda assim, os achados desta pesquisa trazem uma contribuição relevante para a temática, não apenas academicamente, mas também em termos práticos e sociais. Pensar nos conteúdos preferidos das crianças e entender os motivos de eles serem tão adorados nos possibilita construir materiais audiovisuais que interessem às crianças levando em consideração essas especificidades. Acreditamos que os próprios youtubers poderiam se beneficiar de tais informações, não pensando somente no aumento de lucro, mas focando naquilo que é importante para as crianças e ouvindo suas reclamações sobre os palavrões ou pedidos para classificação etária nos vídeos, por exemplo. Talvez trazer mais brincadeiras que as crianças possam de fato realizar em casa, sem a necessidade de materiais caros. Podem também aproveitar a atenção das crianças para serem bons exemplos, ou até mesmo trazerem mais conteúdos educativos, mas sem perder o carácter lúdico de que elas tanto gostam. A possibilidade de ter pedagogos nas equipes de produção desses grandes canais seria importantíssimo para que o que os conteúdos continuem agradando e divertindo as crianças, mas que também respeitem e preservem suas infâncias. 
Reafirmamos também, em termos sociais, o quanto as crianças não apenas reproduzem aquilo que veem, mas reinterpretam, dão novos significados, usam todo seu repertório cultural e social para atribuírem novos sentidos àquilo. Longe de serem espectadores passivos, elas criam hipóteses ricas sobre o que estão vendo, tentando entender o que está por trás das telas e criticando quando não concordam com algo.

Assim, a presente pesquisa possibilitou ouvir as crianças de forma profunda sobre um tema de que elas tanto gostam de falar. As crianças abriam um grande sorriso ao terem espaço para falar sobre os vídeos ou youtubers favoritos, e sorriam mais ainda de surpresa quando descobriam que eu conhecia os conteúdos a que elas se referiam. Isso demonstra a importância de irmos para além das críticas e proibições para entendermos algo que é tão caro para as crianças. Precisamos entender seus gostos, seus motivos, suas preferências, para então pensarmos em como tornar essa vivência ainda mais segura e proveitosa para elas. Tratar as crianças como indefesas e manipuláveis apenas tira delas o protagonismo e a agência tão defendidos por nós, assim como excluí-las totalmente do espaço online acarreta em mais um lugar na sociedade onde elas não seriam bem-vindas. E a realidade é que muitas delas, atualmente, estão fortemente presentes nesse espaço. Então, o que fazer?

De fato, existem questões seríssimas a serem discutidas e resolvidas, como a responsabilização pelos dados coletados das crianças, a publicidade exacerbada e os conteúdos inapropriados. Precisamos pressionar diversas instâncias para que as crianças estejam protegidas na rede, e suas infâncias sejam respeitadas. A mediação parental é essencial nesse processo, mas, entendemos aqui que uma criança não é responsabilidade apenas de seus familiares, então, lutamos para que outras instâncias como o Estado, as empresas e a escola também assumam tais compromissos. Especificamente sobre a escola, defendemos que seja obrigatória no país a educação midiática para todas as crianças, onde elas possam ter um espaço seguro, com especialistas na área, para discutirem sobre tais conteúdos, aprenderem formas de se proteger, saberem mais a fundo como funcionam as mídias, seus riscos e potencialidades.

O YouTube se mostrou como um lugar extremamente rico para pensarmos nas infâncias atuais, que, por mais que tenham suas especificidades, não se afastam tanto dos eixos centrais das culturas infantis. O lúdico é ainda o que as crianças têm de mais importante em suas vidas, e elas desejam compartilhar isso com seus pares 
e outros adultos. A infância não está sumindo ou sendo destruída, pois as crianças, por mais que ainda precisem de muita proteção, estão se apropriando de formas únicas e autorais de cada lugar por onde passam, levando um pouco consigo de tudo aquilo que gerações passadas também vivenciaram. Assim, as culturas infantis permanecem vivas, mesmo sendo ressignificadas a todo tempo. 


\section{8}

\section{Referências Bibliográficas}

ANDRADE, P. D. de; COSTA, M. V. Nos Rastros Do Conceito De Pedagogias Culturais: Invenção, Disseminação E Usos. Educação em Revista, v. 33, n. 0, 2017.

ARAN-RAMSPOTT, S.; FEDELE, M.; TARRAGÓ, A. Funciones sociales de los youtubers y su influencia en la preadolescencia. Comunicar, v. 26, n. 57, p. 71-79, 2018. Disponível em: <https://www.scopus.com/inward/record.uri?eid=2-s2.0$85053775047 \&$ doi $=10.3916 \% 2$ FC57-201807\&partnerID=40\&md5=41139458f885b8a21 ae0b827d6e05457> .

ARAÚJO, D. K. C. Entre "likes" e postagens: conteúdos acessados e veiculados no YouTube por crianças do $4^{\circ}$ ano dos anos iniciais do ensino fundamental. 2019. 68 p. Monografia (Graduação) UFPB/CE/Pedagogia.

ARIÈS, P. A descoberta da infância. In: História Social da Criança e da Família. Rio de Janeiro: Guanabara, 1981a. p. 50-68.

ARIÈS, P. Os Dois Sentimentos da Infancia. In: História Social da Criança e da Família. Rio de Janeiro: Guanabara, 1981b. p. 156-164.

AZEVEDO, R. Free Fire vs Fortnite: saiba qual o Battle Royale ideal para você - Liga dos Games. Disponível em: <https://www.ligadosgames.com/free-fire-vsfortnite/>. Acesso em: 14 nov. 2020.

BANDURA, A. Social Learning Theory of Aggression. Journal of communication, n. 28, p. 12-29, 1978. Disponível em: <https://www.learningtheories.com/social-learning-theory-bandura.html>.

BAUER, M. W.; GASKELL, G. Pesquisa qualitativa com texto, imagem e som: um manual prático. 7. ed. Petrópolis: Vozes, 2008. p. 615.

Becker, B. Brincando na web: Descrição e análise das atividades lúdicas desempenhadas por crianças de 5 a 12 anos na internet. 2013. 130p. (Dissertação de Mestrado). Instituto de Psicologia, Universidade Federal da Bahia, Salvador, BA.

Becker, B. Infância, tecnologia e ludicidade: a visão das crianças sobre as apropriações criativas das tecnologias digitais e o estabelecimento de uma nova cultura lúdica. 2017. 288p. Tese de Doutorado. Instituto de Psicologia, 
Universidade Federal da Bahia, Salvador, BA.

BENN, J. F. Crianças youtubers e suas produções culturais. 2019. 94 p. Monografia (Graduação) Universidade de Brasília.

BEZERRA, L. D. G. L. D. C. A influência dos youtubers no universo infantil. 2018. 82p. Dissertação de Mestrado. Programa de Mestrado Profissional em Administração. Universidade de Fortaleza.

BRAGAGLIA, A. P.; FERREIRA, A. L. do N. Os youtubers mirins e a felicidade através do consumo. Temática, v. 12, n. 12, p. 57-73, 2016.

BRAUN, V.; CLARKE, V. Using thematic analysis in psychology. Qualitative Research in Psychology, v. 3, n. 2, p. 77-101, jan. 2006. Disponível em: <http://www.tandfonline.com/doi/abs/10.1191/1478088706qp063oa>.

BROUGÈRE, G. A criança e a cultura lúdica. Revista da Faculdade de Educação, v. 24, n. 2, p. 103-116, jul. 1998. Disponível em: $<$ http://www.scielo.br/scielo.php?script=sci_arttext\&pid=S0102$25551998000200007 \& \operatorname{lng}=\mathrm{pt} \& \operatorname{lng}=\mathrm{pt}>$.

BUCKINGHAM, D. Cultura Digital, Educação Midiática e o Lugar da Escolarização. Educação \& Realidade, v. 35, n. 3, p. 37-58, 2010.

BUCKINGHAM, D. The Media Education Manifesto. 1. ed. Cambridge: Polity Press, 2019.

BURGESS, Jean; GREEN, Joshua. YouTube e a revolução digital. São Paulo: Aleph. 2009.

BURGESS, J.; GREEN, J. YouTube: Online Video and Participatory Culture. 2. ed. Cambridge: Polity Press, 2018.

CETIC.BR. TIC Kids Online Brasil 2019. [s.l: s.n.]. Disponível em: <https://cetic.br/pesquisa/kids-online/publicacoes/>. Acesso em: 4 dez. 2020.

CHAU, C. YouTube as a participatory culture. New Directions for Youth Development, v. 2010, n. 128, p. 65-74, dez. 2010. Disponível em: <http://doi.wiley.com/10.1002/yd.376>.

CHICO, F. Como Luccas Neto, que ofendia crianças, virou a Xuxa da internet - Disponível em: <https://www1.folha.uol.com.br/ilustrissima/2019/05/comoluccas-neto-que-ofendia-criancas-virou-a-xuxa-da-internet.shtml>. Acesso em: 4 dez. 2020.

CLEITON, M. Qual é a idade mínima para jogar Fortnite? Entenda classificação. Disponível em: $<$ https://www.techtudo.com.br/noticias/2020/02/qual-e-a-idade-minima-parajogar-fortnite-entenda-classificacao-esports.ghtml>. Acesso em: 6 dez. 2020.

Corrêa, L. Geração Minecraft: uma abordagem cultural sobre o consumo de vídeos por crianças no YouTube Brasil [Resumo]. In Escola Superior de Propaganda e 
Marketing (Eds.), Resumos de grupos de trabalho, V Encontro dos GTs de PósGraduação. São Paulo, Brasil. 2015.

Corrêa, L. Geração YouTube: Um mapeamento sobre o consumo e a produção de vídeos por crianças de 0 a 12 anos - Brasil - 2005/2016. São Paulo: ESPM Media Lab. 2016.

CORSARO, William A. A reprodução interpretativa no brincar ao "faz-de-conta" das crianças. Educação, sociedade e culturas, v. 17, p. 113-134, 2002.

CORSARO, William A. The sociology of childhood. Sage publications, 2017.

CORSARO, William A. We're friends, right?: Inside kids' culture. Joseph Henry Press, 2003.

CORSARO, W. A. Reprodução Interpretativa e Cultura de Pares. In: MÜLLER, F.; CARVALHO, A. M. A. (Ed.). Teoria e prática na pesquisa com crianças: diálogos com William Corsaro. São Paulo: Cortez, 2009a. p. 213.

CORSARO, W. A. Interpretative Theory. ENCYCLOPEDIA OF THE LIFE COURSE AND HUMAN DEVELOPMENT, p. 271-274, 2009b.

CORSARO, W.; DONNA, E. Children'S Peer Cultures. Annual Review of Sociology, v. 16, n. 1, p. 197-220, 1990.

COSTA, M. V.; DE ANDRADE, P. D. Na produtiva confluência entre educação e comunicação, as pedagogias culturais contemporâneas. Perspectiva, v. 33, n. 2, p. 843, 2016.

CRESWELL, John W. Projeto de pesquisa métodos qualitativo, quantitativo e misto. In: Projeto de pesquisa métodos qualitativo, quantitativo e misto. 2010. p. 296-296.

CRIANÇA, a alma do negócio. Direção: Estela Renner. São Paulo: Maria Farinha Produções. 1 vídeo (49 min). Disponível em: https://www.youtube.com/watch?v=ur91If4RaZ4. Acesso em: 1 jan. 2021.

DALETHESE, T. R. Faz de conta que todos nós somos youtubers: crianças e narrativas contemporâneas. Dissertação de Mestrado, 173 p. Universidade Federal do Rio de Janeiro, Rio de Janeiro, 2017.

DOMINGUES-MONTANARI, S. Clinical and psychological effects of excessive screen time on children. Journal of Paediatrics and Child Health, v. 53, n. 4, p. 333-338, 2017.

DUARTE, R. Entrevistas em pesquisas qualitativas. Educar em Revista, n. 24, p. 213-225, dez. $2004 . \quad$ Disponível em: <http://www.scielo.br/scielo.php?script=sci_arttext\&pid=S010440602004000200011\&lng=pt\&tlng=pt>.

DUARTE, R.; LEITE, C.; MIGLIORA, R. Crianças e televisão: o que elas pensam sobre o que aprendem com a tevê. Revista Brasileira de Educação, v. 11, n. 33, 
p. 497-510, 2007.

ECO, U. Apocalípticos e Integrados. 7. ed. [s.1.] LUMEN, 1984.

ELLSWORTH, E. Modos de endereçamento: uma coisa de cinema; uma coisa de educação também. In: SILVA, T. T. DA (Ed.). Nunca fomos humanos: nos rastros do sujeito. 1. ed. Belo Horizonte: Autêntica Editora, 2001. 7p. 208.

ELLSWORTH, E. Places of learning: Media, architecture, pedagogy. New York: Routledge, 2005.

Features impacted by COPPA: Made for Kids content - YouTube. Disponível em: 〈https://www.youtube.com/watch?v=0CzTAeLNRbg>. Acesso em: 26 maio. 2020 .

FERREIRA. A. L. N. Infância no tubo digital: felicidade via consumo? Dissertação, 166 p. Mestrado em Mídia e Cotidiano - Universidade Federal Fluminense, Niterói, 2016.

FISCHER, R. M. B. O estatuto pedagógico da mídia: questões de análise. Educação e Realidade, v. 22, n. 2, p. 59-80, 1997.

FREIRE, J. L. Produzir comunicação na cibercultura: coisa de criança! Tese de Doutorado, 152 p. Centro de Educação e Humanidades - Faculdade de Educação, Universidade do Estado do Rio de Janeiro, Rio de Janeiro, 2016

FUENZALIDA, V. LA INFLUENCIA CULTURAL DE LA TELEVISIÓN. Revista Diálogos de la Comunicación, v. 17, n. May, p. 9, 1987. Disponível em: <http://fedvirtual2.fed.uh.cu/dataedu/7/Lecturas_recomendadas_4/fuenzalida.pdf>

FUENZALIDA, V. Motivaciones infantiles ante la TV. Revista Latinoamericana de Comunicación, n. 51, 1995.

FUENZALIDA, V. Violencia y TV infantil. Revista Latinoamericana de Comunicación, n. 53, 1996.

FUENZALIDA, V. Motivaciones de los niños hacia la TV: una mirada desde la recepción. PENSAMIENTO EDUCATIVO, 1997. Disponível em: <http://biblioteca.uahurtado.cl/ujah/reduc/pdf/pdf/7439.PDF>.

FUENZALIDA, V. Cambios en la relación de los niños con la televisión. Comunicar, v. 15, n. 30, p. 49-54, 2008.

FUENZALIDA, V. Resignificar la educación televisiva: Desde la escuela a la vida cotidiana. Comunicar, v. 18, n. 36, p. 15-24, 2011.

GATTI, B. A. Estudos quantitativos em educação. Educação e Pesquisa, v. 30, n. 1, p. 11-30, 2004.

GIBBS, G. Análise de dados qualitativos: coleção pesquisa qualitativa. Porto Alegre: Artmed, 2009. 
GILLESPIE, T. Governance of and by platforms. SAGE Handbook of Social Media, p. forthcoming, 2017.

GIRÃO, L. V. O. Crianças nas mídias digitais: os usos e apropriações de crianças brasileiras no YouTube Brasil. 40 p. Trabalho de Conclusão de Curso (Graduação). Curso de Psicologia Social. Universidade Federal do Ceará, Sobral, 2018

GIROUX, H. Doing Cultural Studies: Youth and the Challenge of Pedagogy. Harvard Educational Review, v. 64, n. 3, p. 278-309, set. 1994. Disponível em: <http://hepgjournals.org/doi/10.17763/haer.64.3.u27566k67qq70564>.

GIROUX, H. The Mouse that Roared Disney and the End of the Innocence. New York: ROWMAN \& LITTLEFIELD, 1999.

GOMES, H. S. YouTube muda para proteger crianças, tira receita de youtubers e afeta geral; entenda o que rolou. Disponível em: $<$ https://www.uol.com.br/tilt/reportagens-especiais/as-novas-regras-doyoutube/\#cover>. Acesso em: 20 out. 2020.

GUNTER, B.; MCALEER, J. Children and Television. 2. ed. New York: Taylor \& Francis e-Library, 1997.

HOME, Anna et al. The children's television charter. Metro Education, n. 5, p. 19, 1995.

Introducing the newest member of our family, the YouTube Kids app. Disponível em: <https://youtube.googleblog.com/2015/02/youtube-kids.html>. Acesso em: 6 jun. 2020.

JAMES, A.; PROUT, A. Constructing and Reconstructing Childhood. 2. ed. [s.l.] Taylor \& Francis e-Library, 2005.

JENKINS, H. Convergence Culture: Where Old and New Media Collide. 1. ed. [s.l.] NYU Press, 2006.

JENKINS, H. Cultura da convergência. Aleph, 2015.

JORGE, G. M. dos S. De criança para criança: discursos sobre gênero, raça e classe social produzidos por youtubers mirins. In: Congresso Internacional de Educação e Tecnlogias, Anais... 2018.

KARSTEN, L. Children's use of public space: The gendered world of the playground. Childhood, v. 10, n. 4, p. 457-473, 2003.

KINAST, P. Fortnite vs Free Fire: Quais as diferenças entre esses dois jogos Battle Royale? Disponível em: <https://www.oficinadanet.com.br/games/24504fortnite-vs-free-fire-as-diferencas-em-dois-dos-battle-royale-para-celular $>$. Acesso em: 14 nov. 2020.

LANGE, P. G. Kids on youtube: technical identities and digital literacies. Walnut Creek: Left Coast Press, 2014. 
LAVADO, T. Uso da internet no Brasil cresce, e $70 \%$ da população está conectada. Disponível em: $<$ https://g1.globo.com/economia/tecnologia/noticia/2019/08/28/uso-da-internetno-brasil-cresce-e-70percent-da-populacao-esta-conectada.ghtml >. Acesso em: 22 nov. 2019.

LEÃO, D.; PRESSLER, N. Youtuber Mirim e o Consumo Infantil. In: $40^{\circ}$ Congresso Brasileiro de Ciências da Comunicação, Anais...2017.

LEMES, B. M.; LOPES, T. A. C.; RABAIOLLI, J. Youtubers Mirins e Publicidade Infantil: Uma Análise do Vídeo "Baby Alive: Novos Acessórios Oficiais" de Julia Silva. In: XVIII Congresso de Ciências da Comunicação na Região Sul, Santa Maria. Anais... Santa Maria: Intercom - Sociedade Brasileira de Estudos Interdisciplinares da Comunicação, 2017.

LISAUSKAS, R. Não adianta a luta diária para educar os nossos filhos se eles assistirem ao Felipe Neto. Disponível em: $<$ https://emais.estadao.com.br/blogs/ser-mae/nao-adianta-a-luta-diaria-paraeducar-os-nossos-filhos-se-eles-assistirem-ao-felipe-neto/>. Acesso em: $5 \mathrm{dez}$. 2020.

LIVINGSTONE, S. A Rationale for Positive Online Content for Children. Communication Research Trends, v. 28, n. 3, p. 12-17, 2009. Disponível em: <http://ehis.ebscohost.com.nukweb.nuk.uni-lj.si/ehost/detail?sid=f2d634f8-5f9b47d6-baa7-

7ad99d7f0664\%40sessionmgr115\&vid=1\&hid=115\&bdata=Jmxhbmc9c2wmc2N vcGU9c210ZQ\%3D\%3D\#db=ufh\&AN=44451879>.

LIVINGSTONE, S. et al. In their own words: What bothers children online? European Journal of Communication, v. 29, n. 3, p. 271-288, 2014.

LIVINGSTONE, S. et al. Is there a ladder of children's online participation? Findings from three Global Kids Online countries. Innocenti Research Brief 201902, 2019. Disponível em: <https://www.unicef-irc.org/publications/pdf/IRB_201902 13-2-19.pdf>.

LIVINGSTONE, S. Erasmus Medal Lecture 2018 AE GM Barcelona: Realizing Children's Rights in Relation to the Digital Environment. European Review, p. 114, 23 abr. 2020. Disponível em: <https://www.cambridge.org/core/product/identifier/S106279872000054X/type/jo urnal_article>.

LÓPEZ-VILLAFRANCA, P. et al. Menores en YouTube, ¿ocio o negocio? Análisis de casos en España y EUA. El profesional de la información, v. 28, n. 5, p. 1-13, 2019.

LUZ. M. DA. D. Tudo o que uma criança quer fazer, mas não pode, ele faz: problematizações sobre um canal do YouTube à luz das pedagogias culturais. 46 p. Trabalho de Conclusão de Curso (Graduação). Pedagogia. Universidade Federal de Santa Catarina. Santa Catarina, 2018.

MAIDEL, S.; VIEIRA, M. L. Mediação parental do uso da internet pelas crianças. 
Psicologia em Revista, v. 21, n. 2, p. 292, 2016.

MALACARNE, J. 'Mães contra Felipe Neto': entenda a polêmica que se tornou um dos assuntos mais comentados nas redes sociais. Disponível em: $<$ https://revistacrescer.globo.com/Criancas/Comportamento/noticia/2020/07/maes -contra-felipe-neto-entenda-polemica-que-se-tornou-um-dos-assuntos-maiscomentados-nas-redes-sociais.html>. Acesso em: 11 nov. 2020.

MARÔPO, L.; SAMPAIO, I. V.; MIRANDA, N. P. de. Meninas no YouTube: participação, celebrização e cultura do consumo. Estudos em Comunicação, v. 1, n. 26, p. 175-195, 2018.

MARTIN, C. L. Attitudes and expectations about children with nontraditional and traditional gender roles. Sex Roles, v. 22, n. 3-4, p. 151-166, 1990.

MATTOS, L. Youtubers 'deseducam' crianças com 'trollagens' e palavrões |. Disponível em: <https://www.otempo.com.br/interessa/comportamento/youtubersdeseducam-criancas-com-trollagens-e-palavroes-1.1608125>. Acesso em: 24 set. 2019.

MCROBERTS, S. et al. "Do it for the viewers!" Audience engagement behaviors of young YouTubers. In: Proceedings of IDC 2016 - The 15th International Conference on Interaction Design and Children, Anais...2016.

MELO, D. R. De; GUIZZO, B. S. Infância YouTuber: problematizando representações de crianças inseridas na cultura de sucesso. Série-Estudos Periódico do Programa de Pós-Graduação em Educação da UCDB, v. 24, n. 50, p. 121, 10 abr. 2019. Disponível em: <http://www.serieestudos.ucdb.br/index.php/serie-estudos/article/view/1162>.

MONTEIRO, M. C. S. APROPRIAÇÃO POR CRIANÇAS DA PUBLICIDADE EM CANAIS DE YOUTUBERS BRASILEIROS: a promoção do consumo no YouTube através da Publicidade de Experiência. Tese de Doutorado. 333 p. Programa de Pós-Graduação em Comunicação e Informação da Universidade Federal do Rio Grande do Sul. Porto Alegre, 2018.

MORAES, H. J. P. Os youtubers e as relações de identificação e projeção no imaginário infanto-juvenil contemporâneo: discussões a partir da ética da estética. Iluminuras, v. 18, n. 44, p. 182-196, 2017. Disponível em: <http://www.seer.ufrgs.br/index.php/iluminuras/article/view/75740/43145>.

NOGUEIRA, J. C. "Sites de Obaid": o que incomoda as crianças na internet. 95 p. Dissertação de Mestrado. Departamento de Educação, Pontifícia Universidade Católica do Rio de Janeiro. Rio de Janeiro, 2016.

O DILEMA das Redes. Direção: Jeff Orlowski. Estados Unidos: Netflix, 2020. 1 vídeo (94 min). Disponível em www.netflix.com. Acesso em: 1 jan. 2021.

OLIVEIRA, J. D. S. Comunicação, consumo e infância na era das mídias on-line: uma análise sobre a publicidade infantil nos vídeos da youtuber mirim Julia Silva. 144 p. Dissertação de Mestrado. - Escola de Comunicação, Educação e Humanidades da Universidade Metodista de São Paulo, São Bernardo do Campo, 
2018.

OLIVEIRA, R. A. D. C. Lugar de criança é no YouTube? Práticas discursivas dos novos formatos da publicidade infantil no canal de Julia Silva. 147 p. Dissertação de Mestrado. Programa de Pós- Graduação em Psicologia da Universidade Federal do Ceará. Fortaleza, 2019.

OROZCO-GÓMEZ, G. La audiencia frente a la pantalla. Una exporacion del proceso de recepcion televisiva. Dialogos de la comunicación, p. 27-42, 1991. Disponível em: <http://teoriacom.files.wordpress.com/2008/08/04-guillermoorozco.pdf>.

PACETE, L. G. Quem são os usuários do YouTube no Brasil? Disponível em: <https://www.meioemensagem.com.br/home/midia/2017/07/24/quem-sao-osusuarios-do-youtube-no-brasil.html>. Acesso em: 10 set. 2019.

PAPINI, A. B. A publicidade infantil em canais de YouTubers mirins. $91 \mathrm{p}$. Dissertação de Mestrado. Programa de Mestrado em Comunicação. Faculdade Cásper Líbero. São Paulo, 2016.

PINHEIRO, B. Felipe Neto mostra mudanças de posicionamento: "Errei muito no passado". Disponível em: <https://www.diario24horas.com.br/noticia/52925felipe-neto-mostra-mudancas-de-posicionamento-errei-muito-no-passado->.

Acesso em: 11 nov. 2020.

PINTO, M. A infância como construção social. In: PINTO, M.; SARMENTO, M. J. (Ed.). As crianças: contextos e identidades. Braga: Bezerra Editora, 1999.

POSTMAN, N. O desaparecimento da infância. [s.1.] Graphia, 2006.

PRIVACIDADE Hackeada. Direção: Karim Amer, Jehane Noujaim. Estados Unidos: Netflix, 2019. 1 vídeo (112 min) Disponível em: www.netflix.com. Acesso em: 1 jan. 2021.

RANGEL, J. G. O estudo da violência na televisão. Trabalho apresentado ao NP 01 - Teorias da Comunicação, do IV Encontro dos Núcleos de Pesquisa do XXVII Congresso Brasileiro de Ciências da Comunicação. Rio de Janeiro, 2004.

RENÉS ARELLANO, P.; GOZÁLVEZ PÉREZ, V.; BERLANGA FERNÁNDEZ, I. YouTube e influencers en la infancia. Análisis de contenidos y propuestas educativas. ICONO, v. 18, n. 2, p. 269-295, 1 jul. 2020. Disponível em: <https://icono14.net/ojs/index.php/icono14/article/view/1455>.

RIBEIRO, A. L. F. Quem não conhece o YouTube? Uma perspectiva participativa das práticas de crianças em plataforma de vídeos online. 135p. Dissertação de Mestrado. Programa de Pós Graduação em Psicologia) - Instituto de Psicologia, Universidade Federal da Bahia. Salvador, 2020.

SANTOS, J. N. Infância negra e mídias digitais: uma análise de canais do YouTube realizados por meninas negras. Tese de Doutorado. 212 p. Programa de Pós- Graduação em Educação da Universidade Federal de São Carlos. São Carlos, 2018. 
SARMENTO, M.; BARRA, S. Os saberes das crianças e as interações na rede. Zero-a-Seis, $2008 . \quad$ Disponível em: $<$ https://periodicos.ufsc.br/index.php/zeroseis/article/view/1776/>.

SARMENTO, M. J.As culturas da infância nas encruzilhadas da $2^{\mathrm{a}}$ modernidade. In M. J. Sarmento e A. B. Cerisara (Orgs.), Crianças e miúdos. Perspectivas sóciopedagógicas da Infância e Educação. Porto: ASA. 2003a.

SARMENTO, M. J. Imaginário e culturas da infância. Cadernos de Educação, v. 12, n. 21, p. 51-69, 2003 b.

SARMENTO, M. J.; PINTO, M. As crianças e a infância: Definindo conceitos, delimitando o campo. As crianças: contextos e identidades., p. 7-30, 1997.

SATLER, L. L.; CARRIJO, A. J. Infância e YouTube: a recepção infantil de narrativas audiovisuais digitais. Geminis, v. 10, n. 1, p. 49-70, 2019.

SCIENTIFIC SOFTWARE DEVELOPMENT GMBH. ATLAS.ti, 2002. .

\begin{abstract}
SILVA, A. C. Felipe Neto reafirma promessa contra vídeos impróprios e explica os antigos. Disponível em: $<$ https://tvefamosos.uol.com.br/noticias/redacao/2020/06/29/felipe-neto-reafirmapromessa-contra-videos-improprios-e-explica-os-antigos.htm>. Acesso em: $5 \mathrm{dez}$. 2020.
\end{abstract}

SILVA, T. T. da. Documentos de Identidade: Uma introdução às teorias do currículo. 2. ed. Belo Horizonte: Autêntica Editora, 2005.

SILVA, T. T. DA. "Sim pra tudo" - O que vídeos em canais infantis do youtube podem ensinar às crianças?. Trabalho de Conclusão de Curso (Graduação). 37 p. Curso de Pedagogia. Universidade Federal de Santa Catarina. Florianópolis, 2019

SOCIAL BLADE. Top 250 YouTubers Channels in Brazil - Socialblade YouTube Stats | YouTube Statistics. Disponível em: $<$ https://socialblade.com/youtube/top/country/br/mostsubscribed>. Acesso em: 9 dez. 2020.

STEINBERG, S. R. KINDERCULTURE: The Corporate Construction of Childhood. 3. ed. Boulder: Westview Press, 2011.

TOMAZ, R. O que você vai ser antes de crescer? Youtubers, infância e celebridade. Tese de Doutorado. 232 p. Programa de Pós Graduação em Comunicação e Cultura. Universidade Federal do Rio de Janeiro, Escola de Comunicação. Rio de Janeiro, 2017.

TOMÉ, H. L.; BORGES, G. A infância no YouTube: uma análise da produção de conteúdo do canal "Planeta das Gêmeas. In: XXIV Congresso de Ciências da Comunicação na Região Sudeste, Anais...2019.

TUAN, Y. Espaço e lugar: a perspectiva da experiência. São Paulo: DIFEL, 1983. 
TUR-VIÑES， V.; NÚÑEZ-GÓMEZ， P.; GONZÁLEZ-RÍO， M. Menores influyentes en YouTube. Un espacio para la responsabilidad. Revista Latina de Comunicacion Social, v. 73, p. 1211-1230, 28 jun. 2018. Disponível em: <http://www.revistalatinacs.org/073paper/1303/62es.html>.

TUR-VIÑES, V.; NÚÑEZ-GÓMEZ, P.; MARTÍNEZ-PASTOR, E. YouTube, menores y cultura colaborativa. Revisión bibliográfica de la investigación académica". Historia y Comunicación Social, v. 24, n. 1, p. 331-351, 2019.

WARTELLA, E.; JENNINGS, N. Children and Computers: New TechnologyOld Concerns. v. 10, n. 2, p. 31-43, 2000.

WARTELLA, E.; OLIVAREZ, A.; JENNINGS, N. A Criança e a Violência na Televisão nos EUA. In: A CRIANÇA E A VIOLÊNCIA NA MÍDIA. [s.l: s.n.]

WARTOFSKY, M. A Construção do Mundo da Criança e a Construção da Criança do Mundo. In: KOHAN, W. O.; KENNEDY, D. (Ed.). Filosofia e Infância: possibilidades de um encontro. Petrópolis: Vozes, 1999. p. 89-128.

YOUTUBE. Como determinar se o seu conteúdo é para crianças - Ajuda do YouTube. em: <https://support.google.com/youtube/answer/9528076?hl=pt-BR\&authuser=1 >. Acesso em: 20 out. 2020a.

YOUTUBE. Programa de Parcerias do YouTube: visão geral e qualificação Ajuda do YouTube. Disponível em: $<$ https://support.google.com/youtube/answer/72851?hl=ptBR\&ref_topic $=9153826>$. Acesso em: 21 nov. $2020 \mathrm{~b}$. 


\section{Apêndices}

\subsection{Levantamento}

QUANTOS ANOS VOCÊ TEM?

VOCÊ É: ( ) MENINO

( ) MENINA

1) QUAIS TIPOS DE VÍDEOS SÃO SEUS FAVORITOS? (MARQUE COM UM $X$ TODOS OS TIPOS QUE VOCÊ MAIS GOSTA DE ASSISTIR)

( ) VÍDEOS ENGRAÇADOS

( ) VLOGS

( ) VÍDEOS DE GAMEPLAY (JOGOS)

( ) VÍDEOS DE MAQUIAGEM

( ) VÍDEOS DE TERROR

( ) VÍDEOS DE FAÇA VOCÊ MESMO (DIY)

( ) VÍDEOS DE TEATRINHO

( ) VÍDEOS DE BRINQUEDOS

( ) VÍDEOS DE SLIME

( ) VÍDEOS DE DESAFIO

( ) VÍDEOS DE TROLLAGEM

( ) VÍDEOS DE CURIOSIDADES

( ) VÍDEOS DE PARÓDIA

( ) VÍDEOS DE MEMES

( ) VÍDEOS SOBRE SAÚDE, FITNESS,

BEM-ESTAR

( ) VÍDEOS DE TUTORIAL

( ) VÍDEOS DE Q\&A (PERGUNTAS E RESPOSTAS)

( ) VÍDEOS DE PERGUNTAS FREQUENTES

( ) VÍDEOS DE COLABORAÇÃO

( ) VÍDEOS DE TOP 10

( ) VÍDEOS DE FAVORITOS DO MÊS

( ) VÍDEO-AULAS

( ) VÍDEOS DE UNBOXING

( ) VÍDEOS DE REVIEW/RESENHA

( ) VÍDEOS DE REAÇÃO

OUTROS:

2) QUAIS SÃO OS SEUS CANAIS FAVORITOS DO YOUTUBE?

1)

2)

3) 


\subsection{Convite divulgado nas redes sociais para levantamento}

Para quem não sabe, eu sou pedagoga e faço mestrado em educação na PUCRio. Estou fazendo uma pesquisa sobre a relação das crianças com os vídeos a que elas assistem no YouTube. $\rightarrow$ Nesse momento, preciso distribuir meu questionário entre crianças do $3^{\circ}, 4^{\circ}$ e $5^{\circ}$ ano de escolas particulares que atendem classes socioeconômicas altas do município do Rio de Janeiro. EAntes da quarentena eu consegui muitas respostas em uma escola filantrópica que atende classes sociais menos favorecidas, por isso agora peço para que sejam crianças de escolas com esse outro perfil.

O questionário é bem curto, em menos de 5 minutinhos as crianças respondem. Caso vocês conheçam pessoas que tenham crianças nesse perfil, ficaria muito agradecida se puderem compartilhar esse post! Aqui explico rapidamente a proposta:

A primeira parte do questionário é anônima e deve ser respondida pela própria criança. São poucas perguntas sobre os tipos de vídeos e canais preferidos delas. Ao final do questionário, eu pergunto se a criança deseja conversar mais comigo sobre esse assunto. Se ela responder que sim, peço que chame um adulto para poder autorizar a participação e deixar o telefone ou email para que eu possa entrar em contato e marcar a conversa. Não tem problema nenhum se as crianças quiserem responder apenas à primeira parte do questionário, já me ajudarão muito de qualquer forma!

\subsection{Roteiro de Entrevista}

\section{YouTube}

1) Vocês assistem vídeos do YouTube desde que idade?

2) Vocês têm uma conta só de vocês no YouTube? Ou usam a conta de outra pessoa?

3) Vocês preferem assistir YouTube ou televisão? Por quê?

\section{Tipos de vídeos}

4) Quais são os tipos de vídeos que vocês mais gostam de assistir no YouTube? E quais vocês não gostam tanto? Por quê?

5) Como vocês acham vídeos novos pra assistir?

6) Vocês conversam com os amigos sobre os vídeos que assistem? O que? Já começaram a gostar de algum tipo de vídeo por causa da indicação dos amigos? Me dê exemplos.

7) Vocês acham que têm vídeos só para meninas e outros só para meninos? Quais? Exemplos.

8) Vocês assistem vídeos de desafios? Sobre os vídeos de desafios, vocês têm vontade de fazer em casa? Já fizeram algum? E os de trollagem?

9) Tem alguns tipos de vídeos que vocês acham que não seja legal pra idade de vocês? Quais? 


\section{Canais do YouTube}

\section{Agora vamos falar só de canais do YouTube:}

10) Quais canais vocês gostam de assistir no YouTube?

11) Como vocês descobriram esses canais?

12) Por que vocês gostam de assistir os vídeos desses canais?

13) Vocês se identificam com esses youtubers? Em quais aspectos?

14) Vocês acham que aprendem coisas com esses youtubers? O que?

15) Dessas coisas que vocês aprendem, o que vocês consideram bom ou ruim?

16) Acham que ele/ela é um bom exemplo para vocês? Por quê?

17) Tem algo que o youtuber faz que vocês consideram que não seja muito correto? O que? Por quê?

18) Vocês conversam com suas famílias sobre o que vocês assistem no Youtube? Eles conhecem os canais que vocês assistem? O que eles acham?

19) Seus pais ou familiares já reclamaram de vocês assistirem a algum canal? Por qual motivo? Vocês concordam com essas críticas?

20) Se seus pais não gostassem de alguma coisa que o youtuber fez, e não deixassem mais vocês assistirem o canal, o que vocês fariam? (se concordasse que é algo errado e se não concordasse)

21) E seus amigos? Assistem esses canais também? Vocês gostam de conversar sobre isso?

22) Vocês interagem com esses youtubers de alguma forma? Como?

\section{Youtubers mirins}

23) Vocês conhecem canais de youtubers da idade de vocês? O que vocês acham?

24) Vocês sentem falta de algum tipo de conteúdo no Youtube? Qual/is?

25) Vocês já tiveram vontade de serem youtubers? Por quê?

26) Se vocês fossem youtubers, o que teria no canal de vocês? 


\subsection{Convite divulgado nas redes sociais para entrevista}

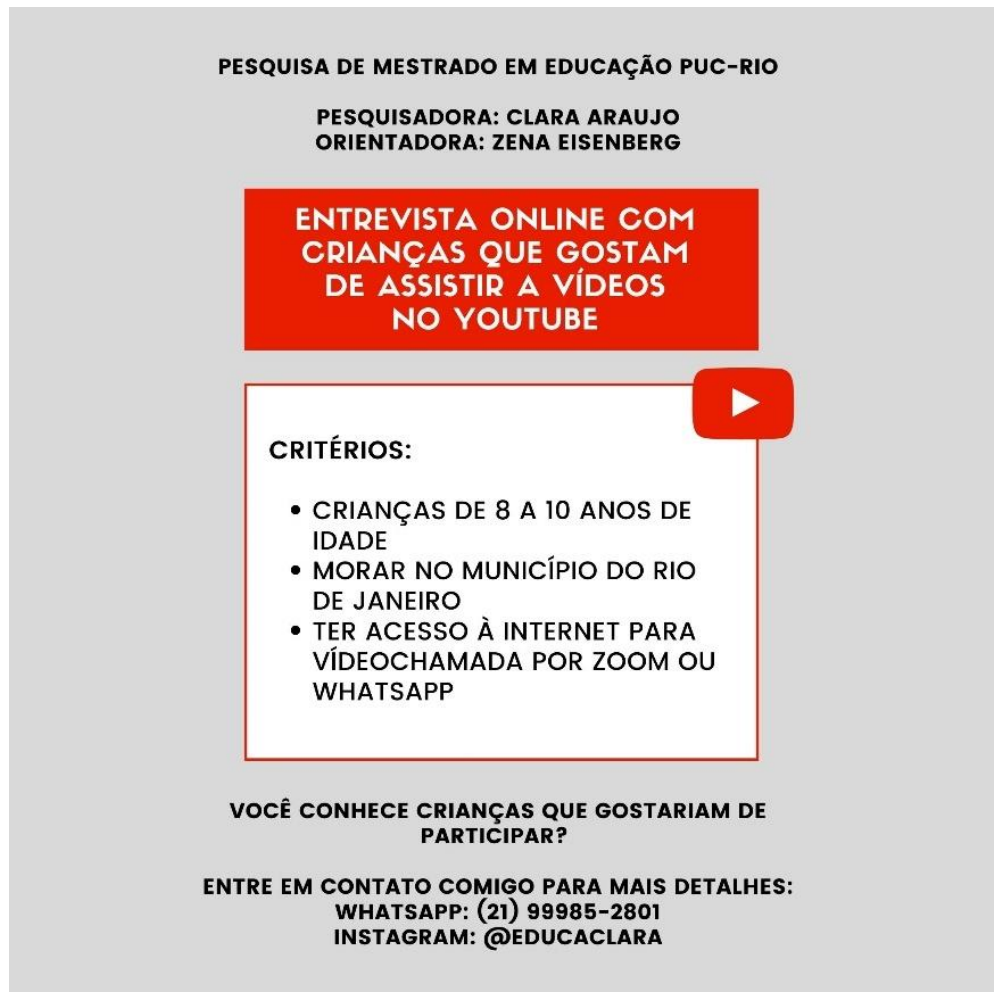

\subsection{Formulário para entrevista}

\section{Pesquisa sobre vídeos e canais a que as crianças gos- tam de assistir no YouTube}

Prezado(a) responsável, meu nome é Clara de Melo Araujo, sou mestranda em Educação na PUC-Rio e estou fazendo uma pesquisa sobre a relação das crianças com os conteúdos a que elas assistem no YouTube.

Seu filho(a) se interessou em conversar mais comigo sobre os canais e vídeos a que ele(a) assiste na plataforma. A proposta seria fazer entrevistas individuais ou coletivas com crianças dessa mesma faixa etária em videochamada via zoom ou whatsapp para conversarmos um pouco mais sobre o tema. Se você desejar, pode estar presente durante a conversa. Caso você esteja de acordo, por favor, leia o Termo de Consentimento na questão abaixo e depois selecione a opção concordando em participar dessa etapa.

Ressalto que minha pesquisa foi aprovada pela Câmara de Ética em Pesquisa da PUC-Rio, e que levará em consideração os princípios e cuidados éticos necessários nas pesquisas com humanos, em especial com as crianças, incluindo o anonimato das crianças participantes. Caso deseje saber mais sobre a pesquisa ou esclarecer 
qualquer dúvida, sinta-se à vontade para entrar em contato. Telefone: (21) 99985-

2801 // Email: claramelo@uol.com.br ou zwe@puc-rio.br (Orientadora: Zena Eisenberg).

\section{*Obrigatório}

1. Após ler o Termo de Consentimento no link, clique na caixa abaixo autorizando seu filho(a) a participar da pesquisa.

https://drive.google.com/file/d/1ITihQf78PfLSMXcjirfVJbpgSR43zPSt/view?usp=sharing

( ) Autorizo

( ) Não Autorizo

2. Seu nome *

3. Nome da criança *

4. Quantos anos a criança tem? *

() 8 anos
( ) 9 anos
( ) 10 anos

5. Faixa de renda mensal da família *

( ) Até 1 salário mínimo (até $\mathrm{R} \$ 1045,00$ ).

( ) De 1 a 3 salários mínimos (de $R \$ 1045,01$ até $R \$ 3135,00$ ).

( ) De 3 a 6 salários mínimos (de $R \$ 3135,01$ até $R \$ 6270,00$ ).

( ) De 6 a 9 salários mínimos (de $\mathrm{R} \$ 6270,01$ até $\mathrm{R} \$ 9405,00$ ).

( ) Acima de 10 salários mínimos

6. Quais dias/horários a criança tem disponíveis para a entrevista? *

Pode ser dia de semana ou final de semana. Dependendo da disponibilidade, vou agrupar com outras crianças ou realizar a entrevista individualmente.

\subsection{Termo de Consentimento Livre e Esclarecido}

Pontifícia Universidade Católica $_{\text {a }}$ DO RIO DE JANEIRO TERMO DE CONSENTIMENTO LIVRE E ESCLARECIDO | PAIS E RES-
PONSÁVEIS

Prezado/a:

Viemos, por meio deste, convidar seu filho/sua filha a participar da pesquisa apresentada a seguir. 
Pesquisa: O que as crianças aprendem com seus canais favoritos do YouTube?

\section{Pesquisador Responsável:}

Clara de Melo Araujo | claramelo@uol.com.br | Tel. (21) 99985-2801

Justificativas: Ouvimos reclamações sobre o tempo que é gasto pelas crianças diante das telas e os possíveis efeitos que essa exposição precoce pode ter. Entretanto, pouco se discute sobre o conteúdo que está sendo visto pelas crianças e o que elas podem aprender a partir dele - seja algo positivo ou não. Assim, a pesquisa se justifica a fim de potencializar o debate, para realmente compreendermos as potências e limites dos vídeos que as crianças estão assistindo, visando sempre uma infância de qualidade.

\section{Objetivos:}

1) Conhecer quais são os canais mais assistidos pelas crianças e qual o tipo de conteúdo que elas mais gostam no YouTube;

2) Analisar o conteúdo dos canais elencados para entender o que as crianças podem estar aprendendo sobre hábitos e valores a partir dos vídeos postados neles;

3) Ouvir o que as crianças têm a dizer sobre o que estão aprendendo com tais conteúdos.

Metodologia: Os participantes da pesquisa serão crianças de 8 a 10 anos de escolas públicas e particulares da cidade do Rio de Janeiro.

A proposta de metodologia pode ser dividida em 3 etapas:

\section{Levantamento dos canais do YouTube mais assistidos pelas crianças} por meio de questionário: Será utilizada uma ficha que conta com duas perguntas que serão respondidas pelas crianças de forma anônima. Essas perguntas buscam fazer um levantamento inicial dos canais e tipos de vídeos que as crianças mais assistem no YouTube. Esse levantamento será distribuído para as turmas com crianças de 8 a 10 anos de 8 escolas diferentes, sendo 4 da rede particular e 4 da rede pública. Depois de uma análise, serão selecionados os 4 canais mais frequentemente citados pelas crianças de uma dada escola. Com essa informação em mãos, visitarei de novo quatro das escolas para realizar entrevistas coletivas com as crianças que elegeram esses canais mais frequentemente citados como seus preferidos.

II. Entrevistas coletivas com algumas crianças sobre o que elas pensam desses conteúdos a que assistem: As entrevistas coletivas serão realizadas com grupos de 4 ou 5 crianças de 8 a 10 anos de idade que assistem aos canais que foram mais citados nas escolas. Dessa forma, serão feitas 4 entrevistas, sendo cada uma especificamente sobre um dos 4 canais. Eu entrarei nas salas de aula que sei que têm crianças que marcaram esses canais como favoritos e perguntarei quais desejam participar da entrevista coletiva. As que desejarem participar, receberão esse Termo de Consentimento Livre e Esclarecido. Com seu consentimento, as crianças preencherão o Termo de Assentimento de modo a garantir que entenderam os procedimentos e objetivos da pesquisa e que estão de acordo em participar. Somente então, poderei marcar na escola, no horário do intervalo das aulas, a entrevista coletiva com as crianças que gostam de um mesmo canal. 
III. Análise de conteúdo dos canais mais citados pelas crianças: Os canais mais assistidos, que serão base para as entrevistas coletivas, terão seus conteúdos analisados. Pela impossibilidade de analisar todos os vídeos de um canal, serão selecionados os 5 vídeos mais visualizados nos últimos 6 meses de canal, que tenham como duração mínima 10 minutos. Serão criadas categorias de análise com base no que a literatura aponta como conteúdo online positivo e também no que as crianças trouxerem nas entrevistas coletivas.

O seu consentimento está sendo solicitado apenas para a participação na $2^{\mathrm{a}}$ etapa da pesquisa, que será realizada na escola onde seu filho estuda, com mais 3 ou 4 alunos de 8 a 10 anos. Essa entrevista será realizada no horário do intervalo das aulas e será vídeo-gravada para posterior análise. Apenas a autora e a orientadora da pesquisa terão acesso às gravações. Elas não serão divulgadas em hipótese alguma fora desse contexto. O material gravado e todos os dados coletados têm garantia de confidencialidade e sigilo. Esse material ficará guardado de forma segura com a pesquisadora pelo prazo mínimo de cinco anos.

Riscos e Benefícios: Há possibilidade de algum tipo de constrangimento ao abordar temas relacionados a conteúdos inadequados para a idade das crianças nos vídeos do YouTube. No entanto, todos os procedimentos levarão este risco em conta, respeitando os sujeitos envolvidos. Caso alguma criança se sinta constrangida ou com vergonha, conversaremos com ela, e caso seja do seu desejo, ela poderá parar de participar da pesquisa imediatamente. A entrevista coletiva também apresenta risco de gerar conflitos no grupo, uma vez que uma criança conhecerá a resposta da outra e pode não gostar ou não concordar. Nesse caso, novamente vamos mediar e conversar com as crianças, tentando deixá-las confortáveis para expressar suas opiniões e sempre deixando claro que elas podem parar de participar da pesquisa caso queiram. Prevemos, no entanto, que a experiência será prazerosa para os participantes já que estarão discutindo algo que costumam fazer em momentos de lazer e terão a chance de compartilhar sua visão com outras crianças de idades parecidas. Além disso, a pesquisa poderá contribuir bastante para se pensar na criação futura de conteúdos positivos para as crianças e ampliar a discussão dessa temática.

Em caso de qualquer dúvida sobre a pesquisa, você poderá, a qualquer momento, entrar em contato com a professora Dr. ${ }^{a}$ Zena Winona Eisenberg - seus contatos são: (21) 3527-2714 (PUC-Rio), (21) 99640-4038 (celular) ou ainda pelo e-mail zwe@ puc-rio.br. E, com a pesquisadora Clara de Melo Araujo, pelo telefone (21) 99985-2801, pelo e-mail claramelo@uol.com.br ou no Programa de Pós-Graduação em Educação da PUC-Rio, localizado Rua Marquês de São Vicente, 225, Gávea Rio de Janeiro, RJ - Brasil, Cep: 22451-900 - Cx. Postal: 38097 | Telefone: (55 21) 3527-1001 Caso você tenha dificuldade para entrar em contato com os pesquisadores responsáveis, comunique o fato à Câmara de Ética em Pesquisa da PUC-Rio, que funciona na Rua Marquês de São Vicente, 225 - Edifício Kennedy, $2^{\circ}$ andar. Gávea, Rio de Janeiro, RJ. CEP: 22453-900. Fone: (21) 3527-1618.

$\mathrm{Eu}$,

lho/minha filha, de maneira voluntária, livre e esclarecida, autorizo meu fiparticipar desta pesquisa. Estou ciente dos objetivos do estudo, dos procedimentos 
metodológicos, dos possíveis desconfortos com o tema, das garantias de confidencialidade e da possibilidade de esclarecimentos permanentes sobre os mesmos. Fui informado(a) de que se trata de pesquisa em andamento no Programa de Pós-Graduação em Educação da PUC-Rio. Está claro que minha autorização é isenta de despesas e que a imagem e nome do meu filho/minha filha não serão publicados sem minha prévia autorização por escrito. Estou de acordo com a vídeo-gravação da entrevista coletiva a ser cedida para fins de registros acadêmicos. Estou ciente de que, em qualquer fase da pesquisa, tenho a liberdade de recusar a minha autorização ou retirar meu consentimento, sem nenhuma penalização ou prejuízo que possam ser imputados ao meu filho/minha filha.

[assinatura do responsável]

Clara de Melo Araujo, pesquisadora

Grau de parentesco:

Nome completo:

E-mail:

Tel.

Identificação (RG):

| Rio de Janeiro

de de

OBS.: Este termo é assinado em 2 vias, uma do/a responsável e outra para os arquivos do pesquisador.

\subsection{Termo de Assentimento Livre e Esclarecido}

Roteiro que utilizei ao início da entrevista:

"Olá! Meu nome é Clara. Estou fazendo esse trabalho para o meu mestrado, que é uma coisa que fazemos depois da faculdade. No mestrado, podemos escolher o tema que quisermos para pesquisar. Eu escolhi o tema do YouTube, e estou entrevistando várias crianças sobre isso. Seu responsável já autorizou você a participar dessa entrevista. Você gostaria de participar? (...) Eu preciso gravar a entrevista para que depois eu possa lembrar de quem disse cada coisa e escrever meu trabalho. Ninguém vai ver essa gravação, apenas eu. Você autoriza que eu grave a imagem e o áudio da nossa conversa? (...) Você pode tirar todas as suas dúvidas e a qualquer momento pode interromper a entrevista, tudo bem?" 


\section{Anexos}

\subsection{Parecer da Secretaria Municipal de Educação do Rio de Ja- neiro}

\begin{tabular}{|l|l|}
\hline Processo $n^{\circ} 07 / 002.006 / 2020$ \\
\hline Data: $04 / 03 / 2020$ & Fls.: \\
\hline Rubrica: \\
\hline
\end{tabular}

À E/SUBE, segue o parecer técnico com relaçăo à realizaçāo da pesquisa acadêmica ora proposta por Clara de Melo Araújo, Mestranda do Curso de Mestrado em Educação Brasileira do Programa de Pós-Graduação em Educação da PUC/RJ.

Título da Pesquisa: "O que as crianças aprendem com seus canais favoritos do Youtube?"

Pesquisadora: Clara de Melo Araújo

Identificação da Instituição: PUC/RJ

Linha de PesquisalÁrea de conhecimento: Programa de Pós-Graduaçāo em Educação/Mestrado em Educação Brasileira

Orientador: Zena Eisenberg

A pesquisa intitulada "O que as crianças aprendem com seus canais favoritos do Youtube?" tem por finalidade conhecer quais são os canais mais assistidos pelas crianças e qual o conteúdo que eles mais gostam no Youtube, bem como analisar o conteúdo dos canais elencados para entender o que as crianças podem estar aprendendo sobre hábitos e valores a partir dos vídeos postados neles, e por fim, ouvir o que as crianças têm a dizer sobre o que estão aprendendo com tais conteúdos.

Como metodologia proposta, a pesquisadora prevê uma análise qualitativa realizada em três etapas, com grupos de alunos de 8 a 10 anos de escolas públicas da rede municipal e particulares do Rio de Janeiro. Na primeira etapa será realizado um levantamento dos canais do Youtube mais assistidos pelas crianças. Posteriormente será realizada uma entrevista coletiva com algumas crianças para saber o que elas acham do conteúdo que assistem. E finalmente será realizada uma análise, de acordo com os referenciais teóricos estudados, dos conteúdos dos canais mais citados pelas crianças. Sugerimos que os objetivos desta pesquisa sejam destacados do conteúdo da introduçāo.

Solicitamos que sejam informados os nomes das unidades escolares onde será realizada a pesquisa, assim que as anuências das escolas estiverem prontas, e quantos alunos participarāo desta pesquisa e quais os critérios para seleção desses alunos. 
Solicitamos ainda que seja esclarecida qual a base de dados para a seleção das escolas pelo nível socioeconômico.

Levando em consideração que a Organização Mundial de Saúde (OMS) declarou, em 11 de março de 2020, que a disseminação comunitária do COVID-19 em todos os Continentes caracteriza pandemia e que estudos recentes demostram a eficácia das medidas de afastamento social precoce para restringir a disseminação do COVID-19, as Unidades Escolares encontram-se temporariamente fechadas. Por isso, aguardamos a publicação do Plano de Retomada publicado em Diário Oficial do Município do Rio de Janeiro (Ano XXXIV | No 58 | Terça-feira, 2 de Junho de 2020 | $2^{\text {a }}$ Edição) e a chegada da fase 2 para solicitarmos a readequação do cronograma de pesquisa, visto o panorama descrito em que há previsão de abertura gradual das unidades escolares a partir da fase 3 .

Considerando os elementos expostos acima, entendemos que a pesquisa é relevante e, mediante ao cumprimento das exigências, será feita nova validação pela Gerência de Fomento à Pesquisa e Avaliação Externa.

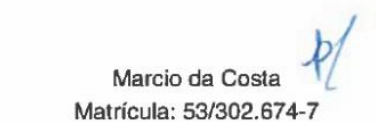

Matrícula: 53/302.674-7

Diretor Geral da Escola Paulo Freire

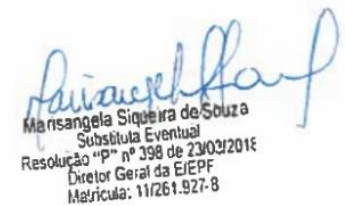




\subsection{Parecer da Câmara de Ética em Pesquisa da PUC-Rio}

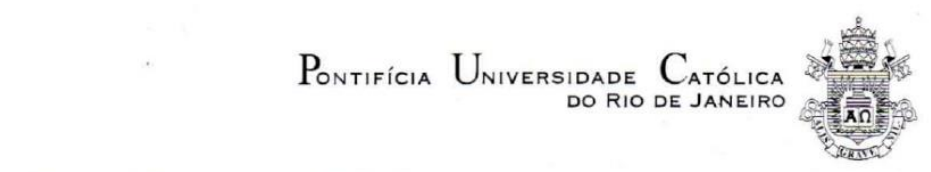

CÂMARA DE ÉTICA EM PESQUISA DA PUC-Rio

Parecer da Comissão de Ética em Pesquisa da PUC-Rio 118/2020 - Protocolo 127/2019

A Câmara de Ética em Pesquisa da PUC-Rio foi constituida como uma Câmara especifica do Conselho de Ensino e Pesquisa conforme decisão deste órgão colegiado com atribuição de avaliar projetos de pesquisa do ponto de vista de suas implicações éticas.

Identificação:

Título: "O que as crianças aprendem com seus canais favoritos do YouTube" (Departamento de Educação da PUC-Rio)

Autora: Clara de Melo Araújo (Mestranda do Departamento de Educação da PUC-Rio).

Orientadora: Zena Eisenberg (Professora do Departamento de Educação da PUC-Rio).

Apresentação: A pesquisa tem por objetivos: I. Conhecer quais são os canais mais assistidos pelas crianças e qual tipo de conteúdo que elas mais gostam no YouTube; II. Analisar o conteúdo dos canais crianças e qual tipo de conteúdo que elas mais gostam no YouTube; Il. Analisar o conteúdo dos canais dos videos postados neles; III. Ouvir o que as crianças têm a dizer sobre o que estão aprendendo com dos vídeos postados neles; III. Ouvir o que as crianças têm a dizer sobre o que estão aprendendo com
tais conteúdos. Prevê abordar crianças de 8 a 10 anos de oito escolas diferentes, sendo quatro da rede particular e quatro da rede pública ( $2^{\mathrm{a}} \mathrm{CRE}$ - Coordenadoria Regional de Educação do municipio do Rio de Janeiro) com duas de cada com o público predominantemente de classe média alta e duas com crianças de classes mais baixas. Utilizará questionário e entrevista coletiva junto às crianças participantes do estudo.

Aspectos éticos: O projeto, o Termo de Consentimento Livre e Esclarecido e o Termo de Assentimento Livre e Esclarecido apresentados estão de acordo com os principios e valores do Marco Referencial, Estatuto e Regimento da Universidade no que se refere às responsabilidades de seu corpo docente e discente. Os Termos expōem com clareza os objetivos da pesquisa e os procedimentos a serem seguidos. Garantem o sigilo e a confidencialidade dos dados coletados Informam sobre a possibilidade de interrupção na pesquisa sem aplicação de qualquer penalidade ou constrangimento.

Parecer: Aprovado

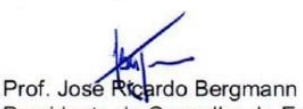

Presidente do Conselho de Ensino e Pesquisa da PUC-Rio

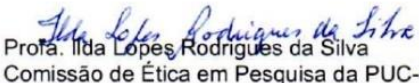

Rio de Janeiro, 05 de dezembro de 2019

Vice-Reitoria para Assuntos Acadênicos Câmara de Ética em Pesquisa da PUC-Rio - CEPq/PUC-Rio Rua Marquês de São Vicente, 225 - Gávea - 22453-900
Rio de Janeiro - RJ - Tel. (021) 3527-1612 3527-1618 Rio de Janeiro - RJ - Tel. (021) 3527-1612/3527-1618 